NBER WORKING PAPER SERIES

\title{
THE MODERN HISTORY OF EXCHANGE RATE ARRANGEMENTS: A REINTERPRETATION
}

\author{
Carmen M. Reinhart \\ Kenneth S. Rogoff \\ Working Paper 8963 \\ http://www.nber.org/papers/w8963
NATIONAL BUREAU OF ECONOMIC RESEARCH
1050 Massachusetts Avenue
Cambridge, MA 02138
June 2002

\begin{abstract}
The authors wish to thank Vincent Reinhart and Miguel Savastano and participants at Harvard's Canada-US Economic and Monetary Integration Conference for useful comments and suggestions and Kenichiro Kashiwase, Daouda Sembene, and Ioannis Tokatlidis for excellent research assistance. The views presented in this paper are those of the authors and are not necessarily those of the International Monetary Fund. This work was largely undertaken while the authors were professors at the University of Maryland and Harvard University, respectively. The views expressed herein are those of the authors and not necessarily those of the National Bureau of Economic Research or the International Monetary Fund.
\end{abstract}

(C) 2002 by Carmen M. Reinhart and Kenneth S. Rogoff. All rights reserved. Short sections of text, not to exceed two paragraphs, may be quoted without explicit permission provided that full credit, including (C) notice, is given to the source. 
The Modern History of Exchange Rate Arrangements: A Reinterpretation

Carmen M. Reinhart and Kenneth S. Rogoff

NBER Working Paper No. 8963

June 2002

JEL No. F30, F31, F41

\begin{abstract}
We develop a novel system of re-classifying historical exchange rate regimes. One difference between our study and previous classification efforts is that we employ an extensive data base on market-determined parallel exchange rates. Our "natural" classification algorithm leads to a stark reassessment of the post-war history of exchange rate arrangements. When the official categorization is a form of peg, roughly half the time our classification reveals the true underlying monetary regime to be something radically different, often a variant of a float. Conversely, when official classification is floating, our scheme routinely suggests that the reality was a form of de facto peg. Our new classification scheme points to a complete rethinking of economic performance under alternative exchange rate regimes. Indeed, the breakup of Bretton Woods had a far less dramatic impact on most exchange rate regimes than is popularly believed. Also, contrary to an influential empirical literature, our evidence suggests that exchange rate arraignments may be quite important for growth, trade and inflation. Our newly compiled monthly data set on market-determined exchange rates goes back to 1946 for 153 countries.
\end{abstract}

Carmen M. Reinhart

Research Department

Room 10-700H

International Monetary Fund

700 19th Street, NW

Washington, DC 20431

and NBER

creinhart@imf.org
Kenneth S. Rogoff

Research Department

International Monetary Fund

700 19th Street, NW

Washington, DC 20431

and NBER

krogoff@imf.org 


\section{Introduction}

Contemporary thinking on the costs and benefits of exchange rate flexibility is heavily influenced by the large number of studies on the empirical differences in growth, trade, inflation, business cycles, and commodity price behavior across different exchange rate arrangements. These include the influential work of Baxter and Stockman (1989) and Flood and Rose (1995), both of whom failed to detect any significant difference across fixed and floating rates, except for the volatility of real exchange rates that Mussa (1986) had already noted. Nearly all such studies have relied on the official or "standard" classification published in the IMF's Annual Report on Exchange Rate Arrangements and Exchange Restrictions which, until recently, asked member states to self-declare their arrangement as belonging to one of four categories (fixed, limited flexibility, managed floating, and independently floating). Yet, a closer reading of the experience suggests that these official classifications often fail to describe actual country practice, implying that the gap between de facto and de jure can be vast. A few previous studies have attempted to either extend the four-way official classification into a more informative meaningful taxonomy (see Gosh et. al., 1997), or have relied on purely statistical methods to regroup country practices (see, Levy-Yeyati and Sturzenegger, 2002). ${ }^{1}$ The Fund, recognizing the limitations of its former strategy, significantly revised and upgraded the standard official approach toward classifying exchange rate arrangements in 1997, though it did not re-evaluate its historical classification after the fact. Notably, all previous approaches to exchange rate regime classification,

\footnotetext{
${ }^{1}$ See also Masson (2000) and Glick (2001).
} 
whether or not they accept the country's declared regime, have been based almost solely on official exchange rate series.

One problem with the pre-1997 official classification that has received substantial attention in the recent literature is the frequency of episodes where the regime is classified as floating (independently or managed) when, in effect, the country had a de facto peg or crawling peg. ${ }^{2}$ However, a less well known but equally serious problem, shared even by the small number of earlier efforts to reclassify regimes, is that the officially-reported exchange rate itself is often profoundly misleading. Over the course of post-World War II history, virtually every country has relied, at one time or another, on capital controls and/or multiple exchange rate systems. ${ }^{3}$ By failing to look at market-determined exchange rates, one often gets a false picture of the underlying monetary policy and the ability of the economy to adjust imbalances. When there are dual or parallel markets, a regime that is officially labeled a peg might easily turn out to be a de facto float or a crawling band. As an illustration suppose, for example, that the parallel market rate undergoes sustained and significant depreciation but the official rate remains fixed. (Over the broad sweep of post-war history, we find this a common occurrence.) Then the underlying monetary policy is inflationary, but the effects on the official nominal exchange rate are effectively masked-at least in the short run--by an ever-increasing tariff. By far the most common outcome in these circumstances is that the

\footnotetext{
${ }^{2}$ See Calvo and Reinhart (2002), Levy-Yeyati and Sturzenegger (2002), and Wickham (2002).

${ }^{3}$ Edwards (1989) stresses the inadequacy of official exchange rate data for the many Latin American economies with multiple exchange rates.
} 
official rate is ultimately devalued, thus validating what had already transpired in the free market.

Thus when there are dual markets, it is not sufficient to just discard the official exchange rate classification. One very often also has to discard the official rate, which can be meaningless and far removed from the rate at which transactions take place. Another difference from other studies that have tackled the regime classification issue is that our approach relies on extensive historical chronologies that allow us to identify when dual or multiple rates are in place or when parallel markets are active. In the vast majority of these cases, our data set contains monthly data on dual/parallel market exchange rates from 1946 through 1998, and we use these data to assess whether, from a monetary perspective, the true de facto regime corresponds to the stated de jure regime. Very often-roughly half the time for official pegs over the post-1970 period-we find that dual/parallel rates have been used as a form of back-door floating. ${ }^{4}$ Lastly, we rely on a large battery of descriptive statistics to classify exchange rate arrangements into as many as 15 categories. We argue that both pieces of information-historical chronologies and data on market-determined exchange rates--are essential to any meaningful classification algorithm.

We note also that the IMF's monthly data on exchange rates — which only includes the official rate - currently begin in 1957, whereas ours begin in 1946. Our analysis is extremely comprehensive, covering 153 countries. Since exchange rate regimes are often

\footnotetext{
${ }^{4}$ The IMF data for official exchange rates begins on January 1957 for most countries. We also compiled data on official exchange rates from 1946 through 1957; see appendix.
} 
mixed within a given year, our methodology captures regimes changes by month; all previous approaches have used only annual classifications. ${ }^{5}$

The highlights of our findings can be summarized as follows:

First, dual or multiple rates, and/or parallel markets were far more commonplace that is commonly thought. ${ }^{6}$ In 1950,45 percent of the countries in our sample had dual rates, not to mention many more that had thriving illegal parallel markets! Among the industrialized economies, dual or multiple rates were the norm in the 1940s and the 1950 s and, in some cases, lasted until much later. Those countries that clung to dual or multiple exchange rates were important actors on the world stage and included the United Kingdom in the 1970s, Italy in the 1980s, and Belgium and Luxembourg until 1990. ${ }^{7}$ Among developing countries such practices remained relatively commonplace through the 1980s. Going back as recently as 1980, 32 percent of countries had dual rates. In the 1990s, the number still stood at approximately 20 percent, including some of the largest emerging markets.

Second, when one uses market-determined rates in place of official rates, the history of exchange rate policy suddenly begins to look very different. In particular, it becomes obvious that de facto floating was not uncommon during the so-called Bretton Woods era of "pegged" exchange rates. Indeed, for many countries, it is difficult to detect any change in exchange rate behavior between the two periods (provided one focuses on market-determined

\footnotetext{
${ }^{5}$ See Côté (1994) for a survey of this literature.

${ }^{6}$ When we refer multiple exchange rates in this context, we are focusing on the cases where one or more of the rates was market-determined. This is very different from the cases where the multiple official rates are all fixed and simply act as a differential tax on a variety of transactions.

${ }^{7}$ Of course, over the more recent period the differences in rates was relatively trivial.
} 
rates). The main impact of the dissolution of Bretton Woods was on G-3 currencies, the US dollar, the Yen, and the mark. Remarkably, in our "natural" classification scheme, we find that for about 45 percent of the time official pegs are better characterized as managed or freely floating arrangements, or limited flexibility. Indeed, we find that very often, an official "peg” masks an underlying 12-month inflation rate greater than 40 percent. Thus, nearly half of the official "pegs" turn out to have exhibited far more exchange rate flexibility than was reported to the IMF. Conversely, many "floats" of the post-1980s turn out to be (de facto) pegs, crawling pegs, or very narrow bands (often narrower than Bretton Woods period). Of countries that are listed in the standard classification as managed floating, 53 percent turned out to have de facto pegs, crawls or narrow bands to some anchor currency.

Third, next to pegs (which account for 33 percent of the observations during 19702001, according to our new classification scheme) the most popular exchange rate regime over modern history has been the crawling peg or narrow crawling band, which account for over 26 percent of the observations. During 1990 to 2001, this is the most common type of arrangement in emerging Asia and Western Hemisphere (excluding Canada and the United States), making up for about 36 and 42 percent of the observations, respectively.

Fourth, in our taxonomy, the extreme macroeconomic distresses associated with inflation over $40 \%$ per annum—we term the underlying exchange rate regimes "freely falling"-are not uncommon. In our sample, about $12^{1 / 2}$ percent of the observations are in the freely falling category-which is to say that "freely falling" is about three times as common as "freely floating", which accounts for only $4 \frac{1}{2}$ percent of the total observations. (In the official classification, freely floating accounts for over 30 percent of observations in the past decade, more than three times our estimate.) Our new freely falling classification 
makes up for 22 and 37 percent of the observations in Africa and Western Hemisphere (excluding Canada and the United States) during 1970-2001..$^{8}$ In the 1990s, freely falling accounted for 41 percent of the observations for the transition economies. Given the distortions introduced when inflation rises to 40 percent and beyond, any fixed versus flexible exchange rate regime comparisons that do not break out the freely falling episodes are meaningless, as shall confirm.

In light of the evidence we collect, we conjecture that the surprising and provocative results in Baxter and Stockman (1989) and Flood and Rose (1995) — that there are no significant differences in business cycles across exchange arrangements - may owe to the fact that the official historical groupings of exchange rates are misleading. ${ }^{9}$ Similar statements could be made about the literature that has concluded that exchange rate volatility has little impact on trade, as all studies relied exclusively on the official exchange rate. At one time or another, in every region of the world, parallel/dual markets have been commonplace.

The paper proceeds as follows. In the next section, we briefly describe the evolution of the official standard annual classification scheme, that has served as the basis for so many studies. Unlike our classification, which is by month, the official classification imposes the same regime on the entire year. In Section III, we sketch our methodology for re-classifying exchange rate arrangements with details provided in an Appendix. Our approach recognizes

\footnotetext{
${ }^{8}$ We also include in the freely falling category the first six months following an exchange rate crisis (see Appendix II for definitions), but only for those cases where the crisis marked a transition from a peg or quasipeg to a managed or independent float.

9 Indeed, in light of our results, it is difficult to discern the "puzzle" that recent research is still trying to explain as in Dedola and Leduc (2001).
} 
that an exchange rate regime is difficult to ascertain from one month's or even one-year's worth of data. Section IV compares our results to the "official history" and provides examples of how our reclassification of exchange rate arrangements may reshape the some of the existing evidence on the links between exchange rates and various facets of economic activity. The final section discusses the scope for future research, while an Appendix provides the detailed country exchange rate chronologies that underpin our analysis. Our conclusions issue a call for rethinking how the profession should look at the impact of exchange rate regimes, both at a theoretical and at an empirical level.

\section{The Standard Classification}

Classification schemes, for anything, have always been controversial. Dating back to Aristotle, there arose two kinds of classificatory schemes for animals and plants, the socalled "artificial" and "natural" systems. Artificial systems placed organic species into wellmarked groups, using a few, sometimes even a single, characteristic for the purposes of classification. Natural systems, on the other hand, aimed to bring the diverse organic species into natural families, in which there was a continuity of creatures. ${ }^{10}$ The standard official classification prior to 1997, as described in various issues of the IMF's Annual Report on Exchange Rate Arrangements and Exchange Rate Restrictions, would seem to fall squarely into the "artificial" system category. As shown in Table 1, initially there were only two buckets, par (fixed) and "other". Later, the classification expanded to three, then four, buckets. The four-bucket classification that prevailed through most of the 1980s and 1990s

\footnotetext{
${ }^{10}$ The French Naturalists of the $18^{\text {th }}$ century were the strongest advocates of the "natural" classification scheme, as explained in Mason (1962).
} 
consisted of peg, limited flexibility, more flexible arrangements, and independently

floating. ${ }^{11}$ Aside from the small number of buckets, the pre-1997 official categorization was also "artificial" — in the sense of Aristotle — in that it relied exclusively on a single piece of information; namely it took at face value whatever each government declared its exchange rate regime to be in any given year. The post-1997 system, though dramatically improved, is still based mainly on the official rate.

\footnotetext{
${ }^{11}$ In practice, limited flexibility has, almost exclusively, been used to classify European countries (prior to the monetary union) with exchange rate arrangements vis-à-vis one another (i.e., the Snake, the Exchange Rate Mechanism, etc.).
} 
Table 1. Evolution of the Fund's "Exchange Arrangements and Restrictions" the Categories for the Annual Classification of Exchange Rate Regimes

\section{Volumes 1950-1973}

1. Par value or central rate exists--Par value of central rate applied

2. Effective rate other than par value or central rate applicable to all or most transactions:

fixed rate or fluctuating rate

Volume 1974, (no mention of par values)

1. Exchange rate maintained within relatively narrow margins in terms of:

US Dollar, Sterling, French Franc, group of currencies, and average of exchange rates of main trading partners.

2. Exchange rate not maintained within relatively narrow margins

\section{Volumes 1975-1978}

1. Exchange rate maintained within relatively narrow margins in terms of:

US Dollar, Sterling, French Franc, South African Rand or Spanish Peseta, group of currencies (under mutual intervention arrangements), and composite of currencies.

2. Exchange rate not maintained within narrow margins

\section{Volumes 1979-1982}

1. Exchange rate maintained within relatively narrow margins in terms of

US Dollar, Sterling, French Franc, Australian Dollar, Portuguese Escudo, South African Rand or Spanish peseta, a group of currencies (under mutual intervention arrangements), a composite of currencies, and a set of indicators.

2. Exchange rate not maintained within relatively narrow margins

\section{Volumes 1983-1996}

Exchange rate determined on the basis of :

1. a peg to: the US Dollar, Sterling, the French Franc, other currencies, and composite of currencies

2. limited flexibility with respect to: a single currency, cooperative arrangement

3. More flexible arrangements: adjusted according to a set of indicators, other managed floating, and

4. independently floating.

\section{Volumes 1997-1998}

1. Pegged to: single currency, composite of currencies

2. Flexibility limited

3. Managed floating

4. Independent floating

\section{Volumes 1999-2001}

1. Exchange arrangement with no separate legal tender

2. Currency board arrangement

3. Conventional pegged arrangement

4. Pegged exchange rate within horizontal bands

5. Crawling peg

6. Crawling band

7. Managed floating with no pre-announced path for the exchange rate

8. Independently floating

Sources: International Monetary Fund, Annual Report on Exchange Restrictions, 1950-1978 and Annual Report on Exchange Arrangements and Exchange Restrictions, 1970-2001. 
The critical importance of taking into account dual/parallel rates can be seen in Chart 1, which gives the distribution of regimes, with and without stripping out cases of dual/parallel markets. The light bars are the official classification; the dark bars separate out dual markets. ${ }^{12}$ Note, for example, that according to the official classification, pegs reigned supreme in the early 1970 s, accounting for over 90 percent of all exchange rate arrangements. But, in fact, over half of these "pegs" masked dual/parallel markets that, as we shall, quite often exhibited quite different behavior.

\section{The "Natural" Classification Code: A Guide}

In contrast to the "artificial" official classification of exchange rate arrangements, we would describe our classification scheme as a "natural" system. Our algorithm relies on a broad variety of descriptive statistics and chronologies, and we group episodes into a much finer grid of regimes, rather than just three or four buckets. The most important new piece of information we bring to bear, of course, is our extensive data series on market-determined dual or parallel rates. The data, its sources, and country coverage are described in Appendix I, while the chronologies that map the history of exchange rate arrangements for each country are reported in Appendix III. To verify and classify regimes, we also rely on a variety of descriptive statistics based on exchange rate and inflation data from 1946 onwards; these statistics and how they are used are described in detail in Appendix II.

\footnotetext{
${ }^{12}$ In Chart I, the dark bars treat dual rates separately, the unified rate regimes are classified according to our "natural algorithm," discussed below.
} 


\section{The algorithm}

Figure 1 is a schematic summarizing our natural classification algorithm. First, we use the chronologies (see Appendix III) to sort out for separate treatment countries with either official dual or multiple rates or active parallel (black) markets. Second, if there is no dual or black market, we check to see if there is an official pre-announced arrangement, such a peg or band, etc. If there is, we examine summary statistics to verify the announced regime, going forward from the date of the announcement. If the regime is verified (i.e., exchange rate behavior accords with the pre-announced policy), it is then classified accordingly as a peg, crawling peg, etc. If the announcement fails verification (which is the most common outcome), we then seek a de facto statistical classification using the algorithm described below, and discussed in greater detail in Appendix II.

Third, if there is no pre-announced path for the exchange rate, or the announced regime fails to be verified by the data and the twelve-month rate of inflation is below 40 percent, we classify the regime on the basis of actual exchange rate behavior. 


\section{Figure 1. A Natural Exchange Rate Classification System}

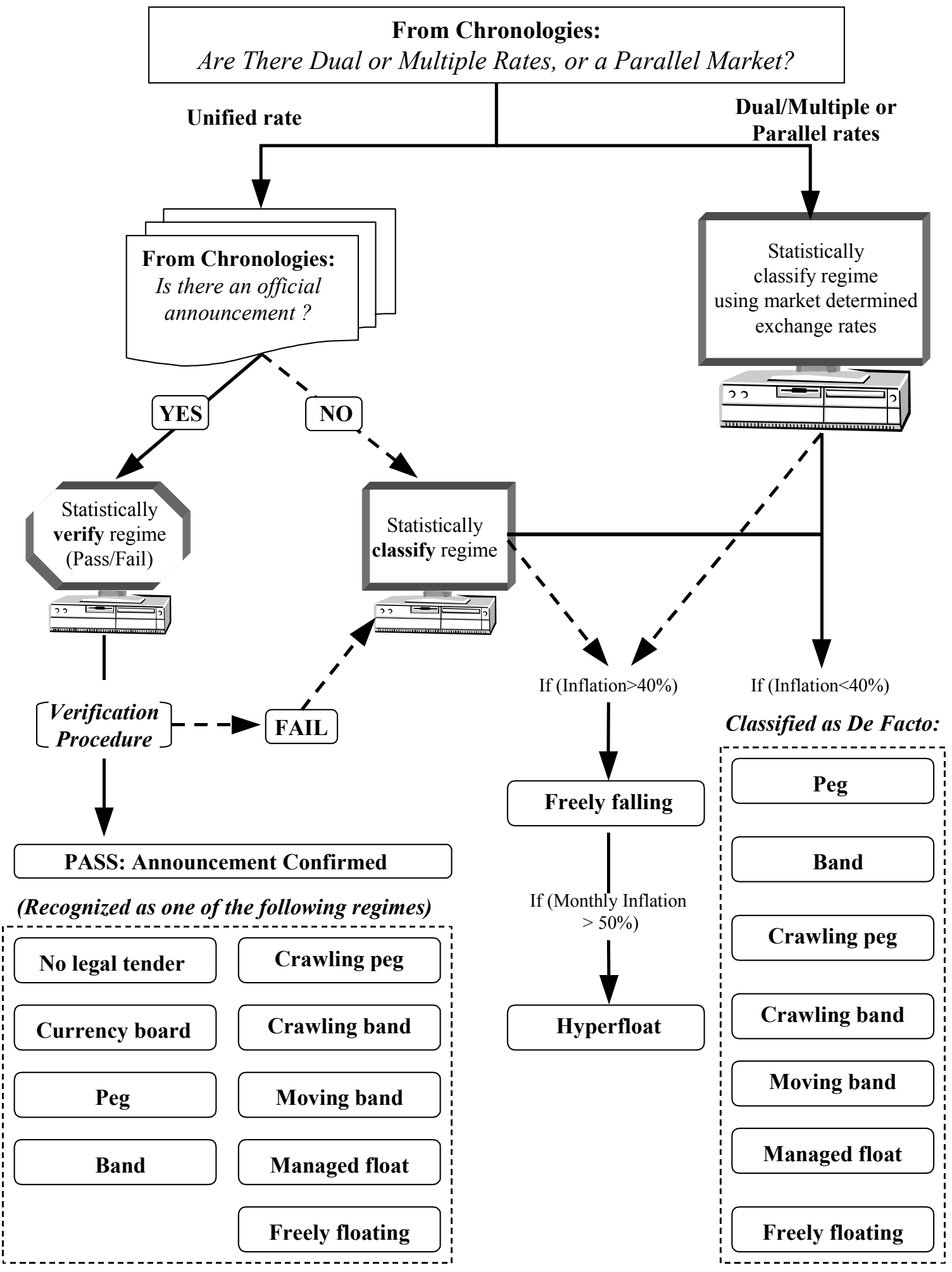


Our statistical measures include rolling two-year and five-year moving average measures of volatility (see Appendix II). The longer five-year window has priority, in order that the monthly exchange rate behavior is appropriately viewed as part of a larger regime. (We also examined the graphical evidence as a check on the classification. In practice, the main effect is to allow one to more reliably separate pegs from crawling pegs or bands, and to mark more finely the latter between moving pegs or crawling bands.)

Fourth, as discussed below, an important departure from all previous classification schemes is that we create a new separate category for countries whose twelve-month rate of inflation is above 40 percent. These episodes are classified as freely falling. ${ }^{13}$ If the country is in a hyperinflation (according to the classic Cagan definition of 50 percent or more monthly inflation), we categorize the exchange rate as a hyperfloat, a sub-species of freely falling. In Chart 2, exchange rates are plotted for two countries that were classified officially as floating over much of that period—Canada and Argentina. ${ }^{14}$ Argentina experienced a bout of hyperinflation and as Chart 2 illustrates, freely floating regimes look rather different from freely falling regimes - witness the orders of magnitude difference in the range of the $\mathrm{Y}$ scales between Canada (top of page) and Argentina (bottom). This difference is highlighted in the middle panel, which plots the Canadian dollar-US dollar rate against Argentina's Yscale; from this perspective it looks like a fixed rate! The exchange rate profile of other

\footnotetext{
${ }^{13}$ In the highly exceptional cases where, despite inflation over $40 \%$, the market rate nevertheless follows a confirmed, pre-announced band or crawl, the pre-announced regime takes precedence.

${ }^{14}$ For Argentina, this of course, refers to the period before the Convertibility Plan was introduced in April 1991.
} 
countries which experienced chronic high inflation bouts - even if these did not reach the hyperinflation stage--look more similar to Argentina in Chart 2, than to Canada. In our view, regimes associated with the myriad of problems that result from very high inflation should not be lumped under the same exchange rate arrangement as low inflation floating regimes, certainly not if one wants to contrast the macroeconomic implications of alternative exchange rate regimes.

In step five, we take up those residual regimes that have not already been classified by steps one through four. These regimes become candidates for "managed" or "freely" floating. ${ }^{15}$ To distinguish between the two, we perform some simple tests (described in detail in Appendix II) that look at the likelihood the exchange rate will move within a narrow range, as well as the mean absolute value of exchange rate changes.

When there are dual or parallel markets, we apply steps one through five to our data on parallel exchange rates and reclassify accordingly, though in our finer grid, dual rates as a whole also constitute a separate "species."

\section{Using the chronologies}

The 153 individual country chronologies in Appendix II are the central point of departure from all previous efforts. In the first instance, the data are constructed by culling information from annual issues of various secondary sources, including Pick's Currency Yearbook, Pick's World Currency Report, Pick's Black Market Yearbook, International Financial Statistics, the IMF's Annual Report on Exchange Rate Arrangements and Exchange Restrictions, and the United Nations Yearbook. Generally speaking, constructing

\footnotetext{
${ }^{15}$ Our classification of "freely floating" is the analogue of "independently floating" in the official classification.
} 
our data set required us to sort and interpret information for every year from every publication above. In addition, however, we draw on national sources to investigate apparent data errors or inconsistencies. More generally, we rely on the broader economics literature to include pertinent information not to be found in our secondary sources, such as the dates of Tablita episodes in Latin America.

The chronologies allow us to date dual or multiple exchange rate episodes, as well as to differentiate between pre-announced pegs, crawling pegs, and bands from their de facto counterparts. We think it is important to distinguish between, say, de facto pegs and announced (confirmed) pegs, because their properties are potentially different. ${ }^{16}$ At the very least, we want to provide future researchers with the data needed to ask the question. The chronologies also flag the dates for important turning points, such as when the exchange rate was allowed to float or a currency was repegged from one anchor currency to another.

Table 2 gives an example of one of our 153 chronologies shown in Appendix III, for the case of Chile. The first column gives critical dates. Note that where possible, we extend our chronologies back before 1946 (even though we can only classify from 1946 onwards); in the case of Chile we go back to 1932. The second column gives the arrangement, according to our natural classification algorithm, which may or (much more often) not correspond to the official classification. As one can see, although Chile unified rates on September 1999, it previously had some form of dual or multiple rates throughout most of its

16 Policymakers may not be indifferent between the two. In theory, at least, announcements of pegs, bands, and so on can act as a coordinating device which, by virtue of being more transparent, could invite speculative attacks. 
history. ${ }^{17}$ In these circumstances, our classification algorithm relies on the marketdetermined, rather than the official rate. In some instances, the discrepancy proved to be small. For example, from September 1998-December 1998, the official regime was a preannounced crawling band to the dollar; our statistical algorithm confirms this band even for the dual rate. Chile has also experienced several periods where the twelve-month monthly inflation exceeded 40 percent. Our algorithm automatically categorizes these as freely falling exchange rate regimes - unless there is a pre-announced peg crawling peg or narrow band that is verified, as was the case when the Tablita program was introduced on February 1978. For the freely falling cases, the second column also notes whether there was a dual market and how our algorithm would categorize the regime absent knowledge of the inflation rate. The third column in our chronology gives further sundry information on the regimeinformation we believe to be particularly important, e.g., the width of the announced and de facto bands. For Chile, which followed a crawling band policy over many sub-periods, it is particularly interesting to note the changes over time in the width of the bands. Information on the performance of the parallel market premia is also presented in the third column, as is information on currency reform. As an example of the former, we note that since 1992 the parallel premium slipped into single digits. An example of the latter is given for Chile when the peso replaced the escudo in 1975.

${ }^{17}$ Of course, since 1992 the difference between the official and parallel rate has been trivial. 
Table 2. A Sample Chronology in the Natural Classification Scheme: Chile, 1932-2001

\begin{tabular}{|c|c|c|}
\hline Date & $\begin{array}{l}\text { Classification } \\
\text { Primary/Secondary/Tertiary }\end{array}$ & Comments \\
\hline September 16, 1925- April 20, 1932 & Peg & $\begin{array}{l}\text { Gold standard. Foreign exchange controls are } \\
\text { introduced in on July } 30,1931 \text {. }\end{array}$ \\
\hline April 20, 1932-1937 & Dual Market & $\begin{array}{l}\text { Pound Sterling is reference currency. Suspension of } \\
\text { gold standard. }\end{array}$ \\
\hline 1937-February, 1946 & Managed floating/Multiple rates & US Dollar is the reference currency \\
\hline March 1946-May 1947 & $\begin{array}{l}\text { Freely falling/Managed } \\
\text { floating/Multiple rates }\end{array}$ & US Dollar is the reference currency \\
\hline June 1947-October 1952 & Managed floating/Multiple rates & \\
\hline November 1952-April 16, 1956 & $\begin{array}{l}\text { Freely falling/Managed } \\
\text { floating/Multiple rates }\end{array}$ & US Dollar is the reference currency \\
\hline April 16, 1956-August 1957 & $\begin{array}{l}\text { Freely falling/Managed floating/Dual } \\
\text { Market }\end{array}$ & \\
\hline September 1957-June 1958 & Managed floating/Dual Market & \\
\hline July 1958-January 1, 1960 & $\begin{array}{l}\text { Freely falling/Managed floating/Dual } \\
\text { Market }\end{array}$ & \\
\hline January 1, 1960-January 15,1962 & Peg to US Dollar & The Escudo replaces the peso. \\
\hline January $15,1962-$ April 1964 & $\begin{array}{l}\text { Freely falling/Managed } \\
\text { floating/Multiple rates }\end{array}$ & \\
\hline January $15,1962-$ June 1971 & Managed floating/Multiple rates & \\
\hline July 1971 -June 29,1976 & $\begin{array}{l}\text { Freely falling/Multiple exchange } \\
\text { rates }\end{array}$ & $\begin{array}{l}\text { On September 29, } 1975 \text { the Peso replaced the } \\
\text { Escudo. October } 1973 \text { classifies as a hyperfloat. }\end{array}$ \\
\hline June 29, 1976-January 1978 & $\begin{array}{l}\text { Freely falling/Crawling peg to US } \\
\text { Dollar }\end{array}$ & \\
\hline February 1978-June 1978 & $\begin{array}{l}\text { Pre announced crawling peg to US } \\
\text { Dollar/Freely falling }\end{array}$ & The Tablita Plan \\
\hline July 1978-June 30, 1979 & $\begin{array}{l}\text { Pre announced crawling peg to US } \\
\text { Dollar }\end{array}$ & The Tablita Plan \\
\hline June 30, 1979-June 15, 1982 & Peg to US Dollar & The second phase of the Tablita Plan \\
\hline June 15, 1982-December, 1982 & $\begin{array}{l}\text { Freely falling/Managed floating/Dual } \\
\text { Market }\end{array}$ & \\
\hline December 1982-December 8, 1984 & Managed floating/Dual Market & $\begin{array}{l}\text { Parallel market premium reaches } 102 \% \text { in early } \\
\text { 1983. On March } 1983 \text { the intentions to follow a PPP } \\
\text { rule was announced. }\end{array}$ \\
\hline December 8, 1984-January 1988 & Managed floating/Dual Market & $\begin{array}{l}\text { PPP rule. The official rate is kept within a }+/-2 \% \\
\text { crawling band to US Dollar the June } 1985 \text {. Yet, } \\
\text { while the official rate remains within the band, } \\
\text { parallel market premia remain in the } 20-40 \% \text { range } \\
\text { and scores as managed floating. }\end{array}$ \\
\hline January 1988-January 1, 1989 & $\begin{array}{l}\text { De facto crawling band around US } \\
\text { Dollar/Dual Market }\end{array}$ & $\begin{array}{l}\text { PPP rule. Band width is }+/-5 \% \text {. Official pre-- } \\
\text { announced crawling band to US Dollar. Band width } \\
\text { is }+/-3 \% \text {. While the official rate remains within the } \\
\text { band narrower band, parallel market premia remain } \\
\text { in double digits. }\end{array}$ \\
\hline June 1, 1989-January 22, 1992 & $\begin{array}{l}\text { Pre announced crawling band around } \\
\text { US Dollar/Dual Market }\end{array}$ & PPP rule. Band width is $+/-5 \%$. \\
\hline January 22, 1992- January 20, 1997 & $\begin{array}{l}\text { De facto crawling band around US } \\
\text { Dollar/Dual Market }\end{array}$ & $\begin{array}{l}\text { PPP rule. Band is }+/-5 \% \text {. Official pre-announced } \\
\text { crawling band to US Dollar. Band width is }+/-10 \% \text {. } \\
\text { Parallel premium declines to below } 15 \text { percent and } \\
\text { into single digits. }\end{array}$ \\
\hline January 20, 1997-June 25, 1998 & $\begin{array}{l}\text { De facto crawling band to US } \\
\text { Dollar/Dual Market }\end{array}$ & $\begin{array}{l}\text { Official pre-announced crawling band to US Dollar. } \\
\text { Band width is }+/-12.5 \% \text {, de facto band is }+/-5 \% \text { for } \\
\text { the official rate and }+/-2 \% \text { for the parallel rate. }\end{array}$ \\
\hline June 25, 1998-September 16, 1998 & $\begin{array}{l}\text { Pre-announced crawling band to US } \\
\text { Dollar/Dual Market }\end{array}$ & Band width is, $+/-2.75 \%$ \\
\hline September 16, 1998-December 22, 1998 & $\begin{array}{l}\text { Pre announced crawling band to US } \\
\text { Dollar/Dual Market }\end{array}$ & Band width is $+/-3.5 \%$. \\
\hline December 22, 1998-September 2, 1999 & $\begin{array}{l}\text { Pre announced crawling band to US } \\
\text { Dollar/Dual Market }\end{array}$ & Band width is $+/-8 \%$. \\
\hline September 2, 1999-December 2001 & Managed floating & Rates are unified. \\
\hline
\end{tabular}

Notes: Reference currency is the US Dollar. 
The top panel of Chart 3 plots the path of exchange rate for Chile. It is evident that through much of the period shown the arrangement was one of a crawling peg or a crawling band with the rate of crawl varying through time and notably slowing as inflation began to stabilize following the Tablita plan of the early 1980s. As we will discuss in the next Section crawling pegs or bands are not at all unusual and, indeed, quite commonplace. The two bottom panels of Chart 3, which show the path of the exchange rate for India and Greece provide other examples of the many crawling pegs or bands in our sample.

\section{About the data}

As noted, we use monthly data on official and market-determined exchange rates for the period 1946-1998. In some instances, the data for the market-determined rate is available for a shorter period and Appendix I provides the particulars on a country-bycountry basis. The market-determined exchange rate data comes from various issues Pick's Currency Yearbook, Pick's Black Market Yearbooks, and Pick's World Currency Report and the official rate comes from the same sources and as well as the IMF. The quotes are end of month exchange rates and are not subject to revisions. For the countries that had one ore more monetary reforms, involving changes in the units in which the exchange rate is expressed, the data has been converted as necessary to ensure continuity.

While the quality of data on market-determined rates is likely to vary across countries and time, we believe these data to be reliable and generally far better indicators of the underlying monetary policy than are official rates. For instance, if monetary policy is more lax than is consistent with maintaining the official exchange rate unchanged one would expect the market-determined rate to start depreciating ahead of the official realignment. When the official realignment occurs - it is simply a validation of what had previously 
transpired in the free market. Indeed, this is the pattern shown in the three panels of Chart 4 for the cases of Bolivia, Indonesia, and Iran. This pattern also emerges in the developed European economies and Japan in the years following World War II; it is quite typical.

To illustrate more formally that the market-based exchange rate is a better indicator of the monetary policy stance than the official rate and that changes in the former systematically predict changes in the latter, we regressed for each of the developing countries in our sample a currency crash dummy on the parallel market premia lagged one to six months. ${ }^{18}$ If the market rate consistently anticipates devaluations of the official rate, its coefficient should be positive and significant. If, in turn, the official exchange rate does not validate the market rate then, the coefficient on the lagged market exchange rate will be negative. As shown in Table 3 , in the overwhelming number of cases ( 97 percent), the coefficient on the market-determined exchange rate is positive and consistent with the view that the monetary policy stance is better reflected in market rates. In about 81 percent of the cases, the sign on the coefficient was positive and statistically significant. Indeed, for Western Hemisphere as a region the coefficient on the parallel premia was significant I all the cases.

\footnotetext{
${ }^{18}$ Two definitions of currency crashes are used. A severe currency crash refers to a $25 \%$ or higher monthly depreciation which is at least $10 \%$ higher than the previous month's depreciation. The "milder" version represents a $12.5 \%$ monthly depreciation which is at least $10 \%$ above the preceding month's depreciation; see details in Appendix II. To put in perspective the monthly depreciations annualized are 1, 355\% and 310\%, respectively.
} 
Table 3. Is the Parallel Market a Good Predictor of Crashes in the Official Rate? Summary of the Results

\begin{tabular}{|l|l|l|}
\hline & "Milder" crash & "Severe" crash \\
\hline Percent of countries for which the coefficient is positive & 97.1 & 97.1 \\
\hline Percent for which the coefficient is positive and significant & 81.4 & 80.0 \\
\hline Percent for which the coefficient is negative & 2.9 & 2.9 \\
\hline Percent for which the coefficient is negative and significant & 1.4 & 1.4 \\
\hline
\end{tabular}

Notes: Two definitions of currency crashes are used. A "severe" currency crash refers to a $25 \%$ or higher monthly depreciation which is at least $10 \%$ higher than the previous month's depreciation. The "milder" version represents a $12.5 \%$ monthly depreciation which is at least $10 \%$ above the preceding month's depreciation. To put in perspective the monthly depreciations annualized are $1,355 \%$ and $310 \%$, respectively.

At the ten percent confidence level or higher.

\section{The "Artificial" and "Natural" Taxonomies of Exchange Rate Arrangements}

We are now prepared to offer some broad descriptive statistics about our "natural" classification scheme and how it compares to the standard "artificial" one.

\section{Alternative taxonomies: comparing the basic categories}

Altogether, our taxonomy of exchange rate arrangements includes the 14 classifications sketched in Table 4 (15 if hyperfloats are treated as a separate category). Because we sometimes want to compare our classification regime with the official one, we can also collapse our 14 types of arrangements into 5 broader categories. The least flexible arrangements are assigned lower values in our scale as shown in the second column of Table 4.

In the finer grid, we distinguish between pre-announced policies and the less transparent de facto regimes. Since the former involve an explicit announcement while the latter leaves it to financial market analysts to figure out what the implicit exchange rate policy is, in the finer classification we treat pre-announcement as less flexible than de facto and accordingly assign it a lower number in our scale. For those not interested in testing whether announcements serve as a coordinating device (say to make a speculative attack 
more likely) and are exclusively interested in sorting out the degree of observed exchange rate flexibility, the bottom panel of Table 4 presents a coarser ranking according to the degree of flexibility from one to five. However, in both the coarse and fine grid, it is imperative to treat freely falling as a separate category. These sorting strategies categorize cover the period January 1946-December 2001 for those with unified rates, and January 1946-December 1998 for those countries with dual markets.

Table 4. The Fine and Coarser Grids of the Natural Classification Scheme

\begin{tabular}{|l|l|l|}
\hline Natural Classification Bucket & $\begin{array}{l}\text { Number assigned to } \\
\text { category in fine grid }\end{array}$ & $\begin{array}{l}\text { Number assigned to } \\
\text { category in coarse grid }\end{array}$ \\
\hline No separate legal tender & 1 & 1 \\
\hline $\begin{array}{l}\text { Pre announced peg or currency board } \\
\text { arrangement }\end{array}$ & 2 & 1 \\
\hline $\begin{array}{l}\text { Pre announced horizontal band that is narrower } \\
\text { than or equal to }+/-2 \%\end{array}$ & 3 & 1 \\
\hline De facto peg & 4 & 1 \\
\hline Pre announced crawling peg & 5 & 2 \\
\hline $\begin{array}{l}\text { Pre announced crawling band that is narrower } \\
\text { than or equal to }+/-2 \%\end{array}$ & 6 & 2 \\
\hline De facto crawling peg & 7 & 2 \\
\hline $\begin{array}{l}\text { De facto crawling band that is narrower than or } \\
\text { equal to }+/-2 \%\end{array}$ & 8 & 2 \\
\hline $\begin{array}{l}\text { Pre announced crawling band that is wide than } \\
\text { or equal to }+/-2 \%\end{array}$ & 9 & 2 \\
\hline $\begin{array}{l}\text { De facto crawling band that is narrower than or } \\
\text { equal to }+/-5 \%\end{array}$ & 10 & 3 \\
\hline $\begin{array}{l}\text { Moving band that is narrower than or equal to } \\
+/-2 \% \\
\text { (i.e., allows for both appreciation and } \\
\text { depreciation over time) }\end{array}$ & 11 & 3 \\
\hline Managed floating & & 4 \\
\hline Freely floating & 12 & 5 \\
\hline Freely falling & 13 & 3 \\
\hline Source Th & 14 & \\
\hline
\end{tabular}

Source: The authors. 


\section{Fact and fiction: Natural and Artificial?}

We are now prepared to contrast the official view of the history of exchange rate regimes with the view that emerges from employing our alternative methodology. To facilitate comparisons, we will focus mainly on the coarse grid version of the natural system.

For example, in 1950, the IMF's then two tier classification (peg and "other") had 65 percent of countries listed as pegs, as Chart 5 illustrates. As one can also see from Chart 5, according to our natural classification system, less than forty percent of all regimes at this time were pegs (since countries had dual/parallel rates which did not qualify as pegs.) In fact, this coarse comparison understates the differences between the two classification systems since some of our "pegs" were not considered pegs under the official classification; in turn, our algorithm rejects almost half of the official pegs as true pegs. It is worth noting that our reclassification of the early post-war years impacts not only on developing countries, but on industrialized countries as well; nearly all the European countries had active parallel markets after World War II.

A second (less important) reason why our scheme shows less pegs is that the IMF's pre-1997 allowed countries to declare their regimes as pegged to an undisclosed basket of currencies. This practice was especially popular during the 1980 s, and it was under the umbrella of pegging to an undisclosed basket of currencies that a great deal of managed floating, freely floating and freely falling actually took place.

For the period 1974-1990, the official classification has roughly 60 percent of all regimes as pegs; our classification has only half as many. Again, as we shall see shortly, this comparison understates the differences since some of our pegs are not official pegs. For the years 1974-1990, and 1991-2001, one can see two major trends. First, "freely falling" 
continues to be a significant category, accounting for 12 percent of all regimes from 19741990, and 13 percent of all regimes from 1991-2001. For the transition economies in the 1990s, over 40 percent of the observations are in the freely falling category. Table 5 looks at what kinds of official exchange rate regimes are most closely associated with our freely falling category. We find that peg, managed floating and independently floating contribute in almost equal measure to our freely falling category. Only limited flexibility-a relatively small group of mostly European countries in the official classification-is not associated with freely falling. The last item in the table shows that 62 percent of all freely falling exchange rate systems took place under the guise of dual rates.

Table 5. Behind Freely Falling: Exchange Rate Official Arrangements in Place during Freely Falling Episodes

1970-2001

(Percent of Total Cases)

\begin{tabular}{ccccc}
\hline \hline Peg & $\begin{array}{c}\text { Limited } \\
\text { Flexibility }\end{array}$ & $\begin{array}{c}\text { Managed } \\
\text { Floating }\end{array}$ & $\begin{array}{c}\text { Independently } \\
\text { Floating }\end{array}$ & $\begin{array}{c}\text { (Dual or parallel } \\
\text { rates) }\end{array}$ \\
\hline \hline & & & & \\
28.2 & 0.0 & 35.7 & 36.1 & $(61.8)$ \\
\hline \hline
\end{tabular}

Sources: International Monetary Fund, Annual Report on Exchange Arrangements and Exchange Restrictions and International Financial Statistics, Pick and Sédillot (1971), International Currency Analysis, World Currency Report, various issues.

Second, the natural classification scheme reveals a bunching to the middle in terms of exchange rate flexibility, when compared to the official monetary history of the world. Limited flexibility - which under the natural classification is dominated by de facto crawling pegs - becomes notably more important. From being a very small class under the official scheme, the natural classification algorithm elevates limited flexibility to the second most important grouping over the past decade, just behind pegs. Another startling difference is the 
reduced importance of freely floating. According to the official classification, more than 30 percent of countries were independently floating during 1991-2001. According to the natural classification, less than 10 percent were freely floating. This is partly a manifestation of what Calvo and Reinhart (2002) term "fear of floating", but equally because we assign high inflation floats to our new freely falling category. Indeed, more countries had freely falling exchange rates than had freely floating exchange rates!

The contrast between the old and new classification systems becomes even more striking when one sees just now small the overlap is between the two classifications country by country, month by month. As we can see from Table 6 , if the official designation of the regime is a peg (1970-2001), there is a 44 percent chance our algorithm will categorize it into a more flexible arrangement. If the official regime is a float, there is a 31 percent chance we will categorize it as a peg or limited flexibility. If the official regime is a managed float, there is 53 percent chance our algorithm will categorize it as a peg or limited flexibility. Whether the official regime is a float or peg, it is virtually a coin toss whether the natural algorithm will yield the same result. The bottom of the table gives the pairwise correlation between the two classifications, with the official classification running from 1 (peg) to 4 (independently floating), and the natural classification running from 1 (peg) to 5 (freely falling). The simple correlation coefficient is only .42. As one can confirm from the chronologies, the greatest overlap occurs in the classification of the G3 currencies and of the limited flexibility European arrangements. Elsewhere, and especially in developing countries, the two classifications differ significantly, as we shall see. 
Table 6. Floating Pegs and Pegged Floats: Revisiting the Past, 1970-2001

\begin{tabular}{l}
\hline \hline $\begin{array}{l}\text { Probability that the regime is dual, managed or independently floating according to } \\
\text { natural classification conditional on being classified as a peg in the official standard } \\
\text { classification }\end{array}$ \\
$\begin{array}{l}\text { Probability that the regime is limited flexibility, managed or independently floating } \\
\text { or freely falling cording to natural classification conditional on being classified as a } \\
\text { peg in the official standard classification }\end{array}$
\end{tabular}

Pairwise correlation between the Standard and Natural classification

Source: The authors' calculations.

\section{The pegs that float}

Chart 6 plots the parallel market premium since January 1946, in percent, for Africa, Asia, Europe and Western Hemisphere. As is evident from the Chart, for all the regions except Europe, it would be difficult to make the case that the breakdown of Bretton Woods was a singular event, let alone a sea change. The levels of pre- and post-1973 volatilities in the market determined exchange rate - as revealed by the parallel market premia are remarkably similar for the developing world. Note that for all regions, we exclude the freely falling episodes which would significantly increase the volatility but also distort the scale.

As regards Europe, the story told by Chart 6 is even more surprising. From 1946 until the arrival of the 1960s, Europe was de facto floating under the guise of pegged official exchange rates. Each time official rates were realigned, the story had already unfolded in the parallel market. While the volatility of the gap between the official rate and the market exchange rate is not quite in the order of magnitude observed in the developing world, the 
volatility of the parallel rate is quite similar to the volatility of today's managed or freely floating exchange rates. The disappearance of the premia at such a late stage - the 1960s-suggests that the duration of the "true" Bretton Woods system of pegged exchange rates was much shorter lived than most textbooks suggest. As show earlier for Chile and India in the top two panels of Chart 2, there are many interesting country examples that illustrate visually just how little changed before and after the breakup of Bretton Woods. Clearly, more careful statistical testing is required to make categorical statements about when a structural break took place; but it is obvious from the charts that whatever break might have taken place must be relatively minor quantitatively compared to usual image of the move from fixed to flexible rates.

\section{The floats that peg}

Chart 7 provides a more general flavor of how exchange rate flexibility has evolved over time and across regions. The chart plots five-year moving averages of the probability that the monthly percent change in the exchange rate remains within a two percent band for Africa, Asia, Europe and Western Hemisphere (excluding only the United States). Hence, under a pegged arrangement, assuming no adjustments to the parity are made, these probabilities should equal 100 percent. As before, we exclude the freely falling episodes. For comparison purposes, the figures plot the unweighted regional averages against the unweighted averages for the "committed floaters". (The committed floaters group include the following exchange rates against the dollar: Yen, DM (Euro), Australian dollar, and the Pound Sterling.) 
It is evident for all regions (this applies the least to Africa) that the monthly percent variation in the exchange rate has typically been kept to a minimum - there is a great deal of smoothing of exchange rate fluctuations in all regions when compared to the usual monthly variations of the committed floaters. The smoothing is most evident in Asia where the index hovers around 90 percent for most of the period, versus 60-70 percent for the floaters.

Hence, over time, the nature of the classification problem has evolved from labeling something as a peg when it is not, to labeling something as floating when the degree of exchange rate flexibility has in fact been very limited.

\section{Reflections on the choice of nominal anchor}

The data set underlying our analysis offers a number of potential insights about how the choice of exchange rate regime impacts on macroeconomic performance. A very basic one is inflation. Many developing countries today are faced with the question of whether to use the exchange rate as an explicit or implicit nominal anchor. It is widely recognized that fixing to a strong major currency can pose problems if the developing country lags in productivity growth, or if it experiences recessions at different times from the anchor. How big is this problem quantitatively? It is very instructive to look at the CFA franc zone countries in Africa, a group of more than a dozen nations that have pegged more or less continuously to the French franc since 1946 (with the notable exception of a one time 50 percent devaluation in 1994). Although these countries have (by and large) enjoyed a relatively high degree of exchange rate stability, they also constitute the region of the world that has had experienced by far the most frequent bouts of deflation. During 1970 to 2001, as shown in the top panel of Chart 8 , these countries, on average had deflations (as measured by a decline in the twelve-month percent change in the consumer price index) about 28 percent 
of the time! This can be interpreted as "a cost" of having the exchange rate as the nominal anchor and requiring that all adjustment in the real exchange rate to be borne by the price level. It merits analysis to explore to what extent these prolonged bouts of deflation have contractionary consequences for output.

Of course, the flip side having such a "tight" nominal anchor is not having a nominal anchor at all. As shown in the bottom panel of Chart 8, freely falling is endemicparticularly in Western Hemisphere (i.e., Latin America) and in the transition economies, which include the republics that made up the former Soviet Union. Freely falling, as we discuss in the next subsection, is not only problematic from the point of view of having no price stability and the resultant high degree of uncertainty about nominal magnitudes. It is also a main stumbling block to economic growth.

\section{Does the exchange rate regime matter?}

The question of whether the exchange rate arrangement matters for various facets of economic activity is, indeed, a far-reaching and significant question that has been tackled over the years in the literature on international trade and finance, and is beyond the scope and aims of this paper. However, a few simple exercises are illustrative of the potential usefulness of our Natural classification. First consider Table 7 below, the top row of which is the same as the first four entries in Table 8 which follows. Recall that if the official regime classification is a peg, the probability that the regime is actually "freely falling" is $\mathbf{2 8}$

percent. The probability that an exchange rate regime with an official classification of independently floating is one the natural algorithm would label as freely falling is 36 percent. Simply taking out treating dual arrangements separately drastically alters the picture. Pegs 
with unified rates accounted for only 3 percent of freely falling, though independently floating still accounts for 25 percent.

Table 7. Probability of Freely Falling Across Regimes: 1970-2001

\begin{tabular}{cccccc}
\hline \hline Period & Peg & $\begin{array}{c}\text { Percent of Total Cases } \\
\text { Limited } \\
\text { Flexibility }\end{array}$ & $\begin{array}{c}\text { Managed } \\
\text { Floating }\end{array}$ & $\begin{array}{c}\text { Independently } \\
\text { Floating }\end{array}$ & $\begin{array}{c}\text { Dual or Multiple } \\
\text { Exchange Rates }\end{array}$ \\
\hline \hline $\begin{array}{c}\text { Standard } \\
\text { Dual rates } \\
\text { treated } \\
\text { separately }\end{array}$ & 28.3 & 0.0 & 35.6 & 36.1 & 0.0 \\
\hline \hline
\end{tabular}

Sources: International Monetary Fund, Annual Report on Exchange Arrangements and Exchange Restrictions and International Financial Statistics, Pick and Sédillot (1971), International Currency Analysis, World Currency Report, various issues.

In a similar vein, we compare the average annual inflation rate and the average annual per capita GDP growth rate across exchange rate regimes under (a) the standard classification and (b) a modified standard classification that simply separates dual markets into a different bucket. The results are shown in Table 8 for the entire sample. As Table 8 highlights, there are significant differences in the inflation averages across the two classification schemes. The standard classification shows very high average inflation rates in three of the four "standard" categories; only limited flexibility exhibits moderate inflation. The difference is particularly stark when the independently floating cases are assessed, with the standard official classification showing average annual inflation rate of 174 percent versus 46 percent for the classification that separates out dual rates. Similarly, annual real per capita GDP growth is twice as large for the freely floating cases under our classification. These discrepancies are in a large part owing to our extra category of dual rates, which houses a 
disproportionately large number of the high inflation cases - notice the average inflation rate for dual rates is 167 percent.

Table 8. Do Classifications Matter?

Growth and Inflation across Regimes: 1970 to 2001

\begin{tabular}{|c|c|c|c|c|c|}
\hline \multicolumn{6}{|c|}{ Average Annual Inflation } \\
\hline $\begin{array}{c}\text { Classification } \\
\text { scheme }\end{array}$ & Peg & $\begin{array}{c}\text { Limited } \\
\text { Flexibility } \\
\end{array}$ & $\begin{array}{c}\text { Managed } \\
\text { Floating } \\
\end{array}$ & Freely Floating & $\begin{array}{l}\text { Dual or Multiple } \\
\text { Exchange Rates } \\
\end{array}$ \\
\hline $\begin{array}{c}\text { Standard } \\
\text { Dul rates as }\end{array}$ & 38.8 & 5.3 & 74.8 & 173.9 & n.a. \\
\hline $\begin{array}{l}\text { separate } \\
\text { category }\end{array}$ & 20.7 & 10.1 & 29.7 & 45.5 & 167.4 \\
\hline \multicolumn{6}{|c|}{ Average Annual Per Capita GDP Growth } \\
\hline Standard & 1.4 & 2.2 & 1.9 & 0.5 & n.a. \\
\hline $\begin{array}{c}\text { Dual rates as a } \\
\text { separate } \\
\text { category }\end{array}$ & 1.7 & 2.6 & 1.5 & 1.1 & 0.8 \\
\hline
\end{tabular}

Source: International Monetary Fund, World Economic Outlook.

However, simply modifying the standard classification is far less revealing than the Natural classification. The contrast is stark both in terms of the level of per capital GDP, growth, and inflation averages; see Charts 9-12. The implications for trade volume are also interesting. Not surprisingly, freely falling regimes (including the subcategory "hyperfloat") exhibit an average annual inflation rate 443 percent versus an inflation average in the 6 to 15 percent range for the other categories (Chart 7). As shown in Chart 10, freely falling has the lowest per capita income (US $\$ 3,476$ ) of any category, while freely floating has the highest (US $\$ 13,602$ ) - a difference that is clouded in the original standard classification when freely falling cases are included in the freely (independently) floating category for lack of a better alternative. In the official IMF historical classification, limited flexibility, which was almost entirely comprised of European countries, showed the largest per capita income. 
Stark differences in average per capita real GDP growth also emerge. In particular, growth is negative for freely falling, $-2.5 \%$, versus positive growth rates in the 1.6-2.4 range for the other categories (Chart 11). Once freely falling is treated as a separate category, the differences between our other classifications pale relative to the differences between freely falling and not freely falling. In the standard classification, freely floating shows a meager average growth rate of 0.5 percent for the independently floating cases. In the natural classification, which purges the freely floating category from its freely floating counterparts, the average growth rate quadruples for the floaters to 2.3 percent. Clearly, this exercise highlights the importance of treating as a separate classification the freely falling episodes.

On trade volume (i.e., exports plus imports as a share of GDP), Chart 12 reveals that for the Natural classification, the differences between fix and flex are noticeably greater than for the official classification. Trade volume is the highest for pegs and for limited flexibility, and it is lowest for freely floating; the gap between these is about 36 percent. Obviously, we cannot assess causation here, but the striking differences merit further exploration.

\section{Concluding Remarks}

We have argued that the official classification has serious flaws. Systems with extensive dual or parallel markets, which accounted for about half of all exchange rate arrangements in our sample in the 1950s and 1960s and early 1970s, are not treated as a separate category. Most often, these regimes have been labeled pegs by all other classifications, notably including the official classification. Given that a very significant share of these "pegs" masked high inflation and large parallel/dual market premiums, it is clear the standard categorization can be highly misleading. According to our new "natural" 
classification scheme, across all countries and all months, 45 percent of all post-1970 observations officially labeled as a "peg" should, in fact, have been classified as limited flexibility, managed or freely floating — or worse, "freely falling". In the 1980s and 1990s, a new type of misclassification problem emerged and the odds of being officially labeled a "managed float" when there was a de facto peg or crawling peg was about 53 percent. We thus find that the official history of exchange rates can be profoundly misleading, as a striking number of pegs are much better described as floats, and vice-versa.

These misclassification problems deeply cloud our view of history along some very basic dimensions. Using the official classification for the period 1970-2001, one would conclude that a freely floating exchange rate is not a very attractive option-it produces an average annual inflation rate of 174 and a paltry average per capita growth rate of 0.5 percent. This is the worst performance of any arrangement. Our classification presents a very different picture: free floats deliver an average inflation which is less than 10 percent (the lowest of any exchange rate arrangement), and an average per capita growth rate of 2.3 percent. We believe that the new view of exchange rate history offered here may well lead to a significant reassessment of how different regimes perform.

In light of the dramatic revision of exchange rate classifications presented here, Milton Friedman's (1953) oft-ridiculed depiction of floating exchange rates no longer looks so foolish. Friedman, of course, argued that flexible exchange rates were preferable to fixed rates because they prevented small inflation differentials from cumulating and eventually forcing a big devaluation. Most commentators have suggested that Friedman was completely wrong in his prediction of how flexible rates would work, and that post-1973 flexible rates would prove far more volatile than he had ever imagined. It is true that exchange rates across 
the dollar, yen and DM (now euro) did become notably more volatile after the breakup of Bretton Woods in 1971, at least in comparison with the 1960s. But for most other countries, the main trend is that after 1973, more countries effectively adopted crawling pegs vis-à-vis their anchor, with very little volatility - much as Friedman had envisioned. If one wants to criticize Friedman (1953), it is perhaps better to focus on his depiction of fixed exchange rates, which he portrayed as making occasional big moves instead of frequent small adjustments. In practice, much de facto floating was done through the back door of parallel markets. As a result, the effective adjustment of exchange rates under "pegging" was in many respects far smoother than Friedman described. Indeed, for many developing countries, the market-determined exchange rate looks remarkably similar during and after the Bretton Woods system--they were de facto crawling pegs both before and after the break up. The remarkable and durable popularity of crawling pegs is indeed a new fact that needs to be better understood and rationalized. So, not only is it important to rethink the empirical literature on exchange rate regimes, our new stylized facts make it important to rethink theoretical comparisons of exchange rates as well. 


\section{References}

Baxter, Marianne, and Alan Stockman, (1989). "Business Cycle and Exchange Rate Regime: Some International Evidence,” Journal of Monetary Economics Vol. 23, 377-400.

Calvo, Guillermo, and Carmen M. Reinhart, (2002). "Fear of Floating," Quarterly Journal of Economics, forthcoming.

Côté, Agathe, (1994). “Exchange Rate Volatility and Trade: A Survey,” Bank of Canada Working Paper 94-5.

Dedola, Luca, and Sylvain Leduc, (2001). "Why is the Business Cycle Behavior of Fundamentals Alike Across Exchange Rate Regimes? Oesterreichische Nationalbank Working Paper 53.

Easterly, William, (2001). The Elusive Quest for Growth (MIT Press: Cambridge, MA).

Flood, Robert P., and Andrew K. Rose, (1995). "Fixing Exchange Rates: A Virtual Quest for Fundamentals," Journal of Monetary Economics.

Frankel, Jeffrey A., and Andrew K. Rose, (1996). Currency Crashes in Emerging Markets: An Empirical Treatment, Journal of International Economics, Vol. 41, No.3/4, November, 351-368.

Glick, Reuven, (2000). "Fixed or Floating: Is It Still Possible to Manage in the Middle?" Pacific Basin Working Paper No. PB00-02, Federal Reserve Bank of San Francisco.

Gosh, Atish, Anne-Marie Gulde, Jonathan Ostry, and Holger Wolfe, (1997). "Does the Nominal Exchange Rate Regime Matter?, NBER Working Paper No. 5874, January.

International Monetary Fund, various issues, (1949-1978). Annual Report on Exchange Restrictions (International Monetary Fund: Washington DC)

International Monetary Fund, various issues, (1979-2001). Annual Report on Exchange Arrangements and Exchange Restrictions

International Currency Analysis, World Currency Yearbook (International Currency Analysis: New York).

Levy-Yeyati, Eduardo, and Federico Sturzeneger, (2002). "Classifying Exchange Rate Regimes: Deeds vs. Words," mimeograph, Universidad Torcuato Di Tella.

Mason, Stephen F., (1962). A History of the Sciences, (Collier Books: New York). 
Masson, Paul R., (2000). "Exchange Rate Regime Transitions," Journal of Development Economics Vol. 64, 571-586.

Pick, Franz, various issues, (1955-1982). Pick's Currency Yearbook (Pick Publishing Corporation, New York).

Pick, Franz, various issues, (1945-1955). World Currency Reports (Pick Publishing Corporation, New York).

Pick, Franz, and René Sédillot (1971). All the Monies of the World: A Chronicle of Currency Values, (Pick Publishing Corporation, New York).

Wickham, Peter, (2002). "Do Flexible Exchange Rates of Developing Countries Behave Like the Floating Exchange Rates of Industrialized Countries?” IMF Working Paper. 


\section{Appendix I. The Data}

Table AI.1. Country Coverage

\begin{tabular}{|c|c|c|}
\hline Country & Official exchange rate & Parallel market exchange rate \\
\hline Albania & 1954:12-2001:12 & 1954:12-1998:12 \\
\hline Algeria & $1946: 1-2001: 12$ & $1955: 1-1998: 12$ \\
\hline Argentina & 1946:1-2001:12 & 1946:1-1998:12 \\
\hline Armenia & 1992:4-2001:12 & n.a. \\
\hline Australia & 1946:1-2001:12 & 1946:1-1998:12 \\
\hline Austria & $1946: 1-2001: 12$ & 1946:1-1998:12 \\
\hline Azerbaijan & 1992:12-2001:12 & n.a. \\
\hline Belarus & $1992: 1-2001: 12$ & 1991:8-1998:12 \\
\hline Belgium & $1946: 1-2001: 12$ & $1946: 1-1998: 12$ \\
\hline Benin & 1946:1-2001:12 & 1970:7-1998:12 \\
\hline Bolivia & 1946:1-2001:12 & 1948:1-1998:12 \\
\hline Bosnia-Herzegovina & 1997:1-2001:12 & n.a. \\
\hline Botswana & 1946:1-2001:12 & 1989:1-1998:12 \\
\hline Brazil & 1946:1-2001:12 & 1946:1-1998:12 \\
\hline Bulgaria & 1946:7-2001:12 & 1946:7-1998:12 \\
\hline Burkina Faso & 1946:1-2001:12 & 1970:7-1998:12 \\
\hline Burundi & 1946:1-2001:12 & 1983:1-1998:12 \\
\hline Cameroon & 1946:1-2001:12 & 1970:7-1998:12 \\
\hline Canada & 1946:1-2001:12 & 1947:1-1998:12 \\
\hline Central African & 1946:1-2001:12 & 1970:7-1998:12 \\
\hline \multicolumn{3}{|l|}{ Republic } \\
\hline Chad & 1946:1-2001:12 & 1970:7-1998:12 \\
\hline Chile & 1946:1-2001:12 & 1948:1-1998:12 \\
\hline China & 1951:1-2001:12 & 1949:9-1998:12 \\
\hline Colombia & 1946:1-2001:12 & 1952:1-1998:12 \\
\hline $\begin{array}{l}\text { Congo, Democratic } \\
\text { Republic of }\end{array}$ & 1946:1-2001:12 & 1962:1-1996:12 \\
\hline Congo, Republic of & 1946:1-2001:12 & 1970:7-1998:12 \\
\hline Costa Rica & $1946: 1-2001: 12$ & 1948:1-1998:12 \\
\hline Cote D'Ivoire & 1946:1-2001:12 & 1970:7-1998:12 \\
\hline Croatia & 1992:12-2001:12 & 1991:12-1998:12 \\
\hline Cyprus & 1955:1-2001:12 & 1970:7-1998:12 \\
\hline Czech Republic & 1946:1-2001:12 & 1946:1-1998:12 \\
\hline Denmark & 1946:1-2001:12 & 1946:1-1998:12 \\
\hline Dominican Republic & 1946:1-2001:12 & 1960:3-1998:12 \\
\hline Ecuador & 1946:1-2001:12 & 1947:1-1998:12 \\
\hline Egypt & $1946: 1-2001: 12$ & 1946:1-1998:12 \\
\hline El Salvador & 1946:1-2001:12 & 1961:1-1998:12 \\
\hline Equatorial Guinea & 1946:1-2001:12 & 1970:7-1998:12 \\
\hline Estonia & $1992: 62001: 12$ & 1991:8-1998:12 \\
\hline Finland & 1946:1-2001:12 & 1946:1-1998:12 \\
\hline France & 1946:1-2001:12 & 1946:1-1998:12 \\
\hline Gabon & 1946:1-2001:12 & 1970:7-1998:12 \\
\hline Gambia & 1946:1- 2001:12 & 1985:1-1998:12 \\
\hline Georgia & 1995:10-2001:12 & n.a. \\
\hline Germany & $1946: 1-2001: 12$ & 1946:1-1998:12 \\
\hline Ghana & 1946:1- 2001:12 & 1962:3-1998:12 \\
\hline Greece & 1946:1-2001:12 & 1946:1-1998:12 \\
\hline
\end{tabular}


Table AI.1. Country Coverage (continued)

\begin{tabular}{|c|c|c|}
\hline Country & Official exchange rate & Parallel market exchange rate \\
\hline Guatemala & 1946:1-2001:12 & 1985:1-1998:12 \\
\hline Guinea & 1949:1-2001:12 & 1970:7-1998:12 \\
\hline Guinea-Bissau & $1946: 1-2001: 12$ & 1970:7-1998:12 \\
\hline Guyana & $1946: 1-2001: 12$ & $1985: 1-1998: 12$ \\
\hline Haiti & $1946: 1-2001: 12$ & $1985: 1-1998: 12$ \\
\hline Honduras & 1946:1-2001:12 & $1985: 1-1998: 12$ \\
\hline Hong Kong & $1946: 1-2001: 12$ & $1946: 1-1998: 12$ \\
\hline Hungary & $1946: 8-2001: 12$ & $1946: 8-1998: 12$ \\
\hline Iceland & $1946: 1-2001: 12$ & 1949:1-1998:12 \\
\hline India & $1946: 1-2001: 12$ & $1946: 1-1998: 12$ \\
\hline Indonesia & $1946: 1-2001: 12$ & 1947:1-1998:12 \\
\hline Iran & $1946: 1-2001: 12$ & $1947: 1-1998: 12$ \\
\hline Iraq & $1946: 1-2001: 12$ & $1947: 2-1998: 12$ \\
\hline Ireland & $1946: 1-2001: 12$ & $1946: 1-1998: 12$ \\
\hline Israel & $1948: 5-2001: 12$ & $1946: 1-1998: 12$ \\
\hline Italy & $1946: 3-2001: 12$ & $1946: 1-1998: 12$ \\
\hline Jamaica & $1946: 1-2001: 12$ & $1974: 1-1998: 12$ \\
\hline Japan & $1946: 3-2001: 12$ & 1946:3-1998:12 \\
\hline Jordan & $1950: 7-2001: 12$ & 1955:1-1998:12 \\
\hline Kazakhstan & 1993:11-2001:12 & n.a. \\
\hline Kenya & $1946: 12-2001: 12$ & 1966:12-1998:12 \\
\hline Kuwait & 1949:9-2001:12 & 1970:7-1998:12 \\
\hline Kyrgyz Republic & $1993: 5-2001: 12$ & n.a. \\
\hline Laos & $1946: 1-2001: 12$ & 1959:1-1998:12 \\
\hline Latvia & $1992: 2-2001: 12$ & 1991:8-1998:12 \\
\hline Lebanon & $1946: 1-2001: 12$ & 1946:1-1998:12 \\
\hline Lesotho & 1946:1-2001:12 & 1985:1-1998:12 \\
\hline Liberia & $1946: 1-2001: 12$ & 1989:1-1998:12 \\
\hline Libyan Arab Republic & $1952: 1-2001: 12$ & 1955:1-1998:12 \\
\hline Lithuania & $1992: 1-2001: 12$ & 1991:9-1998:12 \\
\hline Luxembourg & $1946: 1-2001: 12$ & 1946:1-1998:12 \\
\hline Macedonia & 1993:12-2001:12 & 1997:6-1998:12 \\
\hline Madagascar & $1946: 1-2001: 12$ & 1985:1-1998:12 \\
\hline Malawi & $1946: 12001: 12$ & 1970:7-1998:12 \\
\hline Malaysia & 1946:1-2001:12 & 1946:1-1998:12 \\
\hline Mali & $1946: 1-2001: 12$ & 1970:7-1998:12 \\
\hline Malta & $1946: 1-2001: 12$ & 1985:1-1998:12 \\
\hline Mauritania & $1946: 1-2001: 12$ & 1974:1-1998:12 \\
\hline Mauritius & $1946: 1-2001: 12$ & $1985: 1-1998: 12$ \\
\hline Mexico & $1946: 1-2001: 12$ & $1947: 1-1998: 12$ \\
\hline Moldova & 1991:12-2001:12 & n.a. \\
\hline Mongolia & $1970: 3-2001: 12$ & 1970:3-1998:12 \\
\hline Morocco & 1956:10-2001:12 & 1959:1-1998:12 \\
\hline Myanmar & $1946: 1-2001: 12$ & 1955:1-1998:12 \\
\hline Nepal & $1955: 12-2001: 12$ & $1970: 7-1998: 12$ \\
\hline Netherlands & $1946: 1-2001: 12$ & $1946: 1-1998: 12$ \\
\hline New Zealand & $1946: 1-2001: 12$ & 1948:1-1998:12 \\
\hline Nicaragua & $1946: 1-2001: 12$ & $1947: 1-1998: 12$ \\
\hline Niger & $1946: 1-2001: 12$ & $1970: 7-1998: 12$ \\
\hline Nigeria & $1946: 1-2001: 12$ & 1970:7-1998:12 \\
\hline
\end{tabular}


Table AI.1. Country Coverage (concluded)

\begin{tabular}{|c|c|c|}
\hline Country & Official exchange rate & Parallel market exchange rate \\
\hline Norway & 1946:1-2001:12 & 1946:1-1998:12 \\
\hline Pakistan & 1946:1-2001:12 & 1948:4-1998:12 \\
\hline Panama & 1946:1-2001:12 & n.a. \\
\hline Paraguay & 1946:1-2001:12 & 1951:3-1998:12 \\
\hline Peru & 1946:1-2001:12 & 1946:1-1998:12 \\
\hline Philippines & $1946: 1-2001: 12$ & 1949:8-1998:12 \\
\hline Poland & 1946:1-2001:12 & 1946:1-1998:12 \\
\hline Portugal & 1946:1-2001:12 & 1946:1-1998:12 \\
\hline Romania & $1957: 1-2001: 12$ & 1946:7-1998:12 \\
\hline Russian Federation & 1992:6-2001:12 & 1946:1-1998:12 \\
\hline Saudi Arabia & 1952:10-2001:12 & 1959:12-1998:12 \\
\hline Senegal & 1946:1-2001:12 & 1970:7-1998:12 \\
\hline Singapore & 1946:4-2001:12 & 1973:5-1998:12 \\
\hline Slovak Republic & 1993:1-2001:12 & 1993:1-1998:12 \\
\hline Slovenia & 1991:12-2001:12 & n.a. \\
\hline South Africa & 1946:1-2001:12 & 1946:1-1998:12 \\
\hline South Korea & 1946:1-2001:12 & 1946:1-1998:12 \\
\hline Spain & $1946: 1-2001: 12$ & 1946:1-1998:12 \\
\hline Sri Lanka & 1946:1-2001:12 & 1956:1-1998:12 \\
\hline Suriname & 1949:9-2001:12 & 1970:7-1998:12 \\
\hline Swaziland & 1946:1-2001:12 & 1985:1-1998:12 \\
\hline Sweden & 1946:1-2001:12 & 1946:6-1998:12 \\
\hline Switzerland & 1946:1-2001:12 & 1946:1-1998:12 \\
\hline Syrian Arab Republic & $1947: 7-2001: 12$ & 1970:7-1998:12 \\
\hline Tajikistan & 1992:1-2001:12 & n.a. \\
\hline Tanzania & 1946:12- 2001:12 & 1970:7-1998:12 \\
\hline Thailand & 1946:5-2001:12 & 1948:1-1998:12 \\
\hline Togo & $1946: 1-2001: 12$ & 1970:7-1998:12 \\
\hline Tunisia & $1956: 3-2001: 12$ & 1960:1-1998:12 \\
\hline Turkey & $1946: 1-2001: 12$ & 1946:1-1998:12 \\
\hline Turkmenistan & 1993:11-2001:12 & n.a. \\
\hline Uganda & 1946:12- 2001:12 & 1970:7-1998:12 \\
\hline Ukraine & 1992:12-2001:12 & 1991:8-1998:12 \\
\hline United Kingdom & 1946:1-2001:12 & 1946:1-1998:12 \\
\hline United States & 1946:1-2001:12 & n.a. \\
\hline Uruguay & 1946:12- 2001:12 & 1946:1-1998:12 \\
\hline Venezuela & 1946:1-2001:12 & 1960:11-1998:12 \\
\hline Zambia & $1946: 12-2001: 12$ & 1970:7-1998:12 \\
\hline Zimbabwe & 1946:12- 2001:12 & 1970:7-1998:12 \\
\hline
\end{tabular}

Table AI.2. Data Sources

\begin{tabular}{ll}
\hline \hline Variable & Source \\
\hline \hline Official exchange rate, 1946-1956 & $\begin{array}{l}\text { Pick's Currency Yearbook and Pick's World Currency } \\
\text { Report, various issues. }\end{array}$ \\
Official exchange rate, 1957-2001 & IMF, International Financial Statistics \\
Parallel Market exchange rate 1946-1980 & $\begin{array}{l}\text { Pick's Currency Yearbook, Pick's Black Market Yearbooks, } \\
\text { and Pick's World Currency Report, various issues. }\end{array}$ \\
Parallel Market exchange rate 1980-1998 & World Currency Yearbook, various issues. \\
Consumer price index, 1957-2001 & IMF, International Financial Statistics \\
\hline \hline
\end{tabular}




\section{Appendix II. The Details of the "Natural" Classification}

This appendix describes in greater detail our classification algorithm, which is outlined in Section III if the text and summarized in Figure 1 of the text. Table 4 of the text gives the different categories in our "fine" and "coarse" grids; this appendix concentrates on the fine grid.

\section{Exchange rate flexibility indices and probability analysis}

Our judgment about the appropriate exchange rate classification is shaped importantly by the time-series of several measures of exchange rate variability, based on monthly observations and averages over twenty-four month and five-year rolling windows. The first of these is the absolute percent change in the monthly nominal exchange rate. We prefer mean absolute deviations to variance to minimize the impact of outliers. These arise when, for example, there are long periods in which the exchange rate is fixed but subject to periodic large devaluations. The presence of a few outliers would imply that the variance or standard deviation would overstate the extent of exchange rate flexibility in the period around the devaluation. ${ }^{19}$

To assess whether exchange rates are kept within a band, we calculate the probabilities that the exchange rate remains within a one, two, and five percent-wide band over any given period. As with the mean absolute deviation, these probabilities are calculated over two-year and five-year rolling windows. Unless otherwise noted in Appendix II, we use the 5-year rolling windows as our primary source in the analysis. These probabilities supplement the analysis in an important manner. While pre-announced explicit exchange rate bands are not rareimplicit unannounced bands are positively commonplace.

\section{De jure and de facto pegs and bands: definition issues}

Where the chronologies show the authorities explicitly announcing a peg, we shortcut the de facto dating scheme described below and zero in on the date announced as the start of the peg. We then see if we can confirm the peg by examining the mean absolute monthly change over the period following the announcement. Obviously, the chronologies we develop, which give the day, month and year when a peg becomes operative are essential to our algorithm. There are two cases where we need to go beyond simply verifying the announced peg. The first of these is the case where our chronologies indicate that the pegged rate is only an official rate and that there is an active dual market (official or illegal). As we describe in the text, essentially, we apply the same battery of tests to the parallel market rate as we do to the official rate in a unified market. Secondly, there are the cases where policy is announced as pegging to a basket of currencies, often without disclosing of the weights or the currencies included in the basket. In these cases, we attempt look to see if the "basket" peg is really a de facto peg to a single dominant currency (or to the SDR). If no dominant currency cannot be identified, we do not label the episode as a peg. ${ }^{20}$ Potentially, of course, we may be missing some de facto basket pegs, though in practice, this is almost certainly not a major issue.

We have described our procedure for confirming de jure pegs; we now proceed to elaborate how we use our measures of exchange rate volatility to detect de facto pegs. If authorities have not announced that their currency is pegged, we test for a "de facto" peg in two manners: First, we examine the monthly absolute percent changes. If the absolute monthly percent change in the exchange rate is equal to zero for four consecutive months or more, that episode is classified (for however long its lasts) as a de facto peg if there are no dual or multiple exchange rates in place. This allows us to identify relatively short-lived de facto pegs as well as those with a longer duration. For instance, this exercise allowed us to identify the Philippines de facto peg to the US Dollar during 1995-1997 in the run-up to the Asian crisis as well as the numerous European de facto pegs to the DM well ahead of the Euro. Second, we compute the probability that the monthly exchange rate change remains within a one percent band over a rolling 5-year period

${ }^{19}$ This is a problem with the Levy-Sturzeneger (2002) reclassification strategy. For instance, in 1994 all CFA Franc Zone countries are listed as managed floating. In effect, this is the result of a one-time $100 \%$ devaluation in January of 1994.

${ }^{20}$ Pegs to the SDR are readily verifiable so they are treated in the same manner as pegs to any other currency. 
$\mathrm{P}(\varepsilon<1 \%)$.

where $\varepsilon$ is the monthly absolute percentage change in the exchange rate. If this probability is $\mathbf{8 0}$ percent or higher, then the regime is classified as a de facto peg or crawling peg over the entire 5-year period. If the exchange rate has no drift, it is classified as a fixed parity; if a positive drift is present, it is labeled a crawling peg; and, if the exchange rate also goes through periods of both appreciation and depreciation it is a moving peg. Our choice of an 80 percent threshold is not accidental, but rather we chose this value because it appears to do a very good job at detecting regimes one would want to label as pegs, without drawing in a significant number of "false positives."

Chart A.1 plots this rolling five-year probability for the US Dollar-Yen (the dashed line), for the Bolivian Peso-US Dollar (the dark solid line) and for the French Franc-DM rate (the pale solid line). The two vertical lines indicate the beginning and the end of the period during which Bolivia had an annual inflation rate above 40 percent - these inflationary episodes will be dubbed freely falling.

As is evident from Chart A.1, the probability that monthly exchange rate change falls within a $+/-1 \%$ band is far lower for the Yen-US Dollar rate than for the Bolivian peso-US Dollar rate. The period during which these rolling probabilities were declining for the Bolivian peso-US Dollar rate corresponds to the time of Bolivia's hyperinflation of the mid 1980s and its immediate aftermath. The rolling probability also captures the French Franc's strengthening ties to the DM over the course of the sample.

Our approach regarding pre-announced and de facto bands follows a parallel two-step process. If a band is explicitly announced and the chronologies show a unified exchange market, we label the episode as a band unless it had already been identified as a de facto peg by the criteria described earlier. But we also verify whether the announced and de facto bands coincide. There are several cases where the announced (de jure) band is much wider than the de facto band. ${ }^{21}$ Thus, as before, we calculate the probability that the monthly exchange rate change remains within a $+/-2 \%$ band over a rolling 5 -year period. If this probability is $\mathbf{8 0}$ percent or higher, then the regime is classified as a de facto narrow band, narrow crawling or moving band over the period through which it remains continuously above the 80 percent threshold.

Figure A.2 plots the probability that the monthly percent change in the exchange rate will be within a $+/$ $2 \%$ band for the same three bilateral exchange rates as before. The contrast between the behavior of the Dollar-Yen rate with the other two bilateral rates is now even more stark - as in both the case of the Bolivian Peso-Dollar rate and the French Franc-DM 100 percent of the observations fall within a +/-2\% band through most of the 1990 s. For the Dollar-Yen only between 45 and 60 percent of the observations fall in this narrow band.

\footnotetext{
${ }^{21}$ Mexico's exchange rate policy prior to the December 1994 crisis is one of numerous examples, despite the fact that the band was widening over time, as the floor of the band was fixed and the ceiling was crawling, the peso remained virtually pegged to the US dollar for extended periods of time.
} 
FIGURE 2. ABSOLUTE MONTHLY PERCENT CHANGE IN THE EXCHANGE RATE

PERCENT OF OBSERVATIONS WITHIN A $2 \%$ BAND

(5-YEAR MOVING AVERAGE)

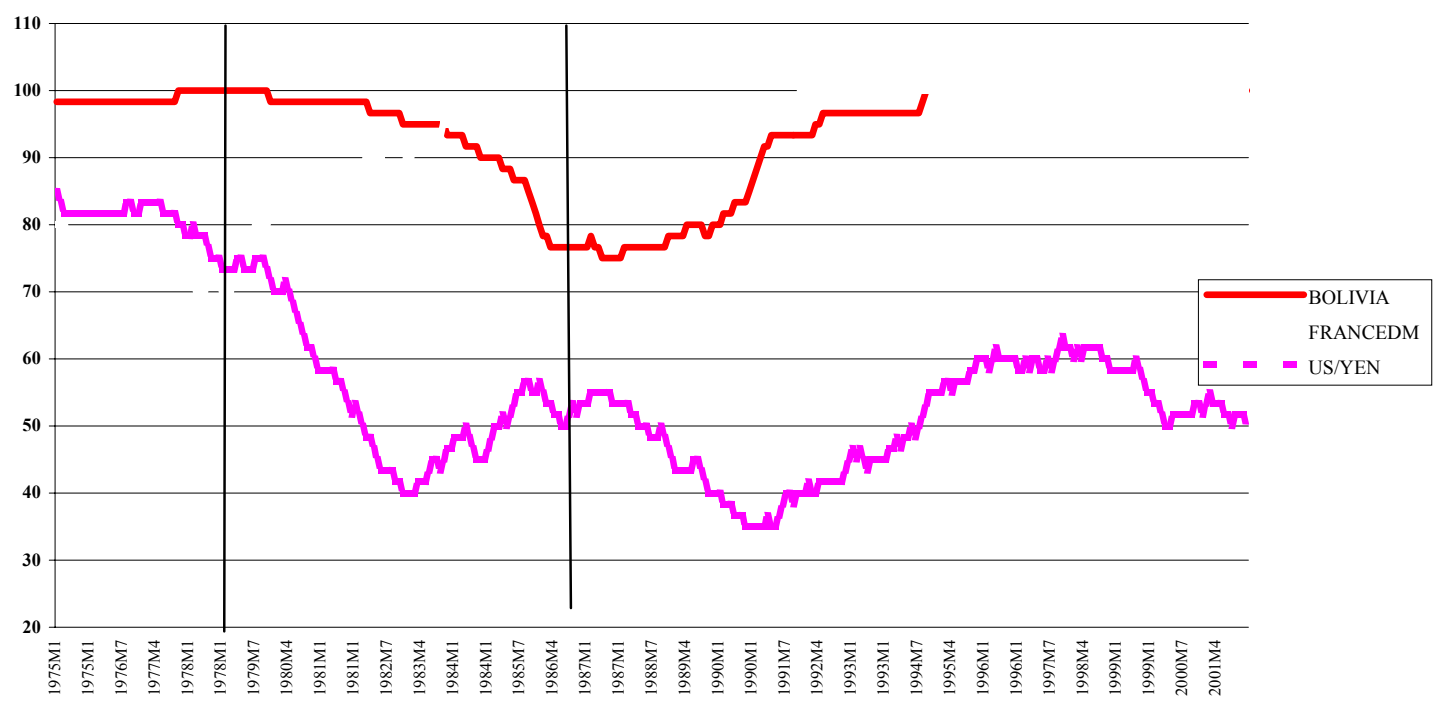

In the case where the pre-announced bands are wide we also verify $+/-5 \%$ bands. The specifics for each case are discussed in Appendix III. For instance in the case of Chile we found that the de facto band during 19921998 was narrower $(+/-5 \%)$ than that which was announced $(+/-10 \%$ and $+/-12.5 \%)$. In the case of Libya, which had an announced a $77 \%$ wide band along a fixed central parity pegged to the SDR over the March 1986-December 2001, we were able to detect a $+/-5 \%$ crawling band to the US Dollar. ${ }^{22}$

\section{The essential distinction between freely falling and freely floating}

As we emphasize in the text, there are situations, almost invariably due to high inflation, in which large downward shifts in the exchange rate occur on a routine basis for extended periods of time. Given the many wellknown problems that high inflation can cause, we believe that it is inappropriate and misleading to lump these cases in with other floating rate regimes - even though that is essentially what all previous classifications algorithms have done. ${ }^{23}$ A more apt characterization would be to label episodes as freely falling. ${ }^{24}$ To identify the freely falling episodes we rely on two criteria: First, periods where the 12-month rate of inflation equals or exceeds 40 percent are classified as freely falling unless they have been identified as some form of pre-announced peg or pre-announced narrow band by the above criteria. ${ }^{25}$ The 40 percent inflation threshold is not entirely arbitrary, as it has been

\footnotetext{
22 Though we incorporate these wider band regimes, narrow $+/-2 \%$ crawling bands are the most common. Again, our chronologies are absolutely essential to detecting these subtleties.
}

${ }^{23}$ As we shall see, many of our freely falling regimes are labeled as peg in the official and other classifications, because these earlier efforts did not employ data on parallel or dual markets.

${ }^{24}$ Our classification scheme is the first to make the fundamental distinction between floats and hyperfloats (freely falling). In previous classifications, freely falling cases are usually included in the managed or freely floating categories in the IMF's classification and also in the Levy-Yeyati and Sturzenegger (2000) scheme.

${ }^{25}$ It is critical that the peg criteria supersede the inflation criteria in the classification strategy, since historically a majority of inflation stabilization efforts have used the exchange rate as the nominal anchor and in many of these episodes inflation rates at the outset of the peg were well above our 40 percent threshold. 
identified as an important benchmark in the literature on the determinants of growth. ${ }^{26}$ In effect, as we discuss later, the average annual inflation rate for the countries that are grouped under this category is 453 percent. Borderline freely falling, which we do not classify as a separate regime, refers to inflation rates in the 20-39 percent range. We note these episodes on the commentary in Appendix II. As a special sub-category of freely falling, we include those episodes that meet Cagan's (1956) classic definition of hyperinflation (50\% or more inflation per month). We label this subcategory as hyperfloats.

A second situation where we label an exchange rate as freely falling are the six months immediately following a currency crisis - but only for those cases where the crisis marks a sudden transition from a fixed or quasi fixed regime to a managed or independently floating regime. ${ }^{27}$ Such episodes are typically characterized by exchange rate overshooting. This is another situation where a large change in the exchange rate is not obviously connected to a deliberate intent to float the currency, rather the decline is the result of a large speculative attack. To date these crisis episodes we follow a variant of the approach suggested by Frankel and Rose (1996). Namely, any month where the depreciation exceeds or equals twelve and one-half percent and also exceeds the preceding month's depreciation by at least 10 percent is identified as a crisis. ${ }^{28}$ To make sure that this approach yields plausible crisis dates, we supplement the analysis with our extensive country chronologies, which also shed light on balance of payments difficulties. ${ }^{29}$ As noted, cases where a large devaluation took place but the exchange rate was re-pegged are not included in the freely falling episodes. Again, our choice of thresholds (six months) is the one that seems to give reasonable and robust results.

Whereas the distinction between freely floating and freely falling has not been previously made in the literature, it is clearly essential if one wants to understand anything about exchange rate regimes. Table 3 shows the cumulative change in the exchange rate vis-à-vis the US dollar from January 1970 to December 2001 for selected countries. As there is great divergence across currencies' in their capacity to retain value vis-à-vis the US dollar, the figures shown in this Table A.1 anticipate which countries are candidates for having one or more episodes that come under the heading of freely falling.

\footnotetext{
${ }^{26}$ See Easterly (2001).

${ }^{27}$ This rules out cases where there was a devaluation and a re-peg and cases where the large exchange rate swing occurred in the context of an already floating rate.

${ }^{28}$ Frankel and Rose (1996) do not date the specific month of the crisis but the year and the F-R criteria calls for a twenty-five (or higher) depreciation over the year.

${ }^{29}$ For instance, the Thai crisis of July 1997 does not meet the modified Frankel-Rose criteria. While the depreciation in July exceeded that of the preceding month by more than 10 percent, the depreciation of the Thai Baht in that month did not exceed 25 percent. For these cases, we rely on the chronologies of events.
} 
Table A.1. Cumulative Change in the Currency's Value versus the US Dollar: Selected Cases, January, 1970-December, 2001

\begin{tabular}{cr}
\hline \hline Country & Cumulative percent change \\
\hline \hline Congo, Democratic Republic of & $9,924,011,976,047,800$ \\
Brazil & $124,316,767,667,574$ \\
Argentina & $2,855,714,286,430$ \\
Nicaragua & $933,784,495,428$ \\
Peru & $9,129,198,866$ \\
Bolivia & $54,040,304$ \\
Turkey & $7,500,585$ \\
Chile & $5,636,100$ \\
Mexico & 77,249 \\
Malawi & 9,512 \\
Indonesia & 2,798 \\
Egypt & 783 \\
Italy & 480 \\
Korea & 312 \\
Australia & 104 \\
United Kingdom & 64 \\
Canada & 39 \\
Malaysia & 23 \\
Panama & 0 \\
Saudi Arabia & -16 \\
Germany & -54 \\
Japan & -59 \\
Switzerland & -65 \\
\hline \hline
\end{tabular}

Source: International Monetary Fund, International Financial Statistics.

${ }^{1}$ Versus the DM.

Notes: A negative entry denotes an appreciation.

Since, as a rule, freely falling is not typically an explicit arrangement of choice, our classification also provide for all the freely falling cases, the underlying de jure or de facto arrangement (for example, dual markets, independently floating, etc.).

\section{Managed and freely floating}

In reality, "pure" floating exchange rates are an artifact of economics textbooks. Even in countries where the exchange rate is not an explicit target of policy, there are typically occasional (if relatively rare) instances where there is unilateral or coordinated intervention in the foreign exchange market. Similarly, it is hard to come up with a pure concept of "managed floating" that translates meaningfully into practice.

Our approach here to identifying managed and freely floating episodes is basically to create these classes out of the residual pool of episodes that, after comprehensive application of our algorithm, have not been identified as an explicit or implicit peg or narrow band, and that are not included in the freely falling category. To proxy the degree of exchange rate flexibility under freely floating and managed floats, we construct a composite statistic,

$\varepsilon / \mathrm{P}(\varepsilon<1 \%)$.

Here, the numerator is the mean absolute monthly percent change in the exchange rate over a rolling five-year period, while the denominator flags the likelihood of small changes. For de jure or de facto pegs, this index will be very low, while for the free falling cases it will be very large. At any rate, we only focus on this index for those countries and periods which are candidates for freely or managed floating labels. We tabulate the frequency distribution of our index for the currencies that are most transparently floating, these include: US Dollar/DM-Euro, US Dollar/Yen, US Dollar/UK Pound, US Dollar/Australian Dollar, and US Dollar/New Zealand Dollar over the 
post 1973 period (the exact subperiod for each currency can be ascertained from the chronologies). We have many of these observations, as we tabulate the ratio for rolling 5 -year averages for all the floaters. ${ }^{30}$ So, for example, Brazil floated the real in January 1999- hence, we would calculate the ratio only from that date forward. If the Brazil's ratio falls inside the 99 percent confidence interval or is in the upper tail of the distribution of the floater's group, the episode is characterized as freely floating. If that ratio falls in the lower one percent tail, the null hypothesis of freely floating is rejected in favor of the alternative hypothesis of managed float.

It is important to note that managed in this context does not necessarily imply active or frequent foreign exchange market intervention - it refers to the fact that for whatever reason our composite exchange rate variability index, $\varepsilon / \mathrm{P}(\varepsilon<1 \%)$, does not behave like the indices for the "clean" floaters (freely floating).

\section{Dual or multiple exchange rate regimes and parallel markets}

Dual rates are, possibly the most hybrid of arrangements. There are cases or periods in which the premium is nil and stable so that the official rate is representative of the underlying monetary policy. The official rate could be pegged, crawling or maintained within some bands, or in a few cases allowed to float. But there are countless episodes where the divergence between the official an parallel rate is so large, that the picture is incomplete without knowledge of what the parallel market rate is doing.

The country chronologies shown in Appendix III are critical in identifying these episodes. In the cases where dual or multiple rates are present or parallel markets are active, we focus on the market-determined rates instead of the official exchange rates. We subject the market-determined rate (dual, multiple or parallel) to the battery of tests described in the preceding sections. ${ }^{31}$ This particular category will especially re-shape how we view the 1940s to the 1960s, where about half the cases in the sample involve dual markets. Our classification scheme treats dual rates as a sister species, with a set of classifications parallel to those for unified rate.

\footnotetext{
${ }^{30}$ For instance, Australia floated on December 12, 1983, so the first five-year moving average of the ratio that we would include in the frequency distribution for the floaters would be the one ending December 1988 - since that would include only observations during the floating regime. The distribution would include all subsequent 5-year moving averages.

${ }^{31}$ There are a few such cases in the sample, where only government transactions take place at the official rate.
} 
Chart 1. Distribution of Exchange Rate Arrangements with Dual Rate Regimes as a Separate Category, 1970-2001

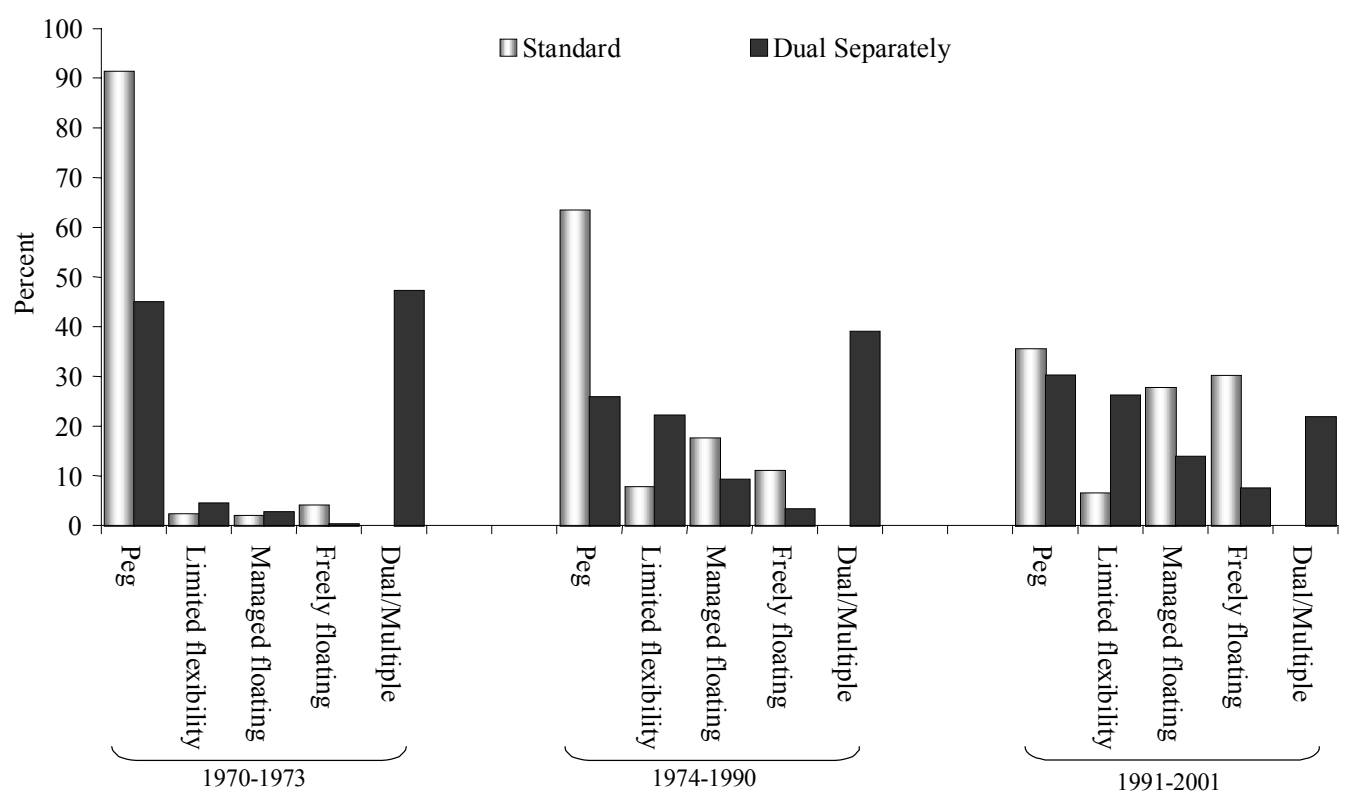

Chart 5. Distribution of Exchange Rate Arrangements According to the Standard and Natural Classifications, 1950-2001

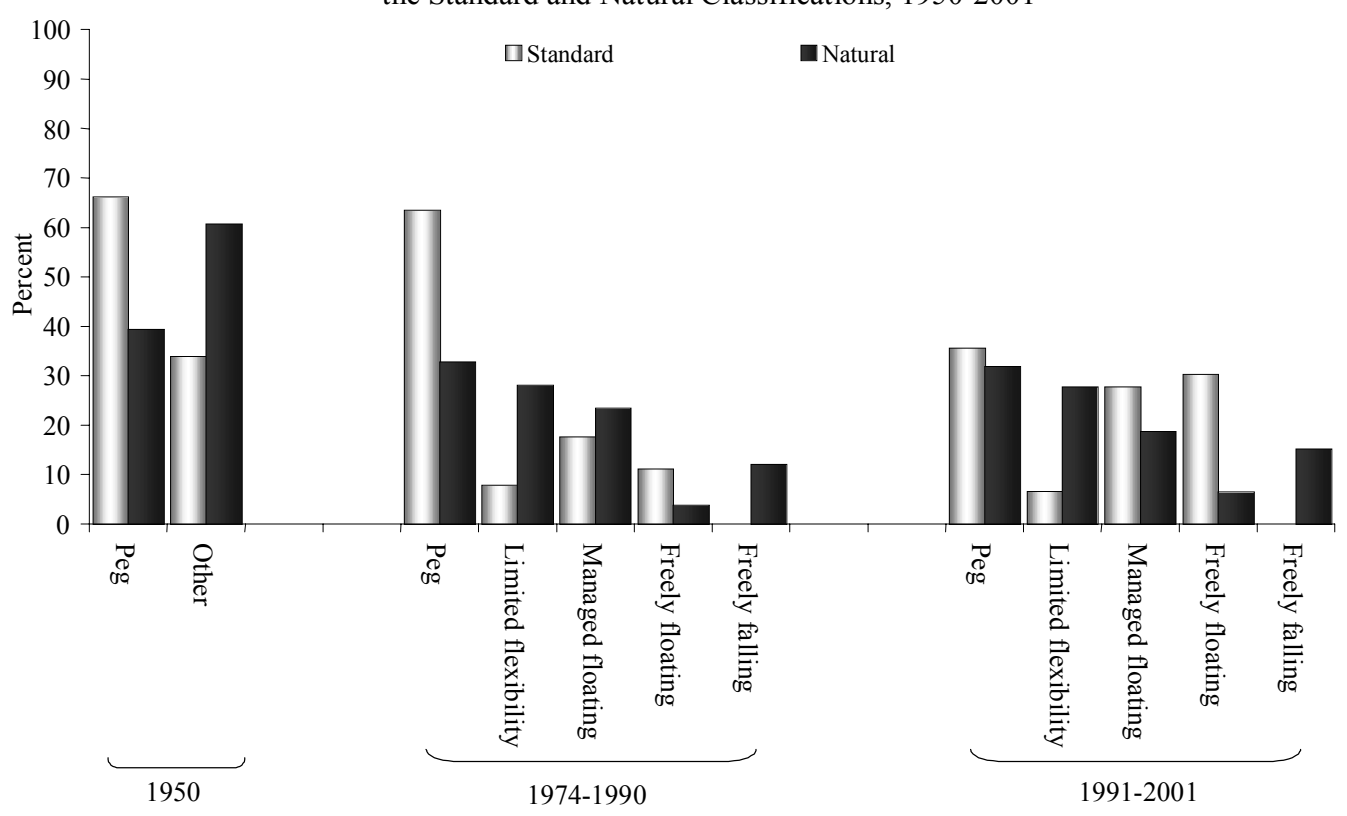

Sources: International Monetary Fund, Annual Report on Exchange Arrangements and Exchange Restrictions and International Financial Statistics, Pick and Sedillot (1971), International Currency Analysis, World Currency Report, various issues. 
Chart 2. The Essential Distinction Between Floating and Falling

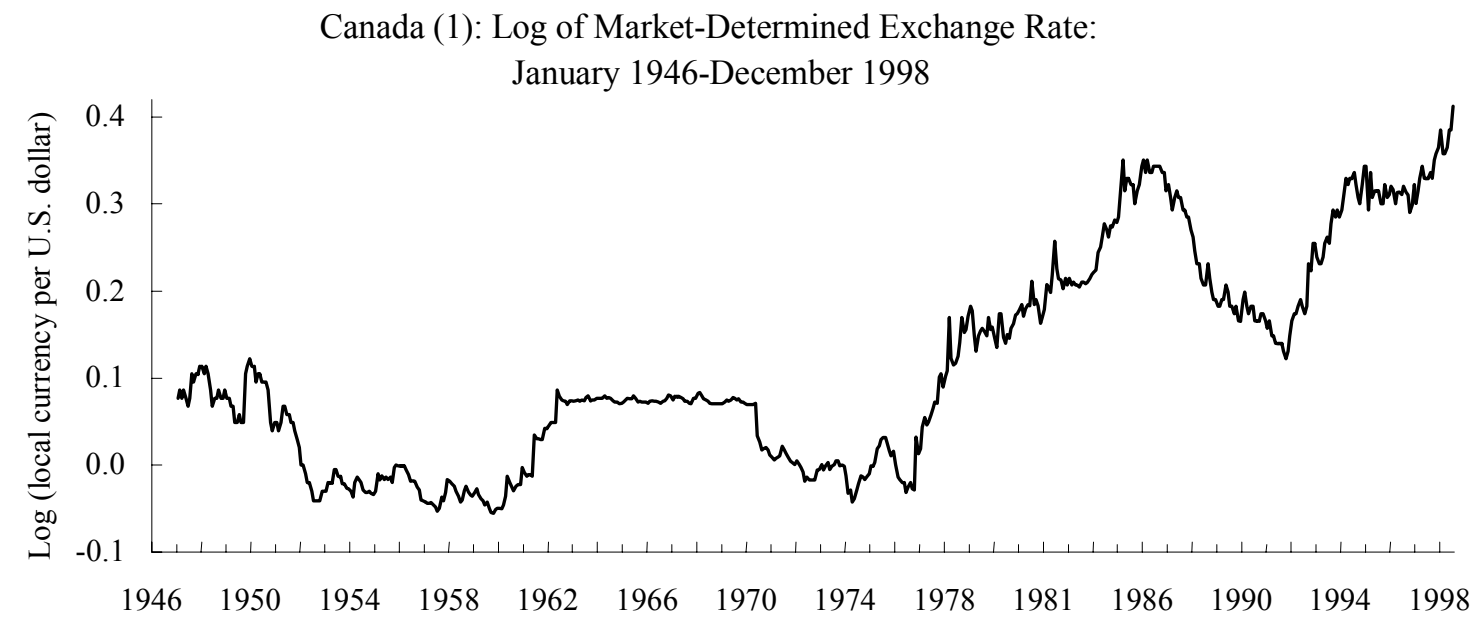

Canada (2): Log of Market-Determined Exchange Rate in Argentina's Scale: January 1946-December 1998

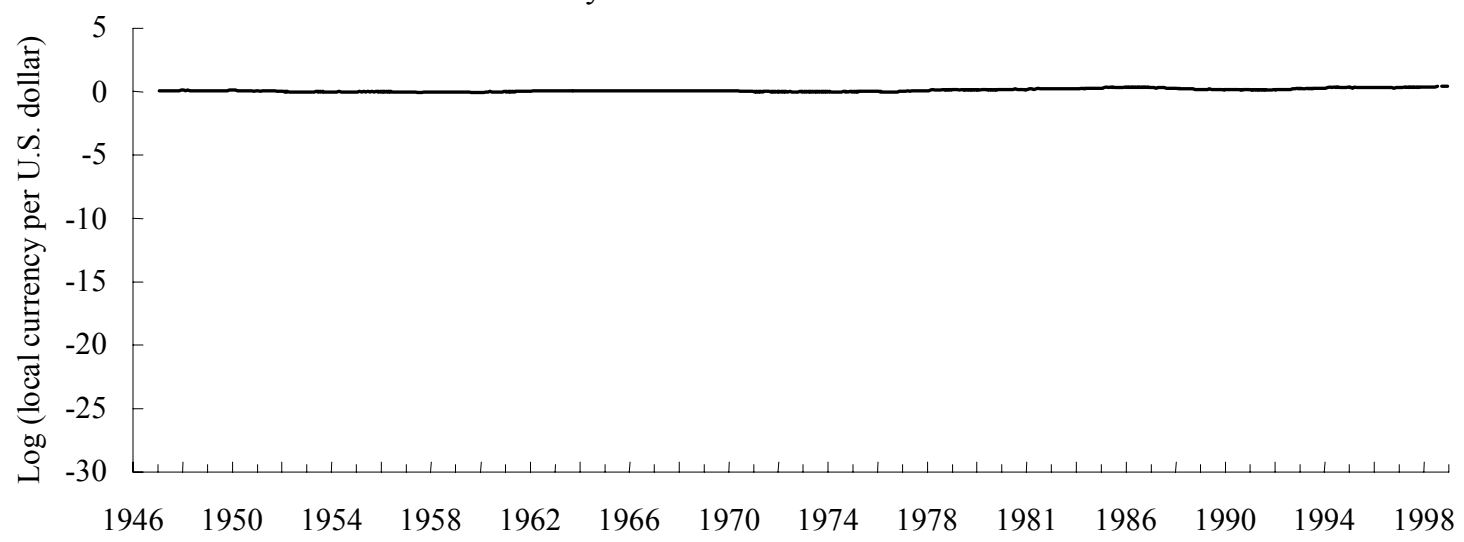

Argentina: Log of Market-Determined Exchange Rate:

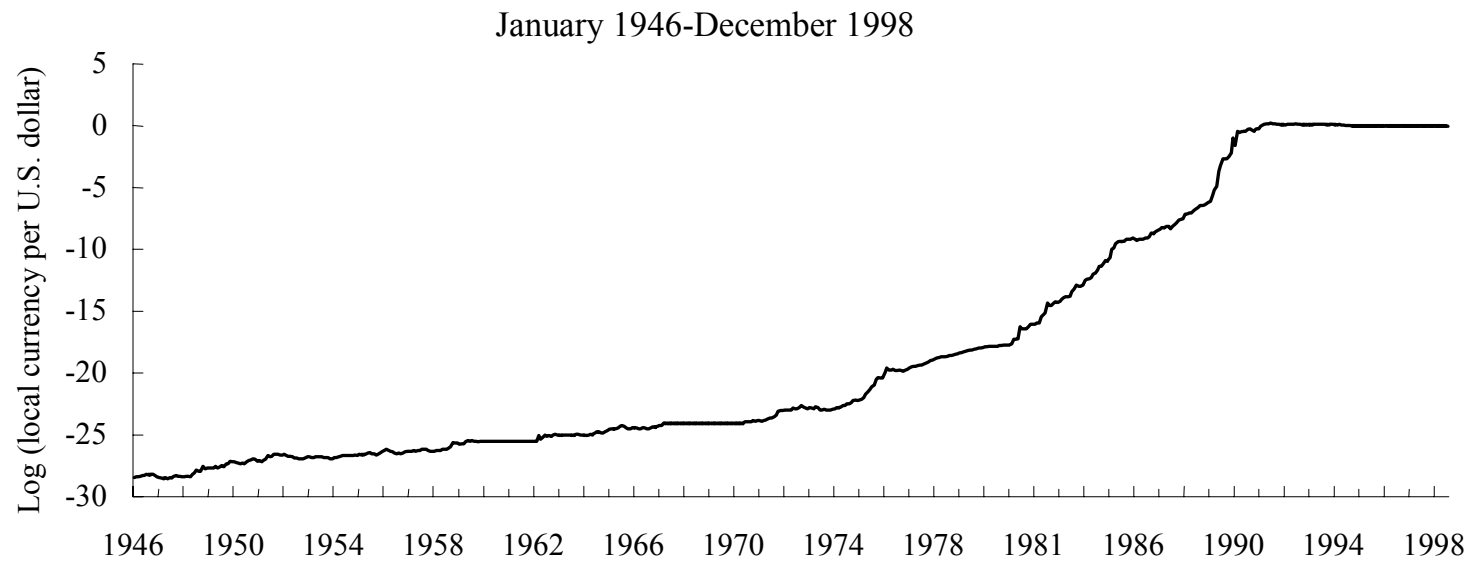

Sources: Pick's Currency Yearbook, World Currency Report, various issues. 
Chart 3. The Prevalence of Crawling Pegs and Bands

Chile: Log of Market-Determined Exchange Rate:

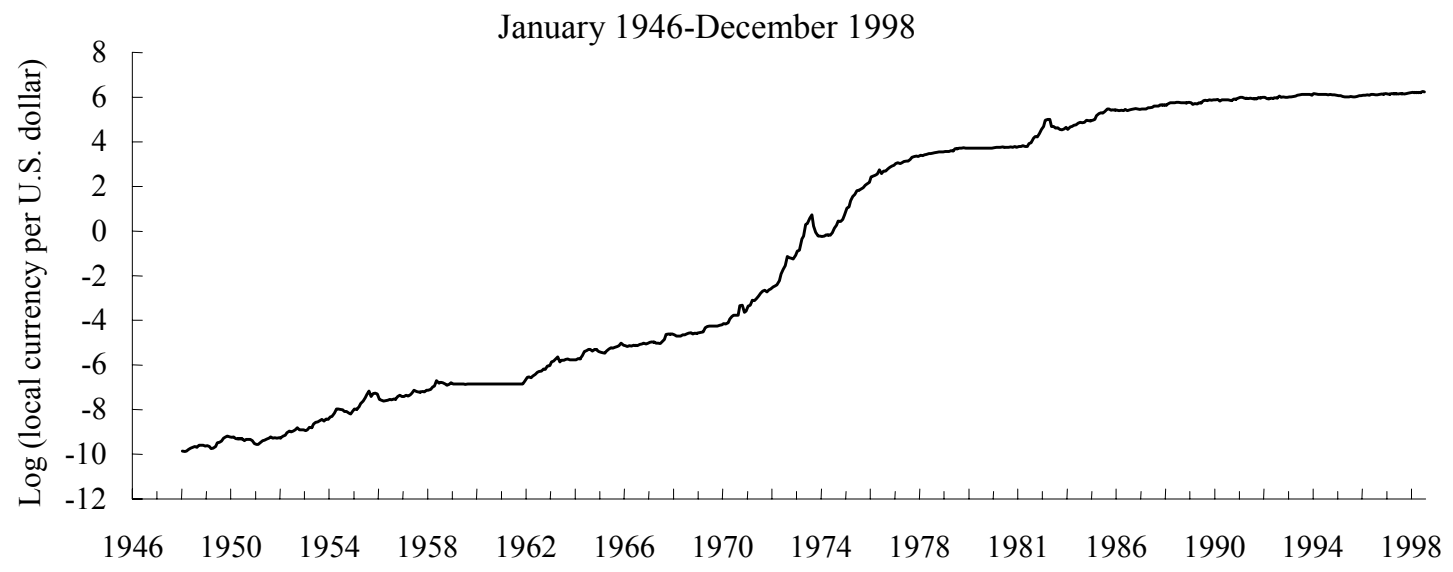

India: Log of Market-Determined Exchange Rate:

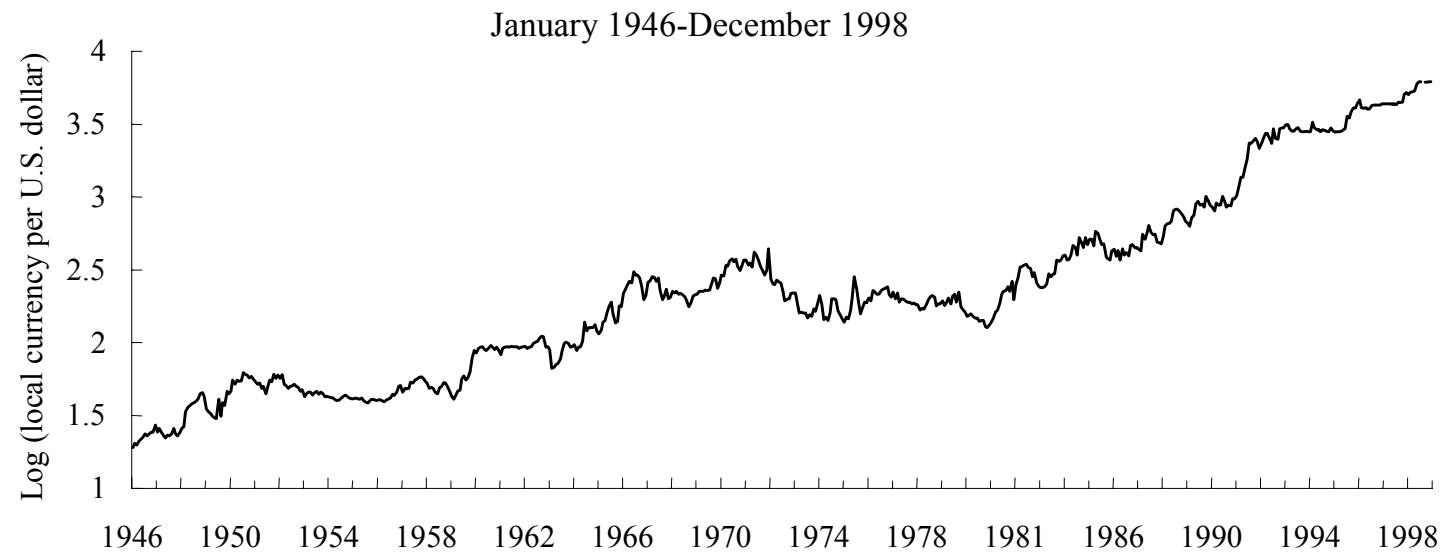

Greece: Log of Market-Determined Exchange Rate:

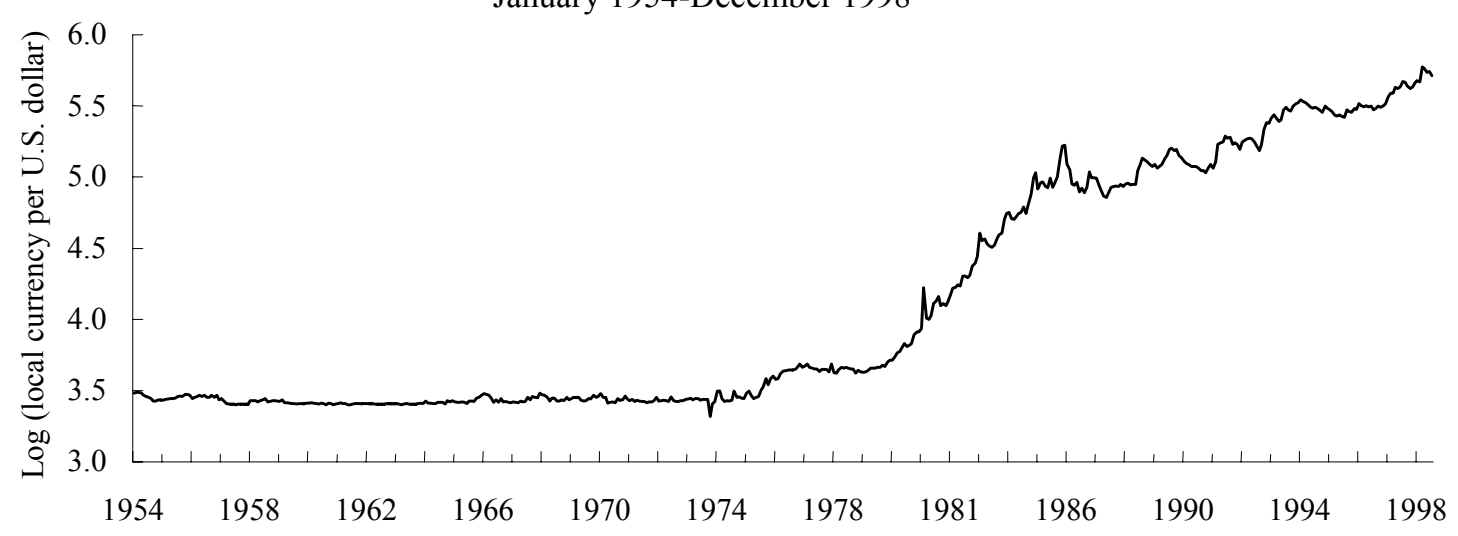

Sources: Pick's Currency Yearbook, World Currency Report, various issues. 
Chart 4. Official Exchange Rates Typically Validate the Changes in The Market Rates

$$
\text { - - - O Official — Market-Determined }
$$

Bolivia: Log of Official and Market-Determined Exchange Rates:

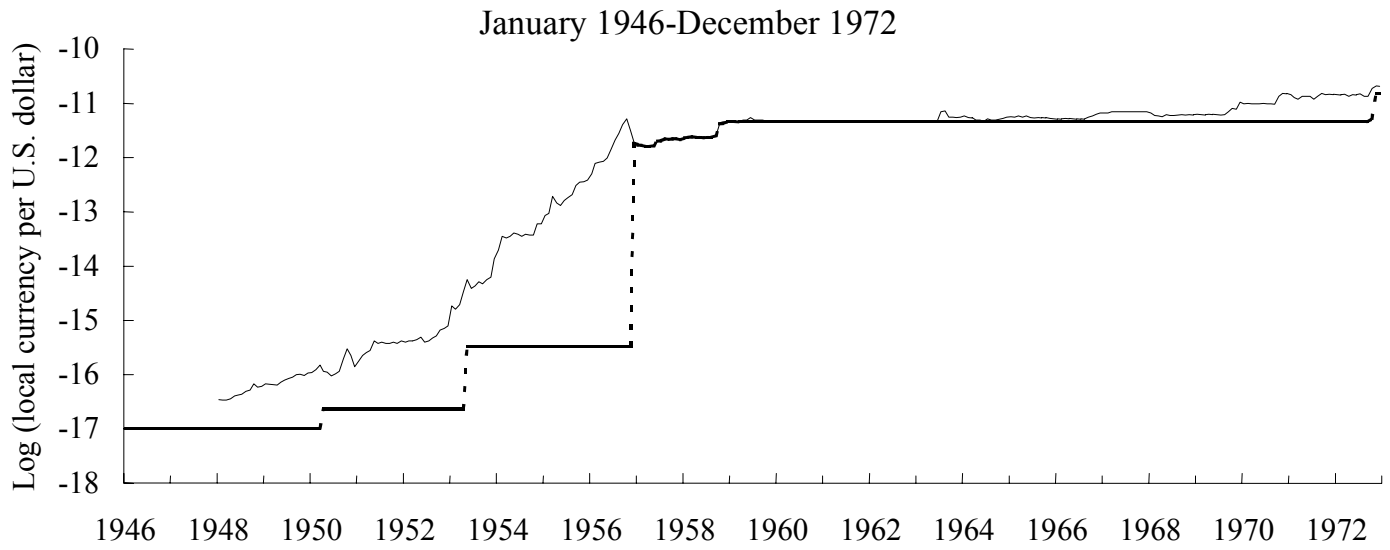

Indonesia: Log of Official and Market-Determined Exchange Rates:

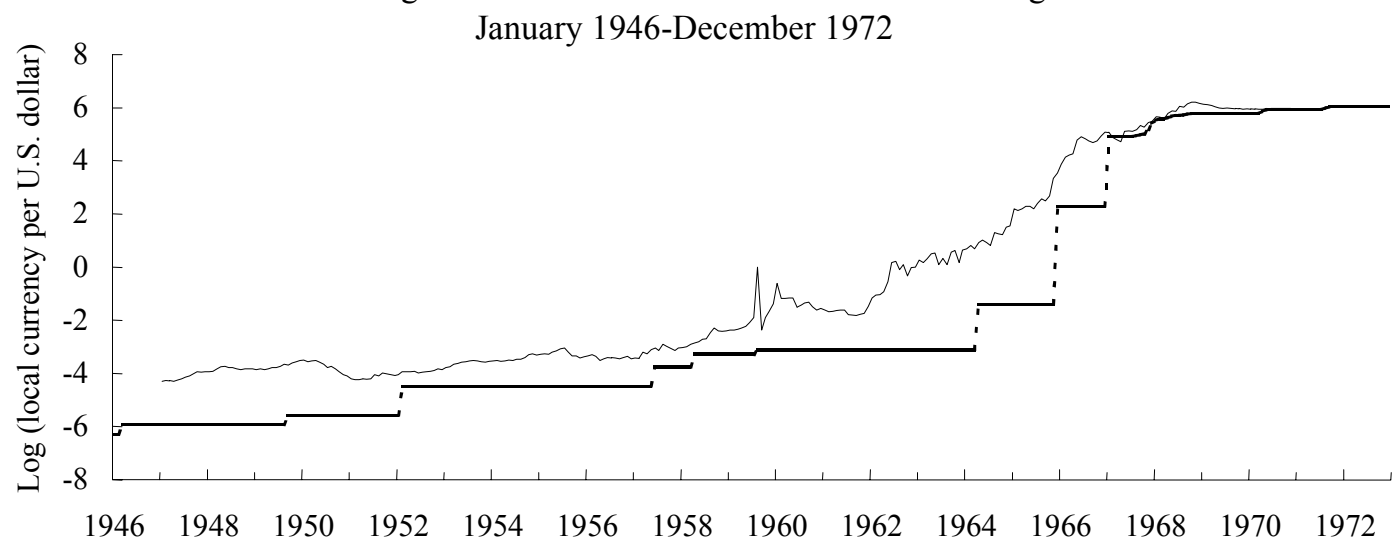

Iran: Log of Official and Market-Determined Exchange Rates: January 1946-December 1998

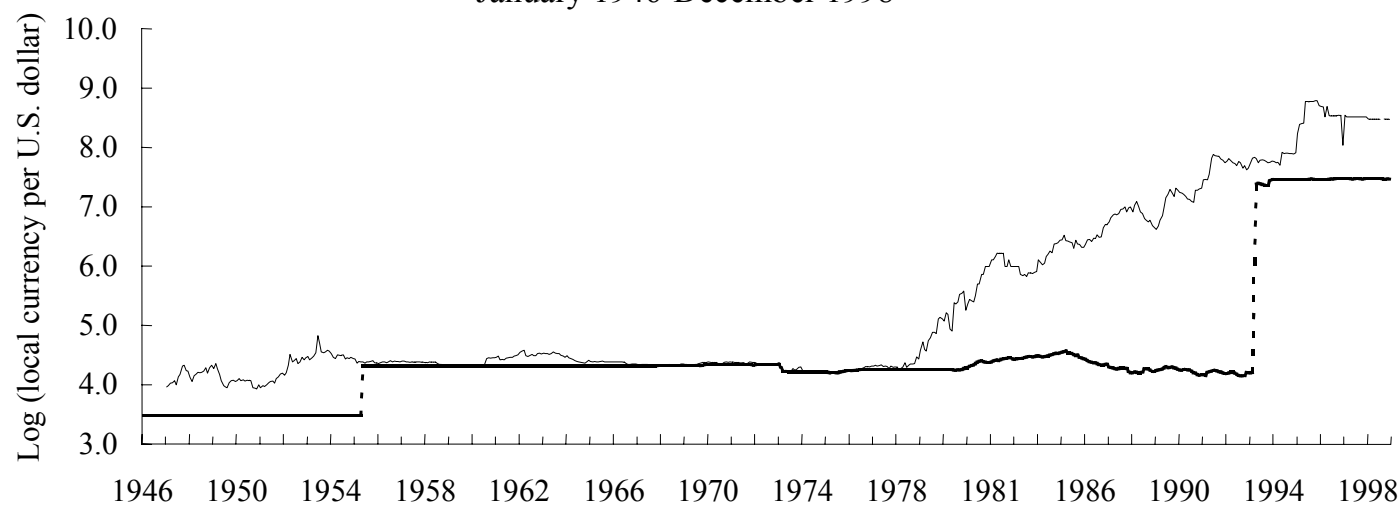

Sources: Pick's Currency Yearbook, World Currency Report, various issues. 
Chart 6. Average Monthly Parallel Market Premium: 1946-1998
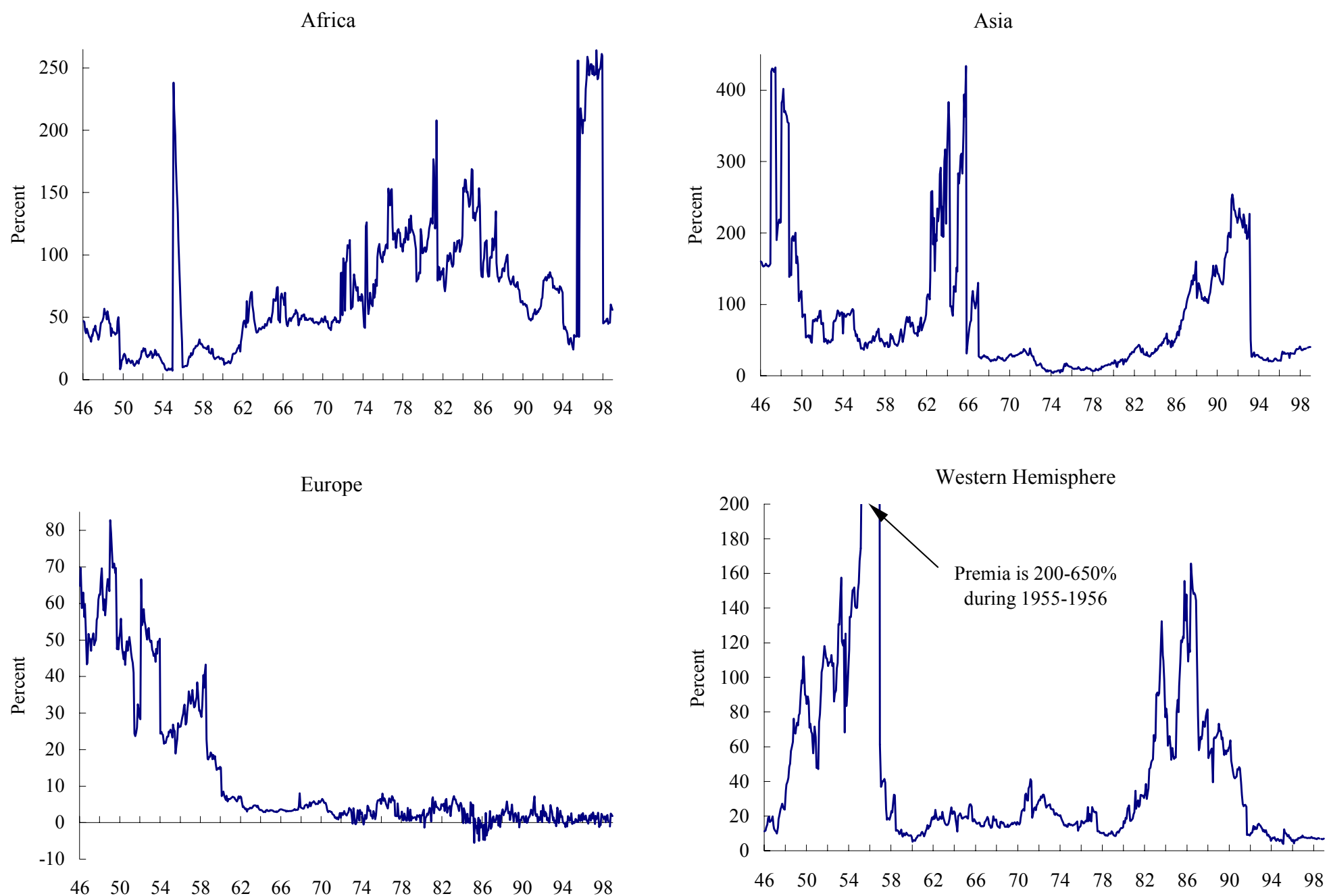

Sources: International Monetary Fund, Annual Report on Exchange Arrangements and Exchange Restrictions and International Financial Statistics, Pick and Sedillot (1971), International Currency Analysis, World Currency Report, various issues. 
Chart 7. Absolute Monthly Percent Change in the Exchange Rate: Percent of Observations within a +/- 2 Percent Band (5-year moving average)
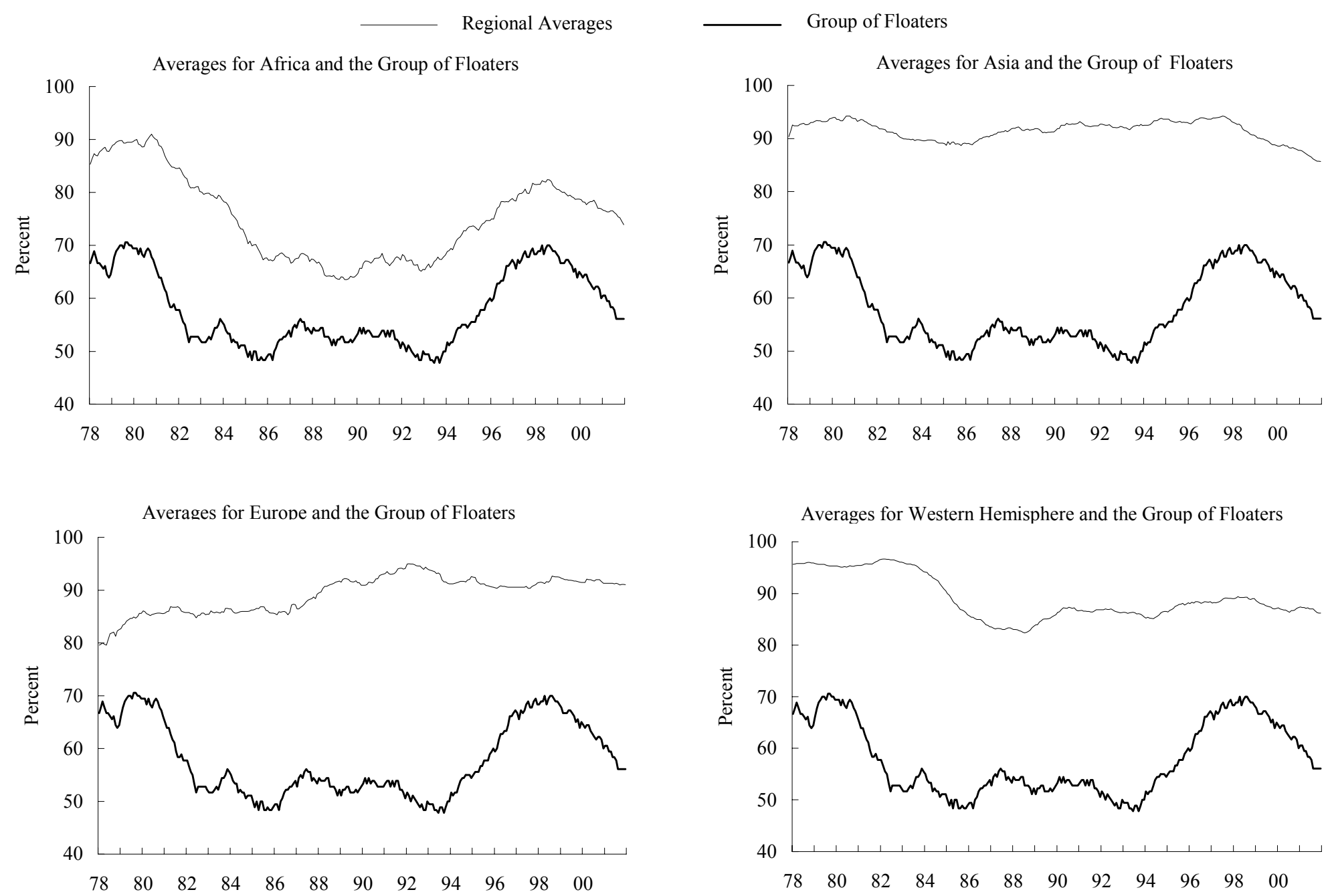

Sources: International Monetary Fund, Annual Report on Exchange Arrangements and Exchange Restrictions and International Financial Statistics, Pick and Sedillot (1971), International Currency Analysis, World Currency Report, various issues. 
Chart 8. The Cost of Having the Exchange Rate as the Nominal Anchor:

Probability of Deflation, 1970-2001

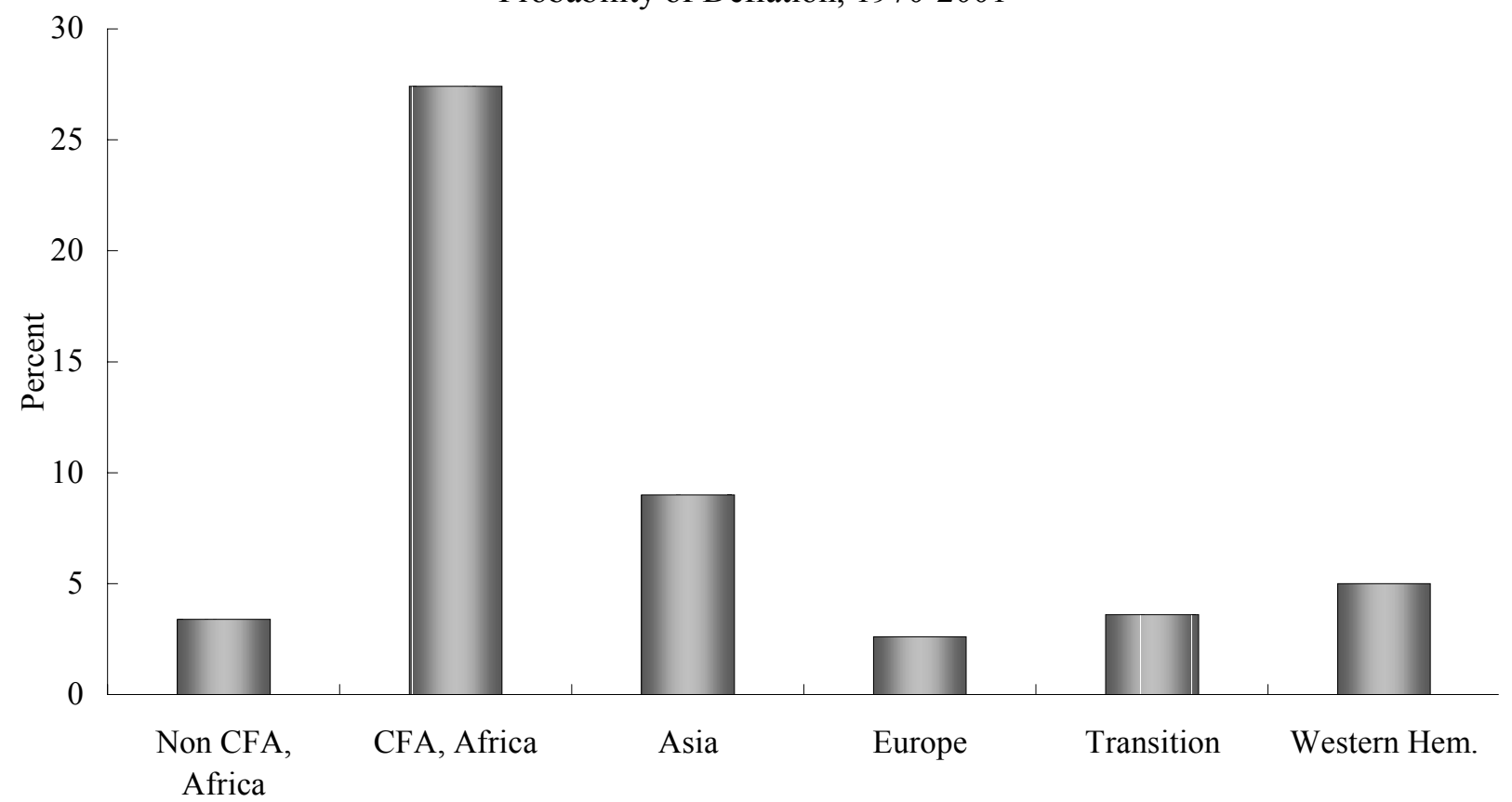

Chart 8. The Cost of Not Having a Nominal Anchor:

Probability of Freely Falling, 1970-2001

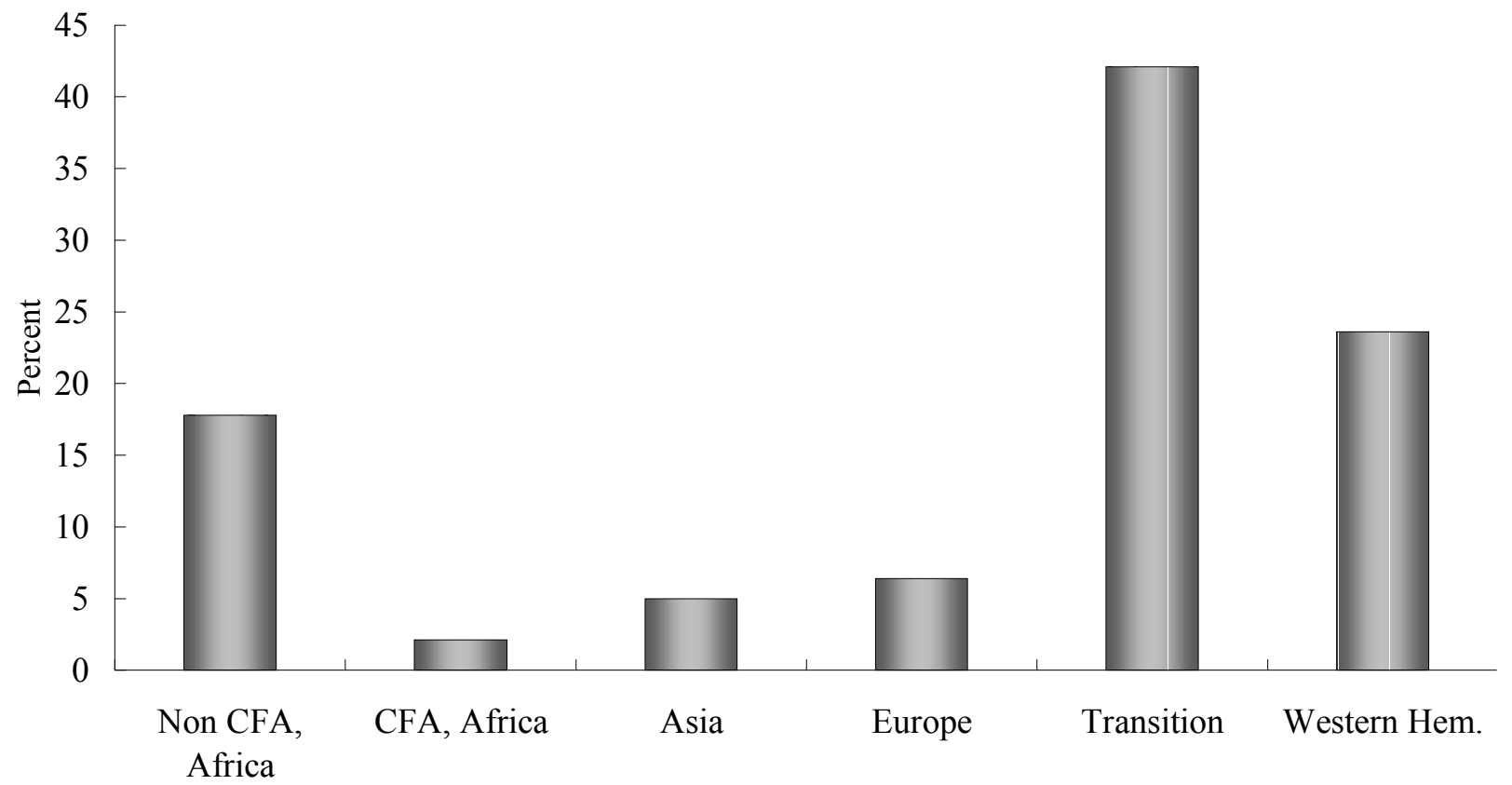

Source: IMF staff calculations. 
Chart 9. Inflation Across Regime Types: 1970 - 2001

(averaging over all regions)

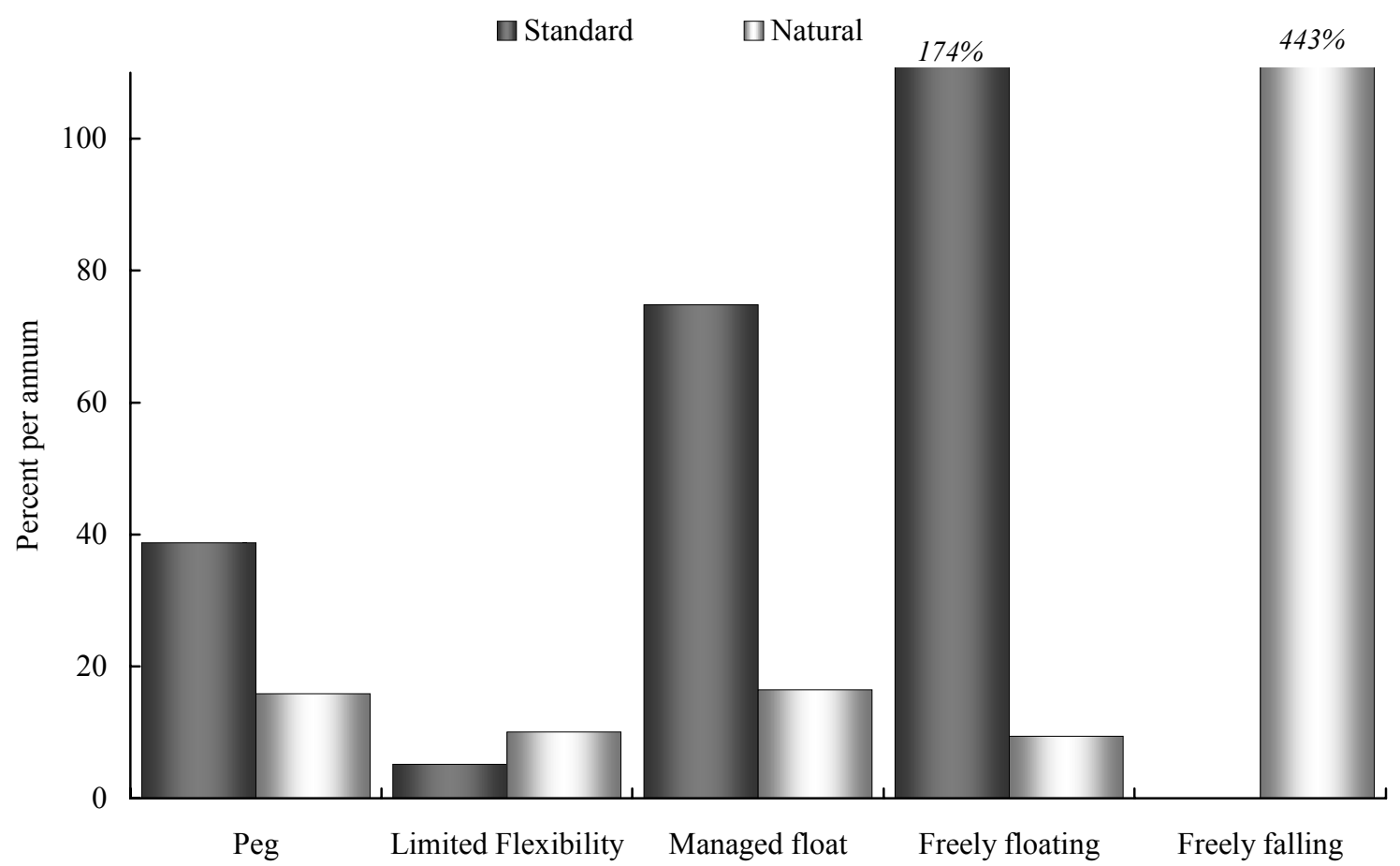

Chart 10. PPP Adjusted GDP Per Capita Across Regime Types: 1970-2001 (averaging over all regions)

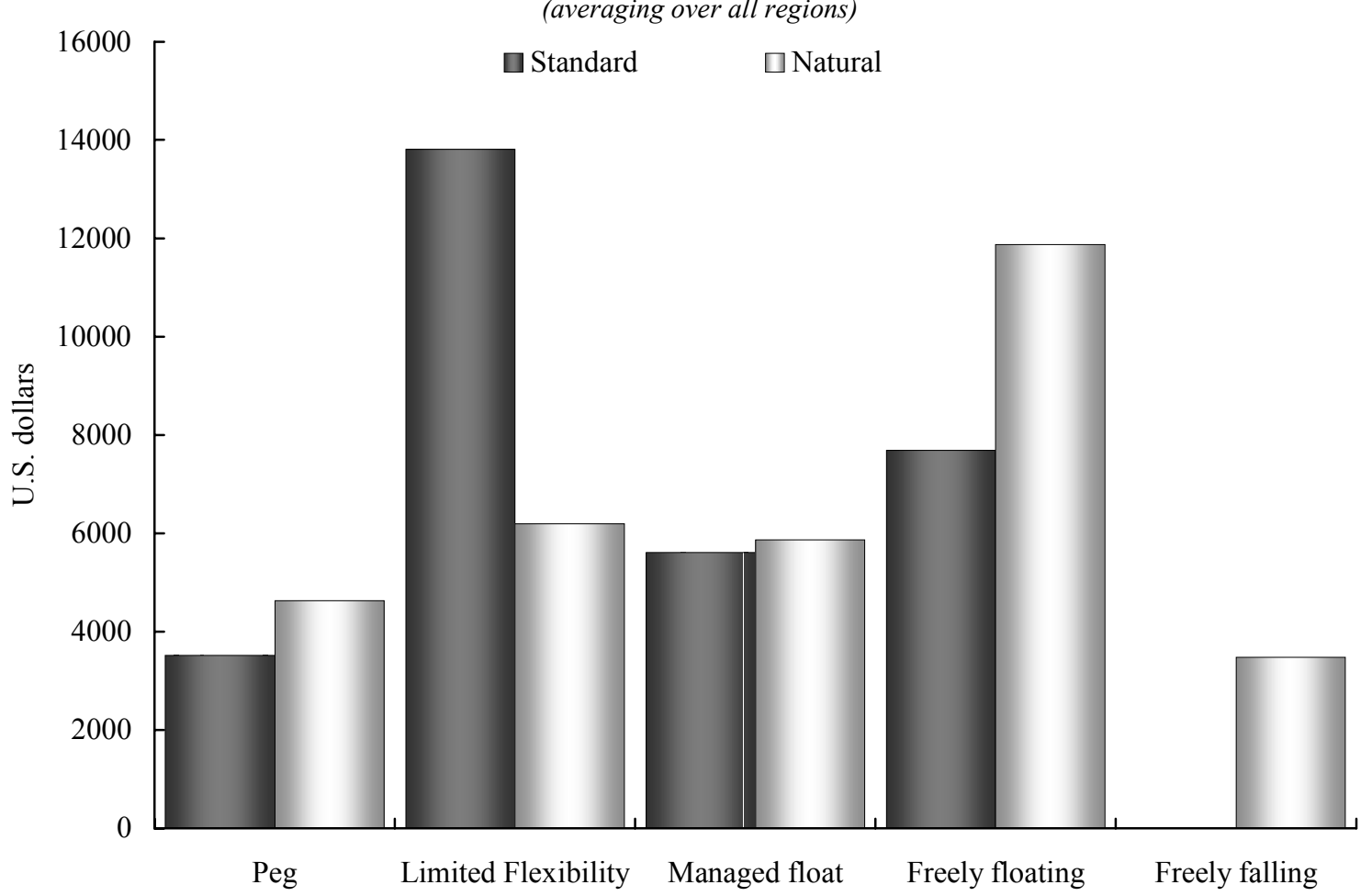

Sources: International Monetary Fund, Annual Report on Exchange Arrangements and Exchange Restrictions and International Financial Statistics, Pick and Sedillot (1971), International Currency Analysis, World Currency Report, various issues. 
Chart 11. Real Per Capita GDP Growth Across Regime Types: 1970 - 2001 (averaging over all regions)

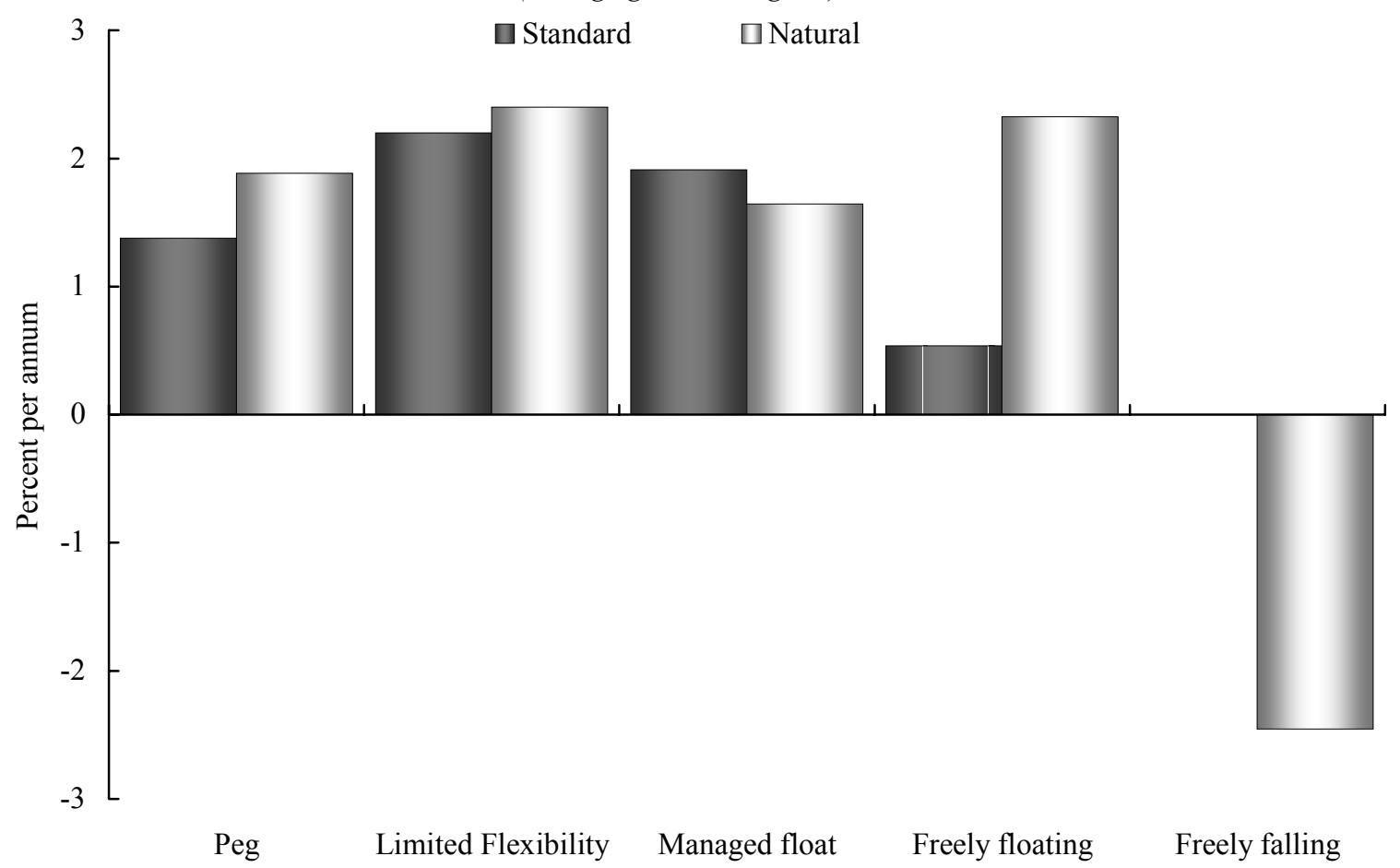

Chart 12. Exports and Imports as a Percent of GDP Across Regime Types: 1970-2001 (averaging over all regions)

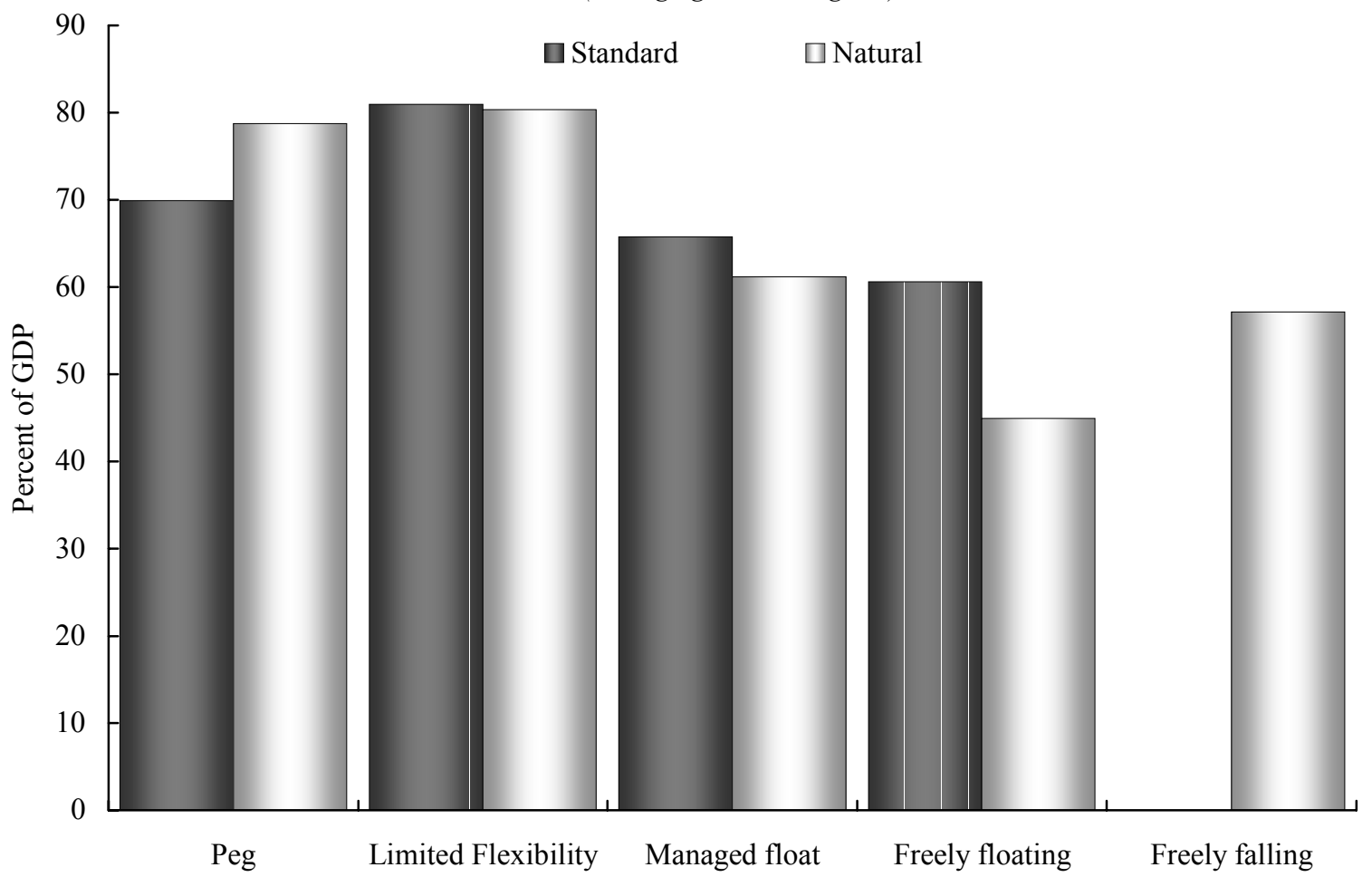

Sources: International Monetary Fund, Annual Report on Exchange Arrangements and Exchange Restrictions and International Financial Statistics, Pick and Sedillot (1971), International Currency Analysis, World Currency Report, various issues. 
This draft: May 13, 2002

\title{
Appendix III. Exchange Rate Arrangements: Country Histories
}

\author{
Carmen M. Reinhart and Kenneth S. Rogoff
}

Albania
\begin{tabular}{|l|l|l|}
\hline Date & $\begin{array}{l}\text { Classification: } \\
\text { Primary/Secondary/Tertiary }\end{array}$ & Comments \\
\hline January 1991-July 1, 1992 & Freely falling/Dual Market & Officially pegged to the ECU \\
\hline July 1, 1992-September 1993 & Freely falling/Freely floating & Markets are unified. \\
\hline October 1993-December 1996 & Freely floating & \\
\hline January 1997-January 1998 & Freely falling/Freely floating & \\
\hline February 1998-December 2001 & Freely floating & \\
\hline
\end{tabular}

Notes: Reference currencies are the US Dollar and DM.

Algeria

\begin{tabular}{|c|c|c|}
\hline Date & $\begin{array}{l}\text { Classification: } \\
\text { Primary/Secondary/Tertiary }\end{array}$ & Comments \\
\hline 1878-November 1942 & Peg to French Franc & $\begin{array}{l}\text { Algerian Franc is introduced. French Franc is legal tender } \\
\text { alongside Algerian Franc after August } 8,1920 \text {. On May } \\
20,1940 \text { foreign exchange controls are introduced. }\end{array}$ \\
\hline November 1942-December 6, 1944 & Peg to US Dollar and Pound Sterling & Incorporated into Sterling Area. \\
\hline December 6, 1944-December 1946 & Peg to French Franc & Return to Franc Zone. \\
\hline January 1947-December 1948 & Peg to French Franc/Freely falling & \\
\hline January 1949-April 10, 1964 & Peg to French Franc & \\
\hline April 10, 1964-August 1, 1972 & $\begin{array}{l}\text { Band around French Franc/Parallel } \\
\text { market }\end{array}$ & $\begin{array}{l}\text { Horizontal band, width is }+/-5 \% \text {. Dinar replaces Algerian } \\
\text { Franc. Introduction of foreign exchange controls in } 1967 . \\
\text { Parallel market premium in the } 30-70 \% \text { range. }\end{array}$ \\
\hline August 1, 1972-January 21, 1974 & Managed floating/Dual Market & Officially pegged to French Franc. \\
\hline January 21, 1974-December 1987 & $\begin{array}{l}\text { De facto crawling band around US } \\
\text { Dollar/Dual Market }\end{array}$ & $\begin{array}{l}\text { Band width is }+/-5 \% \text {. Parallel market premium reaches } \\
469 \% \text { on April } 1985 \text {. Officially pegged to a basket of } \\
\text { undisclosed currencies. }\end{array}$ \\
\hline January 1988-March 1994 & Managed floating/Parallel Market & \\
\hline April 1994-January 1995 & Freely falling/Managed floating & \\
\hline February 1995-January 1, 1999 & $\begin{array}{l}\text { De facto crawling band around French } \\
\text { Franc }\end{array}$ & Band width is $+/-2 \%$. \\
\hline January 1, 1999-December 2001 & De facto crawling band around Euro & Band width is $+/-2 \%$. \\
\hline
\end{tabular}

Notes: Reference currencies are the US Dollar, French Franc, and Euro.

Antigua and Barbuda

East Caribbean Central Bank States are: Anguilla, Antigua and Barbuda, Dominica, Grenada, Montserrat, Saint Kitts and Nevis, Saint

Lucia, Saint Vincent and the Grenadines

\begin{tabular}{|l|l|l|}
\hline Date & $\begin{array}{l}\text { Classification: } \\
\text { Primary/Secondary/Tertiary }\end{array}$ & Comments \\
\hline 1935-October 6, 1965 & Peg to Pound Sterling & $\begin{array}{l}\text { British West Indies Dollar is introduced. It is issued by the } \\
\text { East Caribbean Monetary Authority. }\end{array}$ \\
\hline October 6, 1965-July 7, 1976 & Peg to Pound Sterling & East Caribbean Dollar replaces British West Indies Dollar. \\
\hline July 7, 1976-December 2001 & Peg to US Dollar & $\begin{array}{l}\text { On October 1, 1983 the East Caribbean Central Bank } \\
\text { replaces the East Caribbean Monetary Authority. }\end{array}$ \\
\hline
\end{tabular}

Notes: Reference currency is US Dollar. 


\begin{tabular}{|c|c|c|}
\hline \multicolumn{3}{|l|}{ Argentina } \\
\hline Date & $\begin{array}{l}\text { Classification: } \\
\text { Primary/Secondary/Tertiary }\end{array}$ & Comments \\
\hline October 10, 1931-1933 & De facto peg to US Dollar & $\begin{array}{l}\text { Capital controls, convertibility into gold suspended on } \\
\text { December } 16,1929\end{array}$ \\
\hline 1933-January 20, 1934 & Peg to French Franc & \\
\hline January $20,1934-$ August 1939 & Peg to Pound Sterling & \\
\hline August 1939-June 1950 & Managed floating/Multiple rates & $\begin{array}{l}\text { US Dollar is reference currency and one rate is market } \\
\text { determined. Most transactions take place at the free rate. }\end{array}$ \\
\hline July 1950-May 1952 & $\begin{array}{l}\text { Freely falling/Managed } \\
\text { floating/Multiple rates }\end{array}$ & $\begin{array}{l}\text { US Dollar is reference currency and one rate is market } \\
\text { determined. Most transactions take place at the free rate. }\end{array}$ \\
\hline June 1952-November 1957 & Managed floating/Multiple rates & $\begin{array}{l}\text { US Dollar is reference currency and one rate is market } \\
\text { determined. Most transactions take place at the free rate. }\end{array}$ \\
\hline December 1957-March 1960 & $\begin{array}{l}\text { Freely falling-Managed } \\
\text { floating/Multiple rates }\end{array}$ & \\
\hline April 1960-March 1964 & Managed floating/Multiple rates & \\
\hline April 1964-March 13, 1967 & Peg to US Dollar & Re introduction of widespread controls \\
\hline March 13, 1967-May 1970 & Peg to US Dollar & $\begin{array}{l}\text { Inflation stabilization plan, one devaluation in June } 1970 \text {. } \\
\text { Controls were largely eliminated. Parallel premium is nil } \\
\text { during this period. }\end{array}$ \\
\hline June 1970-March 1971 & Peg to US Dollar/Freely falling & \\
\hline April 6, 1971-March 6, 1976 & $\begin{array}{l}\text { Freely falling/ Freely floating/Dual } \\
\text { Market }\end{array}$ & Parallel market premium hits $372 \%$ in November 1974. \\
\hline March 6, 1976-December 21, 1978 & Freely falling/Freely floating & Premium is consistently above $20 \%$. \\
\hline December 21, 1978-February 1981 & $\begin{array}{l}\text { Pre-announced crawling peg to US } \\
\text { Dollar/Freely falling }\end{array}$ & $\begin{array}{l}\text { The Tablita Plan. Parallel market premia is in single digits } \\
\text { during this period. }\end{array}$ \\
\hline March 1981-December 1981 & $\begin{array}{l}\text { Freely falling/Freely floating Dual } \\
\text { Market }\end{array}$ & \\
\hline January 1982-July 1982 & Freely falling/Freely floating & \\
\hline July $1982-$ June 14,1985 & $\begin{array}{l}\text { Freely falling/Freely floating/Dual } \\
\text { Market }\end{array}$ & \\
\hline June 14 1985-March, 1986 & Peg to US Dollar/Freely falling & The Austral Plan. \\
\hline April 1986-December 201990 & $\begin{array}{l}\text { Freely falling/Freely floating/Dual } \\
\text { Market }\end{array}$ & $\begin{array}{l}\text { The Austral Plan's second phase was a crawling peg which } \\
\text { lasted until September } 1986 \text { but by the then, there was a } \\
\text { dual market. For May 1989-March } 1990 \text { the regime is a } \\
\text { "hyperfloat" }\end{array}$ \\
\hline December 20, 1990-January 29, 1991 & Freely falling/Freely floating & \\
\hline January 29, 1991-March 1991 & Freely falling/Freely floating & A "Target zone"-broad band is introduced. \\
\hline April 1991-February 1992 & $\begin{array}{l}\text { Currency Board/Peg to US } \\
\text { Dollar/Freely falling }\end{array}$ & The Convertibility Plan, no adjustments to central parity. \\
\hline March 1992-December 1, 2001 & Currency Board/Peg to US Dollar & \\
\hline December 1 2001-December 2001 & De facto Dual Market & Capital controls are introduced. \\
\hline \multicolumn{3}{|c|}{$\begin{array}{l}\text { Notes: Reference currency is the US Dollar. } \\
\text { Armenia }\end{array}$} \\
\hline Date & $\begin{array}{l}\text { Classification: } \\
\text { Primary/Secondary/Tertiary }\end{array}$ & Comments \\
\hline December 31, 1991-November 1995 & $\begin{array}{l}\text { Freely falling/Freely floating/Dual } \\
\text { Market }\end{array}$ & $\begin{array}{l}\text { There is no price data before this date. Until the } \\
\text { introduction of the Dram on November 22, } 1993 \text { the } \\
\text { Russian Ruble was legal tender. } \\
\text { October 1993-December } 1994 \text { regime is a "hyperfloat" }\end{array}$ \\
\hline December 1995-December 2001 & $\begin{array}{l}\text { De facto crawling band around US } \\
\text { Dollar }\end{array}$ & Band width is $+/-2 \%$. \\
\hline
\end{tabular}

Notes: Reference currency is US Dollar. 


Australia
\begin{tabular}{|l|l|l|}
\hline Date & $\begin{array}{l}\text { Classification: } \\
\text { Primary/Secondary/Tertiary }\end{array}$ & Comments \\
\hline September 4, 1909-July 14,1915 & Peg & Gold Standard \\
\hline July 14, 1915-April 25, 1925 & Suspension of gold shipments & Gold Standard \\
\hline April 25, 1925-December 17, 1929 & Peg & $\begin{array}{l}\text { Suspension of gold standard and devaluation. Foreign } \\
\text { exchange controls introduced on August 28, 1939. }\end{array}$ \\
\hline December 17, 1929-1939 & Peg to Pound Sterling & $\begin{array}{l}\text { There is an active black market for US Dollars. Through } \\
1957 \text { the premium remains in double digits. }\end{array}$ \\
\hline 1940-February 14, 1966 & Peg to Pound Sterling & Australian Dollar replaces the Australian Pound \\
\hline February 14, 1966-December 22, 1971 & Peg Pound Sterling & $\begin{array}{l}\text { Horizontal band width is +/-2\%. Officially pegged to a } \\
\text { basket of currencies. }\end{array}$ \\
\hline December 22, 1971-September 25,1974 & Peg to US Dollar & \\
\hline October 1974-November 1982 & De facto band around US Dollar & \\
\hline November 1982-October 31, 1983 & Managed floating & \\
\hline December 12, 1983-December 2001 & Freely floating & \\
\hline
\end{tabular}

Notes: Reference currencies are the US Dollar and the Pound Sterling.

Austria

\begin{tabular}{|c|c|c|}
\hline Date & $\begin{array}{l}\text { Classification: } \\
\text { Primary/Secondary/Tertiary }\end{array}$ & Comments \\
\hline October 9,1931 & Foreign exchange controls & \\
\hline October 9, 1931-April 25, 1938 & Peg & Gold Standard, various adjustments. \\
\hline April 25, 1938-December 1945 & $\begin{array}{l}\text { Exchange rate arrangement with no } \\
\text { separate legal tender }\end{array}$ & $\begin{array}{l}\text { Reischmark is legal tender until 1945. Military exchange } \\
\text { rates are introduced in } 1945 . \text { In December the Austrian } \\
\text { Schilling is reinstated. In } 1947 \text { inflation was } 96 \% \text {. }\end{array}$ \\
\hline October 28, 1946-June 1948 & $\begin{array}{l}\text { Freely falling/Managed } \\
\text { floating/Multiple exchange rates }\end{array}$ & $\begin{array}{l}\text { Adoption of military exchange rates for commercial } \\
\text { transactions. Parallel market premium hits } 1,150 \% \text { in } \\
\text { November } 1947 \text {. Exchange controls are tightened on July } \\
25,1946 \text {. }\end{array}$ \\
\hline July 1949-July 1950 & $\begin{array}{l}\text { Managed floating/Multiple exchange } \\
\text { rates }\end{array}$ & \\
\hline August 1950 -October 6,1950 & $\begin{array}{l}\text { Freely falling/Managed } \\
\text { floating/Multiple exchange rates }\end{array}$ & \\
\hline October 6, 1950-August 1951 & $\begin{array}{l}\text { Freely falling/Managed floating/Dual } \\
\text { Market }\end{array}$ & $\begin{array}{l}\text { Parallel market premium remains in two digits throughout } \\
\text { this period. }\end{array}$ \\
\hline September 1951-May 4, 1953 & Managed floating/Dual Market & $\begin{array}{l}\text { Parallel market premium remains in two digits throughout } \\
\text { this period. }\end{array}$ \\
\hline May 4, 1953-February 17, 1959 & Peg to US Dollar & Black market dealings come to an end in late 1950s. \\
\hline February $17,1959-$ August 24,1971 & Peg to DM & \\
\hline August 24, 1971-July 1980 & De facto moving peg to DM & \\
\hline December 31, 1998-January 1, 1999 & De facto peg to DM & $\begin{array}{l}\text { March } 1991 \text { registers as a currency crash versus US } \\
\text { dollar-none versus DM. }\end{array}$ \\
\hline January 1, 1999-December 2001 & Currency union & Euro \\
\hline
\end{tabular}

Notes: Specifics on the common margins (snake) agreement, EMS, etc. are available from the detailed chronologies. Reference currencies are the US Dollar, the Euro and the DM.

Azerbaijan

\begin{tabular}{|l|l|l|}
\hline Date & $\begin{array}{l}\text { Classification: } \\
\text { Primary/Secondary/Tertiary }\end{array}$ & Comments \\
\hline December 31, 1992-January 1996 & $\begin{array}{l}\text { Freely falling/Freely floating/Dual } \\
\text { Market }\end{array}$ & $\begin{array}{l}\text { There is no price data before this date. December 1992- } \\
\text { December 1994 regime is a "hyper float." }\end{array}$ \\
\hline February 1996-December 2001 & De facto crawling peg to US dollar & \\
\hline
\end{tabular}

Reference currencies are the US Dollar and the Ruble.

Belarus

\begin{tabular}{|l|l|l|}
\hline Date & $\begin{array}{l}\text { Classification } \\
\text { Primary/Secondary/Tertiary }\end{array}$ & Comments \\
\hline August 25,1991-February 3, 1997 & $\begin{array}{l}\text { Freely falling/Freely floating/Multiple } \\
\text { rates }\end{array}$ & There is no price data before this date. \\
\hline February 3, 1997-March 31, 1998 & Freely falling/Freely floating & \\
\hline March 31, 1998-December 2001 & Freely falling/Freely floating & There are multiple rates. \\
\hline
\end{tabular}

Reference currencies are the US Dollar and the Ruble. 
Belgium

\begin{tabular}{|l|l|l|}
\hline Date & $\begin{array}{l}\text { Classification: } \\
\text { Primary/Secondary/Tertiary }\end{array}$ & Comments \\
\hline October 25, 1926-March 18, 1935 & Peg & Gold Standard \\
\hline March 18, 1935-March 31, 1936 & $\begin{array}{l}\text { Foreign exchange controls and } \\
\text { suspension of convertibility }\end{array}$ & Gold Standard \\
\hline March 31, 1936-May 10, 1940 & Peg & Capital controls \\
\hline May 10, 1940-October 5, 1944 & Peg to Reichsmark & $\begin{array}{l}\text { Officially pegged to US Dollar. The official foreign } \\
\text { exchange market was re opened on November 1949, after } \\
\text { this the parallel market premium fell to single digits. }\end{array}$ \\
\hline October 5, 1944- April 1954 & Managed floating/Parallel market & \\
\hline April 1954-July 18, 1955 & Peg to US Dollar & Small parallel market premium. \\
\hline July 18,1955-October 1971 & De facto peg to DM/Dual Market & \\
\hline November 1971-March 5, 1990 & De facto peg to DM/Dual Market & Euro \\
\hline March 5, 1990-December 31, 1998 & De facto peg to DM & Currency union \\
\hline January 1, 1999-December 2001 & S & \\
\hline
\end{tabular}

Notes: Specifics on the common margins (snake) agreement, EMS, etc. are available from the detailed chronologies. Reference currencies are US Dollar, DM, and Euro

Benin

Central Bank of West African States: Benin, Burkina Faso, Cote D'Ivoire, Guinea-Bissau, Mali, Niger, Senegal, and Togo ${ }^{1}$

\begin{tabular}{|l|l|l|}
\hline Date & $\begin{array}{l}\text { Classification: } \\
\text { Primary/Secondary/Tertiary }\end{array}$ & Comments \\
\hline June 29, 1901-February 2, 1943 & Peg to French Franc & $\begin{array}{l}\text { Banque de 1'Afrique Occidentale is allowed to issue bank } \\
\text { notes. Exchange controls are introduced within Franc zone } \\
\text { on September 9, 1939. }\end{array}$ \\
\hline February 2, 1943- December 26. 1945 & Peg to US Dollar and Pound Sterling & On December 1942 incorporated in the Sterling Area. \\
\hline December 26. 1945-May 12, 1962 & Peg to French Franc & Return to Franc Zone. The CFA Franc is introduced. \\
\hline May 12, 1962-September 9, 1971 & Peg to French Franc & Creation of the Central Bank of West African States \\
\hline September 9, 1971-March 21, 1974 & $\begin{array}{l}\text { De facto peg to French Franc/Dual } \\
\text { Market }\end{array}$ & The premium is in low single digits. \\
\hline March 21, 1974-December 1993 & Peg to French Franc & \\
\hline January 1994-December 1994. & Peg to French Franc/Freely falling & One 100\% devaluation. \\
\hline January 1995-January 1, 1999 & Peg to French Franc & \\
\hline January 1, 1999-December 2001 & Peg to Euro & \\
\hline
\end{tabular}

${ }^{1}$ Mali joined the currency arrangement at a later date.

Notes: Formerly Dahomey. Reference currencies are the French Franc and the Euro.

Bolivia

\begin{tabular}{|c|c|c|}
\hline Date & $\begin{array}{l}\text { Classification: } \\
\text { Primary/Secondary/Tertiary }\end{array}$ & Comments \\
\hline July $11,1928-$ October 3,1931 & Peg & Gold Standard \\
\hline October 3, 1931-January 1938 & Multiple rates & $\begin{array}{l}\text { The Boliviano is linked to Pound Sterling. Capital controls } \\
\text { are introduced and the gold standard is abandoned }\end{array}$ \\
\hline 1940-October 20, 1947 & Peg to US Dollar & \\
\hline October 20, 1947-December 1949 & Managed floating/Multiple rates & \\
\hline January 1950-April 1951 & $\begin{array}{l}\text { Freely falling/ Managed } \\
\text { floating/Multiple rates }\end{array}$ & \\
\hline May 1951-March 1952 & Managed floating/Multiple rates & Official rate is inoperative by mid $1950 \mathrm{~s}$ \\
\hline April 1952-November 1957 & $\begin{array}{l}\text { Freely falling/Managed } \\
\text { floating/Multiple rates }\end{array}$ & \\
\hline December 1957-February 1971 & $\begin{array}{l}\text { De facto crawling band around US } \\
\text { Dollar/Multiple rates }\end{array}$ & $\begin{array}{l}\text { Band width is }+/-2 \% \text {. On January } 1,1963 \text { the Peso replaces } \\
\text { the Boliviano. }\end{array}$ \\
\hline March 1971-September 1972 & Managed floating/Multiple rates & The official rate is pegged to US Dollar. \\
\hline October 1972-December, 1974 & Freely falling/Managed floating & The official rates are pegged to US Dollar \\
\hline January 1975-November 1979 & Managed floating/Multiple rates & $\begin{array}{l}\text { The official rate is pegged to US Dollar - there are frequent } \\
\text { mega devaluations. }\end{array}$ \\
\hline December 1979-March 24, 1982 & $\begin{array}{l}\text { Freely falling/Freely floating/Multiple } \\
\text { rates }\end{array}$ & The official rates remain pegged to US Dollar. \\
\hline March 24, 1982-August 29, 1985 & $\begin{array}{l}\text { Freely falling/Freely floating/Dual } \\
\text { Market }\end{array}$ & $\begin{array}{l}\text { The parallel market premium hits 2,023 \% in August } 1985 . \\
\text { April 1984-September } 1985 \text { regime is a "hyperfloat." }\end{array}$ \\
\hline August 29 1985-December, 1986 & $\begin{array}{l}\text { Freely falling/Freely floating/Dual } \\
\text { Market }\end{array}$ & Markets are temporarily unified. \\
\hline November 1987-December 1991 & $\begin{array}{l}\text { De facto crawling band around US } \\
\text { Dollar/Dual Market }\end{array}$ & Band width is $+/-2 \%$. \\
\hline January 1992-December 1994 & $\begin{array}{l}\text { De facto crawling peg to US } \\
\text { Dollar/Dual Market }\end{array}$ & Parallel market premium is trivial. \\
\hline January 1995-December 2001 & De facto crawling peg to US Dollar & \\
\hline
\end{tabular}

Notes: Reference currency is the US Dollar. 
Bosnia-Herzegovina

\begin{tabular}{|l|l|l|}
\hline Date & $\begin{array}{l}\text { Classification } \\
\text { Primary/Secondary/Tertiary }\end{array}$ & Comments \\
\hline July 1994-June 22,1998 & Peg to DM & $\begin{array}{l}\text { Bosnian Dinar is introduced in July 1994. Electronic } \\
\text { payments for the Bosnia-Herzegovina convertible Marka } \\
\text { ares introduced on August 12, 1997 }\end{array}$ \\
\hline June 22,1998-January 1, 1999 & Currency board/Peg to DM & Convertible Marka notes are introduced. \\
\hline January 1, 1999-December 2001 & Currency board/Peg to Euro & \\
\hline
\end{tabular}

Notes: Reference currencies are the Euro and the DM.

Botswana

\begin{tabular}{|c|c|c|}
\hline Date & $\begin{array}{l}\text { Classification } \\
\text { Primary/Secondary/Tertiary }\end{array}$ & Comments \\
\hline 1920-February 14,1961 & $\begin{array}{l}\text { Exchange rate arrangement with no } \\
\text { separate legal tender }\end{array}$ & South Africa Pound is introduced, Rand Monetary Area. \\
\hline February 14, 1961-August 23, 1976 & $\begin{array}{l}\text { Exchange rate arrangement with no } \\
\text { separate legal tender }\end{array}$ & South African Rand replaces Pound as the legal tender. \\
\hline August 23, 1976-December 1, 1976 & Peg to South African Rand & $\begin{array}{l}\text { The Pula is introduced and Botswana withdraws from Rand } \\
\text { Monetary Area. }\end{array}$ \\
\hline December 1, 1976-June 3, 1980 & Peg to US Dollar & Two devaluations. \\
\hline June 3, 1980-April 1982 & $\begin{array}{l}\text { De facto crawling peg to South } \\
\text { African Rand }\end{array}$ & Official peg to a basket of SDR and South African Rand. \\
\hline May 1982-June 1986 & $\begin{array}{l}\text { De facto crawling band around South } \\
\text { African Rand }\end{array}$ & Band width is $+/-2 \%$. \\
\hline July 1986-January 1996 & $\begin{array}{l}\text { De facto crawling peg to South } \\
\text { African Rand }\end{array}$ & $\begin{array}{l}\text { There is a parallel market with premium oscillating } \\
\text { between single digits and } 30 \% \text {. }\end{array}$ \\
\hline January 1996-August 1998 & $\begin{array}{l}\text { De facto crawling peg to South } \\
\text { African Rand/Dual Market }\end{array}$ & Premium is in single digits throughout most of this period. \\
\hline September 1998-December 2001 & $\begin{array}{l}\text { De facto crawling band around South } \\
\text { African Rand/Dual Market }\end{array}$ & Band width is $+/-2 \%$. \\
\hline
\end{tabular}

Notes: Reference currencies are the South African Rand, the US Dollar, and the SDR.

Brazil

\begin{tabular}{|c|c|c|}
\hline Date & $\begin{array}{l}\text { Classification } \\
\text { Primary/Secondary/Tertiary }\end{array}$ & Comments \\
\hline May 18,1931 & Foreign Exchange controls & \\
\hline November 21, 1933-November 1, 1942 & Multiple exchange rates & \\
\hline November 1, 1942-July 22, 1946 & Multiple exchange rates & The Cruzeiro is introduced to replace the Milreis. \\
\hline July 22, 1946-May 1947 & Peg to US Dollar/Freely falling & Unified rate \\
\hline June 1947-October 1949 & Peg to US Dollar & \\
\hline October 1949-October 1960 & $\begin{array}{l}\text { Managed floating/Multiple exchange } \\
\text { rates }\end{array}$ & $\begin{array}{l}\text { The official rate is pegged to the US Dollar but there are } \\
\text { large and frequent devaluations. }\end{array}$ \\
\hline November 1960-November 1966 & $\begin{array}{l}\text { Freely falling/Managed } \\
\text { floating/Multiple exchange rates }\end{array}$ & $\begin{array}{l}\text { The official rate is pegged to the US Dollar but there are } \\
\text { large and frequent devaluations. }\end{array}$ \\
\hline December 1966-August 271968 & $\begin{array}{l}\text { Managed floating/Multiple exchange } \\
\text { rates }\end{array}$ & $\begin{array}{l}\text { The official rate is pegged to the US Dollar but there are } \\
\text { large and frequent devaluations. An inflation stabilization } \\
\text { plan begins in March } 1964 \text {. However, the intense activity in } \\
\text { the parallel market scores as managed floating. }\end{array}$ \\
\hline August, 27,1968-March 1975 & $\begin{array}{l}\text { De facto crawling band around US } \\
\text { Dollar/Multiple rates }\end{array}$ & $\begin{array}{l}\text { Band width is }+/-5 \% \text {. A crawling peg to US Dollar-a } \\
\text { system of mini devaluations with a PPP rule is introduced. }\end{array}$ \\
\hline April 1975-June 1977 & $\begin{array}{l}\text { Freely falling/De facto crawling band } \\
\text { around US Dollar/Multiple rates }\end{array}$ & \\
\hline July $1977-$ February 281986 & Freely falling/Managed floating & There are multiple exchange rates. \\
\hline February $28,1986-$ September 1986 & Peg to US Dollar/Freely falling & $\begin{array}{l}\text { The Cruzado Plan. The Cruzado replaces the Cruzeiro. } \\
\text { Parallel market premia remains above } 30 \% \text {. }\end{array}$ \\
\hline September 1986-January 1989 & Freely falling/Freely floating & High parallel premium throughout. There are multiple rates. \\
\hline January $16,1989-$ April 1989 & Peg to US Dollar/Freely falling & High parallel premium throughout \\
\hline April 1989-July 1, 1994 & $\begin{array}{l}\text { Freely falling/Freely floating/Multiple } \\
\text { rates }\end{array}$ & $\begin{array}{l}\text { On December } 1989 \text { the parallel market premium rises to } \\
235 \% \text {. December } 1989 \text {-March } 1990 \text { regime is a } \\
\text { "hyperfloat." }\end{array}$ \\
\hline July 1, 1994-May 1995 & $\begin{array}{l}\text { Pre-announced crawling band to US } \\
\text { Dollar/Freely falling/Dual Market }\end{array}$ & $\begin{array}{l}\text { The Real Plan has a narrow band width. The Real replaces } \\
\text { the Cruzado. There is a dual market but parallel premium } \\
\text { during this period is trivial. }\end{array}$ \\
\hline June 1995-January 18, 1999 & $\begin{array}{l}\text { Pre-announced crawling band to US } \\
\text { Dollar/Dual Market }\end{array}$ & \\
\hline February 1 1999-August 1999 & Freely falling/Managed floating & On January 18,1999 the two rates were unified. \\
\hline September 1999-December 2001 & Managed floating & \\
\hline
\end{tabular}


Bulgaria

\begin{tabular}{|l|l|l|}
\hline Date & $\begin{array}{l}\text { Classification } \\
\text { Primary/Secondary/Tertiary }\end{array}$ & Comments \\
\hline May 2, 1990-December 1993 & $\begin{array}{l}\text { Freely falling/Freely floating/Dual } \\
\text { Market }\end{array}$ & There is no price data before this date. \\
\hline January 1994-January 1, 1997 & Freely falling/Managed floating & \\
\hline January 1, 1997-January, 1998 & $\begin{array}{l}\text { Peg to DM/Currency board/Freely } \\
\text { falling }\end{array}$ & \\
\hline January, 1998-January 1, 1999 & Currency board/Peg to DM & \\
\hline January 1, 1999-December, 2001 & Currency board/Peg to Euro & \\
\hline
\end{tabular}

Notes: Reference currencies are US Dollar, DM and Euro.

Burkina Faso

Central Bank of West African States: Benin, Burkina Faso, Cote D'Ivoire, Guinea-Bissau, Mali, Niger, Senegal, and Togo ${ }^{1}$

\begin{tabular}{|l|l|l|}
\hline Date & $\begin{array}{l}\text { Classification } \\
\text { Primary/Secondary/Tertiary }\end{array}$ & Comments \\
\hline June 29, 1901 & Peg to French Franc & $\begin{array}{l}\text { Banque de l'Afrique Occidentale is allowed to issue bank } \\
\text { notes. }\end{array}$ \\
\hline September 9, 1939 & $\begin{array}{l}\text { Exchange controls are introduced in } \\
\text { Franc Zone }\end{array}$ & \\
\hline February 2, 1943-December 26, 1945 & Peg to US Dollar and Pound Sterling & On December 1942 incorporated in the Sterling Area \\
\hline December 26, 1945-May 12, 1962 & Peg to French Franc & Return to Franc Zone. The CFA Franc is introduced. \\
\hline May 12, 1962-September 9, 1971 & Peg to French Franc & Creation of the Central Bank of West African States \\
\hline September 9, 1971-March 21, 1974 & $\begin{array}{l}\text { De facto peg to French Franc/Dual } \\
\text { Market }\end{array}$ & The premium is in low single digits. \\
\hline March 21, 1974-January 1, 1999 & Peg to French Franc & One 100\% devaluation. \\
\hline January 1, 1999-December 2001 & Peg to Euro & \\
\hline
\end{tabular}

${ }^{1}$ Mali joined the currency arrangement at a later date.

Note: Formerly Upper Volta. Reference currencies are the French Franc and the Euro

Burundi

\begin{tabular}{|c|c|c|}
\hline Date & $\begin{array}{l}\text { Classification } \\
\text { Primary/Secondary/Tertiary }\end{array}$ & Comments \\
\hline June 1919-January 21, 1941 & Peg to Belgian Franc & \\
\hline June $7,1940-$ January 21,1941 & Peg to French Franc & \\
\hline January $21,1941-$ October 5,1944 & Peg to Pound Sterling & Entry into Sterling Area \\
\hline October 5, 1944- September 22, 1960 & Peg to Belgian Franc & \\
\hline September 22, 1960-May 19, 1964 & Peg to Belgian Franc/Dual Market & $\begin{array}{l}\text { Rwanda-Burundi Franc replaced Congolese Franc. Parallel } \\
\text { market data not available. }\end{array}$ \\
\hline May 19, 1964-January 26, 1965 & Peg to Belgian Franc/Dual Market & $\begin{array}{l}\text { Burundi Franc replaces Rwanda-Burundi Franc. } \\
\text { In } 1965 \text { the link to the Belgian Franc was broken }\end{array}$ \\
\hline January 26, 1965-April 21, 1970 & De facto peg to US Dollar & $\begin{array}{l}\text { In February 11, } 1965 \text { the multiple rate structure was } \\
\text { terminated. Parallel market data not available. }\end{array}$ \\
\hline April 21, 1970-December 1977 & Peg to US Dollar & \\
\hline January $1978-$ July 1979 & Peg to US Dollar/Freely falling & \\
\hline August 1979-November 23, 1983 & Peg to US Dollar & \\
\hline November 23, 1983-May, 1985 & De facto crawling peg to US Dollar & Officially pegged to the SDR.. \\
\hline May 1985-August 1985 & $\begin{array}{l}\text { De facto crawling band around US } \\
\text { Dollar }\end{array}$ & $\begin{array}{l}\text { Officially pegged to the SDR since November } 23,1983 . \\
\text { Band width is }+/-2 \%\end{array}$ \\
\hline September 1985-April 1, 1992 & $\begin{array}{l}\text { De facto crawling band around US } \\
\text { Dollar }\end{array}$ & Officially pegged to SDR Band width is $+/-5 \%$. \\
\hline April 1 1992-April 1996 & $\begin{array}{l}\text { De facto crawling band around US } \\
\text { Dollar }\end{array}$ & $\begin{array}{l}\text { Band width is }+/-5 \% \text {. Officially pegged to a basket of } \\
\text { undisclosed currencies. }\end{array}$ \\
\hline May 1996-May 1997 & Freely falling/Managed floating & Officially pegged to a basket of undisclosed currencies \\
\hline June 1997-November 18, 1999 & $\begin{array}{l}\text { De facto crawling band around US } \\
\text { Dollar/Parallel market }\end{array}$ & $\begin{array}{l}\text { Officially pegged to a basket of undisclosed currencies. On } \\
\text { July } 1,1999 \text { the official arrangement was reclassified as } \\
\text { managed floating. Premium in the } 10-40 \% \text { range. }\end{array}$ \\
\hline November $18,1999-$ July 1,2000 & $\begin{array}{l}\text { De facto crawling band around US } \\
\text { Dollar/Dual Market }\end{array}$ & $\begin{array}{l}\text { Managed to limit the spread between the official and } \\
\text { parallel rates. }\end{array}$ \\
\hline July $1,2000-$ December 2001 & $\begin{array}{l}\text { De facto crawling band around US } \\
\text { Dollar }\end{array}$ & Markets were unirfied. \\
\hline
\end{tabular}

Notes: Reference currencies are the Belgian Franc, US Dollar, SDR, and South African Rand. 


\section{Cameroon}

Bank of Central African States: Central African Republic, Chad, Gabon, and Republic of Congo

\begin{tabular}{|l|l|l|}
\hline Date & $\begin{array}{l}\text { Classification } \\
\text { Primary/Secondary/Tertiary }\end{array}$ & Comments \\
\hline December 31, 1925 & Peg to French Franc & $\begin{array}{l}\text { Only notes issued by Banque de l'Afrique Occidental are } \\
\text { legal tender. Exchange controls are introduced within Franc } \\
\text { Zone on September 9, } 1939 .\end{array}$ \\
\hline December 26. 1945-January 26,1948 & $\begin{array}{l}\text { Peg to French Franc/ Currency } \\
\text { union/Freely falling }\end{array}$ & Nhe Franc is introduced. \\
\hline January 26, 1948-December 1948 & Freely falling/Dual Market & No parallel market data for this period. \\
\hline January 1949-September 20, 1949 & Dual Market & \\
\hline September 20, 1949-January 17, 1962 & Peg to French Franc & Bank of Central African States is created. \\
\hline January 17, 1962-September 9, 1971 & Peg to French Franc & The premium is in low single digits. \\
\hline September 9, 1971-March 21, 1974 & $\begin{array}{l}\text { De facto peg to French Franc/Dual } \\
\text { Market }\end{array}$ & One 100\% devaluation. \\
\hline March 21, 1974-December 1995 & Peg to French Franc & \\
\hline January 1994-December 1994 & Peg to French Franc/ Freely falling & \\
\hline January 1995-January 1, 1999 & Peg to French Franc & \\
\hline January 1, 1999-December 2001 & Peg to Euro & \\
\hline Not
\end{tabular}

Notes: Reference currencies are the French Franc and the Euro.

Canada

\begin{tabular}{|l|l|l|}
\hline Date & $\begin{array}{l}\text { Classification } \\
\text { Primary/Secondary/Tertiary }\end{array}$ & Comments \\
\hline September 16, 1939-July 5, 1946 & Dual Market & Foreign exchange controls \\
\hline July 5, 1946- October 1, 1950 & Peg to US Dollar & Premium is trivial since 1949. \\
\hline October 1, 1950-May 2, 1962 & $\begin{array}{l}\text { De facto peg to the US Dollar/Dual } \\
\text { Market }\end{array}$ & Band width is $+/-2 \%$. \\
\hline May 2, 1962-May 31, 1970 & $\begin{array}{l}\text { Peg to US Dollar } \\
\text { Dollar }\end{array}$ & \\
\hline May 31, 1970-December 2001 & & \\
\hline
\end{tabular}

Notes: Reference currency is the US Dollar.

Central African Republic

Bank of Central African States: Central African Republic, Chad, Gabon, and Republic of Congo

\begin{tabular}{|l|l|l|}
\hline Date & $\begin{array}{l}\text { Classification } \\
\text { Primary/Secondary/Tertiary }\end{array}$ & Comments \\
\hline June 6, 1925- February 8, 1944 & Peg to French Franc & $\begin{array}{l}\text { Only notes issued by Banque de l'Afrique Occidental are } \\
\text { legal tender. Exchange controls are introduced within } \\
\text { Franc Zone on September 9, 1939. }\end{array}$ \\
\hline February 8, 1944-December 26, 1945 & Peg to US Dollar and Pound Sterling & On March 19, 1941 incorporated in the Sterling Area \\
\hline December 26. 1945-January 17, 1962 & Peg to French Franc & Return to Franc Zone. CFA Franc is introduced. \\
\hline January 17, 1962-September 9, 1971 & Peg to French Franc & Bank of Central African States is Created \\
\hline September 9, 1971-March 21, 1974 & $\begin{array}{l}\text { De facto peg to the French Franc/Dual } \\
\text { Market }\end{array}$ & The premium is in low single digits. \\
\hline March 21, 1974-December 1993 & Peg to French Franc & \\
\hline January 1994-January 1995 & Peg to French Franc/Freely falling & One 100\% devaluation. \\
\hline February 1995-January 1, 1999 & Peg to French Franc & \\
\hline January 1, 1999-December 2001 & Peg to Euro & \\
\hline
\end{tabular}

Notes: Previously part of Ubangi-Shari. Reference currencies are the French Franc and the Euro.

Chad

Bank of Central African States: Central African Republic, Chad, Gabon, and Republic of Congo

\begin{tabular}{|l|l|l|}
\hline Date & $\begin{array}{l}\text { Classification } \\
\text { Primary/Secondary/Tertiary }\end{array}$ & Comments \\
\hline June 6, 1925- February 8, 1944 & Peg to French Franc & $\begin{array}{l}\text { Only notes issued by Banque de l'Afrique Occidental are } \\
\text { legal tender. Exchange controls are introduced within Franc } \\
\text { Zone on September 9, 1939. }\end{array}$ \\
\hline February 8, 1944- December 26, 1945 & Peg to US Dollar and Pound Sterling & On March 19, 1941 incorporated in the Sterling Area. \\
\hline December 26. 1945-January 17, 1962 & Peg to French Franc & Return to Franc Zone. CFA Franc is introduced. \\
\hline January 17, 1962-September 9, 1971 & Peg to French Franc & Bank of Central African States is created. \\
\hline September 9, 1971-March 21, 1974 & $\begin{array}{l}\text { De facto peg to French Franc/Dual } \\
\text { Market }\end{array}$ & The premium is in low single digits. \\
\hline March 21, 1974-December 1993 & Peg to French Franc & \\
\hline January 1994-January 1995 & Peg to French Franc/Freely falling & One 100\% devaluation. \\
\hline February 1995-January 1, 1999 & Peg to French Franc & \\
\hline January 1, 1999_December 2001 & Peg to Euro & \\
\hline
\end{tabular}

Notes: Previously part of Ubangi-Shari. Reference currencies are the French Franc and the Euro. 
Chile

\begin{tabular}{|c|c|c|}
\hline Date & $\begin{array}{l}\text { Classification } \\
\text { Primary/Secondary/Tertiary }\end{array}$ & Comments \\
\hline September 16, 1925- April 20, 1932 & Peg & $\begin{array}{l}\text { Gold standard. Foreign exchange controls are introduced in } \\
\text { on July } 30,1931 \text {. }\end{array}$ \\
\hline April 20, 1932-1937 & Dual Market & $\begin{array}{l}\text { Pound Sterling is reference currency. Suspension of gold } \\
\text { standard. }\end{array}$ \\
\hline 1937-February, 1946 & Managed floating/Multiple rates & US Dollar is the reference currency \\
\hline March 1946-May 1947 & $\begin{array}{l}\text { Freely falling/Managed } \\
\text { floating/Multiple rates }\end{array}$ & US Dollar is the reference currency \\
\hline June 1947-October 1952 & Managed floating/Multiple rates & \\
\hline November 1952-April 16, 1956 & $\begin{array}{l}\text { Freely falling/Managed } \\
\text { floating/Multiple rates }\end{array}$ & US Dollar is the reference currency \\
\hline April 16, 1956-August 1957 & $\begin{array}{l}\text { Freely falling/Managed floating/Dual } \\
\text { Market }\end{array}$ & \\
\hline September 1957-June 1958 & Managed floating/Dual Market & \\
\hline July 1958-January 1,1960 & $\begin{array}{l}\text { Freely falling/Managed floating/Dual } \\
\text { Market }\end{array}$ & \\
\hline January 1, 1960-January 15,1962 & Peg to US Dollar & The Escudo replaces the peso. \\
\hline January $15,1962-$ April 1964 & $\begin{array}{l}\text { Freely falling/Managed } \\
\text { floating/Multiple rates }\end{array}$ & \\
\hline January $15,1962-$ June 1971 & Managed floating/Multiple rates & \\
\hline July 1971-June 29, 1976 & Freely falling/Multiple exchange rates & $\begin{array}{l}\text { On September 29, } 1975 \text { the Peso replaced the Escudo. } \\
\text { October } 1973 \text { classifies as a hyperfloat. }\end{array}$ \\
\hline June 29, 1976-January 1978 & $\begin{array}{l}\text { Freely falling/Crawling peg to US } \\
\text { Dollar }\end{array}$ & \\
\hline February 1978-June 1978 & $\begin{array}{l}\text { Pre announced crawling peg to US } \\
\text { Dollar/Freely falling }\end{array}$ & The Tablita Plan \\
\hline July 1978-June 30, 1979 & $\begin{array}{l}\text { Pre announced crawling peg to US } \\
\text { Dollar }\end{array}$ & The Tablita Plan \\
\hline June 30, 1979-June 15, 1982 & Peg to US Dollar & The second phase of the Tablita Plan \\
\hline June 15, 1982-December, 1982 & $\begin{array}{l}\text { Freely falling/Managed floating/Dual } \\
\text { Market }\end{array}$ & \\
\hline December 1982-December 8, 1984 & Managed floating/Dual Market & $\begin{array}{l}\text { Parallel market premium reaches } 102 \% \text { in early } 1983 \text {. On } \\
\text { March } 1983 \text { the intentions to follow a PPP rule was } \\
\text { announced. }\end{array}$ \\
\hline December 8, 1984-January 1988 & Managed floating/Dual Market & $\begin{array}{l}\text { PPP rule. The official rate is kept within a }+/-2 \% \text { crawling } \\
\text { band to US Dollar the June } 1985 \text {. Yet, while the official } \\
\text { rate remains within the band, parallel market premia remain } \\
\text { in the } 20-40 \% \text { range and scores as managed floating. }\end{array}$ \\
\hline January 1988-January 1, 1989 & $\begin{array}{l}\text { De facto crawling band around US } \\
\text { Dollar/Dual Market }\end{array}$ & $\begin{array}{l}\text { PPP rule. Band width is }+/-5 \% \text {. Official pre-announced } \\
\text { crawling band to US Dollar. Band width is }+/-3 \% \text {. While } \\
\text { the official rate remains within the band narrower band, } \\
\text { parallel market premia remain in double digits. }\end{array}$ \\
\hline June 1, 1989-January 22, 1992 & $\begin{array}{l}\text { Pre announced crawling band around } \\
\text { US Dollar/Dual Market }\end{array}$ & PPP rule. Band width is $+/-5 \%$. \\
\hline January 22, 1992- January 20, 1997 & $\begin{array}{l}\text { De facto crawling band around US } \\
\text { Dollar/Dual Market }\end{array}$ & $\begin{array}{l}\text { PPP rule. Band is }+/-5 \% \text {. Official pre-announced crawling } \\
\text { band to US Dollar. Band width is }+/-10 \% \text {. Parallel } \\
\text { premium declines to below } 15 \% \text { and into single digits. }\end{array}$ \\
\hline January 20, 1997-June 25, 1998 & $\begin{array}{l}\text { De facto crawling band to US } \\
\text { Dollar/Dual Market }\end{array}$ & $\begin{array}{l}\text { Official pre-announced crawling band to US Dollar. Band } \\
\text { width is }+/-12.5 \% \text {, de facto band is }+/-5 \% \text { for the official } \\
\text { rate and }+/-2 \% \text { for the parallel rate. }\end{array}$ \\
\hline June 25, 1998-September 16, 1998 & $\begin{array}{l}\text { Pre-announced crawling band to US } \\
\text { Dollar/Dual Market }\end{array}$ & Band width is, $+/-2.75 \%$. \\
\hline $\begin{array}{l}\text { September 16, 1998-December 22, } \\
1998\end{array}$ & $\begin{array}{l}\text { Pre announced crawling band to US } \\
\text { Dollar/Dual Market }\end{array}$ & Band width is $+/-3.5 \%$. \\
\hline $\begin{array}{l}\text { December 22, 1998-September 2, } \\
1999\end{array}$ & $\begin{array}{l}\text { Pre announced crawling band to US } \\
\text { Dollar/Dual Market }\end{array}$ & Band width is $+/-8 \%$. \\
\hline September 2, 1999-December 2001 & Managed floating & Rates are unified. \\
\hline
\end{tabular}

Notes: Reference currency is the US Dollar. 
China

\begin{tabular}{|c|c|c|}
\hline Date & $\begin{array}{l}\text { Classification } \\
\text { Primary/Secondary/Tertiary }\end{array}$ & Comments \\
\hline November 3, 1935-March 14, 1938 & Peg to Pound Sterling & $\begin{array}{l}\text { Abandoned silver standard. Monetary breakup. Canton } \\
\text { Dollar and Northern China Dollar are created. Canton Dollar } \\
\text { is pegged to Chinese Dollar. Northern China Dollar is not } \\
\text { pegged to any currency until March 1, } 1938 \text { in which it pegs } \\
\text { to the Yen. }\end{array}$ \\
\hline March 14, 1938-1939 & Capital controls & \\
\hline 1939- August 19, 1948 & Freely falling/Dual Market & Most transactions take place at free market rate. \\
\hline August 19, 1948-December 1951 & $\begin{array}{l}\text { Freely falling/Freely floating/Dual } \\
\text { Market }\end{array}$ & $\begin{array}{l}\text { Gold Yuan is introduced to replace China Dollar on } \\
\text { September } 21,1949 .\end{array}$ \\
\hline January 1952- June 1969 & Managed floating/Dual Market & $\begin{array}{l}\text { Jen Min Piao (Yuan) is introduced to replace Gold Yuan. } \\
\text { Parallel market premium climbs to } 347 \% \text { on July } 1958 \text { and } \\
763 \% \text { on June } 1962 \text {. }\end{array}$ \\
\hline June 1969- December 1973 & $\begin{array}{l}\text { Managed floating/Dual } \\
\text { Market/Multiple rates }\end{array}$ & Renmimbi is introduced. \\
\hline January 1974-February 1981 & $\begin{array}{l}\text { De facto crawling band around US } \\
\text { Dollar/Multiple rates }\end{array}$ & Band width is $+/-2 \%$. \\
\hline March 1981-July 1992 & Managed floating/Multiple rates & \\
\hline August 1992-January 1, 1994 & $\begin{array}{l}\text { De facto crawling band around US } \\
\text { Dollar/Multiple rates }\end{array}$ & $\begin{array}{l}\text { Band width is }+/-2 \% \text {. Premium peaks at } 124 \% \text { on June } \\
1991 \text {. }\end{array}$ \\
\hline January 1, 1994-December 2001 & De facto peg to US Dollar & $\begin{array}{l}\text { Unification of markets. There is a parallel market where the } \\
\text { premium is in single digits. }\end{array}$ \\
\hline
\end{tabular}

Notes: Reference currency is the US Dollar.

Colombia

\begin{tabular}{|c|c|c|}
\hline Date & $\begin{array}{l}\text { Classification } \\
\text { Primary/Secondary/Tertiary }\end{array}$ & Comments \\
\hline January 1935-April 1944 & Managed float/Dual Market & Free market rate applied to most transactions \\
\hline April 1944-September 1946 & Peg to US Dollar & \\
\hline October 1946-June 1947 & Peg to US Dollar/Freely falling & \\
\hline July 1947-January 1948 & Peg to US Dollar & \\
\hline January $1948-$ February 1952 & De facto peg to US Dollar/Multiple rates & Parallel market premium reaches $183 \%$ on March 1957. \\
\hline March 1953-September 1962 & $\begin{array}{l}\text { De facto crawling band around US } \\
\text { Dollar/Multiple rates }\end{array}$ & $\begin{array}{l}\text { Band width is }+/-5 \% \text {. PPP rule. Pre announced crawling peg } \\
\text { to US Dollar. Premium usually in single digits. }\end{array}$ \\
\hline October 1962-December 1963 & $\begin{array}{l}\text { Freely falling/De facto crawling band } \\
\text { around US Dollar/Multiple rates }\end{array}$ & $\begin{array}{l}\text { Band width is }+/-5 \% \text {. PPP rule. Pre announced crawling peg } \\
\text { to US Dollar. Premium usually in single digits. }\end{array}$ \\
\hline January 1964-April 1974 & $\begin{array}{l}\text { De facto crawling band around US } \\
\text { Dollar/Multiple rates }\end{array}$ & $\begin{array}{l}\text { Band width is }+/-5 \% \text {. PPP rule. Pre announced crawling peg } \\
\text { to US Dollar. Premium usually in single digits. }\end{array}$ \\
\hline April 1974-September 1983 & $\begin{array}{l}\text { De facto band around US } \\
\text { Dollar/Multiple rates }\end{array}$ & $\begin{array}{l}\text { Band width is }+/-2 \% \text {. On May } 1984 \text { the premium rises to } \\
36 \% \text {. }\end{array}$ \\
\hline October 1983-November 1984 & Managed floating/Multiple rates & More accurately, the rate of crawl had been accelerated. \\
\hline December 1984-January 24, 1994 & $\begin{array}{l}\text { De facto band around US } \\
\text { Dollar/Multiple rates }\end{array}$ & Band width is $+/-5 \%$. \\
\hline January 24, 1994- June 28, 1999 & $\begin{array}{l}\text { De facto crawling band around US } \\
\text { Dollar }\end{array}$ & $\begin{array}{l}\text { Band width is }+/-5 \% \text {. Official pre announced crawling band } \\
\text { around US Dollar, width is }+/-7.5 \%\end{array}$ \\
\hline June 28, 1999-September 25, 1999 & $\begin{array}{l}\text { De facto crawling band around US } \\
\text { Dollar }\end{array}$ & $\begin{array}{l}\text { Band width is }+/-5 \% \text {. There is an official pre announced } \\
\text { crawling band around US Dollar, which is }+/-10 \% \text {. Parallel } \\
\text { market premium remains below } 20 \% \text {. }\end{array}$ \\
\hline September 25, 1999-December 2001 & Managed floating & \\
\hline
\end{tabular}

Notes: Reference currency is the US dollar. 
Congo, Democratic Republic of

\begin{tabular}{|c|c|c|}
\hline Date & $\begin{array}{l}\text { Classification } \\
\text { Primary/Secondary/Tertiary }\end{array}$ & Comments \\
\hline June 1919-June 7, 1940 & Peg to Belgian Franc & \\
\hline June 7, 1940-January 21, 1941 & Peg to French Franc & \\
\hline January $21,1941-$ October 5,1944 & Peg to Pound Sterling & Entry into Sterling Area \\
\hline October $5,1944-$ November 6,1962 & Parallel market & $\begin{array}{l}\text { The official rate is pegged to the Belgian Franc. No parallel } \\
\text { market data available. }\end{array}$ \\
\hline November 6, 1962-October 1963 & Managed floating/Dual Market & \\
\hline November 1963 -November 9, 1963 & $\begin{array}{l}\text { Freely falling/Managed floating/Dual } \\
\text { Market }\end{array}$ & The official rate is pegged to the Belgian Franc. \\
\hline November 9, 1963-May 1964 & $\begin{array}{l}\text { Freely falling/Managed } \\
\text { floating/Parallel market }\end{array}$ & The official rate is pegged to the Belgian Franc. \\
\hline June 1965-July 23, 1967 & Managed floating/Parallel Market & The official rate is pegged to the Belgian Franc. \\
\hline July $23,1967-$ August 24,1971 & Managed floating/Parallel market & $\begin{array}{l}\text { Zaire replaces Congolese Franc. The official rate is pegged } \\
\text { to the Belgian Franc. }\end{array}$ \\
\hline August 24, 1971-December 1974 & $\begin{array}{l}\text { De facto Crawling band around US } \\
\text { Dollar/Parallel market }\end{array}$ & $\begin{array}{l}\text { The official rate is pegged to the US Dollar. Band width is } \\
+/-5 \% \text {. }\end{array}$ \\
\hline January 1975-March 12, 1976 & $\begin{array}{l}\text { Freely falling/Managed } \\
\text { floating/Parallel market }\end{array}$ & The official rate is pegged to the US Dollar. \\
\hline March 12, 1976-September 12, 1983 & Freely falling/Freely floating & Official Peg to SDR \\
\hline September 12, 1983-November 1997 & $\begin{array}{l}\text { Freely falling/Dual Markets/Managed } \\
\text { floating }\end{array}$ & $\begin{array}{l}\text { There were short-lived efforts to unify markets on March 1, } \\
1984 \text { and again on August 19, } 1991 . \\
\text { October 1991-September 1992 and November 1993- } \\
\text { September 1994 regimes are "hyperfloats". }\end{array}$ \\
\hline December 1997-December 2001 & & $\begin{array}{l}\text { No inflation data post February } 1998 \text {. No exchange rate } \\
\text { data for 2001. Effective May } 2001 \text { the exchange rates were } \\
\text { unified. }\end{array}$ \\
\hline
\end{tabular}

Notes: Formerly Belgian Congo and Zaire. Reference currencies are the Belgian Franc, US Dollar. SDR, and South African Rand.

Congo. Republic of

Bank of Central African States: Central African Republic, Chad, Gabon, and Republic of Congo

\begin{tabular}{|l|l|l|}
\hline Date & $\begin{array}{l}\text { Classification } \\
\text { Primary/Secondary/Tertiary }\end{array}$ & Comments \\
\hline June 6, 1925- February 8, 1944 & Peg to French Franc & $\begin{array}{l}\text { Only notes issued by Banque de 1'Afrique Occidental are } \\
\text { legal tender. Exchange controls are introduced in franc } \\
\text { Zone on September 9, 1939. }\end{array}$ \\
\hline February 8, 1944- December 26, 1945 & Peg to US Dollar and Pound Sterling & On March 19, 1941 incorporated in the Sterling Area \\
\hline December 26. 1945-December 1947 & Peg to French Franc & Return to Franc Zone. CFA Franc is introduced. \\
\hline January 1948-December 1949 & Peg to French Franc/Freely falling & \\
\hline January 1950-January 17, 1962 & Peg to French Franc & Bank of Central African States is created \\
\hline January 17, 1962-September 9, 1971 & Peg to French Franc/Currency union & The premium is in low single digits. \\
\hline September 9, 1971-March 21, 1974 & Market/De facto peg to French Franc & \\
\hline March 21, 1974-December 1993 & Peg to French Franc/Currency union & \\
\hline January 1994-January 1995 & $\begin{array}{l}\text { Peg to French Franc/Currency union/ } \\
\text { Freely falling }\end{array}$ & One 100\% devaluation. \\
\hline February 1995-January 1, 1999 & Peg to French Franc/Currency union & \\
\hline January 1, 1999-December 2001 & Peg to Euro & \\
\hline
\end{tabular}

Notes: Previously Middle Congo. Reference currencies are the French Franc and the Euro. 
Costa Rica

\begin{tabular}{|c|c|c|}
\hline Date & $\begin{array}{l}\text { Classification } \\
\text { Primary/Secondary/Tertiary }\end{array}$ & Comments \\
\hline October 10, 1922-October 13, 1948 & Peg to US Dollar & \\
\hline October 13, 1948-February 1963 & $\begin{array}{l}\text { De facto peg to US Dollar/Multiple } \\
\text { rates }\end{array}$ & $\begin{array}{l}\text { Official peg to the US Dollar. On June } 1950 \text { the parallel } \\
\text { market premium peaks at } 64 \% \text {. }\end{array}$ \\
\hline March 1963-December 24, 1969 & $\begin{array}{l}\text { De facto crawling band around US } \\
\text { Dollar/Multiple rates }\end{array}$ & Band width $+/-2 \%$. Official Peg to the US Dollar \\
\hline December 24, 1969- June 19, 1971 & Peg to US Dollar & \\
\hline June 19, 1971- April 25, 1974 & $\begin{array}{l}\text { De facto crawling band around US } \\
\text { Dollar/Dual Market }\end{array}$ & $\begin{array}{l}\text { Band width }+/-5 \% \text {. Official Peg to the US Dollar. Parallel } \\
\text { market premium consistently above } 50 \% \text {. }\end{array}$ \\
\hline April 25, 1974-September 26, 1980 & Peg to US Dollar & \\
\hline September 26, 1980-December 1980 & Managed floating & \\
\hline January 1981-March, 1981 & Freely falling/Managed floating & \\
\hline March 9, 1981-November 11,1983 & $\begin{array}{l}\text { Freely falling/Managed } \\
\text { floating/Multiple rates }\end{array}$ & $\begin{array}{l}\text { Periodic attempts to fix the official rate are interspersed } \\
\text { with frequent devaluations. }\end{array}$ \\
\hline November 11, 1983- December 1990 & $\begin{array}{l}\text { De facto crawling band around US } \\
\text { Dollar/Dual Market }\end{array}$ & $\begin{array}{l}\text { De facto band width is }+/-5 \% \text {., much narrower band if } \\
\text { official rate is used. }\end{array}$ \\
\hline January 1991- December 2001 & De facto crawling band around US Dollar & $\begin{array}{l}\text { De facto band width is }+/-2 \% \text {. Parallel market premia is } \\
\text { in low single digits. De facto crawling peg to US Dollar } \\
\text { since } 1995 \text { if official rate is used. }\end{array}$ \\
\hline
\end{tabular}

Notes: Reference currency is the US Dollar.

Cote D'Ivoire

Central Bank of West African States: Benin, Burkina Faso, Cote D'Ivoire, Guinea-Bissau, Mali, Niger, Senegal, and Togo ${ }^{1}$

\begin{tabular}{|l|l|l|}
\hline Date & $\begin{array}{l}\text { Classification } \\
\text { Primary/Secondary/Tertiary }\end{array}$ & Comments \\
\hline June 29, 1901- February 2, 1943 & Peg to French Franc & $\begin{array}{l}\text { Banque de 1'Afrique Occidentale is allowed to issue bank } \\
\text { notes. Exchange controls are introduced in Franc Zone on } \\
\text { September 9, 1939. }\end{array}$ \\
\hline February 2, 1943- December 26, 1945 & Peg to US Dollar and Pound Sterling \\
December 26. 1945-January 26, & Peg to French Franc/Currency union & Return to Franc Zone. The CFA Franc is introduced. \\
\hline January 26, 1948-September 20,1949 & Dual Market & $\begin{array}{l}\text { Parallel market data is not available for this period. Linked } \\
\text { to French Franc. }\end{array}$ \\
\hline September 20, 1949-May 12, 1962 & Peg to French Franc & Creation of the Central Bank of West African States \\
\hline May 12, 1962-September 9, 1971 & Peg to French Franc & The premium is in low single digits. \\
\hline September 9, 1971-March 21, 1974 & $\begin{array}{l}\text { De facto peg to French Franc/Dual } \\
\text { Market }\end{array}$ & One 100\% devaluation. \\
\hline March 21, 1974-January 1, 1999 & Peg to French Franc & \\
\hline January 1, 1999-December 2001 & Peg to Euro & \\
\hline
\end{tabular}

${ }^{1}$ Mali joined the currency arrangement on June 1, 1984. Reference currencies are the French Franc and the Euro.

Croatia

\begin{tabular}{|l|l|l|}
\hline Date & $\begin{array}{l}\text { Classification } \\
\text { Primary/Secondary/Tertiary }\end{array}$ & Comments \\
\hline October 22, 1993-September 1994 & $\begin{array}{l}\text { Freely falling/Freely floating/Dual } \\
\text { Market }\end{array}$ & There is no price data before this date. \\
\hline October 1994-January 1, 1999 & De facto band around DM & Band width is $+/-2 \%$. \\
\hline January 1, 1999-December 2001 & De facto band around Euro & Band width is $+/-2 \%$. \\
\hline
\end{tabular}

Notes: Reference currencies are the US Dollar, the DM and the Euro.

Cyprus

\begin{tabular}{|l|l|l|}
\hline Date & $\begin{array}{l}\text { Classification } \\
\text { Primary/Secondary/Tertiary }\end{array}$ & Comments \\
\hline September 5, 1917-June 29,1972 & Peg to Pound Sterling & Cyprus Pound is introduced. \\
\hline June 29, 1972-July 9, 1973 & Peg & Gold \\
\hline July 9, 1973-March 1992 & De facto crawling band around DM & Band width is $+/-2 \%$. \\
\hline April 1992-January 1, 1999 & De facto peg to DM & Officially there is a $+/-2.25 \%$ band. \\
\hline January 1, 1999-December 2001 & De facto peg to Euro & $\begin{array}{l}\text { In January 2001, it was announced that the band width } \\
\text { would be widened to }+/-15 \% \text { to be become effective in } \\
\text { August 2001. }\end{array}$ \\
\hline
\end{tabular}

Notes: Reference currencies are the US Dollar, the Pound Sterling, DM and the Euro. 
Czech Republic

\begin{tabular}{|l|l|}
\hline Date & $\begin{array}{l}\text { Classification } \\
\text { Primary/Secondary/Tertiary }\end{array}$ \\
\hline September 1990-February 28, 1996 & De facto crawling band around DM \\
\hline February 28, 1996-May 27, 1997 & De facto crawling band around DM \\
\hline May 27, 1997-December 2001 & Managed floating \\
\hline
\end{tabular}

Notes: Reference currencies are the US Dollar, the DM and the Euro.

Denmark

\begin{tabular}{|c|c|c|}
\hline Date & $\begin{array}{l}\text { Classification } \\
\text { Primary/Secondary/Tertiary }\end{array}$ & Comments \\
\hline December 22, 1926- September 29, 1931 & Peg & Gold Standard \\
\hline September 29, 1931-November 1936 & Peg to Pound Sterling & $\begin{array}{l}\text { Suspension of convertibility. Joined the Sterling Area. On } \\
\text { November } 18 \text {, foreign exchange controls are introduced. }\end{array}$ \\
\hline November 1936-April 1940 & Peg to Pound Sterling & Tightening of controls \\
\hline April 1940-August 1945 & Peg to Reichsmark & \\
\hline August $1945-$ September 16,1950 & $\begin{array}{l}\text { Peg to US Dollar and Pound } \\
\text { Sterling/Parallel Markets }\end{array}$ & $\begin{array}{l}\text { Parallel market premia peaks in the fall of } 1948 \text { at around } \\
110 \% \text {. }\end{array}$ \\
\hline September $16,1950-$ October 17,1951 & $\begin{array}{l}\text { De facto band around US Dollar/Dual } \\
\text { Market }\end{array}$ & $\begin{array}{l}\text { Band width is }+/-5 \% \text {. Parallel market premium oscillates in } \\
\text { the } 20-60 \% \text { range. }\end{array}$ \\
\hline October 17, 1951-August 23, 1971 & Peg to DM & \\
\hline August 23, 1971-December 1978 & De facto moving band around DM & Band width is $+/-2 \%$. \\
\hline December 1978-January 1, 1999 & De Facto moving peg to DM & \\
\hline January 1, 1999-December 2001 & De facto peg to Euro & Participant of ERM II. There is an official $+/-2.25 \%$ band. \\
\hline
\end{tabular}

Notes: Specifics on the common margins (snake) agreement, EMS, etc. are available from the detailed chronologies. Reference currencies are the US Dollar, the DM and the Euro.

Dominica

East Caribbean Central Bank States are: Anguilla, Antigua and Barbuda, Dominica, Grenada, Montserrat, Saint Kitts and Nevis, Saint Lucia, Saint Vincent and the Grenadines

\begin{tabular}{|l|l|l|}
\hline Date & $\begin{array}{l}\text { Classification: } \\
\text { Primary/Secondary/Tertiary }\end{array}$ & Comments \\
\hline 1935-October 6, 1965 & Peg to Pound Sterling & $\begin{array}{l}\text { British West Indies Dollar is introduced. It is issued by the } \\
\text { East Caribbean Monetary Authority. }\end{array}$ \\
\hline October 6, 1965-July 7, 1976 & Peg to Pound Sterling & East Caribbean Dollar replaces British West Indies Dollar. \\
\hline July 7, 1976-December 2001 & Peg to US Dollar & $\begin{array}{l}\text { ON October 1, 1983 the East Caribbean Central Bank } \\
\text { replaces the East Caribbean Monetary Authority. }\end{array}$ \\
\hline
\end{tabular}

Notes: Reference currency is US Dollar.

Dominican Republic

\begin{tabular}{|c|c|c|}
\hline Date & $\begin{array}{l}\text { Classification } \\
\text { Primary/Secondary/Tertiary }\end{array}$ & Comments \\
\hline June 21, 1905-February 1, 1948 & $\begin{array}{l}\text { Exchange rate arrangement with no } \\
\text { separate legal tender }\end{array}$ & $\begin{array}{l}\text { US Dollar is legal tender. On October } 1947 \text { Peso bank } \\
\text { notes began to be issued. }\end{array}$ \\
\hline February 1, 1948-September 1966 & Managed floating/Parallel Market & Official rate is pegged to US Dollar \\
\hline October 1966-September 1978 & $\begin{array}{l}\text { De facto crawling band around US } \\
\text { Dollar/Parallel Market }\end{array}$ & Band width $+/-2 \%$. Official rate is pegged to US Dollar. \\
\hline October 1978-August 24, 1982 & $\begin{array}{l}\text { De facto crawling band around US } \\
\text { Dollar/Parallel Market }\end{array}$ & Official rate is pegged to US Dollar. \\
\hline August 24, 1982- January 231985 & Managed floating/Dual Market & $\begin{array}{l}\text { Band width }+/-5 \% \text {. Official rate is pegged to US Dollar. } \\
\text { Parallel market premium oscillates in the } 50-90 \% \text { range. } \\
\text { Parallel market premium climbs to } 213 \% \text { prior to the } \\
\text { devaluation on January } 1985\end{array}$ \\
\hline January 23 1985-November 1985 & Freely falling/Managed floating & \\
\hline December 1985-September 4, 1986 & $\begin{array}{l}\text { De facto crawling band around US } \\
\text { Dollar }\end{array}$ & Band width $+/-5 \%$. \\
\hline September 4, 1986-June 1987 & $\begin{array}{l}\text { De facto crawling band around US } \\
\text { Dollar/Dual Market }\end{array}$ & Band width $+/-5 \%$. \\
\hline July $1987-$ November 12,1987 & $\begin{array}{l}\text { Freely falling/ De facto crawling band } \\
\text { around US Dollar/Dual Market }\end{array}$ & \\
\hline November $12,1987-$ February 11,1988 & Freely falling/Managed floating & \\
\hline February 11, 1988-August, 1991 & $\begin{array}{l}\text { Freely falling/Managed floating/Dual } \\
\text { Market }\end{array}$ & There was a temporary unification in 1991. \\
\hline September, 1991-October 1992 & Managed floating/Dual Market & Parallel market premium oscillates and is declining. \\
\hline November 1992-December 2001 & $\begin{array}{l}\text { De facto crawling band around US } \\
\text { Dollar/Dual Market }\end{array}$ & $\begin{array}{l}\text { Band width is }+/-2 \% \text {. Parallel market data ends December } \\
1998 \text { - cannot verify } 1999 \text { onwards. Premium is in single } \\
\text { digits during this period. }\end{array}$ \\
\hline
\end{tabular}

Notes: Reference currency is the US Dollar.

\section{Comments}

Band width is $+/-2 \%$. Officially tied to a currency basket and then changed to the ECU.

Band width is $+/ 5-\%$. Official pre-announced crawling band around DM. Official band width is $+/-7.5 \%$. replaces the East Caribbean Monetary Authority.

Comments

US Dollar is legal tender. On October 1947 Peso bank notes began to be issued.

Official rate is pegged to US Dollar

lar/Parallel Market

Dollar/Parallel Market

Managed floating/Dual Marke

Parallel market premium climbs to $213 \%$ prior to the on January 1985

De facto crawling band around US

Dollar

Freely falling/ De facto crawling band around US Dollar/Dual Market Market

Managed floating/Dual Market

De facto crawling band around US

1998 - cannot verify 1999 digits during this period.
dis. 
Ecuador

\begin{tabular}{|c|c|c|}
\hline Date & $\begin{array}{l}\text { Classification } \\
\text { Primary/Secondary/Tertiary }\end{array}$ & Comments \\
\hline March 4, 1927-February 9, 1932 & Peg & Gold Standard \\
\hline April 30, 1932-December 19, 1935 & Dual Market & Capital controls introduced and lifted on December 1935 \\
\hline July $31,1936-$ July 31,1937 & Controls re-introduced & \\
\hline July $31,1937-$ June 4,1940 & Dual Market & \\
\hline June 4, 1940 & Foreign exchange controls reintroduced & \\
\hline April 28, 1942-June 6. 1947 & Peg to US Dollar & \\
\hline June $6,1947-$ June 1950 & $\begin{array}{l}\text { Managed floating/Multiple rates/Dual } \\
\text { Market }\end{array}$ & An official rate is pegged to the US Dollar. \\
\hline July 1950-June 1957 & $\begin{array}{l}\text { De facto peg to US Dollar/ Multiple } \\
\text { rates/ Dual Market }\end{array}$ & \\
\hline July $1957-$ August 17,1970 & $\begin{array}{l}\text { De facto crawling band around US } \\
\text { Dollar/Multiple rates/Dual Market }\end{array}$ & Band width is $+/-2 \%$. \\
\hline August 17, 1970-November 22, 1971 & Peg to US Dollar & \\
\hline November 22, 1971-February 26, 1973 & $\begin{array}{l}\text { Dual Market/ De facto crawling band } \\
\text { around US Dollar }\end{array}$ & Band width is $+/-2 \%$ \\
\hline February 26, 1973- March 3, 1982 & Peg to US Dollar & $\begin{array}{l}\text { The parallel rate behaves like a crawling band. Band width } \\
\text { is }+/-2 \% \text {. }\end{array}$ \\
\hline March 3, 1982-April, 1984 & $\begin{array}{l}\text { Freely falling/Managed floating/Dual } \\
\text { Market }\end{array}$ & \\
\hline May 1984-March 1987 & $\begin{array}{l}\text { Managed floating/Dual } \\
\text { Market/Multiple rates }\end{array}$ & There was a short-lived unification on November 12, 1985. \\
\hline April, 1987-September, 1993 & Freely falling/ Managed floating & Parallel market premium hits $150 \%$ in 1988 . \\
\hline October 1993-March 3, 1997 & $\begin{array}{l}\text { De facto crawling band around US } \\
\text { Dollar/Dual Market }\end{array}$ & $\begin{array}{l}\text { Band width is }+/-5 \% \text {. Parallel market premium declines } \\
\text { into single digits during this period. }\end{array}$ \\
\hline March 3, 1997-September, 1997 & $\begin{array}{l}\text { De facto crawling band around US } \\
\text { Dollar/Dual Market }\end{array}$ & $\begin{array}{l}\text { Pre-announced crawling band around US Dollar, official } \\
\text { band is }+/-5 \% \text {, the de facto band is }+/-2 \% \text {. }\end{array}$ \\
\hline October 1997- February 12, 1999 & $\begin{array}{l}\text { Freely falling/Pre-announced crawling } \\
\text { band around US Dollar. }\end{array}$ & $\begin{array}{l}\text { The band is widened to }+/-10 \% \text { on March } 25,1998 \text { and } \\
+/-15 \% \text { on September } 14,1998 \text {. }\end{array}$ \\
\hline February 12, 1999-March 13, 2000 & Freely falling/Freely floating & Markets are unified. \\
\hline March 13, 2000-April, 2001 & $\begin{array}{l}\text { Exchange rate arrangement with no } \\
\text { separate legal tender/Freely falling }\end{array}$ & US Dollar \\
\hline May 2001-December, 2001 & $\begin{array}{l}\text { Exchange rate arrangement with no } \\
\text { separate legal tender }\end{array}$ & US Dollar \\
\hline
\end{tabular}

Notes: Reference currency is the US Dollar.

Egypt

\section{Date}

September 29, 1931-1950

1950-May 7, 1962

May 7, 1962-July 25, 1971

July 25, 1971-October 8, 1991

October 8, 1991-December 2001

Notes: Reference currency is the US Dollar.

\section{EI Salvador}

\begin{tabular}{|l|l|}
\hline Date & $\begin{array}{l}\text { Classification } \\
\text { Primary/Secondary/Tertiary }\end{array}$ \\
\hline April 1934-April 1961 & Peg to US Dollar \\
\hline May 1961-August 9, 1982 & $\begin{array}{l}\text { De facto crawling band around US } \\
\text { Dollar/Parallel Market }\end{array}$ \\
\hline August 9, 1982-June 1,1990 & Managed floating/Dual Market \\
\hline March 19, 1990-June 1,1990 & $\begin{array}{l}\text { De facto crawling band around US } \\
\text { Dollar/Multiple rates }\end{array}$ \\
\hline June 1, 1990-January 1,2001 & De facto peg to US Dollar \\
\hline January 1, 2001-December 2001 & Peg to US Dollar \\
\hline
\end{tabular}

Notes: Reference currency is the US Dollar.

\section{Classification}

Primary/Secondary/Tertiary

Peg to Pound Sterling

Managed floating/Multiple rates

De facto crawling band around US

Dollar/Multiple rates

De facto crawling band around US

Dollar/Multiple rates

De facto peg to US Dollar/Multiple rates

\section{Comments}

Suspension of Gold Standard, remained in Sterling Area until July 14, 1947 but continued to be linked to the pound.

Links to US Dollar

Band width is $+/-5 \%$. Official rate is pegged to US Dollar and periodically adjusted. Parallel market premium remains consistently above $150 \%$.

Band width is $+/-5 \%$.

Parallel market premia is in single digits through December 1998, when the data ends.

\section{Comments}

Parallel market becomes important in the early 1960s when Foreign exchange controls are reinstated.

Band width is $+/-2 \%$. Official rate is pegged to the US

Dollar.

Third illegal market exists. Premium peaks at 472 percent prior to the January 1986 devaluation.

Band width is $+/-2 \%$.

Parallel market premium is in the 10-20 percent range through most of this period.

En route to full Dollarization. 
Equatorial Guinea

\begin{tabular}{|l|l|l|}
\hline Date & $\begin{array}{l}\text { Classification } \\
\text { Primary/Secondary/Tertiary }\end{array}$ & Comments \\
\hline 1885-October 12, 1969 & $\begin{array}{l}\text { Exchange rate arrangement with no } \\
\text { separate legal tender }\end{array}$ & Spanish Peseta \\
\hline October 12, 1969-December 1973 & Peg to Spanish Peseta & Spanish Peseta is replaced by Peseta Guineana \\
\hline January 1974-April 19, 1979 & Peg to Spanish Peseta/Dual Market & \\
\hline April 19, 1979-August 6, 1979 & Peg to SDR/Dual Market & $\begin{array}{l}\text { Band width is +/-2\%. For official rate no parallel market } \\
\text { data is available. }\end{array}$ \\
\hline August 6, 1979- August 27, 1984 & $\begin{array}{l}\text { Crawling band around French } \\
\text { Franc/Dual Market }\end{array}$ & Joined Central African Monetary Union. One devaluation. \\
\hline August 27, 1984-December 2001 & Peg to French Franc & One 100\% devaluation. \\
\hline January 1994-December 1994 & Peg to French Franc/Freely falling & \\
\hline January 1995-January 1, 1999 & Peg to French Franc & \\
\hline January 1, 1999-December 2001 & Peg to Euro & \\
\hline
\end{tabular}

Notes: Reference currencies are the Spanish Peseta, the SDR, and the French Franc.

\section{Estonia}

\begin{tabular}{|l|l|l|}
\hline Date & $\begin{array}{l}\text { Classification } \\
\text { Primary/Secondary/Tertiary }\end{array}$ & Comments \\
\hline January 1991-June 20, 1992 & Freely falling/Managed floating & There is no price data before this date. \\
\hline June 20, 1992-December 1994 & Peg to DM/Currency board/Freely falling & \\
\hline January 1991-January 1, 1999 & Peg to DM/Currency board & \\
\hline January 1, 1999-December 2001 & Peg to Euro/Currency board & \\
\hline
\end{tabular}

Notes: Reference currencies are the US Dollar, the DM and the Euro

\section{Finland}

\begin{tabular}{|c|c|c|}
\hline Date & $\begin{array}{l}\text { Classification } \\
\text { Primary/Secondary/Tertiary }\end{array}$ & Comments \\
\hline March 1933- October 26, 1939 & Peg to Pound Sterling & Foreign exchange controls are introduced. \\
\hline 1940-June 1944 & Peg to US Dollar/Parallel & \\
\hline July 1944-April 1948 & Freely falling/Parallel market & $\begin{array}{l}\text { Premium above } 200 \text { on July } 1949 \text {. Official rate is pegged to } \\
\text { US Dollar. }\end{array}$ \\
\hline May 1948-June 11, 1951 & Peg to US Dollar/Parallel market & \\
\hline June $11,1951-$ October 12,1967 & $\begin{array}{l}\text { De facto band around US } \\
\text { Dollar/Multiple rates }\end{array}$ & $\begin{array}{l}\text { Band width is }+/-5 \% \text {. Premiums in } 50-130 \% \text { range are the } \\
\text { norm through } 1957 \text {. In June } 1958 \text { premiums reach single } \\
\text { digits for the first time. }\end{array}$ \\
\hline October 12, 1967-January, 1973 & Peg to US Dollar & \\
\hline January 1973-September 8, 1992 & De facto band around DM & $\begin{array}{l}\text { Band width is }+/-2 \% \text {. Officially pegged to a basket of } \\
\text { currencies or the ECU during this period. }\end{array}$ \\
\hline September 8, 1992-March 1993 & Freely falling/Managed floating & ERM crisis \\
\hline April 1993-December 1994 & De facto moving band around DM & Band width is $+/-2 \%$. \\
\hline January 1995-January 1, 1999 & De facto peg to DM & \\
\hline January 1, 1999-December 2001 & Currency union & Euro \\
\hline
\end{tabular}

Notes: Specifics on the evolution of the currency basket, EMS, etc. are available from the detailed chronologies. Reference currencies are the US Dollar, the DM and the Euro 
France

\begin{tabular}{|l|}
\hline Date \\
\hline September 9, 1939- May 17, 1940 \\
\hline May 17, 1940-May 1944 \\
\hline June 1944-December 26, 1945 \\
\hline December 26, 1945-January 26, 1948 \\
\hline January 26, 1948-December 1948 \\
\hline January 1949-June 1956 \\
\hline July 1956-December 13, 1968
\end{tabular}

December 13, 1968- August 8, 1969

August 8, 1969-December 1970

January 1971-August 21, 1971

August 21, 1971-March 19, 1973

March 19, 1973-March 21, 1974

March 21, 1974-June 1974

July, 1974-March 13, 1979

March 13,1979-December 1986

January 1987-January 1, 1999-

January 1, 1999-December 2001
Classification

Primary/Secondary/Tertiary

Peg

Peg to Reichsmark

Peg to Reichsmark/Freely falling

Freely falling/Managed

floating/Parallel Market

Freely falling/Managed

floating/Parallel Market

De facto crawling band around US

Dollar/Multiple rates

De facto band around US

Dollar/Multiple rates

Peg to US Dollar

De facto band around US Dollar/Dual market

Peg to US Dollar

De facto band around DM/Dual market

Pre-announced band/Dual Market

Managed floating

De facto moving band around DM

De facto crawling peg to DM

De facto peg to DM

Currency union

\section{Comments}

Capital controls froze the exchange rate of the Franc versus the US Dollar and Pound Sterling.

Officially pegged to US Dollar. Through 1953 premiums were in the $50-200 \%$ range.

Band width is $+/-5 \%$.

Band width is $+/-2 \%$. Through 1957 the premium oscillated in the $10-40 \%$ range.

Temporary unification.

Band width is $+/-2 \%$. Parallel market premium in single digits.

Band width is $+/-2 \%$.

Band width is $+/-2.25 \%$. Parallel market premium in single digits. Common Margins agreement.

Band width is $+/-2 \%$.

Officially pegged to the ECU

Officially pegged to the ECU

Euro

the US Dollar, the DM and the Euro.

Gabon

Bank of Central African States: Cameroon, Central African Republic, Chad, and Republic of Congo Date

June 6, 1925- February 8, 1944 Primary/Secondary/Tertiary

Peg to French Franc

Comments

Only notes issued by Banque de l'Afrique Occidental are sole legal tender. Exchange controls are introduced within Franc Zone on September 9, 1939.

February 8, 1944- December 26. 1945

December 26. 1945 - January 17, 1962

January 17, 1962-September 9, 1971

Peg to US Dollar and Pound Sterling

On March 19, 1941 incorporated in the Sterling Area

Peg to French Franc

Peg to French Franc

De facto peg to French Franc/Dual

Market

March 21, 1974-December 1993

January 1994-December 1994.

January 1995-January 1, 1999

January 1, 1999-December 2001

Peg to French Franc

Peg to French Franc/Freely falling

Peg to French Franc

Peg to Euro

Notes: Reference currencies are the US Dollar, the French Franc and the Euro.

Gambia

\begin{tabular}{|l|l|l|}
\hline Date & $\begin{array}{l}\text { Classification } \\
\text { Primary/Secondary/Tertiary }\end{array}$ & Comments \\
\hline 1916- May 13, 1964 & Currency board/ Peg to Pound Sterling & $\begin{array}{l}\text { West Africa Pound is introduced by the West African } \\
\text { Currency Board }\end{array}$ \\
\hline May 13, 1964-July 1, 1971 & Currency board/ Peg to Pound Sterling & Gambia Pound replaces West Africa Pound \\
\hline July 1, 1971-December 1980 & Currency board/ Peg to Pound Sterling & Dalasi replaces Gambia Pound \\
\hline January 1981-December 1985 & Multiple Rates/parallel market & $\begin{array}{l}\text { Cannot classify, as parallel market data is not available for } \\
\text { this period }\end{array}$ \\
\hline January 1986-January 20, 1986 & $\begin{array}{l}\text { Freely falling/Multiple Rates/Freely } \\
\text { floating }\end{array}$ & \\
\hline January 20, 1986-February 1987 & Freely falling/freely floating & \\
\hline March 1987-September 1991 & Freely floating & $\begin{array}{l}\text { Band width is +/-2\%. Maximum parallel market premium is } \\
\text { about 30\%. }\end{array}$ \\
\hline October, 1991-December, 2001 & Dollar & \\
\hline
\end{tabular}

Notes: Reference currencies are the US Dollar and the Pound Sterling.

Return to Franc Zone. CFA Franc is introduced.

Bank of Central African States is Created

Parallel market premium in single digits.

One $100 \%$ devaluation.

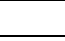

ron


Georgia

\section{Date}

January 1991-April 1993

April, 1993-September 1996

October 1996-December 7, 1998

December 7, 1998-December 2001

Notes: Reference currencies are the US Dollar and the Ruble.

Germany

\section{Date}

July 13, 1931-April 1945

April 1945-June 20, 1948

June 20, 1948-March 31, 1951

March 31, 1951-April 1,1954

April 1, 1954-December 29, 1958

December 29, 1958- September 30, 1969

September 30, 1969-October 26, 1969

October 26,1969-May 10, 1971

May 10, 1971- December 21, 1971

December 21, 1971-January 1973

January 1973-January 1, 1999

January 1, 1999-December 2001

Notes: Specifics on the common margins (snake) agreement, EMS, etc. are available from the detailed chronologies. Reference currencies are the US Dollar, Yen and the Pound Sterling.

Ghana

\begin{tabular}{|c|c|c|}
\hline Date & $\begin{array}{l}\text { Classification } \\
\text { Primary/Secondary/Tertiary }\end{array}$ & Comments \\
\hline July $19,1965-$ November 4,1971 & Peg to Pound Sterling/Parallel Market & $\begin{array}{l}\text { The Cedi replaced the Ghana Pound. The new Cedi was } \\
\text { introduced in } 1967 .\end{array}$ \\
\hline November 4, 1971-September 1973 & Managed floating/Parallel market & The Cedi is officially pegged to US Dollar. \\
\hline October 1973- June 19, 1978 & $\begin{array}{l}\text { Freely Falling/Managed } \\
\text { floating/Parallel market }\end{array}$ & $\begin{array}{l}\text { The Cedi is officially pegged to US Dollar. There are } \\
\text { multiple exchange rates. }\end{array}$ \\
\hline June 1984-April 1986 & Freely floating/Parallel market & There are multiple exchange rates. \\
\hline May 1986-September 19, 1986 & $\begin{array}{l}\text { Freely falling/Freely floating/Parallel } \\
\text { Market }\end{array}$ & There are multiple exchange rates. \\
\hline September 19, 1986-September 1987 & $\begin{array}{l}\text { Freely falling/Freely floating/Dual } \\
\text { Market }\end{array}$ & There are multiple exchange rates. \\
\hline October 1990-February 1994 & Managed floating & $\begin{array}{l}\text { There are multiple exchange rates. Since early 1993, the } \\
\text { parallel market premia has been in single digits. }\end{array}$ \\
\hline March 1994-July 1996 & Freely falling/Managed floating & \\
\hline August 1996-October 1999 & Managed floating & \\
\hline November 1999-March 2001 & Freely falling/Managed floating & \\
\hline April 2001-December 2001 & Managed floating & \\
\hline
\end{tabular}

Notes: Formerly Gold Coast. Reference currencies are the US Dollar, the Pound Sterling, and the South African Rand.

\begin{tabular}{|l|}
\hline Comments \\
\hline Russian Ruble \\
\hline September 1993-September 1994 regime is a "hyper float." \\
\hline
\end{tabular}

De facto moving band around US

Peg to US Dollar/Parallel Market

Mini-Float

Peg to US Dollar

Managed floating

Peg to US Dollar

Comments

Foreign exchange controls are introduced. There are several quasi currencies in circulation. In 1936 capital flight warranted the death penalty.

Officially Reichsmark is pegged to the US Dollar.

The parallel market premia is $2,000-3,200 \%$ during this period

Band width is $+/-5 \%$. Reference currency is the US Dollar, The Deutschemark replaces the Reichsmark. The parallel premium oscillates in the 50-500\% range through 1949 and in the $20-50 \%$ range through mid- 1952 .

Band width is $+/-5 \%$. Introduction of a quasi currency the Sperrmark.

Introduction of a second quasi currency the Bekomark.

Parallel market premia is trivial after mid-1955.

The Deutschemark fully convertible Bekomark abolished. The Sperrmark had been consolidated in 1954 .

\section{Classification}

Primary/Secondary/Tertiary

Multiple exchange rates

Managed floating/Multiple rates

De facto moving band around US

Dollar/Multiple rates

Dollar/Multiple rates

De facto peg to US Dollar/Multiple rates

Float

Currency Union

\section{/Secondary/Tertiary}

Classification

Primary/Secondary/Tertiary

Peg to Pound Sterling/Parallel Market

Freely falling/Freely floating/Parallel

Market

Freely falling/Managed floating/Dual

Freely falling/Managed floating

Freely falling/Managed floating

Managed floating uro

\begin{tabular}{|l|}
\hline \\
\hline \\
\hline
\end{tabular}


Greece

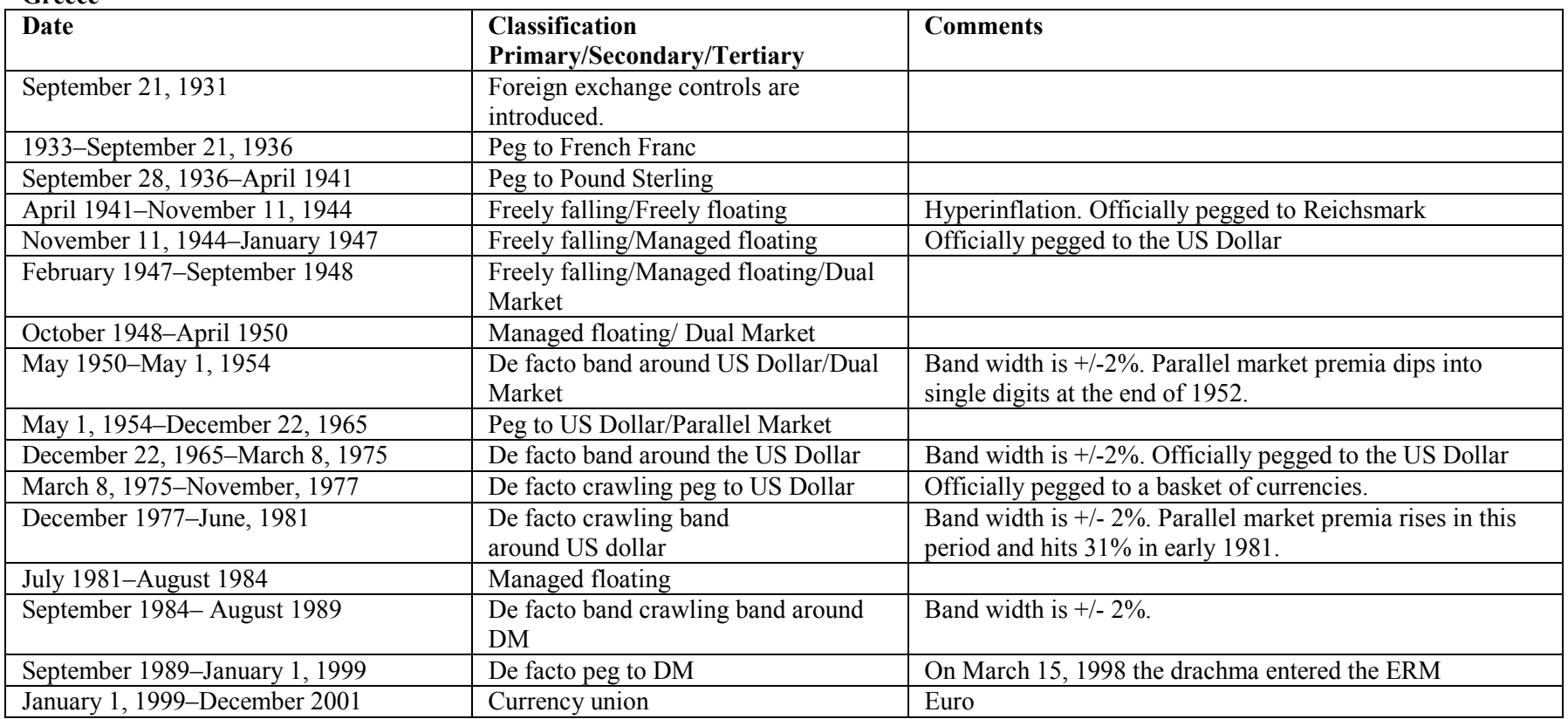

Notes: Reference currencies are the US Dollar, the Pound Sterling, and the DM and the Euro.

Grenada

East Caribbean Central Bank States are: Anguilla, Antigua and Barbuda, Dominica, Grenada, Montserrat, Saint Kitts and Nevis, Saint Lucia, Saint Vincent and the Grenadines

\begin{tabular}{|l|l|l|}
\hline Date & $\begin{array}{l}\text { Classification: } \\
\text { Primary/Secondary/Tertiary }\end{array}$ & Comments \\
\hline 1935-October 6, 1965 & Peg to Pound Sterling & $\begin{array}{l}\text { British West Indies Dollar is introduced. It is issued by the } \\
\text { East Caribbean Monetary Authority. }\end{array}$ \\
\hline October 6, 1965-July 7, 1976 & Peg to Pound Sterling & East Caribbean Dollar replaces British West Indies Dollar. \\
\hline July 7, 1976-December 2001 & Peg to US Dollar & $\begin{array}{l}\text { ON October 1, 1983 the East Caribbean Central Bank } \\
\text { replaces the East Caribbean Monetary Authority. }\end{array}$ \\
\hline
\end{tabular}

Notes: Reference currency is US Dollar.

Guatemala

\begin{tabular}{|l|l|l|}
\hline Date & $\begin{array}{l}\text { Classification: } \\
\text { Primary/Secondary/Tertiary }\end{array}$ & Comments \\
\hline November 26,1926-October 13,1962 & Peg to US Dollar & The Quetzal replaces the Guatemalan Peso. \\
\hline October 13, 1963-May 25,1963 & Multiple Rates & $\begin{array}{l}\text { Foreign exchange controls were introduced. There is no } \\
\text { data on the parallel rate for this period. }\end{array}$ \\
\hline May 1963-November 16, 1984 & Peg to US Dollar/Parallel market & $\begin{array}{l}\text { There are three rates. There is no data on the parallel rate } \\
\text { for this period. }\end{array}$ \\
\hline November 16, 1984-March, 1985 & Multiple exchange rates & Multiple exchange rates \\
\hline March, 1985-June 1986 & $\begin{array}{l}\text { Freely falling/Managed } \\
\text { floating/Parallel Market }\end{array}$ & Parallel market premium hits 400\%. \\
\hline July 1986-June 23, 1988 & Managed floating/Multiple rates & $\begin{array}{l}\text { De facto crawling peg to US } \\
\text { Dollar/Multiple rates }\end{array}$ \\
\hline June 23, 1988-May 1989 & $\begin{array}{l}\text { Freely falling/De facto crawling band } \\
\text { around US Dollar }\end{array}$ & Band width is +/-2\%. There are multiple rates. \\
\hline June 1989-April 1991 & De facto crawling peg to US Dollar & Parallel market premia is in single digits during this period. \\
\hline May 1991-December 2001
\end{tabular}

Notes: Reference currency is the US Dollar. 
Guinea

\begin{tabular}{|c|c|c|}
\hline Date & $\begin{array}{l}\text { Classification: } \\
\text { Primary/Secondary/Tertiary }\end{array}$ & Comments \\
\hline July 21, 1934-September 9, 1939 & Peg to French Franc & Controls are introduced in 1939 in the CFA Franc Zone. \\
\hline February 2 1943-December 6, 1944 & Peg to US Dollar and Pound Sterling & Incorporated into Sterling Area \\
\hline December 6, 1944-March 1, 1960 & Peg to French Franc & Return to Franc Zone. \\
\hline March 1, 1960-December 1970 & Peg to US Dollar & $\begin{array}{l}\text { Parallel Market .The Guinea Franc replaced the CFA Franc } \\
\text { withdrawal from CFA Franc zone. On October 2, 1972, the } \\
\text { Syli replaced the Guinean Franc. }\end{array}$ \\
\hline January 1971-June 11, 1975 & De facto band around US Dollar & $\begin{array}{l}\text { Band width is }+/-5 \% \text {. The official rate remains pegged to } \\
\text { the US Dollar but the parallel market is active with } \\
\text { premiums occasionally of over } 1,000 \% \text {. }\end{array}$ \\
\hline June 11,1975 -October 1978 & De facto moving peg to US Dollar & Officially pegged to the SDR. Active parallel market \\
\hline November 1978 December 1, 1982- & $\begin{array}{l}\text { De facto crawling band around US } \\
\text { Dollar }\end{array}$ & $\begin{array}{l}\text { Officially pegged to the SDR. } \\
\text { Band width is }+/-2 \% \text { for the official rate. The parallel rate } \\
\text { oscillates within a wider }+/-5 \% \text { band. }\end{array}$ \\
\hline December 1, 1982-October 7, 1985 & $\begin{array}{l}\text { Parallel Market/De facto crawling } \\
\text { band around US Dollar }\end{array}$ & Band width is $+/-5 \%$. There are multiple exchange rates. \\
\hline October 7, 1985-June 1, 1986 & $\begin{array}{l}\text { Freely falling/De facto crawling band } \\
\text { around US Dollar/Dual Market }\end{array}$ & $\begin{array}{l}\text { Band width is }+/-5 \% \text {. Officially pegged to the SDR. On } \\
\text { January } 1986 \text {, the currency was devalued by } 1,235 \% \text {. The } \\
\text { Guinean Syli was replaced by the New Guinean Franc. On } \\
\text { December } 1985 \text { the parallel market premia had reached } 1 \text {, } \\
423 \% \text {. There are multiple exchange rates. }\end{array}$ \\
\hline June 1, 1986-December 1986 & Peg to US Dollar/Freely falling & \\
\hline January $1987-$ February 1,1991 & Peg to US Dollar & Frequent adjustments \\
\hline February 1, 1991-May 1991 & $\begin{array}{l}\text { De facto crawling band around US } \\
\text { Dollar }\end{array}$ & Band width is $+/-2 \%$. Officially pegged to the SDR \\
\hline June 1991-September, 1999 & De facto crawling peg to US Dollar & \\
\hline September, 1999-April, 2000 & $\begin{array}{l}\text { De facto crawling band around US } \\
\text { Dollar }\end{array}$ & Band width is $+/-2 \%$. \\
\hline May 2000-December 2001 & Managed floating & \\
\hline
\end{tabular}

Notes: Formerly French Guinea.

Guinea-Bissau

Central Bank of West African States: Benin, Burkina Faso, Cote D'Ivoire, Guinea-Bissau, Mali, Niger, Senegal, and Togo ${ }^{1}$

\begin{tabular}{|l|l|l|}
\hline Date & $\begin{array}{l}\text { Classification: } \\
\text { Primary/Secondary/Tertiary }\end{array}$ & Comments \\
\hline 1879-February 29, 1976 & $\begin{array}{l}\text { Currency arrangement with no } \\
\text { separate legal tender }\end{array}$ & Portugese Escudo \\
\hline February 29, 1976-May 26, 1978 & Peg to Portugese Escudo & Introduction of Guinea-Bissau Peso. \\
\hline May 26, 1978-December 23, 1983 & Peg to SDR & \\
\hline December 23, 1983-December 1992 & Crawling peg to SDR & $\begin{array}{l}\text { There are multiple exchange rates. No data on parallel } \\
\text { market. }\end{array}$ \\
\hline January 1993-May 2, 1997 & Parallel Market/Dual Market & $\begin{array}{l}\text { Joined the CFA Franc Zone. The Guinea Bissau Peso was } \\
\text { converted to the CFA Franc through July 31, 1997. }\end{array}$ \\
\hline May 2, 1997-January 1, 1999 & Peg to French Franc & \\
\hline January 1, 1999-December 2001 & Peg to Euro & \\
\hline
\end{tabular}

${ }^{1}$ Mali joined the currency arrangement on June 1, 1984. Reference currencies are the French Franc and the Euro. 
Guyana

\begin{tabular}{|c|c|c|}
\hline Date & $\begin{array}{l}\text { Classification: } \\
\text { Primary/Secondary/Tertiary }\end{array}$ & Comments \\
\hline 1935-November 15, 1965 & $\begin{array}{l}\text { Exchange arrangement with no } \\
\text { separate legal tender }\end{array}$ & British West Indies Dollar is pegged to Pound Sterling \\
\hline November 15,1965 -October 9, 1975 & Peg to Pound Sterling & $\begin{array}{l}\text { Guyana Dollar was issued to replace British West Indies } \\
\text { Dollar }\end{array}$ \\
\hline October 9, 1975-June 21982 & Peg to US Dollar/Parallel Market & \\
\hline June 2, 1982-February 2, 1987 & $\begin{array}{l}\text { De facto crawling peg to the US } \\
\text { Dollar }\end{array}$ & $\begin{array}{l}\text { Officially the Guyana Dollar is repegged to a basket of } \\
\text { currencies. Multiple exchange rates prevail except in } 1985 . \\
\text { There is an active parallel market. In effect, through } 1991 \\
\text { it is a system where the official exchange rate is pegged to } \\
\text { the US Dollar and devalued frequently. }\end{array}$ \\
\hline January 1988-March 13, 1990 & $\begin{array}{l}\text { Freely falling/De facto crawling band } \\
\text { around US Dollar/Parallel Market }\end{array}$ & $\begin{array}{l}\text { Band width is }+/-5 \% \text {. The premium surpassed } 1,100 \% \text { in } \\
\text { late } 1986 \text { on the eve of the January } 1987 \text { devaluation. }\end{array}$ \\
\hline March 13, 1990-April 1, 1991 & $\begin{array}{l}\text { Freely falling/De facto crawling band } \\
\text { around US Dollar/Dual Market }\end{array}$ & $\begin{array}{l}\text { Band width is }+/-5 \% \text {. On March } 13,1990 \text { the parallel } \\
\text { market was legalized creating an official dual arrangement. }\end{array}$ \\
\hline April 1, 1991-December 1991 & $\begin{array}{l}\text { Freely falling/De facto crawling band } \\
\text { around US Dollar }\end{array}$ & Markets were unified. Band width is $+/-5 \%$. \\
\hline January 1995-December, 2001 & $\begin{array}{l}\text { De facto crawling peg around US } \\
\text { Dollar }\end{array}$ & $\begin{array}{l}\text { Since January } 1995 \text { parallel market premia have remained } \\
\text { in single digits. }\end{array}$ \\
\hline
\end{tabular}

Notes: Formerly British Guiana. Reference currency is the US Dollar.

Haiti

\begin{tabular}{|l|l|l|}
\hline Date & $\begin{array}{l}\text { Classification: } \\
\text { Primary/Secondary/Tertiary }\end{array}$ & Comments \\
\hline September 16, 1915-December 1984 & Peg to US Dollar & $\begin{array}{l}\text { US Dollar also legal tender, although there was no black } \\
\text { market, premiums in the 10-15\% range were offered for } \\
\text { payments New York post 1958. }\end{array}$ \\
\hline January 1985-April 1989 & $\begin{array}{l}\text { De facto crawling band around US } \\
\text { Dollar/Parallel market }\end{array}$ & $\begin{array}{l}\text { Band width is +/-2\%. The official rate is pegged to the US } \\
\text { Dollar }\end{array}$ \\
\hline May 1989-September 16, 1991 & $\begin{array}{l}\text { De facto crawling band around US } \\
\text { Dollar /Parallel market }\end{array}$ & $\begin{array}{l}\text { Premia peaked at 300\% prior to the abandonment of the } \\
\text { peg. Band width +/-5\%. The official rate remains pegged } \\
\text { to the US Dollar through September 16. }\end{array}$ \\
\hline September 16, 1991-March 1992 & $\begin{array}{l}\text { Freely falling/Crawling band around } \\
\text { US Dollar }\end{array}$ & Band width +/-5\%. \\
\hline March 1992- May 1993 & Crawling band around US Dollar & Band width +/-5\%. \\
\hline May 1993-February 1995 & Freely falling/Freely floating & $\begin{array}{l}\text { Despite its floating status the parallel premia remained near } \\
50 \% \text { through end-1998 }\end{array}$ \\
\hline March 1995-December 2001 & Freely floating & \\
\hline
\end{tabular}

Notes: Reference currency is the US Dollar.

Honduras

\begin{tabular}{|c|c|c|}
\hline Date & $\begin{array}{l}\text { Classification: } \\
\text { Primary/Secondary/Tertiary }\end{array}$ & Comments \\
\hline 1918- April 3, 1926 & Peg to US Dollar & \\
\hline April 3, 1926-March 27, 1934 & Peg to US Dollar & The Lempira replaces the Honduras Peso. \\
\hline March 27, 1934-June 30, 1950 & Dual Market & Capital controls are introduced. \\
\hline June 30, 1950- March 19, 1985 & Peg to US Dollar & Controls were lifted. \\
\hline March 19, 1985-March 13, 1990 & $\begin{array}{l}\text { De facto crawling band around US } \\
\text { Dollar/Parallel Market }\end{array}$ & $\begin{array}{l}\text { Band width is }+/-5 \% \text {. There are multiple rates. } \\
\text { Parallel market premium peaks at } 143 \% \text { just before the } \\
\text { devaluation. }\end{array}$ \\
\hline March 13,1990-September 3, 1990 & $\begin{array}{l}\text { Freely falling/De facto crawling band } \\
\text { around US Dollar }\end{array}$ & $\begin{array}{l}\text { In September 3, } 1990 \text { a dual market was introduced. Band } \\
\text { width is }+/-5 \% \text {. }\end{array}$ \\
\hline September 3, 1990-March 1991 & $\begin{array}{l}\text { Freely falling/De facto crawling band } \\
\text { around US Dollar/Dual Market }\end{array}$ & Band width is $+/-5 \%$. \\
\hline April 1991-June 18, 1992 & $\begin{array}{l}\text { De facto crawling band around US } \\
\text { Dollar/Dual Market }\end{array}$ & Band width is $+/-5 \%$. \\
\hline June $18,1992-$ January 1996 & $\begin{array}{l}\text { De facto crawling band around US } \\
\text { Dollar }\end{array}$ & Band width is $+/-5 \%$. \\
\hline January 1996-December 1998 & $\begin{array}{l}\text { De facto crawling band around the US } \\
\text { Dollar/Dual Market }\end{array}$ & $\begin{array}{l}\text { Band width is }+/-5 \% \text {. Parallel market premia has been in } \\
\text { single digits since } 1993 \text {. The official rate is a de facto } \\
\text { crawling peg. }\end{array}$ \\
\hline January 1999-December 2001 & De facto crawling peg to US Dollar & There is an official $+/-7 \%$ band. \\
\hline
\end{tabular}

Notes: Reference currency is the US Dollar. 
Hong Kong

\begin{tabular}{|c|c|c|}
\hline Date & $\begin{array}{l}\text { Classification: } \\
\text { Primary/Secondary/Tertiary }\end{array}$ & Comments \\
\hline December 5, 1935, 1941- January 5, 1942 & Peg to Pound Sterling & \\
\hline January 5, 1942- December 19,1946 & Peg to Yen & \\
\hline $\begin{array}{l}\text { December 19, 1946- September 18, } \\
1949\end{array}$ & Peg to Pound Sterling & Parallel rate peaks at $79 \%$ just before the peg is abandoned. \\
\hline September 18, 1949-August 22. 1962 & $\begin{array}{l}\text { De facto band around Pound } \\
\text { Sterling/Multiple Rates }\end{array}$ & Band width is $+/-5 \%$. \\
\hline August 22. 1962- July 6, 1972 & Peg to Pound Sterling & \\
\hline July $6,1972-$ October 17,1983 & $\begin{array}{l}\text { De facto moving band around US } \\
\text { Dollar/Dual Markets }\end{array}$ & $\begin{array}{l}\text { Band width is }+/-2 \% \text {. An Official and an Effective } \\
\text { exchange rate were in place. Parallel market premia is trivial }\end{array}$ \\
\hline October 17, 1983-December 2001 & Currency board/Peg to US Dollar & \\
\hline
\end{tabular}

Notes: Reference currencies are the Pound Sterling and the US Dollar.

Hungary

\begin{tabular}{|l|l|l|}
\hline Date & $\begin{array}{l}\text { Classification: } \\
\text { Primary/Secondary/Tertiary }\end{array}$ & Comments \\
\hline August 1, 1946-April 1, 1957 & Peg/Parallel market & $\begin{array}{l}\text { Hungary entered Ruble zone and the Forint replaced the } \\
\text { Pengoe. }\end{array}$ \\
\hline April 1, 1957-July 1,1992 & $\begin{array}{l}\text { De Facto crawling band around the } \\
\text { DM/Multiple rates }\end{array}$ & $\begin{array}{l}\text { Band width is +/- 5\%. Officially pegged to a basket of } \\
\text { currencies. On December 1, 1991 the basket was changed } \\
\text { to comprise the ECU and the US Dollar with equal weights. }\end{array}$ \\
\hline July 1, 1992-May 16, 1994 & $\begin{array}{l}\text { De Facto crawling band around the } \\
\text { DM }\end{array}$ & $\begin{array}{l}\text { Band width is +/- 5\%. On August 2, 1993 the DM replaced } \\
\text { the ECU. }\end{array}$ \\
\hline May 16, 1994 1994-January 1, 1999 & $\begin{array}{l}\text { De Facto crawling band around the } \\
\text { DM }\end{array}$ & $\begin{array}{l}\text { Band width is +/-2\%. At this time the weight of the DM in } \\
\text { the basket was increased to 70\%. }\end{array}$ \\
\hline January 1, 1999-December 2001 & $\begin{array}{l}\text { Pre-Announced crawling band around } \\
\text { the Euro }\end{array}$ & Band width is +/- 2.25\%. \\
\hline
\end{tabular}

Notes: Reference currencies are the DM, the Euro, the Ruble and the US Dollar.

Iceland

\begin{tabular}{|c|c|c|}
\hline Date & $\begin{array}{l}\text { Classification: } \\
\text { Primary/Secondary/Tertiary }\end{array}$ & Comments \\
\hline October 1925-December 18, 1946 & Peg to Pound Sterling & Joined Sterling Area \\
\hline December 18, 1946-March 8, 1951 & Peg to US Dollar/Parallel market & $\begin{array}{l}\text { De facto devalued with Pound Sterling. Parallel market } \\
\text { premia as high as } 285 \% \text {. }\end{array}$ \\
\hline March 8, 1951-October 1968 & $\begin{array}{l}\text { De facto crawling band around US } \\
\text { Dollar/Parallel Market }\end{array}$ & $\begin{array}{l}\text { Band width is }+/-2 \% \text {. Until late } 1962 \text { premia is in high } \\
\text { double digits. There are multiple exchange rates. }\end{array}$ \\
\hline November 1968-April 1973 & $\begin{array}{l}\text { De facto crawling band around US } \\
\text { Dollar/Parallel Market }\end{array}$ & Band width is $+/-2 \%$. There are multiple exchange rates. \\
\hline May 1973-January 1976 & $\begin{array}{l}\text { Freely falling/De facto crawling band } \\
\text { around US Dollar/Parallel Markets }\end{array}$ & Band width is $+/-5 \%$. There are multiple exchange rates. \\
\hline February 1976-April 1977 & $\begin{array}{l}\text { De facto crawling band around US } \\
\text { Dollar/Parallel Market }\end{array}$ & $\begin{array}{l}\text { Band width is }+/-5 \% \text {. Officially pegged to a basket of } \\
\text { currencies. } \\
\text { There are multiple exchange rates }\end{array}$ \\
\hline May $1977-$ July 29,1983 & $\begin{array}{l}\text { Freely falling/Managed floating/Dual } \\
\text { Markets }\end{array}$ & Travel Rate is abolished. \\
\hline July 29, 1983-May 1984 & $\begin{array}{l}\text { Freely falling/De facto crawling band } \\
\text { around DM }\end{array}$ & Band width is $+/-5 \%$. \\
\hline June 1984-September 1986 & De facto crawling band around DM. & $\begin{array}{l}\text { Band width is }+/-5 \% \\
\text { Officially pegged to a basket of currencies. }\end{array}$ \\
\hline September 1986-October 2000 & De facto crawling band around DM. & $\begin{array}{l}\text { Band width is }+/-2 \% \text {. Officially pegged to a basket of } \\
\text { currencies. During this period the weight attached to the } \\
\text { US Dollar is declining. On January 3,1992, the ECU has a } \\
\text { weight of } 76 \% \text {. }\end{array}$ \\
\hline October 2000-March 28, 2001 & De facto managed floating & Officially pegged to a basket of currencies \\
\hline March 28, 2001-December 2001 & Managed floating & \\
\hline
\end{tabular}

Notes: Reference currency is the US Dollar. 
India

\begin{tabular}{|c|c|c|}
\hline Date & $\begin{array}{l}\text { Classification: } \\
\text { Primary/Secondary/Tertiary }\end{array}$ & Comments \\
\hline August 1914-March 22, 1927 & Peg to Pound Sterling & Convertibility into sterling is suspended. \\
\hline March 22, 1927-September 24, 1931 & Peg & Gold Standard \\
\hline September 24, 1931-September 3, 1939 & Peg to Pound Sterling & Suspension of Gold Standard adherence to Sterling Area. \\
\hline September 3, 1939-October 1941 & Peg to Pound Sterling & Capital controls are introduced \\
\hline November 1941-October 1943 & Peg to Pound Sterling/Freely falling & \\
\hline November 1943-October 1, 1965 & Peg to Pound Sterling & \\
\hline October 1, 1965-June 6, 1966 & $\begin{array}{l}\text { De facto band around Pound } \\
\text { Sterling/Parallel Market }\end{array}$ & There are multiple exchange rates. Band width is $+/-5 \%$. \\
\hline June 6, 1966-August 23, 1971 & Peg to Pound Sterling & \\
\hline August 23, 1971-December 20, 1971 & Peg to US Dollar & \\
\hline December 20, 1971-September 25, 1975 & Peg to Pound Sterling & \\
\hline September 25, 1975-February 1979 & $\begin{array}{l}\text { De facto crawling band around Pound } \\
\text { Sterling }\end{array}$ & $\begin{array}{l}\text { Band width is }+/-2 \% \text {. Officially pegged to a basket of } \\
\text { currencies. }\end{array}$ \\
\hline March 1979-July 1979 & Managed floating & \\
\hline August 1979-July 1989 & $\begin{array}{l}\text { De facto crawling band around US } \\
\text { dollar. }\end{array}$ & $\begin{array}{l}\text { Band width is }+/-2 \% \text {. Officially pegged to a basket of } \\
\text { currencies }\end{array}$ \\
\hline August 1989-July 1991 & De facto crawling peg to US dollar & \\
\hline August 1991-June 1995 & De facto peg to US dollar & $\begin{array}{l}\text { One devaluation on March } 1993 \text { - parallel market premia } \\
\text { rose to } 27 \% \text { in February. }\end{array}$ \\
\hline July 1995-December 2001 & De facto crawling peg to US dollar & $\begin{array}{l}\text { During this period the parallel market premium has been } \\
\text { consistently in single digits. }\end{array}$ \\
\hline
\end{tabular}

Notes: Reference currencies are the US Dollar and the Pound Sterling.

Indonesia

\begin{tabular}{|c|c|c|}
\hline Date & $\begin{array}{l}\text { Classification: } \\
\text { Primary/Secondary/Tertiary }\end{array}$ & Comments \\
\hline 1877- September 1940 & Peg & Gold Standard \\
\hline September 1940-1942 & Peg to Pound Sterling & $\begin{array}{l}\text { Peg to Sterling following German occupation of the } \\
\text { Netherlands. }\end{array}$ \\
\hline 1942- September 1945 & Peg to Yen & Military Yen (Gumpyo) is introduced. \\
\hline September 1945-March 7, 1946 & Peg to Pound Sterling/Parallel Market & \\
\hline March 7, 1946-November 2, 1949 & Peg to Netherlands Guilder & $\begin{array}{l}\text { Indonesian Guilder, formerly Netherlands East Indies } \\
\text { Guilder, re-circulates. }\end{array}$ \\
\hline November 2, 1949-December 1949 & Managed floating & $\begin{array}{l}\text { The Rupiah replaces the Indonesian or Netherlands East } \\
\text { Indies Guilder. Reference currency is the US Dollar. There } \\
\text { are multiple exchange rates }\end{array}$ \\
\hline October 1950-January 1952 & Freely falling/Managed floating & Inflation is $68 \%$. There are multiple exchange rates \\
\hline February 1952-August 1954 & Managed floating & \\
\hline September 1954-November 1955 & Freely falling/Managed floating & \\
\hline December 1955-March 1969 & Managed floating & $\begin{array}{l}\text { Escalating instability in early } 1960 \text { 's the parallel market } \\
\text { premium is } 2,678 \% \text { in July } 1962,5,100 \% \text { in August } 1965 \\
\text { and peaks at } 11,100 \% \text { in November } 1965 \text {. There are } \\
\text { multiple exchange rates. }\end{array}$ \\
\hline April 1969-December 10, 1970 & $\begin{array}{l}\text { De facto crawling band to US } \\
\text { Dollar/Parallel market }\end{array}$ & $\begin{array}{l}\text { Band width is }+/-5 \% \text {. The official rate is pegged to US } \\
\text { Dollar. There are multiple exchange rates. On February } \\
1967 \text { the premium is in single digits for the first time. }\end{array}$ \\
\hline December 10, 1970-August 23, 1971 & Peg to US Dollar & Temporary unification. \\
\hline August 23, 1971-June 1972 & $\begin{array}{l}\text { De facto crawling band to US } \\
\text { Dollar/Parallel market }\end{array}$ & $\begin{array}{l}\text { Band width is }+/-5 \% . \% \text {. The official rate is pegged to US } \\
\text { Dollar. There are multiple exchange rates }\end{array}$ \\
\hline July 1972-December 1973 & $\begin{array}{l}\text { Freely falling/ De facto crawling band } \\
\text { to US Dollar/Parallel market }\end{array}$ & $\begin{array}{l}\text { Band width is }+/-5 \% . \% \text {. The official rate is pegged to US } \\
\text { Dollar. } 1973 \text { was the last year in which multiple rates are } \\
\text { listed by the IMF. }\end{array}$ \\
\hline January 1974-June 1974 & $\begin{array}{l}\text { Freely falling/ De facto crawling band } \\
\text { to US Dollar/Parallel market }\end{array}$ & $\begin{array}{l}\text { Band width is }+/-5 \% . \% \text {. The official rate is pegged to US } \\
\text { Dollar }\end{array}$ \\
\hline July 1974-November 16,1978 & $\begin{array}{l}\text { De facto crawling band to US } \\
\text { Dollar/Parallel market }\end{array}$ & $\begin{array}{l}\text { Band width is }+/-5 \% . \% \text {. The official rate is pegged to US } \\
\text { Dollar }\end{array}$ \\
\hline November 16, 1978-July 1997 & De facto crawling peg to US Dollar & $\begin{array}{l}\text { Officially pegged to a basket of undisclosed currencies. } \\
\text { Premium consistently below } 20 \% \text { and mostly in single digits. }\end{array}$ \\
\hline August, 1997-March 1999 & Freely falling/Freely floating & $\begin{array}{l}\text { A dual rate comes into effect briefly in February } 1998 \text {, when } \\
\text { a subsidized rate was applied to certain food imports. }\end{array}$ \\
\hline April 1999-December 2001 & Freely floating & \\
\hline
\end{tabular}

Notes: Reference currencies are the US Dollar and Yen. 
Iran

\begin{tabular}{|c|c|c|}
\hline Date & $\begin{array}{l}\text { Classification: } \\
\text { Primary/Secondary/Tertiary }\end{array}$ & Comments \\
\hline March 13, 1932-March 1, 1933 & Peg & Silver standard, the Rial replaced the Kran. \\
\hline March 1, 1933-1945 & Peg to Pound Sterling/Parallel Market & Reestablishment of foreign exchange controls. \\
\hline 1945-January 1954 & Dual Market & There are multiple exchange rates. \\
\hline February 1954-May 27,1957 & $\begin{array}{l}\text { De facto band around US Dollar/Dual } \\
\text { Market }\end{array}$ & $\begin{array}{l}\text { Band width is }+/-2 \% \text {. The US Dollar is the reference } \\
\text { currency. }\end{array}$ \\
\hline May $27,1957-$ January 14,1974 & Peg to US Dollar & \\
\hline January 14, 1974-December 1976 & $\begin{array}{l}\text { De facto band around US Dollar/Dual } \\
\text { Market }\end{array}$ & $\begin{array}{l}\text { Band width is }+/-2 \% \text {. On February } 12,1975 \text { the Rial's links } \\
\text { to the US Dollar were officially terminated and the } \\
\text { currency was linked to the SDR. }\end{array}$ \\
\hline $\begin{array}{l}\text { January } 1977-\text { January } 1994 \\
\end{array}$ & Managed floating/Parallel Market & $\begin{array}{l}\text { There are multiple exchange rates during } 1978-1984 \text { and } \\
\text { again } 1990-1994 \text {. Since January } 1987 \text {, the parallel market } \\
\text { premium is consistently above } 1,000 \% \text {. There is a major } \\
\text { devaluation of the official rate in early } 1993 \text {. }\end{array}$ \\
\hline February, 1994-February 1996 & $\begin{array}{l}\text { Freely falling/Managed } \\
\text { floating/Parallel Market }\end{array}$ & $\begin{array}{l}\text { There are multiple exchange rates. After hitting a peak of } \\
3,618 \% \text { on February 1993, the parallel market premium } \\
\text { settles around } 50 \% \text {. }\end{array}$ \\
\hline March 1996-December 2001 & Managed floating/Dual Market & $\begin{array}{l}\text { Three rates reduced to two on March } 31,2000 \text {. The official } \\
\text { rate is a de facto peg to the US Dollar during this period. } \\
\text { Parallel market premium is consistently above } 150 \% \text { and } \\
\text { occasionally above } 200 \% \text {. }\end{array}$ \\
\hline
\end{tabular}

Notes: Reference currency is the US Dollar.

Iraq

\begin{tabular}{|c|c|c|}
\hline Date & $\begin{array}{l}\text { Classification: } \\
\text { Primary/Secondary/Tertiary }\end{array}$ & Comments \\
\hline $1900-1931$ & $\begin{array}{l}\text { Arrangement with no separate legal } \\
\text { tender }\end{array}$ & $\begin{array}{l}\text { Egyptian Pounds and Indian Rupees circulate as legal } \\
\text { tender. }\end{array}$ \\
\hline April 19, 1931-April 1, 1932 & Peg & Gold Standard. Iraqui Dinar is introduced \\
\hline April 1, 1932-June 23, 1959 & Peg to Pound Sterling & $\begin{array}{l}\text { Iraq withdrew from Sterling Area but continued to peg to } \\
\text { Pound Sterling. }\end{array}$ \\
\hline June 23, 1959-June 23, 1972 & $\begin{array}{l}\text { De facto peg to Pound Sterling/Dual } \\
\text { Market }\end{array}$ & \\
\hline July 3, 1972-December 1981 & Peg to US Dollar & Parallel market premia is small during this period. \\
\hline January 1982-December 1998 & Managed floating/Parallel Market & $\begin{array}{l}\text { There are multiple rates in } 1982 \text { and } 1983 \text {. The official } \\
\text { rate is pegged to the US Dollar. There is no data on market } \\
\text { determined rates after this date. }\end{array}$ \\
\hline
\end{tabular}

Notes: Reference currency is the US Dollar. There is no price data.

Ireland

\begin{tabular}{|l|l|l|}
\hline Date & $\begin{array}{l}\text { Classification: } \\
\text { Primary/Secondary/Tertiary }\end{array}$ & Comments \\
\hline August 20, 1927-September 26, 1931 & Peg & Gold \\
\hline September 26, 1931- March 30,1979 & Peg to Pound Sterling & $\begin{array}{l}\text { Adherence to the Sterling area. On September 3, 1939 } \\
\text { foreign exchange controls are introduced. The Irish Pound } \\
\text { remains officially pegged to Pound Sterling but the "green } \\
\text { pound" is applied to a variety of transactions. Until 1976, } \\
\text { the IMF records a dual rate. However, parallel market } \\
\text { premia is nil. }\end{array}$ \\
\hline March 30, 1979-October 1996 & De facto moving band around DM & Band width is +/- 2\%. \\
\hline November, 1996-January 1, 1999 & De facto peg to DM & Euro \\
\hline January 1, 1999-December 2001 & Currency union & \\
\hline
\end{tabular}

Notes: Specifics on the common margins (snake) agreement, EMS, etc. are available from the detailed chronologies. Reference currencies are the DM, the Euro, the Pound Sterling, and the US Dollar. 
Israel

\begin{tabular}{|c|c|c|}
\hline Date & $\begin{array}{l}\text { Classification: } \\
\text { Primary/Secondary/Tertiary }\end{array}$ & Comments \\
\hline August 16, 1948-December 1950 & Peg to Pound Sterling/Parallel Market & $\begin{array}{l}\text { Creation of Israel Pound to replace Palestinian Pound (on } \\
\text { May } 141948 \text { Israel became an independent state). }\end{array}$ \\
\hline January 1951-January 1952 & Freely falling & $\begin{array}{l}\text { Parallel market premia rising steadily_-it peaks in February } \\
1952 \text { at } 678 \% \text {. }\end{array}$ \\
\hline February 17, 1952-February 1962 & Multiple Rates/Parallel Market & $\begin{array}{l}\text { Parallel market premia falls into double digits on July } 1955 . \\
\text { There are multiple rates. }\end{array}$ \\
\hline February 1962-August 17, 1970 & Peg to Pound Sterling & $\begin{array}{l}\text { Beginning November } 1963 \text { parallel market premia } \\
\text { remained mostly in single digits until August } 1968 .\end{array}$ \\
\hline August 17, 1970-September 1973 & Managed floating/Parallel Market & $\begin{array}{l}\text { There are multiple rates. The official rate is linked to the } \\
\text { US Dollar. }\end{array}$ \\
\hline October, 1973-October 28, 1977 & $\begin{array}{l}\text { Freely falling/Managed } \\
\text { floating/Parallel Market }\end{array}$ & $\begin{array}{l}\text { June } 17,1975-\text { July } 8,1976 \text { a crawling peg policy was } \\
\text { announced for the official rate. Premium oscillates in the } \\
20-70 \% \text { range. There are multiple rates. On July } 19,1976 \\
\text { the Israeli Pound was officially linked to a basket of } \\
\text { currencies. }\end{array}$ \\
\hline October 28, 1977-September, 1985 & Freely falling/Managed floating & $\begin{array}{l}\text { Multiple rates abolished and the peg to a basket to a basket } \\
\text { of currencies discontinued. }\end{array}$ \\
\hline October, 1985-August 1986 & $\begin{array}{l}\text { Pre announced crawling band around } \\
\text { US Dollar/ Freely falling }\end{array}$ & Band width is $+/-2 \%$. Inflation stabilization plan. \\
\hline September 1986-December 1986 & $\begin{array}{l}\text { Freely falling/De facto crawling band } \\
\text { around US Dollar }\end{array}$ & $\begin{array}{l}\text { Band width is }+/-2 \% \text {. Inflation stabilization plan continues. } \\
\text { Officially the Shekel is now pegged to a basket of } \\
\text { currencies. }\end{array}$ \\
\hline January 1986-January 3, 1989 & $\begin{array}{l}\text { De facto crawling band around US } \\
\text { Dollar }\end{array}$ & $\begin{array}{l}\text { Band width is }+/-2 \% \text {. Inflation stabilization plan continues. } \\
\text { Officially the Shekel is now pegged to a basket of currencies. }\end{array}$ \\
\hline January 3, 1989-March 1, 1990 & $\begin{array}{l}\text { Pre announced crawling band around } \\
\text { US Dollar }\end{array}$ & $\begin{array}{l}\text { Official band is }+/-3 \% \text { but there is a de facto band that is } \\
\text { narrower }+/-2 \%\end{array}$ \\
\hline March 1, 1990-January 1991 & $\begin{array}{l}\text { De facto crawling band around US } \\
\text { Dollar }\end{array}$ & $\begin{array}{l}\text { Official band width is }+/-5 \% \text {, but de facto band remains at } \\
+/-2 \% \text {. }\end{array}$ \\
\hline February 1991-December 2001 & $\begin{array}{l}\text { De facto crawling band around US } \\
\text { Dollar }\end{array}$ & $\begin{array}{l}\text { Officially, there is a pre announced crawling band around } \\
\text { US Dollar Since July } 261993 \text {, the upper limit is } 6 \% \text { and } \\
\text { the lower is } 2 \% \text { since August } 6,1998 \text {. Hence it is an ever } \\
\text { widening band, which was } 39.2 \% \text { as of December } 30 \text {, } \\
2000 \text {. There is a de facto band width of }+/-5 \% \text {. }\end{array}$ \\
\hline
\end{tabular}

Notes: Reference currency is the US Dollar.

Italy

\begin{tabular}{|c|c|c|}
\hline Date & $\begin{array}{l}\text { Classification: } \\
\text { Primary/Secondary/Tertiary }\end{array}$ & Comments \\
\hline March 29, 1936-June 1943 & Multiple Rates & $\begin{array}{l}\text { The reference currency is the US Dollar. On May 26, } 1934 \\
\text { capital controls are introduced and convertibility is } \\
\text { suspended. }\end{array}$ \\
\hline June 1943- March 26, 1946 & Freely falling/Multiple Rates & $\begin{array}{l}\text { The part of Italy occupied by the Allied forces is pegged to } \\
\text { the US Dollar, the rest pegs to the Reichsmark. }\end{array}$ \\
\hline March 26, 1946-December 1947 & $\begin{array}{l}\text { Freely falling/Managed floating/Dual } \\
\text { Market }\end{array}$ & $\begin{array}{l}\text { There is an active free market and multiple rates. The } \\
\text { parallel premia peaks on May } 1947 \text { at } 41 \% \text {. }\end{array}$ \\
\hline February 1948-September 1951 & Managed floating & There are multiple rates. \\
\hline October 1951-December 29, 1958 & De facto Peg to US Dollar & $\begin{array}{l}\text { There are multiple rates. After April 1952parallel premium } \\
\text { remains in single digits until } 1973 \text {. }\end{array}$ \\
\hline December 29, 1958-June 1, 1959 & De facto peg to US Dollar/Dual Market & \\
\hline June 1, 1959-1969 & Peg to US Dollar & \\
\hline 1969-January 22,1973 & Peg to US Dollar/Parallel Market & \\
\hline January 22, 1973-March 22, 1974 & $\begin{array}{l}\text { De facto crawling band around US } \\
\text { Dollar/Dual Market }\end{array}$ & Band width is $+/-2 \%$. \\
\hline March 22, 1974-September 1975 & $\begin{array}{l}\text { De facto crawling band around US } \\
\text { Dollar }\end{array}$ & Band width is $+/-2 \%$. There are dual rates. \\
\hline October 1975-December 1982 & Managed floating & $\begin{array}{l}\text { There are Dual rates. Different exchange rates arise for } \\
\text { outward transfers of resident-owned capital. }\end{array}$ \\
\hline January 1983-September 13, 1992 & De facto crawling band around DM & Band width is $+/-2 \%$. \\
\hline April 1976-September 13,1992 & De facto crawling band around DM & Band width is $+/-2 \%$. \\
\hline September 13, 1992-March 1993 & Freely falling & \\
\hline April 1993-July 1995 & De facto crawling band around DM & Band width is $+/-2 \%$. \\
\hline August 1995-November 1996 & De facto crawling peg to DM & \\
\hline December 1996-January 1, 1999 & De facto peg to DM & \\
\hline January 1, 1999-December 2001 & Currency union & Euro \\
\hline
\end{tabular}


Notes: Specifics on the common margins (snake) agreement, EMS, etc. are available from the detailed chronologies. Reference currencies are the DM, the Euro, the Pound Sterling, and the US Dollar.

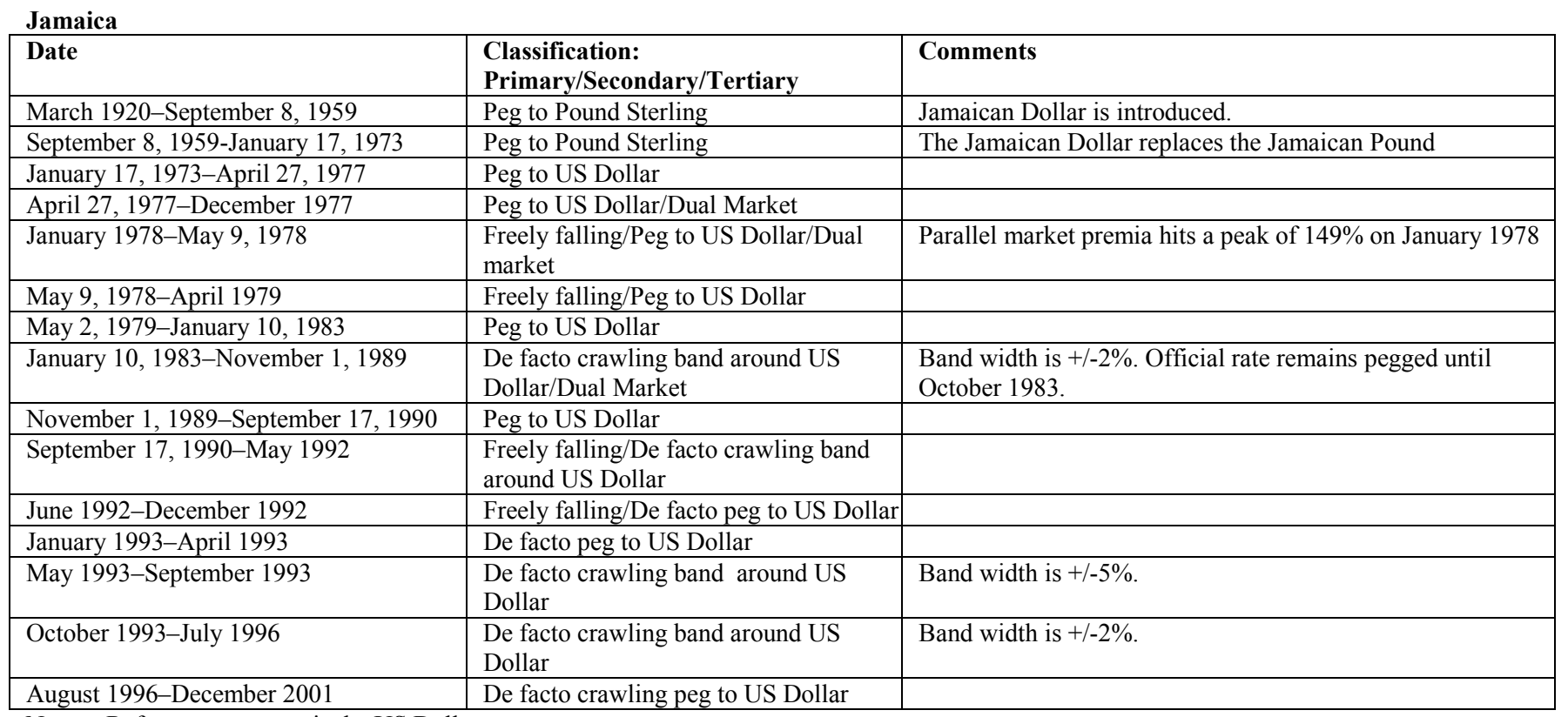

Notes: Reference currency is the US Dollar.

Japan

\begin{tabular}{|c|c|c|}
\hline Date & $\begin{array}{l}\text { Classification: } \\
\text { Primary/Secondary/Tertiary }\end{array}$ & Comments \\
\hline 1933-September 1939 & Peg to Pound Sterling & $\begin{array}{l}\text { On July 1, } 1932 \text { foreign exchange controls are introduced. } \\
\text { The official peg ended on September } 1939 .\end{array}$ \\
\hline December 29, 1941- & Peg to Reischsmark & \\
\hline July, 1944-August 1945 & Peg to Reischsmark/Freely falling & \\
\hline August 1945-June 1946 & $\begin{array}{l}\text { Freely falling/Managed } \\
\text { floating/Parallel market }\end{array}$ & $\begin{array}{l}\text { There are multiple rates. Military exchange rate. Black } \\
\text { market skyrocketed. Official yen } 15 \text { to a dollar-black } \\
\text { market } 875 \text { to the dollar on February } 1946 \text { Inflation was } \\
513 \% \text { in } 1946 \text {. }\end{array}$ \\
\hline July 1949-April 25, 1949 & Managed floating/Parallel Market & There are multiple rates. \\
\hline April 25, 1949-May 11, 1953 & $\begin{array}{l}\text { De facto band around US } \\
\text { Dollar/Parallel Market }\end{array}$ & $\begin{array}{l}\text { Band width is }+/-5 \% \text {. Military rate abolished. Multiple rates } \\
\text { temporarily unified. Official rate is pegged to the US Dollar. } \\
\text { Parallel market premium oscillate in the } 10-75 \% \text { range. }\end{array}$ \\
\hline May 11, 1953-March 1959 & $\begin{array}{l}\text { De facto band around US } \\
\text { Dollar/Parallel Market }\end{array}$ & $\begin{array}{l}\text { Band width is }+/-5 \% \text {. Official rate is pegged to the US } \\
\text { Dollar. }\end{array}$ \\
\hline April 1959-August 27, 1971 & De facto band around US Dollar & $\begin{array}{l}\text { Band width is }+/-2 \% \text {. Premium in parallel market remained } \\
\text { in double digits through the spring of } 1960 \text {. Official rate is } \\
\text { pegged to the US Dollar. }\end{array}$ \\
\hline August 27, 1971-December 20, 1971 & Managed floating & \\
\hline December 20, 1971-February 12,1973 & Peg to US Dollar & \\
\hline February 12, 1973-November 1977 & $\begin{array}{l}\text { De facto moving band around US } \\
\text { Dollar }\end{array}$ & Band width is $+/-2 \%$. \\
\hline December 1977-December 2001 & Freely floating & \\
\hline
\end{tabular}

Reference currencies are the DM, the Euro, the Pound Sterling, and the US Dollar. 


\begin{tabular}{|c|c|c|}
\hline Date & $\begin{array}{l}\text { Classification: } \\
\text { Primary/Secondary/Tertiary }\end{array}$ & Comments \\
\hline November 1, 1927-September 21, 1931 & Peg & Gold Standard. Palestine Pound replaces Egyptian Piastre. \\
\hline September 21, 1931- July 1, 1950 & Peg to Pound Sterling & $\begin{array}{l}\text { Foreign exchange controls are introduced on September } \\
21,1939 \text {. }\end{array}$ \\
\hline July $1,1950-$ August 17,1971 & Peg to Pound Sterling & Dinar is introduced to replace Palestine Pound. \\
\hline August $17,1971-$ February 22,1975 & Peg to US Dollar & \\
\hline February $22,1975-$ September 1988 & Peg to SDR & \\
\hline October 1988-April 1989 & $\begin{array}{l}\text { Freely falling/De facto crawling band } \\
\text { around US Dollar }\end{array}$ & Band width $+/-5 \%$. \\
\hline May 1989-July 31, 1989 & De facto crawling band around US Dollar & $\begin{array}{l}\text { Band width }+/-5 \% \text {. Officially pegged to a basket of } \\
\text { currencies }\end{array}$ \\
\hline July $31,1989-$ February 17,1990 & $\begin{array}{l}\text { De facto crawling band around US } \\
\text { Dollar/Dual Market }\end{array}$ & Band width $+/-5 \%$. \\
\hline February 17, 1990-December 1992 & De facto crawling band around US Dollar & $\begin{array}{l}\text { Band width }+/-5 \% \text {. } \\
\text { Officially pegged to a basket of currencies }\end{array}$ \\
\hline March 1993-August 1995 & De facto crawling peg to US Dollar & $\begin{array}{l}\text { Except for the } 1988-1992 \text { period parallel premiums have } \\
\text { been nil. }\end{array}$ \\
\hline September 1995-December 2001 & De facto peg to US Dollar & \\
\hline
\end{tabular}

Notes: Reference currencies are the SDR, the Pound Sterling, and the US Dollar.

Kazakhstan

\begin{tabular}{|c|c|c|}
\hline Date & $\begin{array}{l}\text { Classification: } \\
\text { Primary/Secondary/Tertiary }\end{array}$ & Comments \\
\hline January 1991-June 1996 & $\begin{array}{l}\text { Freely falling/Freely floating/Multiple } \\
\text { exchange rates }\end{array}$ & $\begin{array}{l}\text { Ruble is the legal tender until November } 15,1993 \text { when } \\
\text { the tenge was issued as the national currency. } \\
\text { There is no price data before this date. }\end{array}$ \\
\hline June 1996-December 2001 & $\begin{array}{l}\text { De facto crawling band around US } \\
\text { Dollar }\end{array}$ & Band width is $+/-2 \%$. \\
\hline
\end{tabular}

Notes: Reference currency is the US Dollar.

Kenya

\begin{tabular}{|l|l|l|}
\hline Date & $\begin{array}{l}\text { Classification: } \\
\text { Primary/Secondary/Tertiary }\end{array}$ & Comments \\
\hline January 1, 1922-September 14, 1966 & $\begin{array}{l}\text { Currency Board/Union } \\
\text { Ped to }\end{array}$ & East African Shilling \\
\hline September 14, 1966-October 11, 1971 & Peg Pound Sterling & \\
\hline October 11, 1971-October 27, 1975 & Peg to US Dollar & \\
\hline October 27, 1975-December 1978 & Peg to SDR & $\begin{array}{l}\text { There are multiple exchange rates. De facto peg to the US } \\
\text { dollar until August 1981 -frequent devaluations versus } \\
\text { SDR afterwards. }\end{array}$ \\
\hline December, 1978- December 1986 & Peg to SDR & Officially pegged to a currency basket \\
\hline January 1987-September 1991 & Managed floating & $\begin{array}{l}\text { Officially pegged to a currency basket. Parallel market } \\
\text { premium peaked at 110\% on December 1992. }\end{array}$ \\
\hline October 1991-May 1994 & $\begin{array}{l}\text { Freely falling/Managed floating/Dual } \\
\text { There are multiple rates. }\end{array}$ \\
\hline May 1994-December 1995 & Managed floating & \\
\hline January 1996-December 2001 & Managed floating & \\
\hline
\end{tabular}

Notes: Tanzania and Uganda were part of this currency union. Reference currencies are the SDR, the Pound Sterling, and the US Dollar.

Kuwait

\begin{tabular}{|l|l|l|}
\hline Date & $\begin{array}{l}\text { Classification: } \\
\text { Primary/Secondary/Tertiary }\end{array}$ & Comments \\
\hline 1959-April 1, 1961 & Peg to Pound Sterling & Persian Gulf Rupee replaces Indian Rupee \\
\hline April 1, 1961-April 1969 & Dual Market/Currency board & $\begin{array}{l}\text { Dinar is introduced and replaces Persian Gulf Rupee. No } \\
\text { data on parallel market available. }\end{array}$ \\
\hline May 1969-June 24, 1972 & $\begin{array}{l}\text { De facto peg to US Dollar/Dual } \\
\text { Market }\end{array}$ & Parallel market premia is trivial. \\
\hline June 24, 1972-March 17, 1975 & Peg to US Dollar & Officially pegged to a basket of currencies \\
\hline March 17, 1975-April 19,1984 & De facto moving peg to US Dollar & $\begin{array}{l}\text { De facto moving peg to US } \\
\text { Dollar/Dual Market }\end{array}$ \\
\hline April 9, 1984-August 12,1984 & $\begin{array}{l}\text { De facto Moving Peg to the US } \\
\text { Dollar }\end{array}$ & Officially pegged to a basket of currencies,. \\
\hline August 12, 1984-December 2001 &
\end{tabular}

Notes: Reference currency is the US Dollar. 
Kyrgyz Republic

\begin{tabular}{|l|l|}
\hline Date & $\begin{array}{l}\text { Classification: } \\
\text { Primary/Secondary/Tertiary }\end{array}$ \\
\hline January, 1991-November 1999 & Freely falling/Managed floating \\
\hline December 1999-December 2001 & $\begin{array}{l}\text { De facto crawling band around US } \\
\text { Dollar }\end{array}$ \\
\hline
\end{tabular}

\section{Comments}

There is no price data before this date.

Band width is $+/-2 \%$.

${ }^{1}$ A twenty four-month window picks up the crawling band in late 1999 none is detected if the five-year window.

Notes: Reference currency is the US Dollar.

Lao

\begin{tabular}{|c|c|c|}
\hline Date & $\begin{array}{l}\text { Classification: } \\
\text { Primary/Secondary/Tertiary }\end{array}$ & Comments \\
\hline May 31, 1930-October 2, 1936 & Peg & Gold Standard \\
\hline October 2, 1936-December 1942 & Peg to French Franc & Abandonment of the Gold Standard \\
\hline September 9, 1939 & $\begin{array}{l}\text { Foreign Exchange Controls within } \\
\text { Franc-Zone framework }\end{array}$ & \\
\hline January 1943-December 1945 & Peg to Yen & \\
\hline December 1945-May 5, 1955 & Peg to French Franc/Parallel Market & \\
\hline May 5,1955 -October 10,1958 & Parallel Market & Kip replaces Indochina Piaster. There are multiple rates. \\
\hline October $10,1958-$ January 1,1962 & Peg to US Dollar & \\
\hline January 1, 1962-January 1, 1964 & Managed floating/Parallel Market & $\begin{array}{l}\text { The official rate is pegged and there are periodic } \\
\text { large devaluations. }\end{array}$ \\
\hline January 1, 1964-April 3, 1972 & $\begin{array}{l}\text { Crawling band around US } \\
\text { Dollar/Parallel Market }\end{array}$ & $\begin{array}{l}\text { There are multiple rates. There are two currencies after } \\
\text { March } 1969 .\end{array}$ \\
\hline April 3, 1972- March 28, 1973 & $\begin{array}{l}\text { Crawling band around US Dollar/ } \\
\text { Parallel Market }\end{array}$ & Band width is $+/-2 \%$. Temporary unification of rates. \\
\hline March 28, 1973-April 1988 & Managed floating/Parallel Market & There are multiple rates. \\
\hline May 1988-May 1990 & $\begin{array}{l}\text { Freely falling/Crawling band around } \\
\text { US Dollar/Dual Market }\end{array}$ & Band width is $+/-2 \%$. \\
\hline June 1990- September 31, 1995 & $\begin{array}{l}\text { Crawling band around US Dollar/Dual } \\
\text { Market }\end{array}$ & Band width is $+/-2 \%$. \\
\hline September 31, 1995-December 1996 & $\begin{array}{l}\text { Crawling band around US } \\
\text { Dollar/Parallel Market }\end{array}$ & $\begin{array}{l}\text { Band width is }+/-2 \% \text {. There was a short-lived unification } \\
\text { of the rates. }\end{array}$ \\
\hline January 1997-March, 2000 & $\begin{array}{l}\text { Freely Falling/Crawling band around } \\
\text { US Dollar/Dual Market }\end{array}$ & Band width is $+/-5 \%$. \\
\hline April 2000-December 2001 & Dual Market & $\begin{array}{l}\text { If a } 24-\text { month window is used a crawling }+/-2 \% \text { band is } \\
\text { detected for this period for the official rate. There is no }\end{array}$ \\
\hline
\end{tabular}

Notes: Reference currencies are the French Franc and the US Dollar. No data on parallel market is available.

Latvia

\begin{tabular}{|l|l|l|}
\hline Date & $\begin{array}{l}\text { Classification: } \\
\text { Primary/Secondary/Tertiary }\end{array}$ & Comments \\
\hline January, 1991-January 1994 & Freely falling/Managed floating & $\begin{array}{l}\text { There is no price data before this date. On July 20, 1992 } \\
\text { the Lativian Ruble replaced the Russian Ruble. On October } \\
\text { 19, 1993the Latvian lats became sole legal tender. }\end{array}$ \\
\hline February 1994-August 1994 & Peg to SDR/Freely falling & \\
\hline September 1994-December 2001 & Peg to SDR & \\
\hline
\end{tabular}

Notes: Reference currencies are the SDR and the US Dollar.

Lebanon

\begin{tabular}{|c|c|}
\hline Date & $\begin{array}{l}\text { Classification: } \\
\text { Primary/Secondary/Tertiary }\end{array}$ \\
\hline June 24,1928 -October 1,1936 & Peg \\
\hline October 1, 1936-February 1944 & Peg to French Franc \\
\hline February 1944-October 1946 & Peg to Pound Sterling \\
\hline October 1946-June 1950 & $\begin{array}{l}\text { De facto band around US Dollar/Dual } \\
\text { Market }\end{array}$ \\
\hline July $1950-$ August 1975 & $\begin{array}{l}\text { De facto band around US Dollar/Dual } \\
\text { Market }\end{array}$ \\
\hline September 1975-February 1984 & $\begin{array}{l}\text { De facto band around US Dollar/Dual } \\
\text { Market }\end{array}$ \\
\hline March 1984-July 1991 & Freely falling/Freely floating \\
\hline August 1991-February 1993 & De facto crawling peg to US Dollar \\
\hline March 1993-December 2001 & De facto peg to US Dollar \\
\hline
\end{tabular}

Notes: Reference currency is the US Dollar.

\section{Comments}

Gold Standard

Suspension of Gold standard

Band width $+/-5 \%$. The Lebanese Pound replaces the Lebanon-Syria Pound

Band width is $+/-2 \%$. Official rate is applied to some government transactions only.

Band width $+/-5 \%$.

On February 1, 1985 a second rate was used for the purpose of customs valuation of imports. 
Lesotho

\begin{tabular}{|l|l|l|}
\hline Date & $\begin{array}{l}\text { Classification: } \\
\text { Primary/Secondary/Tertiary }\end{array}$ & Comments \\
\hline 1910-January 22,1980 & $\begin{array}{l}\text { Exchange arrangement with no } \\
\text { separate legal tender }\end{array}$ & South African Pound—-then South african Rand. \\
\hline January 22, 1980-February 7, 1983 & $\begin{array}{l}\text { Peg to South African Rand/Dual } \\
\text { Market }\end{array}$ & The Loti is introduced. \\
\hline February 7, 1983-September 2, 1985 & Peg to South African Rand & No adjustments \\
\hline September 2, 1985-March 13, 1995 & $\begin{array}{l}\text { Peg to South African Rand/Dual } \\
\text { Market }\end{array}$ & \\
\hline March 13, 1995-December 2001 & Peg to South African Rand & No adjustments \\
\hline
\end{tabular}

Note: Lesotho is a member of the Southern Africa Customs Union, which also includes South Africa and Swaziland. Reference currency is the South African Rand.

Liberia

\begin{tabular}{|c|c|c|}
\hline Date & $\begin{array}{l}\text { Classification: } \\
\text { Primary/Secondary/Tertiary }\end{array}$ & Comments \\
\hline 1822-January 1, 1944 & $\begin{array}{l}\text { Exchange rate arrangement with no } \\
\text { separate legal tender }\end{array}$ & $\begin{array}{l}\text { The US Dollar and the Pound Sterling co-circulate as legal } \\
\text { tender. }\end{array}$ \\
\hline January 1, 1944-1988 & $\begin{array}{l}\text { Exchange rate arrangement with no } \\
\text { separate legal tender }\end{array}$ & $\begin{array}{l}\text { US Dollar, a limited number of coins circulate as well. } \\
\text { British currency ceased to be legal tender. }\end{array}$ \\
\hline 1988-October 30, 1997 & $\begin{array}{l}\text { Parallel Market/Multiple exchange } \\
\text { rates }\end{array}$ & $\begin{array}{l}\text { US Dollar, there are two notes issued the Liberty notes } \\
\text { introduced in } 1992 \text { and the JJ Roberts notes printed in } \\
1988-1992\end{array}$ \\
\hline October 30, 1997- August 31, 1998 & Peg to US Dollar & $\begin{array}{l}3,925 \% \text { devaluation in the official rate and a re-peg until } \\
\text { August. }\end{array}$ \\
\hline August 31, 1998-December 2001 & $\begin{array}{l}\text { De facto crawling peg to US Dollar } \\
\text { but it is not possible to fully classify ar } \\
\text { there is no inflation data and this } \\
\text { period is a strong candidate for freely } \\
\text { falling. }\end{array}$ & \\
\hline
\end{tabular}

Notes: Reference currency is the US Dollar. Price data is not available since 1991. 
Libyan Arab Republic

\begin{tabular}{|c|c|c|}
\hline Date & $\begin{array}{l}\text { Classification: } \\
\text { Primary/Secondary/Tertiary }\end{array}$ & Comments \\
\hline December 1927-1942 & Peg to US Dollar & $\begin{array}{l}\text { The French Franc and Pound Sterling also circulate. On } \\
\text { October 1, } 1930 \text { foreign exchange controls are introduced. }\end{array}$ \\
\hline 1942-March 24, 1952 & $\begin{array}{l}\text { Exchange rate arrangement with no } \\
\text { separate legal tender. }\end{array}$ & $\begin{array}{l}\text { The Algerian Francs, Egyptian Pound, and Military Lira } \\
\text { co-circulate. }\end{array}$ \\
\hline March 24, 1952- March 24, 1952 & Peg to Pound Sterling/Parallel Market & The Syrian pound is introduced. \\
\hline March 24, 1952-November 1955 & Managed floating & Check this vs. sterling \\
\hline December 1955-December 15,1971 & Peg to Pound Sterling/Dual Market & \\
\hline December 15, 1971-April 18, 1981 & Managed floating/Parallel Market & $\begin{array}{l}\text { Libya ceases to be a member of the Sterling Area. The } \\
\text { official rate is pegged to the US Dollar. }\end{array}$ \\
\hline April 18, 1981-March 18, 1986 & Managed floating/Parallel Market & \\
\hline March 18, 1986-May 1, 1986 & Managed floating/Parallel Market & $\begin{array}{l}\text { Band width is }+/-5 \% \text {. The Syrian Pound is Officially } \\
\text { pegged to the SDR. }\end{array}$ \\
\hline May 1, 1986-March 1992 & $\begin{array}{l}\text { De facto crawling band around US } \\
\text { Dollar/Parallel Market }\end{array}$ & $\begin{array}{l}\text { Band width is }+/-5 \% \text {. The official regime is a pre } \\
\text { announced band around a central SDR parity, width is }+/- \\
3.75 \%\end{array}$ \\
\hline March 1992-July 1992 & $\begin{array}{l}\text { De facto crawling band around US } \\
\text { Dollar/Parallel Market }\end{array}$ & $\begin{array}{l}\text { Band width is }+/-5 \% \text {. The official regime is a pre } \\
\text { announced band around a central SDR parity, width is }+/- \\
5.5 \%\end{array}$ \\
\hline July 1992-August 1992 & $\begin{array}{l}\text { De facto crawling band around US } \\
\text { Dollar/Parallel Market }\end{array}$ & $\begin{array}{l}\text { Band width is }+/-5 \% \text {. The official regime is a pre } \\
\text { announced band around a central SDR parity, width is } \\
+/-6.75 \% \text {. The parallel market premium is consistently } \\
\text { above } 400 \% \text {. }\end{array}$ \\
\hline August 1992-August 19, 1993 & $\begin{array}{l}\text { De facto crawling band around US } \\
\text { Dollar/Parallel Market }\end{array}$ & $\begin{array}{l}\text { Band width is }+/-5 \% \text {. The official regime is a pre } \\
\text { announced band around a central SDR parity, width is } \\
+/-8 \% \text {. The parallel market premium is consistently above } \\
400 \% \text {. }\end{array}$ \\
\hline August 19, 1993-November 1, 1994 & $\begin{array}{l}\text { De facto crawling band around US } \\
\text { Dollar/Parallel Market }\end{array}$ & $\begin{array}{l}\text { Band width is }+/-5 \% \text {. The official regime is a pre } \\
\text { announced band around a central SDR parity, width is } \\
+/-12.5 \% \text {. The parallel market premium is consistently } \\
\text { above } 400 \% \text {. }\end{array}$ \\
\hline November 1, 1994-October 31, 1998 & $\begin{array}{l}\text { De facto crawling band around US } \\
\text { Dollar/Parallel Market }\end{array}$ & $\begin{array}{l}\text { Band width is }+/-5 \% \text {. The official regime is a pre } \\
\text { announced band around a central SDR parity, width is }+/- \\
21.5 \% \text { The parallel market premium is consistently above } \\
400 \% \text {. }\end{array}$ \\
\hline October 31, 1998-February 14, 1999 & $\begin{array}{l}\text { De facto crawling band around US } \\
\text { Dollar/Parallel Market }\end{array}$ & $\begin{array}{l}\text { Band width is }+/-5 \% \text {. The official regime is a pre } \\
\text { announced band around a central SDR parity, width is } \\
+/-38.75 \% \text {. }\end{array}$ \\
\hline February 14, 1999-December 2001 & Dual Market & $\begin{array}{l}\text { Band width is }+/-5 \% \text {. The official regime is a pre } \\
\text { announced band around a central SDR parity, width is } \\
+/-38.75 \% \text {. The parallel market was legalized. }\end{array}$ \\
\hline
\end{tabular}

Notes: Reference currency is the US Dollar.

Lithuania

\begin{tabular}{|l|l|l|}
\hline Date & $\begin{array}{l}\text { Classification: } \\
\text { Primary/Secondary/Tertiary }\end{array}$ & Comments \\
\hline January 1991-April 1995 & Freely falling/Managed floating & On May 1, 1992 the Talonas was introduced as legal tender. \\
\hline May 1995-April 1, 1994 & De facto peg to US Dollar & \\
\hline April 1, 1994-December 2001 & Peg to US Dollar/Currency board & \\
\hline
\end{tabular}

Notes: Reference currency is the US Dollar.

Luxembourg

\begin{tabular}{|l|l|l|}
\hline Date & $\begin{array}{l}\text { Classification: } \\
\text { Primary/Secondary/Tertiary }\end{array}$ & Comments \\
\hline April 1, 1935-May 1940 & Peg to Belgian Franc & Capital controls are introduced \\
\hline May 1940-January 20, 1941 & Peg to Reichsmark & Capital controls intensified \\
\hline January 20, 1941-September 4, 1944 & $\begin{array}{l}\text { Exchange rate arrangement with no } \\
\text { separate legal tender }\end{array}$ & Reichsmark \\
\hline September 4, 1944-July 18, 1955 & Peg to US Dollar & \\
\hline July 18, 1955-March 5, 1990 & De facto peg to DM/Dual Market & Small parallel market premium. \\
\hline March 5, 1990-December 31, 1991 & De facto peg to DM & Euro \\
\hline January 1, 1999-December 2001 & Currency union & Prom
\end{tabular}

Notes: Specifics on the common margins (snake) agreement, EMS, etc. are available from the detailed chronologies. 
Macedonia

\begin{tabular}{|l|l|l|}
\hline Date & $\begin{array}{l}\text { Classification: } \\
\text { Primary/Secondary/Tertiary }\end{array}$ & Comments \\
\hline January 1993-December 1994 & Freely falling & There is no price data before this date. \\
\hline January 1995-January 1, 1999 & De facto crawling peg to DM & \\
\hline January 1, 1999-January 2000 & De facto crawling peg to Euro & \\
\hline February 2000-December 2001 & De facto band around Euro & Band width $+/-2 \%$. \\
\hline
\end{tabular}

Notes: Reference currencies are the US Dollar, the DM and the Euro.

Madagascar

\begin{tabular}{|l|l|l|}
\hline Date & $\begin{array}{l}\text { Classification: } \\
\text { Primary/Secondary/Tertiary }\end{array}$ & Comments \\
\hline January 12, 1900-June 6, 1925 & $\begin{array}{l}\text { Exchange rate arrangement with no } \\
\text { separate legal tender }\end{array}$ & French Franc \\
\hline June 6, 1925- February 8, 1944- & Peg to French Franc & $\begin{array}{l}\text { Only notes issued by Banque de Madagascar et des } \\
\text { Comores are sole legal tender. }\end{array}$ \\
\hline September 9, 1939 & $\begin{array}{l}\text { Exchange controls are introduced } \\
\text { within Franc zone }\end{array}$ & \\
\hline February 8, 1944- December 26, 1945 & Peg to US Dollar and Pound Sterling & On March 19, 1941 incorporated in the Sterling Area \\
\hline December 26, 1945-December 1946 & Peg to French Franc & Return to Franc Zone. CFA Franc is introduced. \\
\hline January 1947-December 1948 & Peg to French Franc/Freely falling & \\
\hline January 1949-July 1, 1963 & Peg to French Franc & Malagasy Franc is introduced. \\
\hline July 1, 1963-September 4,1971 & Peg to French Franc & Parallel market data is not available for this period. \\
\hline September 4, 1971-August 6,1973 & Dual Market & Band width is +/-2\%. \\
\hline August 6, 1971-April 2, 1982 & Peg to French Franc & $\begin{array}{l}\text { Officially pegged to a basket of currencies, frequent } \\
\text { adjustments }\end{array}$ \\
\hline April 2, 1982-June 1985 & Franc & $\begin{array}{l}\text { Despite the flexibility of the official rate, there is a parallel } \\
\text { market with premium in double digits. }\end{array}$ \\
\hline July 1985-April 1994 & Managed floating & See comment above. \\
\hline May 1994-October 1995 & Freely falling/Managed floating & \\
\hline November 1995-December 2001 & Freely floating & \\
\hline
\end{tabular}

Notes: Formerly Malagasy Republic. Reference currencies are the French Franc and US Dollar.

Malawi

\begin{tabular}{|l|l|l|}
\hline Date & $\begin{array}{l}\text { Classification: } \\
\text { Primary/Secondary/Tertiary }\end{array}$ & Comments \\
\hline $1891-1940$ & $\begin{array}{l}\text { Exchange arrangement with no } \\
\text { separate legal tender. }\end{array}$ & Pound Sterling \\
\hline 1940- April 1, 1956 & Peg to Pound Sterling/Currency Board & Southern Rhodesia Pound replaces British Pound \\
\hline April 1, 1956-November 16, 1964 & Peg to Pound Sterling/Parallel Market & $\begin{array}{l}\text { Rhodesia and Nyasaland Pound replace Southern Rodesia } \\
\text { Pound. }\end{array}$ \\
\hline November 16, 1964-February 15, 1971 & Peg to Pound Sterling/Parallel Market & $\begin{array}{l}\text { Malawi Pound is introduced replacing the Rhodesia and } \\
\text { Nyasaland Pound. }\end{array}$ \\
\hline February 15, 1971-November 19,1973 & Peg to Pound Sterling/Parallel Market & Kwacha is Introduced to replace Malawi pound. \\
\hline November 19, 1973-June 9, 1975 & Managed floating & $\begin{array}{l}\text { Official rate is pegged to a basket of undisclosed } \\
\text { currencies. }\end{array}$ \\
\hline June 9, 1975-January 17, 1984 & Managed floating & $\begin{array}{l}\text { Officially Pegged to SDR. Parallel premiums over 100\% in } \\
1977 \text { and again in 1982. }\end{array}$ \\
\hline January 17, 1984-January 1994 & Freely floating & Officially pegged to a basket of currencies \\
\hline February 1994-December 1994 & Freely falling/Freely floating & Since early 1996 parallel market premia is in single digits. \\
\hline January 1995-July 1997 & Peg to US Dollar/Freely falling & \\
\hline August 1997-August 1999 & Freely falling/Managed floating & \\
\hline September 1999-December 2001 & Managed floating & \\
\hline
\end{tabular}

Notes: Formerly Nyasaland. Reference currencies are the Pound sterling, the SDR and the US Dollar. 
Malaysia

\begin{tabular}{|c|c|c|}
\hline Date & $\begin{array}{l}\text { Classification: } \\
\text { Primary/Secondary/Tertiary }\end{array}$ & Comments \\
\hline June 25, 1903-February 1906 & Peg & Silver \\
\hline February $1906-$ February 15,1942 & Peg to Pound Sterling & $\begin{array}{l}\text { On September 18, } 1939 \text { foreign exchange controls are } \\
\text { introduced. }\end{array}$ \\
\hline February 15, 1942-September 2, 1945 & $\begin{array}{l}\text { Exchange rate arrangement with no } \\
\text { separate legal tender. }\end{array}$ & Japanese military Yen (Gumpyo) are declared legal tender. \\
\hline April 1, 1946-June 12, 1967 & Peg to Pound Sterling & The Straits Dollar became known as the Malayan Dollar. \\
\hline June $12,1967-$ September 5, 1975 & Peg to Pound Sterling & Malaysian Dollar, since renamed Ringgit, is introduced. \\
\hline September 5, 1975-July 1997 & $\begin{array}{l}\text { De facto moving band around US } \\
\text { Dollar }\end{array}$ & $\begin{array}{l}\text { Band is }+/-2 \% \text {. Officially the ringgit is pegged to a basket } \\
\text { of currencies }\end{array}$ \\
\hline August 1997-September 30, 1998 & Freely floating & \\
\hline September 30, 1998-December 2001 & Peg to US Dollar & \\
\hline \multicolumn{3}{|c|}{$\begin{array}{l}\text { Notes: Reference currencies are the Pound sterling and the US Dollar. } \\
\text { Mali } \\
\text { Central Bank of West African States are: Benin, Burkina Faso, Guinea-Bissau, Mali, Niger, Senegal, and Togo }{ }^{1}\end{array}$} \\
\hline Date & $\begin{array}{l}\text { Classification: } \\
\text { Primary/Secondary/Tertiary }\end{array}$ & Comments \\
\hline June 29, 1901- February 2, 1943 & Peg to French Franc & $\begin{array}{l}\text { Banque de l'Afrique Occidentale is allowed to issue bank } \\
\text { notes. Exchange controls are introduced in Franc zone on } \\
\text { September 9, 1939. }\end{array}$ \\
\hline February 2, 1943- December 26, 1945 & Peg to US Dollar and Pound Sterling & On December 1942 incorporated in the Sterling Area \\
\hline December 26. 1945-January 26, 1948 & Peg to French Franc/Currency union & Return to Franc Zone. The CFA Franc is introduced. \\
\hline January 26, 1948-September 20, 1949 & Dual Market & There is no parallel market data for this period. \\
\hline September 20, 1949-July 2, 1962 & Peg to French Franc/Currency union & \\
\hline July 2, 1962-February 1967 & Peg to US Dollar & $\begin{array}{l}\text { Mali Franc replaces CFA Franc with Mali Franc, } \\
\text { withdraws from Franc zone. }\end{array}$ \\
\hline February 1967-September 9, 1971 & Peg to French Franc/Currency union & \\
\hline September 9, 1971-March 21, 1974 & $\begin{array}{l}\text { De facto Peg to the French Franc/Dual } \\
\text { Market }\end{array}$ & Small parallel market premia. \\
\hline March 21, 1974-January 1, 1999 & Peg to French Franc & Mali joined WAMU on June 1, 1984. \\
\hline January 1, 1999-December 2001 & Peg to Euro & \\
\hline
\end{tabular}

Notes: reference currencies are the French franc and US Dollar.

Malta

\begin{tabular}{|c|c|c|}
\hline Date & $\begin{array}{l}\text { Classification: } \\
\text { Primary/Secondary/Tertiary }\end{array}$ & Comments \\
\hline June 16, 1915-July 1949 & $\begin{array}{l}\text { Exchange rate arrangement with no } \\
\text { separate legal tender }\end{array}$ & Pound Sterling \\
\hline July 1949-July 8, 1972 & Peg to Pound Sterling & $\begin{array}{l}\text { The Malta Pound (also known as Malta Lira) is introduced. } \\
\text { Pound sterling no longer legal tender. }\end{array}$ \\
\hline July 8, 1972-December 1977 & Moving band around Pound sterling & $\begin{array}{l}\text { Pound Sterling, narrow. Officially pegged to a basket of } \\
\text { currencies }\end{array}$ \\
\hline January 1978-January 1, 1999 & Moving band around DM & \\
\hline January 1, 1999-December 2001 & Moving band around Euro & \\
\hline \multicolumn{3}{|c|}{$\begin{array}{l}\text { Notes: reference currencies are the Pound Sterling, US Dollar, DM, and Euro. } \\
\text { Marshall Islands }\end{array}$} \\
\hline Date & $\begin{array}{l}\text { Classification: } \\
\text { Primary/Secondary/Tertiary }\end{array}$ & Comments \\
\hline $1885-1919$ & $\begin{array}{l}\text { Exchange rate arrangement with no } \\
\text { separate legal tender }\end{array}$ & German Mark \\
\hline $1919-1947$ & $\begin{array}{l}\text { Exchange rate arrangement with no } \\
\text { separate legal tender }\end{array}$ & Yen \\
\hline $1947-2001$ & $\begin{array}{l}\text { Exchange rate arrangement with no } \\
\text { separate legal tender }\end{array}$ & US Dollar \\
\hline
\end{tabular}


Mauritania

\begin{tabular}{|c|c|c|}
\hline Date & $\begin{array}{l}\text { Classification: } \\
\text { Primary/Secondary/Tertiary }\end{array}$ & Comments \\
\hline December 21,1851 & Peg to French Franc & Banque du Senegal began to issue bank notes. \\
\hline June 29,1901 & Peg to French Franc & $\begin{array}{l}\text { Banque de l'Afrique Occidentale is allowed to issue bank } \\
\text { notes. }\end{array}$ \\
\hline September 9, 1939 & $\begin{array}{l}\text { Exchange controls are introduced in } \\
\text { Franc zone }\end{array}$ & \\
\hline February 2, 1943- December 26, 1945 & Peg to US Dollar and Pound Sterling & On December 1942 incorporated in the Sterling Area \\
\hline December $26,1945-$ September 1,1973 & Peg to French Franc/Parallel Market & CFA Franc is introduced. \\
\hline September 1, 1971-June 29, 1973 & $\begin{array}{l}\text { De facto peg to French Franc/Dual } \\
\text { Market }\end{array}$ & Small parallel market premium. \\
\hline June 29, 1973-January 22, 1974 & Peg to French Franc/Parallel Market & The introduction of the Ouguiya unified the market. \\
\hline January 22, 1974-October 1983 & $\begin{array}{l}\text { De facto crawling band around US } \\
\text { Dollar/Parallel Market }\end{array}$ & $\begin{array}{l}\text { Band width }+/-2 \% \text {. Officially pegged to a basket of } \\
\text { currencies }\end{array}$ \\
\hline November 1983-October 18,1992 & $\begin{array}{l}\text { De facto crawling band around US } \\
\text { Dollar/Parallel Market }\end{array}$ & $\begin{array}{l}\text { Band width is }+/-5 \% \text {. Officially pegged to a basket of } \\
\text { currencies. Premia in parallel market reached } 257 \% \text { in } \\
\text { August } 1992 \text { - prior to the October devaluation. }\end{array}$ \\
\hline October 18, 1992-August 1994 & $\begin{array}{l}\text { De facto crawling peg to US } \\
\text { Dollar/Dual Market }\end{array}$ & \\
\hline September 1994-December 31, 1995 & $\begin{array}{l}\text { De facto crawling band around US } \\
\text { Dollar/Dual Market }\end{array}$ & $\begin{array}{l}\text { Band width }+/-2 \% \text {. Since May } 1995 \text { parallel market } \\
\text { premium is in single digits. }\end{array}$ \\
\hline December 31, 1995-December, 2001 & $\begin{array}{l}\text { De facto crawling band around US } \\
\text { Dollar }\end{array}$ & $\begin{array}{l}\text { Band width }+/-2 \% \text {. } \\
\text { Markets are unified. }\end{array}$ \\
\hline
\end{tabular}

I' During September 28, 1978-March 4, 1980, linked to the French Franc for banknote transactions.

Notes: Formerly Senegal. Reference currencies are the French Franc and US Dollar.

Mauritius

\begin{tabular}{|l|l|l|}
\hline Date & $\begin{array}{l}\text { Classification: } \\
\text { Primary/Secondary/Tertiary }\end{array}$ & Comments \\
\hline $1878-1934$ & $\begin{array}{l}\text { Exchange rate arrangement with no } \\
\text { separate legal tender }\end{array}$ & Indian Rupee \\
\hline 1934- November 21, 1967 & Peg to Pound Sterling/Currency board & The Mauritian Rupee was introduced. \\
\hline November 21, 1967-January 5, 1976 & Dual Markets & $\begin{array}{l}\text { Link to Pound Sterling is maintained. There is no data for } \\
\text { the free market rate for this period. }\end{array}$ \\
\hline January 5, 1976-May 1982 & $\begin{array}{l}\text { De facto crawling band around US } \\
\text { Dollar for official rate/Dual Market }\end{array}$ & $\begin{array}{l}\text { Officially pegged to SDR until February 28, 1983. Band } \\
\text { width is +/-2\%. Parallel market data begins in 1985. }\end{array}$ \\
\hline June 1982-January 1993 & $\begin{array}{l}\text { De facto crawling band around US } \\
\text { Dollar }\end{array}$ & $\begin{array}{l}\text { Band width is }+/-5 \% . \text { Officially pegged to a basket of } \\
\text { currencies }\end{array}$ \\
\hline November 1992-December 2001 & $\begin{array}{l}\text { De facto crawling band around US } \\
\text { Dollar }\end{array}$ & Band width is $+/-2 \%$ \\
\hline
\end{tabular}

Notes: Reference currencies are the Pound Sterling, the SDR and the US Dollar. 
Mexico

\begin{tabular}{|c|c|c|}
\hline Date & $\begin{array}{l}\text { Classification: } \\
\text { Primary/Secondary/Tertiary }\end{array}$ & Comments \\
\hline July 1933-May 1945 & Peg to US Dollar & Premium in parallel market is nil. \\
\hline May 1945-December 1946 & Peg to US Dollar/freely falling & $\begin{array}{l}\text { Premium in parallel market is nil until March 1976-by } \\
\text { August it had reached } 100 \% \text {. }\end{array}$ \\
\hline January 1947-September 1, 1976 & Peg to US Dollar & $\begin{array}{l}\text { Premium in parallel market is nil until March 1976- by } \\
\text { August it had reached } 100 \% \text {. }\end{array}$ \\
\hline September 1, 1976-February 1977 & Managed floating & \\
\hline March 1977-April 1981 & De facto peg to US Dollar & \\
\hline May 1981-January 1982 & De facto crawling peg to US Dollar & \\
\hline February 18, 1982-March 11988 & $\begin{array}{l}\text { Freely falling/Managed floating/Dual } \\
\text { Market }\end{array}$ & $\begin{array}{l}\text { The parallel market premia oscillates in the } 15-100 \% \\
\text { range. }\end{array}$ \\
\hline March 1, 1988-December 1988 & $\begin{array}{l}\text { Freely falling/Peg to US Dollar/Dual } \\
\text { Market }\end{array}$ & $\begin{array}{l}\text { Official rate is pegged during this period. Parallel market } \\
\text { premium has declined to low single digits. }\end{array}$ \\
\hline December 1988-November 11, 1991 & Crawling Peg/Dual Market & \\
\hline November 11, 1991-April 1992 & De facto crawling peg to US Dollar & $\begin{array}{l}\text { The rates were unified in November 1991. The official } \\
\text { arrangement was an ever widening crawling band (see } \\
\text { below). }\end{array}$ \\
\hline May 1992-January 1994 & De facto peg to US Dollar & $\begin{array}{l}\text { Officially three is a band. The annualized rate of crawl of } \\
\text { the upper limit of the band is } 2.4 \% \text { through October } 20 \text {, } \\
1992 \text { and } 4.7 \% \text { through June } 30,1993 \text {. }\end{array}$ \\
\hline February 1994-December 22, 1994 & $\begin{array}{l}\text { Pre announced crawling band around } \\
\text { US Dollar }\end{array}$ & Pre-announced band becomes binding \\
\hline December 22 1994-March 1996 & Freely falling/Freely floating & $\begin{array}{l}\text { In December } 1994 \text { the parallel market premia jumped to } \\
27 \% \text { from single digits. }\end{array}$ \\
\hline April 1996-December 2001 & Managed floating & \\
\hline
\end{tabular}

Notes: Reference currency is US Dollar.

Moldova

\begin{tabular}{|l|l|l|}
\hline Date & $\begin{array}{l}\text { Classification: } \\
\text { Primary/Secondary/Tertiary }\end{array}$ & Comments \\
\hline January 1991-February 1995 & Multiple Rates/Freely falling & $\begin{array}{l}\text { There is no price data before this date. On November 29, } \\
1993 \text { the Leu replaces the Ruble. }\end{array}$ \\
\hline March 1995-May 1998 & De facto Peg & \\
\hline June 1998-February 2000 & Freely falling/Managed floating & \\
\hline March 2000-December 2001 & De facto peg & \\
\hline
\end{tabular}

Notes: Reference currency is US Dollar.

Micronesia, Federated States

\begin{tabular}{|l|l|l|}
\hline Date & $\begin{array}{l}\text { Classification: } \\
\text { Primary/Secondary/Tertiary }\end{array}$ & Comments \\
\hline January 1991-February 1995 & Multiple Rates/Freely falling & $\begin{array}{l}\text { There is no price data before this date. On November 29, } \\
1993 \text { the Leu replaces the Ruble. }\end{array}$ \\
\hline March 1995-May 1998 & De facto Peg & \\
\hline June 1998-February 2000 & Freely falling/Managed floating & \\
\hline March 2000-December 2001 & De facto peg & \\
\hline
\end{tabular}

Notes: Reference currency is US Dollar.

Mongolia

\begin{tabular}{|l|l|l|}
\hline Date & $\begin{array}{l}\text { Classification: } \\
\text { Primary/Secondary/Tertiary }\end{array}$ & Comments \\
\hline February 1991-May 27, 1993 & Freely floating/Dual Market & There is no price data before this date \\
\hline May 27. 1993-August 1997 & Freely falling/Managed floating & \\
\hline September 1997-November 2001 & $\begin{array}{l}\text { De facto crawling band around the US } \\
\text { Dollar }\end{array}$ & $\begin{array}{l}\text { Band width is +/-2\%. The Mongolian Tugrik was renamed } \\
\text { Togrog on December 14, 1998. }\end{array}$ \\
\hline
\end{tabular}

Notes: Reference currency is US Dollar.

Monaco

\begin{tabular}{|l|l|l|}
\hline Date & $\begin{array}{l}\text { Classification: } \\
\text { Primary/Secondary/Tertiary }\end{array}$ & Comments \\
\hline 1925 -December 2001 & $\begin{array}{l}\text { Exchange rate arrangement with no } \\
\text { separate legal tender }\end{array}$ & French Franc \\
\hline
\end{tabular}




Morocco
\begin{tabular}{|l|l|l|}
\hline Date & $\begin{array}{l}\text { Classification: } \\
\text { Primary/Secondary/Tertiary }\end{array}$ & Comments \\
\hline December 30,1924-1939 & Peg to French Franc & Capital controls are introduced in Franc-Zone \\
\hline November 1942-December 6, 1944 & Peg to Pound Sterling and US Dollar & \\
\hline December 6, 1944-December 1944 & Peg to French Franc & Return to Franc Zone. \\
\hline January 1945-December 1948 & Peg to French Franc/Freely falling & \\
\hline January 1949-October 17, 1959 & Peg to French Franc & \\
\hline October 17, 1959-May 17, 1973 & Peg to French Franc & The Dirham replaced the Moroccan Franc \\
\hline May 17, 1973-December 1985 & Moving band around French Franc & $\begin{array}{l}\text { Band width is +/-2\%. Officially pegged to a basket of } \\
\text { currencies. Dual rates, parallel market premia is trivial. }\end{array}$ \\
\hline January 1986-January 1, 1999 & $\begin{array}{l}\text { Moving band around } \\
\text { French Franc }\end{array}$ & $\begin{array}{l}\text { Band width is +/-2\%. Officially pegged to a basket of } \\
\text { currencies. }\end{array}$ \\
\hline January 1, 1999-December 2001 & $\begin{array}{l}\text { Moving band around } \\
\text { Euro }\end{array}$ & $\begin{array}{l}\text { Band width is +/-2\%. Officially pegged to a basket of } \\
\text { currencies. }\end{array}$ \\
\hline
\end{tabular}

Notes. The reference currencies are the French Franc, the US Dollar, and the Euro.

Myanmar

\begin{tabular}{|c|c|c|}
\hline Date & $\begin{array}{l}\text { Classification: } \\
\text { Primary/Secondary/Tertiary }\end{array}$ & Comments \\
\hline April 1, 1937-1943 & Peg to Pound Sterling & $\begin{array}{l}\text { Burmese Rupee is introduced. Indian Rupee is no longer } \\
\text { legal tender after } 1939 .\end{array}$ \\
\hline $1943-1945$ & Peg to Yen & \\
\hline 1945-July,1952 & Peg to Pound Sterling & \\
\hline July 1952-July 1972 & Peg to Pound Sterling & Kyat replaces Burmese Rupee \\
\hline August 1972-July 1, 1974 & Peg to Pound Sterling/Freely falling & $\begin{array}{l}\text { There are multiple rates. These are taxes on the purchases } \\
\text { of Sterling and US Dollar. }\end{array}$ \\
\hline July 1, 1974-January 25, 1975 & $\begin{array}{l}\text { Freely falling/Managed } \\
\text { floating/Parallel Market }\end{array}$ & \\
\hline January 25, 1975-February 1976 & $\begin{array}{l}\text { Freely Falling/ Moving band around } \\
\text { US Dollar/Parallel market }\end{array}$ & The official rate for the Kyat is linked to the SDR. \\
\hline March 1976-April 1983 & $\begin{array}{l}\text { Moving band around US } \\
\text { Dollar/Parallel market }\end{array}$ & Band width is $+/-5 \%$. \\
\hline May 1983-March 1986 & Managed floating/Parallel market & $\begin{array}{l}\text { The official rate is pegged to the SDR. Parallel market } \\
\text { premium oscillates in the } 20-35 \% \text { range. }\end{array}$ \\
\hline April 1986-March 1988 & $\begin{array}{l}\text { Moving band around US } \\
\text { Dollar/Parallel market }\end{array}$ & $\begin{array}{l}\text { The official rate is pegged to the SDR. There is break in } \\
\text { the data for the parallel rate from April } 1987 \text { to December } \\
1988 \text {. }\end{array}$ \\
\hline April 1988-May 1991 & $\begin{array}{l}\text { Freely falling/Moving band around US } \\
\text { Dollar/Parallel market }\end{array}$ & $\begin{array}{l}\text { Band width is }+/-5 \% \text {. Parallel market premia double } \\
\text { during this period from about } 45 \% \text { to } 90 \% \text {. Although the } \\
\text { official rate fas not be devalued versus the SDR since } 1977 \\
\text { there are periodic bouts of inflation. }\end{array}$ \\
\hline June 1991-December 1992 & $\begin{array}{l}\text { Moving band around US } \\
\text { Dollar/Parallel market }\end{array}$ & Band width is $+/-5 \%$. Official rate is pegged to the SDR \\
\hline January 1993-January, 1994 & $\begin{array}{l}\text { Freely falling/Moving band around US } \\
\text { Dollar/Parallel market }\end{array}$ & Band width is $+/-5 \%$. \\
\hline February 1994-July 1996 & $\begin{array}{l}\text { De facto moving band around US } \\
\text { Dollar/Parallel market }\end{array}$ & Band width is $+/-5 \%$. Official rate is pegged to the SDR. \\
\hline August 1996-January 1999 & $\begin{array}{l}\text { Freely falling/De facto moving band } \\
\text { around US Dollar/Dual Market }\end{array}$ & $\begin{array}{l}\text { The official rate remains pegged to the SDR. } \\
\text { Parallel market premia is consistently above } 100 \% \text { and } \\
\text { reached } 294 \% \text { in July } 1997 \text {. An unofficial parallel market } \\
\text { also exits. }\end{array}$ \\
\hline February 1999-December 2001 & Dual Market & $\begin{array}{l}\text { There is no data for the period for the parallel rate. } \\
\text { Officially pegged to the SDR. An unofficial parallel market } \\
\text { also exits. }\end{array}$ \\
\hline
\end{tabular}

Notes: Formerly Burma. Reference currencies are US Dollar and SDR. 


\begin{tabular}{|c|c|c|}
\hline \multicolumn{3}{|l|}{ Nepal } \\
\hline Date & $\begin{array}{l}\text { Classification: } \\
\text { Primary/Secondary/Tertiary }\end{array}$ & Comments \\
\hline $19^{\text {th }}$ century-1945 & $\begin{array}{l}\text { Exchange rate arrangement with no } \\
\text { separate legal tender. }\end{array}$ & Indian Rupee \\
\hline 1945-August 1958 & Managed floating & $\begin{array}{l}\text { First issuance of the Nepalese Rupee. Indian Rupee is also } \\
\text { accepted as legal tender. }\end{array}$ \\
\hline August 1958-October 17, 1966 & Peg to Indian Rupee & \\
\hline October 17, 1966-December 1973 & Peg to Indian Rupee & Indian Rupee is no longer accepted as legal tender. \\
\hline January 1974-March 30, 1978 & Peg to Indian Rupee & There are multiple rates. \\
\hline March 30, 1978-September 19, 1981 & $\begin{array}{l}\text { De facto crawling band around US } \\
\text { Dollar/Dual Market }\end{array}$ & $\begin{array}{l}\text { Band width is }+/-5 \% \text {. There are multiple rates. An official } \\
\text { rate is pegged to the US Dollar. }\end{array}$ \\
\hline September 19, 1981-March 4, 1992 & $\begin{array}{l}\text { De facto crawling band } \\
\text { Around US Dollar }\end{array}$ & Band width is $+/-2 \%$ \\
\hline March 4, 1992-February 12, 1993 & $\begin{array}{l}\text { De facto crawling band around US } \\
\text { Dollar/Dual Market }\end{array}$ & $\begin{array}{l}\text { Band width is }+/-5 \% \text {. An official rate is pegged to the US } \\
\text { Dollar November } 1992 \text {. }\end{array}$ \\
\hline February 12, 1993-June 1995 & Peg to US Dollar & $\begin{array}{l}\text { While the official rate is pegged, parallel market premia } \\
\text { oscillate in the } 10-20 \% \text { range. }\end{array}$ \\
\hline July 1995-December 2001 & $\begin{array}{l}\text { De facto crawling band } \\
\text { around US Dollar }\end{array}$ & $\begin{array}{l}\text { Band width is }+/-2 \% \text {. There are sub periods where the } \\
\text { exchange rate is pegged interspersed with moderate } \\
\text { devaluations. Since September } 1997 \text { parallel market premia } \\
\text { have remained in single digits. }\end{array}$ \\
\hline
\end{tabular}

Notes: Reference currencies are the US Dollar and Indian Rupee.

Netherlands

\begin{tabular}{|c|c|c|}
\hline Date & $\begin{array}{l}\text { Classification: } \\
\text { Primary/Secondary/Tertiary }\end{array}$ & Comments \\
\hline May $10,1940-$ September 14,1944 & Peg to Reichsmark & \\
\hline September 14,1944 -August 1950 & Managed floating/Parallel market & $\begin{array}{l}\text { The official rate is pegged to the US Dollar. Parallel } \\
\text { market premium peaks at } 154 \% \text { on November } 1946 \text { and } \\
\text { remains in double digits through early } 1952 \text {. }\end{array}$ \\
\hline September 1950-November 1952 & De facto band around US Dollar & Band width is $+/-2 \%$. \\
\hline December 1952-May 9, 1971 & Peg to US Dollar & \\
\hline May 9, 1971-May 1974 & De facto crawling band around DM & Band width is $+/-2 \%$. \\
\hline June 1974-February 1983 & De facto crawling peg around DM & \\
\hline March 1983-January 1, 1999 & De facto peg around DM & $\begin{array}{l}\text { One currency crash versus the dollar on March 1991, none } \\
\text { versus the DM. }\end{array}$ \\
\hline January 1, 1999-December 2001 & Currency union & Euro \\
\hline
\end{tabular}

Notes: Specifics on the common margins (snake) agreement, EMS, etc. are available from the detailed chronologies.

Notes: Reference currencies are the US Dollar, the DM, and the Euro.

New Zealand

\begin{tabular}{|l|l|l|}
\hline Date & $\begin{array}{l}\text { Classification: } \\
\text { Primary/Secondary/Tertiary }\end{array}$ & Comments \\
\hline September 21,1931-July 10,1967 & Peg to Pound Sterling & $\begin{array}{l}\text { Adherence to Sterling Area, On December 1938 foreign } \\
\text { exchange controls were introduced. Parallel market premia } \\
\text { is trivial since the data was collected beginning in 1947. }\end{array}$ \\
\hline July 10, 1967-December 23,1971 & Peg to Pound Sterling & New Zealand Dollar replaces New Zealand Pound \\
\hline December 23,1971-July 9, 1973 & Peg to US Dollar & $\begin{array}{l}\text { Parallel market premia never exceeded 4\% right after } \\
\text { WWII and has been nil since. }\end{array}$ \\
\hline July 9, 1973- March 4, 1985 & $\begin{array}{l}\text { De facto moving band around } \\
\text { Australian Dollar }\end{array}$ & Band width is $+/-2 \%$. \\
\hline March 4, 1985-December 2001 & Managed floating & \\
\hline
\end{tabular}

Notes: Reference currencies are the US Dollar, the Australian Dollar, and the Pound Sterling. 


\begin{tabular}{|c|c|c|}
\hline \multicolumn{3}{|l|}{ Nicaragua } \\
\hline Date & $\begin{array}{l}\text { Classification: } \\
\text { Primary/Secondary/Tertiary }\end{array}$ & Comments \\
\hline January $1931-$ October 20,1950 & Peg to US Dollar & \\
\hline October 20, 1950-March 1, 1963 & $\begin{array}{l}\text { De facto band around US Dollar/Dual } \\
\text { Market }\end{array}$ & There are multiple rates. Band width is $+/-5 \%$. \\
\hline March 1, 1963-December 1969 & Peg to US Dollar & \\
\hline January $1970-$ November 16,1974 & $\begin{array}{l}\text { De facto band around US } \\
\text { Dollar/Parallel market }\end{array}$ & There are multiple rates. Band width is $+/-2 \%$. \\
\hline November $16,1974-$ September 8,1978 & Peg to US Dollar & \\
\hline September 8, 1978-April 6, 1979 & $\begin{array}{l}\text { De facto band around US Dollar /Dual } \\
\text { Market }\end{array}$ & Band width is $+/-2 \%$. \\
\hline April 6, 1979-August 1982 & Freely floating/Dual Market & $\begin{array}{l}\text { There are multiple rates. The parallel market premium } \\
\text { oscillates between } 20-300 \% \text {. }\end{array}$ \\
\hline September 1982-April 30, 1991 & $\begin{array}{l}\text { Freely falling/Freely floating/Dual } \\
\text { Markets }\end{array}$ & $\begin{array}{l}\text { There are multiple rates. The period from June } 1986-\text { July } \\
1987 \text { registers as a "hyperfloat." On November } 1987 \text { the } \\
\text { parallel premium hit its historic high of } 11,329 \% \text {. On } \\
\text { February } 15,1988 \text { the new Cordoba replaced the old } \\
\text { Cordoba. Inflation peaks at } 63,776 \% \text {. }\end{array}$ \\
\hline April 30, 1991-February 1992 & Peg to US Dollar/Freely falling & $\begin{array}{l}\text { In the early stages of the peg inflation was as high as } \\
24,293 \% \text {. }\end{array}$ \\
\hline March 1992-December 1992 & Peg to US Dollar & \\
\hline January 1993-December 2001 & Crawling peg to US Dollar & $\begin{array}{l}\text { Since 1995, the parallel market premia has all but } \\
\text { disappeared. }\end{array}$ \\
\hline
\end{tabular}

Notes: Reference currency is the US Dollar.

Niger

Central Bank of West African States: Benin, Burkina Faso, Cote D'Ivoire, Guinea-Bissau, Mali, Niger, Senegal, and Togo ${ }^{1}$

\begin{tabular}{|l|l|l|}
\hline Date & $\begin{array}{l}\text { Classification: } \\
\text { Primary/Secondary/Tertiary }\end{array}$ & Comments \\
\hline June 29, 1901- February 2,1943 & Peg to French Franc & $\begin{array}{l}\text { Banque de 1'Afrique Occidentale is allowed to issue bank } \\
\text { notes. Exchange controls are introduced in Franc zone on } \\
\text { September 9, 1939. }\end{array}$ \\
\hline February 2, 1943- December 26. 1945 & Peg to US Dollar and Pound Sterling & On December 1942 incorporated in the Sterling Area \\
\hline December 26. 1945- May 12, 1962 & Peg to French Franc & Return to Franc Zone. The CFA Franc is introduced. \\
\hline September 20, 1949- & Peg to French Franc & Creation of the Central Bank of West African States \\
\hline May 12, 1962-September 9, 1971 & Peg to French Franc & Low parallel premium. \\
\hline September 9, 1971-March 21, 1974 & $\begin{array}{l}\text { De facto peg to French Franc/Dual } \\
\text { Market }\end{array}$ & \\
\hline March 21, 1974- & Peg to French Franc & One 100\% devaluation. \\
\hline January 1994-January 1995 & Peg to French Franc/Freely falling & \\
\hline January 1995-January 1, 1999 & Peg to French Franc & \\
\hline January 1, 1999-December 2001 & Peg to Euro &
\end{tabular}

${ }^{1}$ Mali joined the currency arrangement at a later date.

Note: Reference currencies are the French Franc and the Euro 
Nigeria

\begin{tabular}{|c|c|c|}
\hline Date & $\begin{array}{l}\text { Classification: } \\
\text { Primary/Secondary/Tertiary }\end{array}$ & Comments \\
\hline 1916-July 1, 1959 & Peg to Pound Sterling/Currency board & West Africa Pound is introduced. \\
\hline July $1,1959-$ August 23,1971 & Peg to Pound Sterling & Nigerian Pound is issued to replace West Africa Pound. \\
\hline August 23, 1971-November 1, 1971 & Managed floating/Dual Market & The official rate is pegged to the Pound. \\
\hline November 1, 1971-January 1, 1973 & Managed floating/Parallel market & $\begin{array}{l}\text { The link to the Pound is severed and the official rate is now } \\
\text { pegged to the US Dollar. The official dual market was } \\
\text { abolished but an active parallel market continued. }\end{array}$ \\
\hline January 1, 1973-April 1, 1974 & Managed floating/Parallel market & $\begin{array}{l}\text { The Naira replaces the Nigerian Pound. The link to the US } \\
\text { Dollar for the official rate is discontinued and the official } \\
\text { rate is a pegged to the a basket of currencies. Parallel } \\
\text { market premia are in the } 30-100 \% \text { range. }\end{array}$ \\
\hline April 1, 1974-February 1983 & Managed floating & The Naira is officially pegged to a basket of currencies \\
\hline April 1983-September 1984 & $\begin{array}{l}\text { Freely falling/Managed } \\
\text { floating/Parallel market }\end{array}$ & $\begin{array}{l}\text { From August } 1983 \text { to May 1984, the official rate is pegged } \\
\text { to the US Dollar. On December } 1983 \text { the parallel market } \\
\text { premium reached } 457 \% \text {. }\end{array}$ \\
\hline September 29, 1985-January 1987 & Managed floating/Dual Market & $\begin{array}{l}\text { The official rate applied to only some government } \\
\text { transactions. }\end{array}$ \\
\hline February 1987-December, 1989 & $\begin{array}{l}\text { Freely floating/Freely falling/Dual } \\
\text { Market }\end{array}$ & \\
\hline January 1990-May 1991 & Managed floating/Dual Market & \\
\hline June 1991-March 1996 & $\begin{array}{l}\text { Freely falling/Managed floating//Dual } \\
\text { Market }\end{array}$ & The official rate is pegged to the US Dollar. \\
\hline April 1996-December 2001 & Managed floating/Dual Market & $\begin{array}{l}\text { Through December } 1998 \text {, the official rate is pegged to the } \\
\text { US Dollar. The parallel market premium is consistently } \\
\text { above } 250 \% \text { through December } 1998 \text {. On January } 1999 \text { the } \\
\text { Naira was devalued by } 291 \% \text {. }\end{array}$ \\
\hline
\end{tabular}

Notes: Reference currencies are the US Dollar and the Pound Sterling.

Norway

\begin{tabular}{|c|c|c|}
\hline Date & $\begin{array}{l}\text { Classification: } \\
\text { Primary/Secondary/Tertiary }\end{array}$ & Comments \\
\hline September 28, 1931-August 29, 1939 & Peg to Pound Sterling & Suspension of gold standard, joined the Sterling Area. \\
\hline April 1940-May 16, 1945 & Peg to Reichsmark & \\
\hline May 16, 1945-March 1954 & $\begin{array}{l}\text { De facto band around US } \\
\text { Dollar/Parallel market }\end{array}$ & $\begin{array}{l}\text { Band width is }+/-5 \% \text {. The official rate is pegged to the US } \\
\text { Dollar. Parallel market premium climbs to } 86 \% \text { on } \\
\text { December } 1948 \text {. }\end{array}$ \\
\hline April 1954-April 1956 & $\begin{array}{l}\text { De facto band around US } \\
\text { Dollar/Parallel market }\end{array}$ & $\begin{array}{l}\text { Band width is }+/-2 \% \text {. Substantially lower premium in the } \\
\text { parallel market in this period - the peak is } 13 \% \text {. }\end{array}$ \\
\hline May $1956-1967$ & Peg to US Dollar & \\
\hline 1967-March 19, 1973 & Peg to US Dollar & A second rate - the Investment Dollar Krone is introduced. \\
\hline March 19, 1973-June 1982 & Moving band around DM & Band width is $+/-2 \%$. \\
\hline July $1982-$ June 1987 & Managed floating & Officially pegged to a basket of currencies \\
\hline July 1987-December 10, 1992 & Moving band around DM & $\begin{array}{l}\text { Band width is }+/-2 \% \text {. December } 1992 \text { does not register as } \\
\text { a currency crash. }\end{array}$ \\
\hline December 10, 1992-December 2001 & Managed floating & \\
\hline
\end{tabular}

Notes: Specifics on the common margins (snake) agreement, EMS, etc. are available from the detailed chronologies. Reference currencies are the US Dollar, the DM, and the Euro. 
Pakistan

\begin{tabular}{|c|c|c|}
\hline Date & $\begin{array}{l}\text { Classification: } \\
\text { Primary/Secondary/Tertiary }\end{array}$ & Comments \\
\hline April 1, 1948-January 15, 1959 & Peg to Pound Sterling & $\begin{array}{l}\text { Pakistan Rupee is introduced. On June } 1954 \text { premium in } \\
\text { parallel market reached } 103 \% \text {. }\end{array}$ \\
\hline January $15,1959-$ September 17,1971 & Multiple rates/Parallel Market & The Rupee is linked to the Pound Sterling \\
\hline September 17, 1971-January 8, 1982 & Peg to US Dollar/Parallel Market & $\begin{array}{l}\text { In December } 1971 \text { the parallel market premium peaks at } \\
212 \% \text {. }\end{array}$ \\
\hline January 8, 1982-January 1984 & $\begin{array}{l}\text { De facto crawling peg to the US } \\
\text { Dollar/Parallel Market }\end{array}$ & \\
\hline February 1984-August 1989 & $\begin{array}{l}\text { De facto crawling band around the US } \\
\text { Dollar/Parallel Market }\end{array}$ & $\begin{array}{l}\text { Band width is }+/-2 \% \text {. If the parallel rate is used the band } \\
\text { width is }+/-\% 5 \% \text {. }\end{array}$ \\
\hline September 1989-April 1991 & De facto crawling peg/Parallel Market & \\
\hline May 1991-April 1994 & $\begin{array}{l}\text { De facto crawling band around the US } \\
\text { Dollar/Parallel Market }\end{array}$ & $\begin{array}{l}\text { Band width is }+/-2 \% \text {. If the parallel rate is used the band } \\
\text { width is }+/-\% 5 \% \text {. From August } 1993 \text { through May } 1998 \\
\text { the parallel market premium is in single digits. }\end{array}$ \\
\hline May 1994-July 22, 1998 & De facto crawling peg/Parallel Market & $\begin{array}{l}\text { A more precise description of the post-November } 1996 \\
\text { period is mini pegs lasting a few moths interspersed with a } \\
\text { regular devaluation. }\end{array}$ \\
\hline July 22, 1998-May 19, 1999 & De facto crawling band/Dual Market & $\begin{array}{l}\text { Band width is }+/-2 \% \text { (on the basis of the parallel market } \\
\text { rate). There are multiple rates. }\end{array}$ \\
\hline May $19,1999-$ August 2000 & De facto crawling peg/Parallel Market & \\
\hline September 2000-December 2001 & De facto crawling band/Parallel Market & Band width is $+/-2 \%$. \\
\hline
\end{tabular}

Notes: Reference currency is the US Dollar.

Panama

\begin{tabular}{|l|}
\hline Date \\
\hline June 27, 1904-December, 2001 \\
\hline
\end{tabular}

Notes: Reference currency is the US Dollar.

Paraguay

\begin{tabular}{|c|c|c|}
\hline Date & $\begin{array}{l}\text { Classification: } \\
\text { Primary/Secondary/Tertiary }\end{array}$ & Comments \\
\hline 1903-March 1923 & Peg to Argentine Gold Peso & \\
\hline March 1923-October 5, 1943 & Peg to Argentine Paper Peso & \\
\hline October 5, 1943-December 18, 1946 & Peg to Argentine Paper Peso & Guarani replaces Paraguayan Peso \\
\hline December 18, 1946-November 5, 1949 & Peg to US Dollar & \\
\hline November 5, 1949-August 12, 1957 & De facto band around US Dollar & $\begin{array}{l}\text { Band width is }+/-5 \% \text {. There are multiple exchange rates. In } \\
\text { September } 1951 \text { the parallel premium rose to } 500 \% \text {. }\end{array}$ \\
\hline August $12,1957-$ October 1960 & $\begin{array}{l}\text { De facto peg to the US Dollar/Dual } \\
\text { Market }\end{array}$ & Parallel market premium in single digits during this period. \\
\hline October 1960-July 23, 1973 & $\begin{array}{l}\text { De facto band around US } \\
\text { Dollar/Parallel Market }\end{array}$ & $\begin{array}{l}\text { Band width is }+/-2 \% \text {. The official rate is pegged to US } \\
\text { Dollar. }\end{array}$ \\
\hline July 23, 1973-August 1981 & $\begin{array}{l}\text { De facto band around US } \\
\text { Dollar/Parallel Market }\end{array}$ & Band width is $+/-5 \%$. There are multiple exchange rates. \\
\hline September 1981-March 1985 & Managed floating/Parallel market & $\begin{array}{l}\text { Official rate is still pegged to the US Dollar. Parallel } \\
\text { market premia begins its ascent in late } 1982 \text { and reaches } \\
257 \% \text { ion October } 1983 \text {. }\end{array}$ \\
\hline April 1985-April 1986 & $\begin{array}{l}\text { Freely falling/Freely floating/Parallel } \\
\text { market }\end{array}$ & There are multiple exchange rates. \\
\hline May 1986-February 27, 1989 & $\begin{array}{l}\text { De facto crawling band around US } \\
\text { Dollar/Parallel market }\end{array}$ & $\begin{array}{l}\text { There are multiple exchange rates. Band width is }+/-5 \% \text {. } \\
\text { The peg of the official rate to the US Dollar is terminated. }\end{array}$ \\
\hline February 27, 1989-January 1991 & $\begin{array}{l}\text { Freely falling/De facto crawling band } \\
\text { around US Dollar }\end{array}$ & $\begin{array}{l}\text { Unification and float. Band width is }+/-5 \% \text {. Despite } \\
\text { unification parallel market premia do not decline into } \\
\text { single digits until March } 1996 .\end{array}$ \\
\hline February 1991-June 1999 & De facto crawling peg to US Dollar & \\
\hline July 1999-December 2001 & $\begin{array}{l}\text { De facto crawling band around US } \\
\text { Dollar }\end{array}$ & Band width is $+/-5 \%$, PPP rule \\
\hline
\end{tabular}

Notes: Reference currency is the US Dollar.

\section{Classification:}

Primary/Secondary/Tertiary

Exchange rate arrangement with no separate legal tender

\section{Comments}

US Dollar

US Dollar

Pakistan Rupee is introduced. On June 1954 premium in treached $103 \%$

In December 1971 the parallel market premium peaks at $212 \%$.

Band width is $+/-2 \%$. If the parallel rate is used the band

Band width is $+/-2 \%$. If the parallel rate is used the band the parallel market premium is in single digits.

period is mini pegs lasting a few moths interspersed with regular devaluation.

Band width is $+/-2 \%$. 
Peru

\begin{tabular}{|c|c|c|}
\hline Date & $\begin{array}{l}\text { Classification: } \\
\text { Primary/Secondary/Tertiary }\end{array}$ & Comments \\
\hline February $1930-$ October 1946 & Peg to US Dollar & \\
\hline November 1946-September 7, 1948 & Peg to US Dollar/Freely falling & \\
\hline September 7, 1948-May 1959 & $\begin{array}{l}\text { De facto crawling band around US } \\
\text { Dollar }\end{array}$ & $\begin{array}{l}\text { Band width is }+/-5 \% \text {. There are multiple exchange rates. } \\
\text { An official rate is pegged to the US Dollar. }\end{array}$ \\
\hline May 1959-May 17,1960 & Peg to US Dollar & There are multiple exchange rates. \\
\hline May $17,1960-$ October 5, 1967 & Peg to US Dollar & \\
\hline October 5, 1967-June 1971 & $\begin{array}{l}\text { De facto band around US Dollar/Dual } \\
\text { Market }\end{array}$ & $\begin{array}{l}\text { Band width is }+/-5 \% \text {. On May } 16,1970 \text { capital controls } \\
\text { are reintroduced. An official rate is pegged to the US } \\
\text { Dollar. }\end{array}$ \\
\hline July 1971-August 1975 & Dual Market/Freely floating & An official rate is pegged to the US Dollar. \\
\hline September $1975-$ October 7, 1977 & Freely falling/Freely floating & There are multiple exchange rates. \\
\hline October 7, 1977-December 13, 1977 & Freely falling/Freely floating & There is a short-lived unification of exchange rates. \\
\hline May $10,1978-$ February 29,1984 & $\begin{array}{l}\text { Freely Falling/Freely floating/Parallel } \\
\text { market }\end{array}$ & $\begin{array}{l}\text { There are multiple exchange rates. There was a short-lived } \\
\text { unification of rates in } 1982 \text {. There was a pre-announced } \\
\text { crawling peg during this period. }\end{array}$ \\
\hline February 29, 1984- August 2, 1986 & Freely falling/Freely floating & $\begin{array}{l}\text { The crawling peg policy is abandoned. There are multiple } \\
\text { rates. An official rate is pegged to the US Dollar from } \\
\text { September } 1985 \text { to December } 1986 \text { and again from January } \\
1988 \text { to August } 1988 \text {. On February 1, } 1985 \text { the Inti replaced } \\
\text { the Sol. }\end{array}$ \\
\hline August 2, 1986-December 2, 1986 & Freely falling/Freely floating & Yet another short-lived unification. \\
\hline December 2, 1986-August 9, 1990 & Freely falling/Freely floating & $\begin{array}{l}\text { There are multiple exchange rates. Parallel market } \\
\text { premium hits } 1,067 \% \text { in August } 1988 \text { - September } 1988 \\
\text { classifies as a "hyperfloat." The } 12-\text { month rate of inflation } \\
\text { reaches } 12,378 \% \text {. }\end{array}$ \\
\hline August 9, 1990-November 1993 & Freely falling/Freely floating & Unification of rates. \\
\hline November 1993-March 1999 & $\begin{array}{l}\text { De facto crawling band around US } \\
\text { Dollar }\end{array}$ & $\begin{array}{l}\text { Band width is }+/-2 \% \text {. Parallel market premium in single } \\
\text { digits. }\end{array}$ \\
\hline April 1999-December 2001 & De facto peg to US Dollar & \\
\hline
\end{tabular}

Notes: Reference currency is the US Dollar.

Philippines

\begin{tabular}{|c|c|c|}
\hline Date & $\begin{array}{l}\text { Classification: } \\
\text { Primary/Secondary/Tertiary }\end{array}$ & Comments \\
\hline March 2, 1903-1942 & Peg to US Dollar & \\
\hline $1942-1945$ & Peg to Yen/Freely falling & Circulation of Gumpyo, or Military Yen \\
\hline $1945-$ & Managed floating & $\begin{array}{l}\text { The official rate is re-pegged at the same US Dollar parity } \\
\text { as in } 1903 .\end{array}$ \\
\hline March 1950-April 25, 1960 & $\begin{array}{l}\text { De facto crawling band around US } \\
\text { Dollar }\end{array}$ & $\begin{array}{l}\text { Band width is }+/-5 \% \text {. The official rate remains pegged to } \\
\text { the US Dollar. }\end{array}$ \\
\hline April 25, 1960-November 7, 1965 & De facto peg to US Dollar & $\begin{array}{l}\text { There are multiple exchange rates. After reaching a peak of } \\
124 \% \text { in January 1962, parallel market premia settles in } \\
\text { single digits. }\end{array}$ \\
\hline November 7, 1965-February 21, 1970 & Peg to US Dollar & \\
\hline February 21, 1971-December 31, 1972 & $\begin{array}{l}\text { De facto crawling band around US } \\
\text { Dollar/Dual Market }\end{array}$ & $\begin{array}{l}\text { Band width is }+/-5 \% \text {. The official rate is pegged to the US } \\
\text { Dollar. }\end{array}$ \\
\hline December 31, 1972-September 1983 & $\begin{array}{l}\text { De facto crawling band around US } \\
\text { Dollar/Parallel Market }\end{array}$ & $\begin{array}{l}\text { Band width is }+/-5 \% \text {. The official rate is pegged to the US } \\
\text { Dollar. }\end{array}$ \\
\hline October $1983-$ October 15,1984 & $\begin{array}{l}\text { Freely falling/Managed } \\
\text { floating/parallel market }\end{array}$ & $\begin{array}{l}\text { The official rate remains pegged to the US Dollar. Parallel } \\
\text { market premia reaches } 50 \% \text { on January 1984, From June } \\
1984 \text { to October there were multiple rates. }\end{array}$ \\
\hline October 14, 1984-February 1985 & Freely falling/Managed floating & $\begin{array}{l}\text { The Philippine peso's official link with the US Dollar is } \\
\text { ended. }\end{array}$ \\
\hline March 1985-April, 1992 & De facto crawling peg to US Dollar & \\
\hline May 1992-April 1993 & De facto band around US Dollar & Band width is $+/-2 \%$. \\
\hline May 1993-August 1995 & De facto band around US Dollar & Band width is $+/-5 \%$. \\
\hline September, 1995-June 1997 & De facto peg to US Dollar & \\
\hline July 1997-December 1997 & Freely falling/Freely floating & Parallel market premia peaked at $17 \%$ on July 1997. \\
\hline December 1997-December 2001 & Managed floating & \\
\hline
\end{tabular}

Notes: Reference currency is the US Dollar. 
Poland

\begin{tabular}{|l|l|l|}
\hline Date & $\begin{array}{l}\text { Classification: } \\
\text { Primary/Secondary/Tertiary }\end{array}$ & Comments \\
\hline January 1988- March 15, 1989 & Freely falling/Freely floating & There are multiple rates. \\
\hline March 15, 1989-January 1, 1990 & $\begin{array}{l}\text { Freely falling/Freely floating/Dual } \\
\text { Market }\end{array}$ & Parallel market is legalized. \\
\hline January 1, 1990-May 17, 1991 & Freely falling/Dual Market & Official rate is pegged to US Dollar. \\
\hline May 17, 1991-April 1993 & Freely falling/Dual Market & $\begin{array}{l}\text { Official rate is set as a pre announced crawling peg to US } \\
\text { Dollar. }\end{array}$ \\
\hline May 1993-May 16, 1995 & Dual Market & $\begin{array}{l}\text { Official rate is set as a pre announced crawling peg to US } \\
\text { Dollar. There is no parallel market data for this period. }\end{array}$ \\
\hline May 16, 1995-February, 25, 1998 & De facto crawling band around Euro & $\begin{array}{l}\text { De facto band width is +/-5\%. There is a pre announced } \\
\text { crawling band around the DM and US Dollar that is } \\
+/-7 \% .\end{array}$ \\
\hline February 25, 1998-October 29, 1998 & De facto crawling band around Euro & $\begin{array}{l}\text { De facto band width is }+/-5 \% \text {. There is a pre announced } \\
\text { crawling band around the DM and US Dollar that is } \\
+/-10 \% .\end{array}$ \\
\hline October 29, 1998-March 24, 1999 & $\begin{array}{l}\text { De facto crawling band around } \\
\text { DM/Euro } \\
\text { crawling band around the DM and US Dollar that is } \\
+/-12.5 \% .\end{array}$ \\
\hline March 24, 1999-April 12, 2000 & De facto crawling band around Euro & $\begin{array}{l}\text { De facto band width is +/-5\%. There is a pre announced } \\
\text { crawling band around the DM and US Dollar that is } \\
+/-15 \% .\end{array}$ \\
\hline April 12, 2000-December 2001 & Managed floating & \\
\hline
\end{tabular}

Notes: Reference currencies are the US Dollar, the DM, and the Euro.

Portugal

\begin{tabular}{|l|l|l|}
\hline Date & $\begin{array}{l}\text { Classification: } \\
\text { Primary/Secondary/Tertiary }\end{array}$ & Comments \\
\hline April 28, 1928- November 14,1939 & Peg to Pound Sterling & \\
\hline November 14, 1939-March 19,1973 & Peg to US Dollar & Band width +/-5\%. The parallel premia shot up in August \\
\hline March 19, 1973-February 1981 & De facto crawling band around DM & $\begin{array}{l}1975 \text { to 67\% and again in February 1977ahead of large } \\
\text { depreciations. }\end{array}$ \\
\hline February 1981-August 1993 & De facto crawling band around DM & Band width is +/-2\%. \\
\hline September 1992-June 1993 & De facto crawling peg to DM & \\
\hline July 1993-January 1, 1999 & De facto peg to DM & Euro \\
\hline January 1, 1999-December 2001 & Currency union & \\
\hline
\end{tabular}

Notes: Reference currencies are the US Dollar, the DM, and the Euro.

Romania

\begin{tabular}{|l|l|l|}
\hline Date & $\begin{array}{l}\text { Classification: } \\
\text { Primary/Secondary/Tertiary }\end{array}$ & Comments \\
\hline July 1957-January 1990 & Dual Market & $\begin{array}{l}\text { There are multiple exchange rates-25 rates were applied to } \\
\text { exports alone. On July 1, 1983 the number of rates was } \\
\text { reduced to two. }\end{array}$ \\
\hline February 1990-November 11,1991 & $\begin{array}{l}\text { Freely falling/Freely floating/Dual } \\
\text { Market }\end{array}$ & CPI data available only from October 1989 \\
\hline November 11, 1991-March 2001 & Freely falling/Freely floating & Band width is $+/-5 \%$. \\
\hline April 2001-December 2001 & De facto crawling band & \multicolumn{2}{|l}{} \\
\hline
\end{tabular}

Notes: Reference currencies are the DM, the Euro, and the US Dollar.

Russian Federation

\begin{tabular}{|l|l|l|}
\hline Date & $\begin{array}{l}\text { Classification: } \\
\text { Primary/Secondary/Tertiary }\end{array}$ & Comments \\
\hline January, 1992-June 1, 1995 & Freely falling/Market & There is no price data before this date. \\
\hline July 6, 1995-July 1996 & Freely falling/ Market & $\begin{array}{l}\text { Pre announced crawling band around US Dollar for the } \\
\text { official rate. }\end{array}$ \\
\hline August 1996-August 17, 1998 & Dual Market & $\begin{array}{l}\text { Pre announced crawling band around US Dollar for the } \\
\text { official rate. }\end{array}$ \\
\hline August 17, 1998-November 1999 & Freely falling/Dual Market & $\begin{array}{l}\text { The band was widened on August 17 and eliminated on } \\
\text { September 2. On June 29, 1999 the two rates are unified } \\
\text { temporarily. }\end{array}$ \\
\hline December 1999-December 2001 & $\begin{array}{l}\text { De facto crawling band around US } \\
\text { Dollar }\end{array}$ & Bandth +/-2\%. There are multiple rates. \\
\hline
\end{tabular}

Notes: Reference currency is the US Dollar. 
Saint Kitts and Nevis

East Caribbean Central Bank States are: Anguilla, Antigua and Barbuda, Dominica, Grenada, Montserrat, Saint Kitts and Nevis, Saint Lucia, Saint Vincent and the Grenadines

\begin{tabular}{|l|l|l|}
\hline Date & $\begin{array}{l}\text { Classification: } \\
\text { Primary/Secondary/Tertiary }\end{array}$ & Comments \\
\hline 1935-October 6, 1965 & Peg to Pound Sterling & $\begin{array}{l}\text { British West Indies Dollar is introduced. It is issued by the } \\
\text { East Caribbean Monetary Authority. }\end{array}$ \\
\hline October 6, 1965-July 7, 1976 & Peg to Pound Sterling & East Caribbean Dollar replaces British West Indies Dollar. \\
\hline July 7, 1976-December 2001 & Peg to US Dollar & $\begin{array}{l}\text { ON October 1, 1983 the East Caribbean Central Bank } \\
\text { replaces the East Caribbean Monetary Authority. }\end{array}$ \\
\hline
\end{tabular}

Notes: Reference currency is US Dollar.

Saint Lucia

East Caribbean Central Bank States are: Anguilla, Antigua and Barbuda, Dominica, Grenada, Montserrat, Saint Kitts and Nevis, Saint Lucia, Saint Vincent and the Grenadines

\begin{tabular}{|l|l|l|}
\hline Date & $\begin{array}{l}\text { Classification: } \\
\text { Primary/Secondary/Tertiary }\end{array}$ & Comments \\
\hline 1935-October 6, 1965 & Peg to Pound Sterling & $\begin{array}{l}\text { British West Indies Dollar is introduced. It is issued by the } \\
\text { East Caribbean Monetary Authority. }\end{array}$ \\
\hline October 6, 1965-July 7, 1976 & Peg to Pound Sterling & East Caribbean Dollar replaces British West Indies Dollar. \\
\hline July 7, 1976-December 2001 & Peg to US Dollar & $\begin{array}{l}\text { ON October 1, 1983 the East Caribbean Central Bank } \\
\text { replaces the East Caribbean Monetary Authority. }\end{array}$ \\
\hline
\end{tabular}

Notes: Reference currency is US Dollar.

Saint Vincent and the Grenadines

East Caribbean Central Bank States are: Antigua and Barbuda, Dominica, Grenada, Saint Kitts and Nevis, Saint Lucia, Saint Vincent and the Grenadines

\begin{tabular}{|l|l|l|}
\hline Date & $\begin{array}{l}\text { Classification: } \\
\text { Primary/Secondary/Tertiary }\end{array}$ & Comments \\
\hline 1935-October 6, 1965 & Peg to Pound Sterling & $\begin{array}{l}\text { British West Indies Dollar is introduced. It is issued by the } \\
\text { East Caribbean Monetary Authority. }\end{array}$ \\
\hline October 6, 1965-July 7, 1976 & Peg to Pound Sterling & East Caribbean Dollar replaces British West Indies Dollar. \\
\hline July 7, 1976-December 2001 & Peg to US Dollar & $\begin{array}{l}\text { ON October 1, 1983 the East Caribbean Central Bank } \\
\text { replaces the East Caribbean Monetary Authority. }\end{array}$ \\
\hline
\end{tabular}

\begin{tabular}{|c|c|c|}
\hline \multicolumn{3}{|l|}{ San Marino } \\
\hline Date & $\begin{array}{l}\text { Classification: } \\
\text { Primary/Secondary/Tertiary }\end{array}$ & Comments \\
\hline January 1,1999 & $\begin{array}{l}\text { Exchange rate arrangement with no } \\
\text { separate legal tender }\end{array}$ & $\begin{array}{l}\text { Italian Lira. Some local coins were minted in } 186,1898, \\
1925 \text { and } 1932 .\end{array}$ \\
\hline January 1, 1999-December 2001 & $\begin{array}{l}\text { Exchange rate arrangement with no } \\
\text { separate legal tender }\end{array}$ & Euro \\
\hline \multicolumn{3}{|l|}{ Saudi Arabia } \\
\hline Date & $\begin{array}{l}\text { Classification: } \\
\text { Primary/Secondary/Tertiary }\end{array}$ & Comments \\
\hline January 22, 1928-June 4, 1958 & Peg to British gold Sovereign & \\
\hline June $4,1958-$ January 8,1960 & $\begin{array}{l}\text { De facto band around US Dollar/Dual } \\
\text { Market }\end{array}$ & $\begin{array}{l}\text { Band width is }+/-2 \% \text {. Since December } 1959 \text { the parallel } \\
\text { market premia is nil-prior to that time its oscillated in the } \\
20-30 \% \text { range. }\end{array}$ \\
\hline January 8, 1960-March 15, 1975 & Peg to US Dollar & \\
\hline March 15, 1975-December 2001 & De facto US Dollar peg & Officially the Riyal is pegged to the SDR. \\
\hline
\end{tabular}

Notes: Reference currencies are the US Dollar and the SDR.

Senegal

Central Bank of West African States: Benin, Burkina Faso, Cote D'Ivoire, Guinea-Bissau, Mali, Niger, Senegal, and Togo ${ }^{1}$

\begin{tabular}{|l|l|l|}
\hline Date & $\begin{array}{l}\text { Classification: } \\
\text { Primary/Secondary/Tertiary }\end{array}$ & Comments \\
\hline June 29, 1901- February 2, 1943 & Peg to French Franc & $\begin{array}{l}\text { Banque de l'Afrique Occidentale is allowed to issue bank } \\
\text { notes. Exchange controls are introduced in Franc zone on } \\
\text { September 9, 1939. }\end{array}$ \\
\hline February 2, 1943- December 26. 1945 & Peg to US Dollar and Pound Sterling & On December 1942 incorporated in the Sterling Area \\
\hline December 26. 1945- May 12, 1962 & Peg to French Franc & Return to Franc Zone. The CFA Franc is introduced. \\
\hline May 12, 1962-September 9, 1971 & Peg to French Franc & Creation of the Central Bank of West African States \\
\hline September 9, 1971-March 21, 1974 & $\begin{array}{l}\text { De facto peg to French Franc/Dual } \\
\text { Market }\end{array}$ & Very low parallel market premium. \\
\hline March 21, 1974-December 1993 & Peg to French Franc & \\
\hline January 1994-November 1994 & Peg to French Franc/Freely falling & One 100\% devaluation. \\
\hline December 1994-January 1, 1999 & Peg to French Franc & \\
\hline January 1, 1999-December 2001 & Peg to Euro & \\
\hline
\end{tabular}

${ }^{1}$ Mali joined the currency arrangement at a later

Note: Reference currencies are the French Franc and the Euro 


Singapore
\begin{tabular}{|l|l|l|}
\hline Date & $\begin{array}{l}\text { Classification: } \\
\text { Primary/Secondary/Tertiary }\end{array}$ & Comments \\
\hline February 1906-June 25, 1972 & Peg to Pound Sterling & Malayan/Straits Dollar \\
\hline June 12, 1967-June 25, 1972 & Peg to Pound Sterling & $\begin{array}{l}\text { Introduction of the independent and separate currencies of } \\
\text { Singapore, Malaysia, and Brunei }\end{array}$ \\
\hline June 25, 1972-June 21, 1973 & Peg to US Dollar & \\
\hline June 21, 1973-November 1998 & $\begin{array}{l}\text { De facto moving band around the US } \\
\text { Dollar }\end{array}$ & $\begin{array}{l}\text { Band width is +/-2\%. Officially adjusted on the basis of a } \\
\text { basket of currencies }\end{array}$ \\
\hline December 1998-December 2001 & Managed floating & \\
\hline
\end{tabular}

Notes: Reference currencies are is the US Dollar and theYen.

Slovak Republic

\begin{tabular}{|l|l|l|}
\hline Date & $\begin{array}{l}\text { Classification: } \\
\text { Primary/Secondary/Tertiary }\end{array}$ & Comments \\
\hline February 8, 1993-March 1993 & Freely falling & The Slovak Koruna is introduced. \\
\hline April, 1993-July 31,1996 & De facto crawling band around DM & Band width is $+/-2 \%$ \\
\hline July 31, 1996-January 1, 1997 & & $\begin{array}{l}\text { De facto band width is }+/-2 \% \text {. Pre announced crawling } \\
\text { band is }+/-5 \% \text { wide. The official basket also includes the } \\
\text { US Dollar with a lower weight than the DM. }\end{array}$ \\
\hline January 1, 1997-September 1997 & $\begin{array}{l}\text { De facto crawling band around the } \\
\text { DM }\end{array}$ & $\begin{array}{l}\text { De facto band width is }+/-2 \% \text {. Pre announced crawling } \\
\text { band is }+/-7 \% \text { wide. }\end{array}$ \\
\hline September 1997-October 1, 1998 & De facto crawling band around DM & $\begin{array}{l}\text { De facto band width is }+/-5 \% \text {. Pre announced crawling } \\
\text { band is }+/-7 \% \text { wide. }\end{array}$ \\
\hline October 1, 1998-December 2001 & Managed floating & $\begin{array}{l}100 \% \text { of the observations remain within a }+/-5 \% \text { band of } \\
\text { the DM/Euro. }\end{array}$ \\
\hline
\end{tabular}

Notes: Reference currencies are the DM, the Euro, and the US Dollar.

Slovenia

\begin{tabular}{|l|l|l|}
\hline Date & $\begin{array}{l}\text { Classification: } \\
\text { Primary/Secondary/Tertiary }\end{array}$ & Comments \\
\hline October 1991-February 1992 & Freely falling & $\begin{array}{l}\text { There is no price data before this date. The Tolar is } \\
\text { introduced to replace the Yugoslav Dinar. }\end{array}$ \\
\hline March 1992-March 1993 & $\begin{array}{l}\text { Freely falling/De facto crawling band } \\
\text { around DM }\end{array}$ & Band width is $+/-2 \%$. \\
\hline April 1993-January 1, 1999 & De facto crawling band around DM & Band width is $+/-2 \%$. \\
\hline October 1996-December 2001 & De facto crawling band around Euro & Band width is $+/-2 \%$. \\
\hline
\end{tabular}

Notes: Reference currency is the US Dollar.

South Africa

\begin{tabular}{|c|c|c|}
\hline Date & $\begin{array}{l}\text { Classification: } \\
\text { Primary/Secondary/Tertiary }\end{array}$ & Comments \\
\hline 1920-February 14,1961 & Peg to Pound Sterling & The South African Pound is introduced. \\
\hline February 14,1961 -August 23,1971 & Peg to Pound Sterling & The Rand is introducing to replace the Pound. \\
\hline August 23, 1971-December 22, 1971 & Peg to US Dollar & \\
\hline $\begin{array}{l}\text { December 21, 1971-October 24, } \\
1972\end{array}$ & Peg to Pound Sterling & \\
\hline October 24, 1972-January 24, 1979 & Managed floating/Parallel market & $\begin{array}{l}\text { The official rate is pegged to US Dollar. The parallel } \\
\text { premium fluctuates considerably and peaks at } 62 \% \text { on April } \\
1976 \text {. }\end{array}$ \\
\hline January $24,1979-$ February 7,1983 & Managed floating/Dual Rate & $\begin{array}{l}\text { The official rate is de facto peg to the US Dollar until April } \\
\text { 1981. Premium rises to a maximum of } 27 \% \text { in this period. }\end{array}$ \\
\hline $\begin{array}{l}\text { February 7, 1983- September 2, } \\
1985\end{array}$ & Managed floating & \\
\hline September 2, 1985-March 13, 1995 & Dual Rate/Managed floating & $\begin{array}{l}\text { There are several spikes in the premium including in } 1985 \\
\text { and } 1987 \text {, when the premium approached } 40 \% \text {. }\end{array}$ \\
\hline March 13, 1995-December 2001 & Freely floating & \\
\hline
\end{tabular}

Notes: Reference currencies are the US Dollar, and the Pound Sterling. 
South Korea

\begin{tabular}{|c|c|c|}
\hline Date & $\begin{array}{l}\text { Classification: } \\
\text { Primary/Secondary/Tertiary }\end{array}$ & Comments \\
\hline October 1945-November 1948 & $\begin{array}{l}\text { De facto band around US } \\
\text { Dollar/Parallel market }\end{array}$ & $\begin{array}{l}\text { Band width is }+/-5 \% \text {. The official rate is pegged to the US } \\
\text { Dollar, but there are frequent and large devaluations. }\end{array}$ \\
\hline December 1948-February 15,1953 & $\begin{array}{l}\text { Freely falling/De facto band around } \\
\text { US Dollar/Parallel market }\end{array}$ & $\begin{array}{l}\text { Band width is }+/-5 \% \text {. The official rate is pegged to the US } \\
\text { Dollar, but there are frequent and large devaluations. In } \\
1947 \text { the parallel market premium hit } 2,400 \% \text {. }\end{array}$ \\
\hline February 15, 1953-December 1954 & $\begin{array}{l}\text { De facto crawling band around US } \\
\text { Do/Parallel market }\end{array}$ & $\begin{array}{l}\text { Band width is }+/-2 \% \text {. Hwan issued to replace Won. On } \\
\text { June } 10,1962 \text { Won is reintroduced. There are multiple } \\
\text { exchange rates. Parallel market premium around } 350 \% \text {. }\end{array}$ \\
\hline January 1955-December 1955 & $\begin{array}{l}\text { Freely falling/ De facto crawling band } \\
\text { around US Dollar/Parallel market }\end{array}$ & Band width is $+/-2 \%$. There are multiple exchange rates. \\
\hline January 1956-May 3, 1964 & $\begin{array}{l}\text { De facto crawling band around US } \\
\text { Dollar/Parallel market }\end{array}$ & $\begin{array}{l}\text { There are multiple exchange rates. Band width is }+/-2 \% \text {. } \\
\text { Parallel market premium above } 100 \% \text { through } 1960 \text { and } \\
\text { oscillating in the } 20-120 \% \text { range through } 1965\end{array}$ \\
\hline May 3, 1964-April 1974 & $\begin{array}{l}\text { Crawling band to US Dollar/Parallel } \\
\text { market }\end{array}$ & $\begin{array}{l}\text { Band width is }+/-5 \% \text {. Parallel market premia mostly in } \\
\text { single digits. }\end{array}$ \\
\hline May $1974-$ February 27,1980 & Peg to US Dollar & Parallel market premia rose to $28 \%$ in February 1980. \\
\hline February $27,1980-$ July, 1980 & De facto crawling peg to US Dollar & Officially pegged to a basket of currencies and the SDR \\
\hline March 2, 1990-September 2, 1991 & $\begin{array}{l}\text { Pre announced crawling band around } \\
\text { US Dollar }\end{array}$ & $\begin{array}{l}\text { Band width }+/-0.4 \% \text {. This fits into our definition of } \\
\text { crawling peg. }\end{array}$ \\
\hline September 2, 1991-July 1, 1992 & $\begin{array}{l}\text { Pre announced crawling band around } \\
\text { US Dollar }\end{array}$ & $\begin{array}{l}\text { Band width }+/-0.6 \% \text {. This fits into our definition of } \\
\text { crawling peg. }\end{array}$ \\
\hline July 1, 1992-October 1, 1993 & $\begin{array}{l}\text { Pre announced crawling band around } \\
\text { US Dollar }\end{array}$ & $\begin{array}{l}\text { Band width }+/-0.8 \% \text {. This fits into our definition of } \\
\text { crawling peg. }\end{array}$ \\
\hline October 1, 1993-November 1, 1994 & $\begin{array}{l}\text { Pre announced crawling band around } \\
\text { US Dollar }\end{array}$ & $\begin{array}{l}\text { Band width }+/-0.1 \% \text {. This fits into our definition of } \\
\text { crawling peg. }\end{array}$ \\
\hline November 1, 1994-December 1, 1995 & De facto crawling peg to US Dollar & $\begin{array}{l}\text { Pre announced band is }+/-1.5 \% \text {. Does not fit into our } \\
\text { definition of peg, which stops at a }+/-1 \% \text { band. }\end{array}$ \\
\hline December 1, 1995-November, 1997 & De facto crawling peg to US Dollar & Officially the pre announced band is $+/-2.25 \%$ \\
\hline December 17, 1997-June 1998 & Freely falling & The won was allowed to float. \\
\hline July 1998-December 2001 & Freely floating & \\
\hline
\end{tabular}

Notes: Reference currency is the US Dollar.

Spain

\begin{tabular}{|c|c|c|}
\hline Date & $\begin{array}{l}\text { Classification: } \\
\text { Primary/Secondary/Tertiary }\end{array}$ & Comments \\
\hline September 1939- August 25, 1946 & Peg to US Dollar & \\
\hline August $25,1946-$ October 1948 & Managed floating/Parallel market & There are multiple exchange rates \\
\hline November 1948-May 1951 & $\begin{array}{l}\text { De facto band around US } \\
\text { Dollar/Parallel market }\end{array}$ & Band width $+/-5 \%$. There are multiple exchange rates \\
\hline June 1951-July 17, 1959 & $\begin{array}{l}\text { De facto band around US } \\
\text { Dollar/Parallel Market }\end{array}$ & Band width $+/-2 \%$. There are multiple exchange rates \\
\hline July $17,1959-$ January 22,1974 & Peg to US Dollar/Parallel Market & Frequent devaluations \\
\hline January 22, 1974-December 1980 & $\begin{array}{l}\text { De facto crawling band around US } \\
\text { Dollar }\end{array}$ & $\begin{array}{l}\text { Band width }+/-2 \% \text {. Until July } 12,1977 \text { the peseta was } \\
\text { officially still pegged to the US Dollar - but with continuous } \\
\text { adjustments. }\end{array}$ \\
\hline January 1981-April 1994 & De facto crawling band around DM & Band width $+/-2 \%$. \\
\hline May 1994-January 1, 1999 & De facto peg to DM & \\
\hline January 1, 1999-December 2001 & Currency Union & Euro \\
\hline
\end{tabular}

Notes: Reference currencies are the US Dollar, the DM, and the Euro. 
Sri Lanka

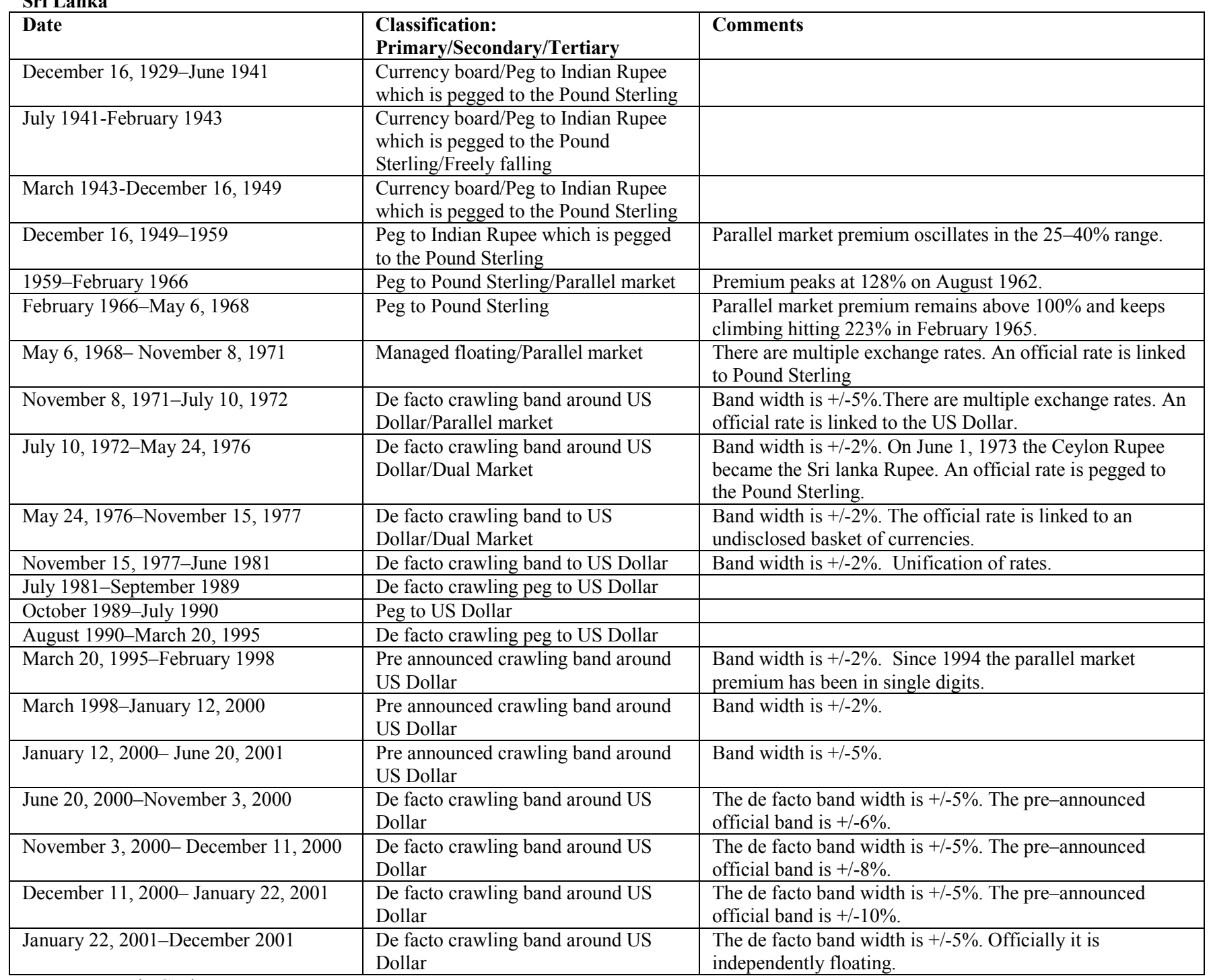

Notes: Formerly Ceylon. 


\begin{tabular}{|c|c|c|}
\hline Date & $\begin{array}{l}\text { Classification: } \\
\text { Primary/Secondary/Tertiary }\end{array}$ & Comments \\
\hline November 20, 1815-May 10, 1940 & Peg to Dutch Guilder & $\begin{array}{l}\text { Suriname Guilder represented a colonial issue of the Dutch } \\
\text { Guilder }\end{array}$ \\
\hline July 1974-March 1975 & $\begin{array}{l}\text { Crawling band around US } \\
\text { Dollar/Parallel market }\end{array}$ & $\begin{array}{l}\text { Band width is }+/-2 \% \text {. The official rate is still pegged to the } \\
\text { US Dollar. }\end{array}$ \\
\hline May 1982-March 1986 & Managed floating/Parallel market & $\begin{array}{l}\text { The official rate is still pegged to the US Dollar but there } \\
\text { are large oscillations in the exchange rate in the parallel } \\
\text { market. }\end{array}$ \\
\hline April 1986-December 1987 & $\begin{array}{l}\text { Freely falling/Managed } \\
\text { floating/Parallel market }\end{array}$ & The official rate is still pegged to the US Dollar \\
\hline January $1988-$ June 15,1989 & Managed floating/Parallel market & \\
\hline July 11, 1994-November, 1995 & $\begin{array}{l}\text { Freely falling/De facto crawling band } \\
\text { around US Dollar }\end{array}$ & $\begin{array}{l}\text { The official rate is no longer pegged to the US Dollar. Band } \\
\text { width is }+/-5 \% \text {. The multiple exchange rate system was } \\
\text { unified-however the informal parallel market remains } \\
\text { extremely active. }\end{array}$ \\
\hline December 1995-January 1998 & $\begin{array}{l}\text { De facto crawling band around US } \\
\text { Dollar/Parallel Market }\end{array}$ & $\begin{array}{l}\text { Band width is }+/-5 \% \text {. The official rate is re-pegged to the } \\
\text { US Dollar. }\end{array}$ \\
\hline February 1998-January 1, 1999 & Freely falling/Dual Market & $\begin{array}{l}\text { The official exchange is pegged to the US Dollar. There is } \\
\text { also a parallel market premia is in single digits through } \\
\text { December 1998. There are separate rates for some imports. }\end{array}$ \\
\hline January $1,1999-$ October 3,2000 & $\begin{array}{l}\text { Freely falling/Crawling Band around } \\
\text { US Dollar/Dual Market }\end{array}$ & Band width is $+/-3 \%$. There are multiple exchange rates. \\
\hline
\end{tabular}

Notes: Reference currencies are the US Dollar and the Dutch Guilder.

Swaziland

\begin{tabular}{|l|l|l|}
\hline Date & $\begin{array}{l}\text { Classification: } \\
\text { Primary/Secondary/Tertiary }\end{array}$ & Comments \\
\hline 1920-February 14, 1961 & No separate legal tender & South Africa Pound \\
\hline February 14, 1961-September 6, 1974 & No separate legal tender & South Africa Rand \\
\hline September 6, 1974- January 24, 1979 & Peg to South Africa Rand & The Ligaleni is introduced. \\
\hline January 24, 1979-February 7, 1983 & $\begin{array}{l}\text { De facto peg to South Africa } \\
\text { Rand/Dual Market }\end{array}$ & \\
\hline February 7, 1983- September 2, 1985 & Peg to South Africa Rand & $\begin{array}{l}\text { On May 1986 the South African Rand ceased to be legal } \\
\text { tender. Parallel market premium peaks at 30\% on May 1987. }\end{array}$ \\
\hline September 2, 1985-March 13,1995 & $\begin{array}{l}\text { De facto peg to South Africa } \\
\text { Rand/Dual Market }\end{array}$ & Parallel market premia in single digits. \\
\hline March 13, 1995-December 2001 & Peg to South Africa Rand &
\end{tabular}

Notes: Reference currencies are the US Dollar and the South African Rand. 
Sweden

\begin{tabular}{|l|l|l|}
\hline Date & $\begin{array}{l}\text { Classification: } \\
\text { Primary/Secondary/Tertiary }\end{array}$ & Comments \\
\hline 1920-April 1, 1924 & Suspension of convertibility & \\
\hline April 1, 1924- September 28, 1931 & Peg & Gold Standard \\
\hline September 28, 1931-September 1939 & Peg to Pound Sterling & $\begin{array}{l}\text { Suspended convertibility into gold and joined the Sterling } \\
\text { Area. }\end{array}$ \\
\hline $1940-1946$ & Capital controls & $\begin{array}{l}\text { Band width is +/-5\%. Official rate is pegged to the US } \\
\text { Dollar. On March 1949, five months before the devaluation } \\
\text { of the official rate, the parallel market premium peaked at } \\
\text { 49\% -although subsequently declining it would remain in } \\
\text { double digits through early 1953. }\end{array}$ \\
\hline July 13, 1946-February 1952 & Bollar/Parallel Market \\
\hline March 1952-September 1954 & De facto Band around US Dollar & On July 1, 1959 Investment Dollar Krona is introduced. \\
\hline March 19, 1973- November 19, 1992 & Peg to US Dollar & Be facto crawling around DM \\
\hline November 19, 1992-December 2001 & Managed floating & \\
\hline
\end{tabular}

Notes: Reference currencies are the US Dollar, the DM, and the Euro.

Switzerland

\begin{tabular}{|c|c|c|}
\hline Date & $\begin{array}{l}\text { Classification: } \\
\text { Primary/Secondary/Tertiary }\end{array}$ & Comments \\
\hline November 1934-June 1935 & Dual Market & \\
\hline September 27, 1936-January 19, 1942 & Peg to US Dollar & \\
\hline January 19, 1942-June 1946 & $\begin{array}{l}\text { De facto band around US Dollar/Dual } \\
\text { Market }\end{array}$ & Band width is $+/-5 \%$. Exchange controls \\
\hline July $1946-$ September 25,1949 & $\begin{array}{l}\text { De facto band around US Dollar/Dual } \\
\text { Market }\end{array}$ & Band width is $+/-2 \%$. \\
\hline September 25, 1949-January 23, 1973 & Peg to US Dollar & Controls are lifted. \\
\hline January 23, 1973- September 1981 & Managed floating & \\
\hline September 1981-December 2001 & De facto moving band around DM & Band width is $+/-2 \%$. \\
\hline
\end{tabular}

Notes: Reference currencies are the US Dollar, the DM, and the Euro.

Syrian Arab Republic

\begin{tabular}{|c|c|c|}
\hline Date & $\begin{array}{l}\text { Classification: } \\
\text { Primary/Secondary/Tertiary }\end{array}$ & Comments \\
\hline 1918-May 1, 1920 & $\begin{array}{l}\text { Exchange rate arrangement with no } \\
\text { separate legal tender }\end{array}$ & Egyptian pound, British occupation \\
\hline May $1,1920-$ January 1,1948 & Peg to French Franc & Creation of Lebanon-Syrian Pound. \\
\hline January 1,1948 & Parallel Market & $\begin{array}{l}\text { Split of Lebanon and Syrian monetary system. There are } \\
\text { multiple exchange rates }\end{array}$ \\
\hline January $1970-$ July 1973 & De facto band around US Dollar & Band width is $+/-2 \%$. Data on parallel market begins. \\
\hline August 1973-April 24, 1976 & $\begin{array}{l}\text { De facto crawling band around US } \\
\text { Dollar/Parallel market }\end{array}$ & Band width is $+/-5 \%$. \\
\hline April 24, 1976-April 22, 1981 & $\begin{array}{l}\text { De facto crawling band around US } \\
\text { Dollar/Parallel market }\end{array}$ & $\begin{array}{l}\text { There are multiple exchange rates. All official rates are } \\
\text { pegged to the US Dollar, }\end{array}$ \\
\hline April 22, 1981-May 24, 1982 & $\begin{array}{l}\text { De facto crawling band around US } \\
\text { Dollar/Dual market }\end{array}$ & \\
\hline May 24, 1982-January 1, 1988 & $\begin{array}{l}\text { De facto crawling band around US } \\
\text { Dollar/Parallel market }\end{array}$ & $\begin{array}{l}\text { There are multiple exchange rates All official rates are } \\
\text { pegged to the US Dollar. In the run-up to the devaluation } \\
\text { parallel market premia hit a record high of } 1,047 \% \text { on } \\
\text { December } 1987\end{array}$ \\
\hline January 1, 1988-December 2001 & $\begin{array}{l}\text { De facto crawling band around US } \\
\text { Dollar/Parallel market }\end{array}$ & $\begin{array}{l}\text { There are multiple exchange rates. All official rates are } \\
\text { pegged to the US Dollar, one } 186 \% \text { devaluation, January } \\
\text { 1988. Parallel premia remained in the } 250-400 \% \text { range } \\
\text { through December } 1998 \text {, when the data ends. }\end{array}$ \\
\hline
\end{tabular}

Notes: Reference currency is the US Dollar.

Tajikistan

\begin{tabular}{|l|}
\hline Date \\
\hline January 1992-December 1995 \\
\hline January 1996-October 1997 \\
\hline October 1997- September 1998 \\
\hline October 1998-July 2001 \\
\hline
\end{tabular}

\section{Classification:}

Primary/Secondary/Tertiary Freely falling/Dual Market

Freely falling/Freely floating

Peg to US Dollar/Freely falling

Freely falling/Freely floating

\section{Comments}

The Tajik Ruble was introduced on May 10, 1995. There is no price data before this date.

On October 26, 2000, the Tajik Somoni replaced the Tajuk

Ruble. More recent inflation data is not available. 
Tanzania

\begin{tabular}{|c|c|c|}
\hline Date & $\begin{array}{l}\text { Classification: } \\
\text { Primary/Secondary/Tertiary }\end{array}$ & Comments \\
\hline 1906-January 1, 1922 & Currency union/Peg & $\begin{array}{l}\text { Pound Sterling, East African Rupee is created German } \\
\text { until 1918, British subsequently }\end{array}$ \\
\hline January 1, 1922-June 14, 1966 & Currency union/Peg & Pound Sterling, East African Shilling is created \\
\hline June 14,1966 -August 25,1971 & Peg to Pound Sterling & Tanzania Shilling is introduced \\
\hline August 25, 1971-November 1973 & Managed floating/Parallel market & Official rate is pegged to the US Dollar. \\
\hline December 1973-March 1975 & $\begin{array}{l}\text { Freely falling/Managed } \\
\text { floating/Parallel market }\end{array}$ & Official rate is pegged to the US Dollar. \\
\hline April 1975-October 27, 1975 & Managed floating/Parallel market & Official rate is pegged to the US Dollar. \\
\hline October 27, 1975-January 20, 1979 & Managed floating/Parallel market & $\begin{array}{l}\text { Official rate is pegged to the SDR. On June } 1976 \text { the } \\
\text { parallel market premia hit } 255 \%\end{array}$ \\
\hline January $20,1979-$ August 1983 & Managed floating/Parallel market & \\
\hline September 1983-May 1985 & $\begin{array}{l}\text { Freely falling/Managed } \\
\text { floating/Parallel market }\end{array}$ & $\begin{array}{l}\text { There are multiple exchange rates. Through } 1988 \text { parallel } \\
\text { premia are over } 100 \% \text { without exception. }\end{array}$ \\
\hline June 1985-August 1991 & $\begin{array}{l}\text { Managed floating market/Parallel } \\
\text { market }\end{array}$ & $\begin{array}{l}\text { In the run-up to the large devaluation in early } 1986 \text { the } \\
\text { parallel premia was over } 300 \% \text {. }\end{array}$ \\
\hline September, 1991-August 3, 1993 & $\begin{array}{l}\text { Freely falling/Managed } \\
\text { floating/Parallel market }\end{array}$ & $\begin{array}{l}\text { On August 3, } 1993 \text { official and bureau rates were unified. } \\
\text { Since that time (through December 1998), parallel market } \\
\text { premium have been in single digits. }\end{array}$ \\
\hline January 1994-March 1996 & $\begin{array}{l}\text { De facto crawling band around US } \\
\text { Dollar }\end{array}$ & There are multiple rates through 1995 . Band width $+/-5 \%$. \\
\hline May 1995-December 2001 & $\begin{array}{l}\text { De facto crawling band around US } \\
\text { Dollar }\end{array}$ & Band width $+/-2 \%$. \\
\hline
\end{tabular}

Notes: On October 29, 1964 Tanganyika and Zanzibar were renamed Tanzania.

Thailand

\begin{tabular}{|l|l|l|}
\hline Date & $\begin{array}{l}\text { Classification: } \\
\text { Primary/Secondary/Tertiary }\end{array}$ & Comments \\
\hline April 15, 1928-May 11, 1932 & Peg & Gold, Baht replaces Tical \\
\hline May 11, 1932-September 7, 1939 & Peg to Pound Sterling & \\
\hline 1939-April 22, 1942 & Exchange controls & \\
\hline April 22, 1942-May 1, 1946 & Peg to Yen & Parallel market premia over 100\% prevail through 1949. \\
\hline May 1, 1946-1947 & Peg to Pound Sterling & $\begin{array}{l}\text { There are multiple exchange rates. Parallel market premia } \\
\text { oscillate in the 50-90\% range. }\end{array}$ \\
\hline 1947-January 1, 1956 & $\begin{array}{l}\text { De facto band around US } \\
\text { Dollar/Parallel market }\end{array}$ & $\begin{array}{l}\text { Band width is +/-2\%. Exchange rates were unified. Parallel } \\
\text { market premia drop to single digits. }\end{array}$ \\
\hline January 1, 1956-October 20, 1963 & De facto band around US Dollar & \\
\hline October 20, 1963-March 8, 1978 & Peg to US Dollar & The Baht is officially pegged to a basket of currencies. \\
\hline March 8, 1978-July 1997 & De facto peg to US Dollar & \\
\hline July 1997-January 1998 & Freely falling/Freely floating & \\
\hline January 1998-December 2001 & Managed floating & \\
\hline
\end{tabular}

Notes: Reference currency is the US Dollar.

Togo

Central Bank of West African States: Benin, Burkina Faso, Cote D'Ivoire, Guinea-Bissau, Mali, Niger, Senegal, and Togo ${ }^{1}$

\begin{tabular}{|l|l|l|}
\hline Date & $\begin{array}{l}\text { Classification: } \\
\text { Primary/Secondary/Tertiary }\end{array}$ & Comments \\
\hline June 29, 1901 & Peg to French Franc & $\begin{array}{l}\text { Banque de l'Afrique Occidentale is allowed to issue bank } \\
\text { notes. }\end{array}$ \\
\hline September 9, 1939 & $\begin{array}{l}\text { Exchange controls are introduced in } \\
\text { Franc zone }\end{array}$ & \\
\hline February 2, 1943- December 26. 1945 & Peg to US Dollar and Pound Sterling & On December 1942 incorporated in the Sterling Area \\
\hline December 26. 1945- May 12, 1962 & Peg to French Franc & Return to Franc Zone. The CFA Franc is introduced. \\
\hline September 20, 1949- & Peg to French Franc & Creation of the Central Bank of West African States \\
\hline May 12, 1962-September 9, 1971 & Peg to French Franc & Low parallel market premium \\
\hline September 9, 1971-March 21, 1974 & $\begin{array}{l}\text { De facto peg to French Franc/ Dual } \\
\text { Market }\end{array}$ & \\
\hline March 21, 1974-December 1993 & Peg to French Franc & One 100\% devaluation. \\
\hline January 1994-December 1994 & Peg to French Franc/Freely falling & \\
\hline January 1995-January 1, 1999 & Peg to French Franc & \\
\hline January 1, 1999-December 2001 & Peg to Euro & \\
\hline
\end{tabular}

${ }^{1}$ Mali joined the currency arrangement at a later date.

Note: Reference currencies are the French Franc and the Euro 
Tunisia

\begin{tabular}{|c|c|c|}
\hline Date & $\begin{array}{l}\text { Classification: } \\
\text { Primary/Secondary/Tertiary }\end{array}$ & Comments \\
\hline May 2, 1929-September 6, 1939 & Peg to French Franc & Tunisian Franc on gold standard \\
\hline September 6, 1939-June 1943 & Capital controls & \\
\hline June 1943-December 6, 1944 & Peg to US Dollar and Pound Sterling & \\
\hline December 6, 1944-November 1945 & Peg to French Franc & Return to Franc-Zone \\
\hline December 1945-January 26, 1948 & Peg to French Franc/Freely falling & \\
\hline January 26, 1948-March 1949 & $\begin{array}{l}\text { Freely falling/ De facto band around } \\
\text { French Franc }\end{array}$ & \\
\hline April 1949-November 1, 1958 & De facto band around French Franc & Band width is $+/-2 \%$. There are multiple exchange rates. \\
\hline November 1, 1958-March 21, 1974 & Peg to French Franc & $\begin{array}{l}\text { Tunisian Dinar replaces Tunisian Franc. Active parallel } \\
\text { market In May } 1962 \text { parallel market premia peaks at } 257 \% \text {. } \\
\text { It remains in three digits through mid-1963 and oscillates } \\
\text { in the } 20-90 \% \text { range through } 1972 \text {. }\end{array}$ \\
\hline March 21, 1974- January 1, 1999 & $\begin{array}{l}\text { De facto crawling band around French } \\
\text { Franc }\end{array}$ & $\begin{array}{l}\text { Band width is }+/-2 \% \text {. Since } 1992 \text { parallel market premia is } \\
\text { in single digits. }\end{array}$ \\
\hline January 1, 1999-December 2001 & De facto crawling band around Euro & Band width is $+/-2 \%$. \\
\hline
\end{tabular}

Note: Reference currencies are the French Franc and the Euro

Turkey

\begin{tabular}{|c|c|c|}
\hline Date & $\begin{array}{l}\text { Classification: } \\
\text { Primary/Secondary/Tertiary }\end{array}$ & Comments \\
\hline September 1930-August 1931 & Peg to Pound Sterling & \\
\hline September 1931-September 26, 1936 & Peg to French Franc & \\
\hline $\begin{array}{l}\text { September 26, 1936-November 28, } \\
1939\end{array}$ & Peg to Pound Sterling & \\
\hline November 28, 1939-February 1941 & Parallel market & There are multiple exchange rates. \\
\hline March 1941-August 1943 & Freely falling/Parallel market & There are multiple exchange rates. \\
\hline September 1943-September 9, 1946 & Parallel market & There are multiple exchange rates. \\
\hline September 9, 1946-September 3, 1953 & $\begin{array}{l}\text { De facto crawling band around US } \\
\text { Dollar/Parallel market }\end{array}$ & $\begin{array}{l}\text { The official rate is pegged to the US Dollar. Band width is } \\
+/-5 \% \text {. }\end{array}$ \\
\hline September 3, 1953-August 20, 1960 & Managed floating/Parallel market & $\begin{array}{l}\text { There are multiple exchange rates. Parallel market premia } \\
\text { is consistently in three digits and peaks at } 537 \% \text { on July } \\
1958 \text {. }\end{array}$ \\
\hline August 20, 1960-June 6, 1961 & Peg to US Dollar & \\
\hline June $6,1961-$ August 9, 1970 & $\begin{array}{l}\text { De facto crawling band around US } \\
\text { Dollar/Dual Rates }\end{array}$ & $\begin{array}{l}\text { Band width is }+/-5 \% \text {. Parallel market premia oscillates in } \\
\text { the } 30-60 \% \text { range. }\end{array}$ \\
\hline August 9, 1970-December 22, 1971 & Peg to US Dollar & \\
\hline December 22, 1971-August, 1976 & $\begin{array}{l}\text { De facto crawling band around US } \\
\text { Dollar/Parallel market }\end{array}$ & $\begin{array}{l}\text { There are multiple exchange rates. Band width is }+/-5 \% \text {. } \\
\text { The official rates are pegged but there are frequent } \\
\text { adjustments. There is an official horizontal } 4.5 \% \text { band. }\end{array}$ \\
\hline September 1976-March, 1981 & $\begin{array}{l}\text { Freely falling/De facto crawling band } \\
\text { around US Dollar/Parallel market }\end{array}$ & $\begin{array}{l}\text { There are multiple exchange rates. Band width is }+/-5 \% \text {. } \\
\text { The official rates are pegged but there are frequent } \\
\text { adjustments. }\end{array}$ \\
\hline April 1981-March 22, 1983 & Managed floating/Parallel market & $\begin{array}{l}\text { There are multiple exchange rates. On May 1, } 1981 \text { the lira } \\
\text { was formally de-linked from the US Dollar. }\end{array}$ \\
\hline March 22, 1983-April 1984 & Managed floating & $\begin{array}{l}\text { Since } 1984 \text { the parallel market premia has largely remained } \\
\text { in single digits. }\end{array}$ \\
\hline May 1984-January 1998 & Freely falling/Managed floating & \\
\hline February 1998-January 1, 1999 & $\begin{array}{l}\text { Crawling band around DM/Freely } \\
\text { falling }\end{array}$ & $\begin{array}{l}\text { Band width is }+/-5 \% \text {. The crawling band is only detected } \\
\text { with the } 24-\text { month window. }\end{array}$ \\
\hline January 1, 1999-January 2001 & $\begin{array}{l}\text { Crawling band around Euro/Freely } \\
\text { falling }\end{array}$ & Band width is $+/-5 \%$ \\
\hline February-2001October 2001 & Freely falling/Freely floating & \\
\hline
\end{tabular}

Notes: Reference currencies are the US Dollar, the DM, and the Euro.

Turkmenistan

\begin{tabular}{|l|l|l|}
\hline Date & $\begin{array}{l}\text { Classification: } \\
\text { Primary/Secondary/Tertiary }\end{array}$ & Comments \\
\hline January 1993-October 1997 & Freely falling/Dual market & $\begin{array}{l}\text { On November 1, 1993 the Manat replaced the Russian } \\
\text { Ruble as legal tender. There is no price data before this } \\
\text { date. There are multiple exchange rates }\end{array}$ \\
\hline November 1997-December 2001 & Dual Market & $\begin{array}{l}\text { There was a short-lived unification on April 20, 1998. } \\
\text { Since the introduction of the Manat the official rate has } \\
\text { been pegged to the US Dollar with periodic large } \\
\text { devaluations. }\end{array}$ \\
\hline
\end{tabular}


Notes: Reference currency is the US Dollar.

Uganda

\begin{tabular}{|c|c|c|}
\hline Date & $\begin{array}{l}\text { Classification: } \\
\text { Primary/Secondary/Tertiary }\end{array}$ & Comments \\
\hline January $1,1922-$ August 15,1966 & Peg to Pound Sterling/Currency union & $\begin{array}{l}\text { East African Shilling is introduced Uganda, Kenya, and } \\
\text { Tanzania form the East African Currency Area. }\end{array}$ \\
\hline August 15, 1966-October 11, 1971 & Peg to Pound Sterling/Currency union & Ugandan Shilling replaces the East African Shilling \\
\hline October 11, 1971-October 27, 1975 & Managed floating/Parallel market & $\begin{array}{l}\text { While the official rate is linked to the US Dollar, there is } \\
\text { an active parallel market. }\end{array}$ \\
\hline October 27, 1975-June 8, 1981 & Managed floating/Parallel market & $\begin{array}{l}\text { The Ugandan shilling is officially pegged to the SDR. On } \\
\text { July } 1977 \text { the East African Currency Area came to its end. } \\
\text { From } 1977 \text { onwards, the parallel market premium is } \\
\text { hovering close to } 1,000 \% \text {. On June } 1981 \text { the currency was } \\
\text { devalued by } 840 \% \text {. }\end{array}$ \\
\hline August 23, 1982-October 1983 & Freely floating/Dual Market & Officially the Shilling is linked to a basket of currencies. \\
\hline Novembert 1983-June 15, 1984 & $\begin{array}{l}\text { Freely falling/Freely floating/Dual } \\
\text { Market }\end{array}$ & \\
\hline June 15, 1984- May 28, 1986 & Freely falling/Freely floating & $\begin{array}{l}\text { The official rate is pegged to the US Dollar through May } \\
1985 \text {. In that month the parallel market premium reached } \\
2,109 \% \text {. }\end{array}$ \\
\hline May $28,1986-$ August 23,1986 & $\begin{array}{l}\text { Freely falling/Freely floating/Dual } \\
\text { Market }\end{array}$ & \\
\hline August 23, 1986- September 1989 & Peg to US Dollar/Freely falling & $\begin{array}{l}\text { Following a 329\% devaluation, on May 18, } 1987 \text { a currency } \\
\text { reform exchanged old shillings for the new shilling. }\end{array}$ \\
\hline October 1989-July 2, 1992 & $\begin{array}{l}\text { Freely falling/De facto crawling band } \\
\text { around US Dollar }\end{array}$ & $\begin{array}{l}\text { Band width is }+/-5 \% \text {. On April } 1987 \text { the parallel market } \\
\text { premium reached } 1,186 \% \text {. }\end{array}$ \\
\hline July 2, 1992-December, 1992 & $\begin{array}{l}\text { Freely falling/De facto crawling band } \\
\text { around US Dollar/Dual Market }\end{array}$ & Band width is $+/-5 \%$. \\
\hline January 1993-November 1,1993 & $\begin{array}{l}\text { De facto crawling band around US } \\
\text { Dollar/Dual Market }\end{array}$ & Band width is $+/-5 \%$. \\
\hline November 1, 1993-December 2001 & $\begin{array}{l}\text { De facto crawling band around US } \\
\text { Dollar }\end{array}$ & $\begin{array}{l}\text { Band width is }+/-5 \% \text {. Since } 1995 \text { parallel market premium } \\
\text { fell to the } 10-15 \% \text { range and into single digits since } 1996 \text {. }\end{array}$ \\
\hline
\end{tabular}

Notes: Reference currencies are US Dollar, Pound Sterling, and SDR.

Ukraine

\begin{tabular}{|c|c|c|}
\hline Date & $\begin{array}{l}\text { Classification: } \\
\text { Primary/Secondary/Tertiary }\end{array}$ & Comments \\
\hline January, 1991-October, 1996 & Freely falling/Dual Markets & There is no price data before this date. \\
\hline October 1996-September 4, 1998 & Dual Markets & \\
\hline September 4, 1998-November 1999 & $\begin{array}{l}\text { De facto crawling band around US } \\
\text { Dollar }\end{array}$ & $\begin{array}{l}\text { In September } 1998 \text { the Ukranian Hryvnia was devalued by } \\
51 \% \text { versus the US Dollar and markets were unified. There } \\
\text { is a pre-announced official horizontal band. }\end{array}$ \\
\hline February 21, 2000-December 2001 & De facto peg to US Dollar & $\begin{array}{l}\text { On February } 2000 \text { the central bank formally announced a } \\
\text { floating rate policy. }\end{array}$ \\
\hline
\end{tabular}

Notes: Reference currency is the US Dollar. 
United Kingdom

\begin{tabular}{|c|c|c|}
\hline Date & $\begin{array}{l}\text { Classification: } \\
\text { Primary/Secondary/Tertiary }\end{array}$ & Comments \\
\hline April 25, 1925-September 21, 1931 & Peg & Gold \\
\hline September 21, 1931- March 1940 & Managed floating & $\begin{array}{l}\text { On August 25, } 1939 \text { foreign exchange controls are } \\
\text { introduced. }\end{array}$ \\
\hline March 1940-July 1948 & $\begin{array}{l}\text { De facto band around US } \\
\text { Dollar/Parallel market }\end{array}$ & $\begin{array}{l}\text { Band width is }+/-5 \% \text {. There are multiple exchange rates. The } \\
\text { official rate is pegged to the US Dollar/Exchange controls } \\
\text { introduced on August } 25,1939 \text {. The Pound is only } \\
\text { convertible during July } 15 \text {-August } 21,1947 \text {. In February } \\
1946 \text { the parallel market premium peaked at } 97 \% \text {. }\end{array}$ \\
\hline August 1948-September 1950 & $\begin{array}{l}\text { De facto band around US } \\
\text { Dollar/Parallel market }\end{array}$ & $\begin{array}{l}\text { Band width is }+/-2 \% \text {. The official rate is pegged to the US } \\
\text { Dollar but there are multiple rates. Through August } 1949 \\
\text { parallel premium oscillates in the } 30-90 \% \text { range. }\end{array}$ \\
\hline September $1950-$ August 19,1970 & Peg to US Dollar/Dual Market & $\begin{array}{l}\text { Introduction of the Switch Pound. There are multiple rates. } \\
\text { The Switch pound was abolished on April 1967. The } \\
\text { Property Dollar was abolished }\end{array}$ \\
\hline August 19, 1970-June 23, 1972 & Peg to US Dollar/Dual Market & \\
\hline June $23,1972-$ October 8,1990 & Managed Floating & $\begin{array}{l}\text { Until the dissolution of the Sterling Area on October 24, } \\
1979 \text { and the dismantling of capital controls, the UK had a } \\
\text { dual rate system. }\end{array}$ \\
\hline October 8, 1990-September 12,1992 & Pre announced band around ECU/DM & Band width $+/-6 \%$. \\
\hline September 12, 1992-December 2001 & Managed floating & \\
\hline
\end{tabular}

Notes: Reference currencies are the US Dollar, the DM, the Euro, and the Yen.

United States

\begin{tabular}{|l|l|l|}
\hline Date & $\begin{array}{l}\text { Classification: } \\
\text { Primary/Secondary/Tertiary }\end{array}$ & Comments \\
\hline June 30, 1919-March 9, 1933 & Peg & Gold Standard \\
\hline March 9, 1933-January 31, 1934 & Capital controls & The US Dollar's convertibility into gold is suspended \\
\hline December 19, 1946-August 15,1971 & Peg & $\begin{array}{l}\text { Gold and SDR, same parity as 1934. On August 15, the } \\
\text { US notified the IMF it would no longer freely buy or sell } \\
\text { gold for the settlement of international transactions }\end{array}$ \\
\hline August 15, 1971- February 13, 1973 & Mini float & $\begin{array}{l}\text { On May 8, 1972 there is further devaluation versus gold } \\
\text { and other currencies }\end{array}$ \\
\hline February 13, 1973 February, 1978 & De facto moving band with the Yen & $\begin{array}{l}\text { Further devaluation versus gold and other currencies. Band } \\
\text { width +/- 2\%. }\end{array}$ \\
\hline February 1978-December 2001 & Freely floating & $\begin{array}{l}\text { On April 1, 1978 the law that required the par value of the } \\
\text { US Dollar in terms of gold and SDRs is repealed. }\end{array}$ \\
\hline
\end{tabular}

Notes: Reference currencies are the Pound Sterling, the DM, the Euro, and the Yen. 


\begin{tabular}{|c|c|c|}
\hline \multicolumn{3}{|l|}{ Uruguay } \\
\hline Date & $\begin{array}{l}\text { Classification: } \\
\text { Primary/Secondary/Tertiary }\end{array}$ & Comments \\
\hline 1931-January 10, 1941 & Peg to Pound Sterling & On December 1929 the gold standard was suspended. \\
\hline January 10, 1941-July 1944 & Peg to US Dollar & \\
\hline July 1944-July 1947 & $\begin{array}{l}\text { Dual Market/De facto crawling band } \\
\text { around US Dollar }\end{array}$ & \\
\hline July 1947-September 1948 & Peg to US Dollar & \\
\hline September 1948-May 1958 & $\begin{array}{l}\text { De facto crawling band around US } \\
\text { Dollar/parallel market }\end{array}$ & There are multiple exchange rates. Band width is $+/-5 \%$. \\
\hline June 1958-December 17, 1959 & $\begin{array}{l}\text { Freely falling/De facto crawling band } \\
\text { around US Dollar/Parallel market }\end{array}$ & There are multiple exchange rates. Band width is $+/-5 \%$. \\
\hline December 17, 1959-October 1960 & Freely falling/Managed floating & $\begin{array}{l}\text { Exchange and monetary reform. Exchange rates were } \\
\text { unified and fluctuating rate applied to all transactions. }\end{array}$ \\
\hline November 1960-November 1962 & Managed floating & \\
\hline December 1962-July 19, 1963 & Freely falling/Managed floating & \\
\hline July $19,1963-$ July 1965 & $\begin{array}{l}\text { Freely falling/De facto crawling band } \\
\text { around US Dollar/Dual Markets }\end{array}$ & Band width is $+/-5 \%$. \\
\hline August 1965-May 1968 & $\begin{array}{l}\text { Freely falling/Managed floating/Dual } \\
\text { Markets }\end{array}$ & $\begin{array}{l}\text { The official rate is pegged to the US Dollar there are } \\
\text { periodic large devaluations. In October } 1965 \text { the parallel } \\
\text { market premium reached } 196 \% \text {. The official rate was } \\
\text { devalued by } 150 \% \text { that same month. }\end{array}$ \\
\hline June 1968-January 1969 & Peg to US Dollar/Freely falling & $\begin{array}{l}\text { There is an inflation stabilization plan-while the official } \\
\text { rate is tied to the US Dollar parallel market activity } \\
\text { remains considerable in some months. }\end{array}$ \\
\hline February 1969-December 1970 & Peg to US Dollars & \\
\hline January $1971-$ April 26, 1971 & $\begin{array}{l}\text { Freely falling/Managed floating/Dual } \\
\text { Markets }\end{array}$ & There are multiple exchange rates. \\
\hline April 26, 1971-November 1974 & $\begin{array}{l}\text { Freely falling/Managed } \\
\text { floating/Parallel market }\end{array}$ & $\begin{array}{l}\text { On November } 1971 \text { the free market premium reached } 182 \\
\% \text { - on march } 1972 \text { the official rate was devalued by } 100 \% \text {. }\end{array}$ \\
\hline December 1974-October 17,1978 & $\begin{array}{l}\text { Freely falling/De facto crawling band } \\
\text { around US Dollar/Parallel market }\end{array}$ & $\begin{array}{l}\text { There are multiple exchange rates. Band width is }+/-5 \% \text {. In } \\
\text { October } 1974\end{array}$ \\
\hline October 17, 1978-November 26, 1982 & $\begin{array}{l}\text { Pre announced crawling peg to US } \\
\text { Dollar, the Tablita/Freely falling }\end{array}$ & \\
\hline November 26, 1982-December 1985 & Freely falling/Freely floating & \\
\hline January 1986-December 1990 & Freely falling/Freely floating & There are multiple exchange rates. \\
\hline December 1990-December 1, 1991 & $\begin{array}{l}\text { Pre announced crawling band/Freely } \\
\text { falling }\end{array}$ & Official and de facto band $+/-2 \%$ \\
\hline December 1, 1991-November 2, 1992 & $\begin{array}{l}\text { Freely falling/Pre announced crawling } \\
\text { band }\end{array}$ & Official $+/-4 \%$, de facto band $+/-2 \%$ \\
\hline November 2, 1992-September 1995 & Freely falling/de facto crawling band & $\begin{array}{l}\text { Official }+/-7 \% \text {, de facto band }+/-2 \% \text {. Since } 1994 \text { the } \\
\text { parallel market premium has been in single digits. }\end{array}$ \\
\hline October 1995-December 1998 & De facto crawling band & Official $+/-7 \%$, de facto band $+/-2 \%$. \\
\hline December, 1999-December 2001 & De facto crawling band & $\begin{array}{l}\text { Official }+/-3 \% \text {, de facto band }+/-2 \% \text {. On January } 4,2002 \\
\text { the band was widened to }+/-6 \% \text { and the pace of } \\
\text { depreciation was accelerated. }\end{array}$ \\
\hline
\end{tabular}




\begin{tabular}{|c|c|c|}
\hline Date & $\begin{array}{l}\text { Classification: } \\
\text { Primary/Secondary/Tertiary }\end{array}$ & Comments \\
\hline August 1934-July 23, 1941 & Peg to US Dollar & Foreign exchange controls introduced \\
\hline July 23, 1941-July 1, 1976 & Peg to US Dollar & There are multiple exchange rates. \\
\hline July 1, 1976-February 28,1983 & Peg to US Dollar/ Dual Market & Up until lawe 1982 free market premia is in single digits. \\
\hline February 28, 1983-November 1986 & Managed floating/Parallel market & $\begin{array}{l}\text { There are multiple exchange rates officially linked to the US } \\
\text { Dollar. In July } 1983 \text { parallel market premia rose to } 319 \% \text {. }\end{array}$ \\
\hline December 1986-March 13, 1989 & Freely falling/Managed floating & $\begin{array}{l}\text { There are multiple exchange rates. Parallel market premia } \\
\text { are consistently above } 100 \% \text {. }\end{array}$ \\
\hline March 13, 1989-March 1990 & Freely falling/Managed floating & \\
\hline April 1990-September 1992 & Managed floating & \\
\hline October 1992-May 4, 1994 & Freely falling/Managed floating & \\
\hline May 4, 1994-April 22, 1996 & $\begin{array}{l}\text { Freely falling/Dual market/De facto } \\
\text { crawling band around US Dollar }\end{array}$ & $\begin{array}{l}\text { Band width is }+/-5 \% \text {. Parallel market premium jumped to } \\
100 \% \text { ion November } 1995 \text {. }\end{array}$ \\
\hline April 22, 1996-July 8, 1996 & $\begin{array}{l}\text { Freely falling/De facto } \\
\text { crawling band around US Dollar }\end{array}$ & Band width is $+/-5 \%$. \\
\hline July 8, 1996-July 1997 & $\begin{array}{l}\text { Pre announced crawling band around } \\
\text { US Dollar/Freely falling }\end{array}$ & $\begin{array}{l}\text { Official band is }+/-7.5 \% \text {, de facto band is }+/-2 \% \text {. Parallel } \\
\text { market premium declines to single digits during this period. }\end{array}$ \\
\hline August 1997-December 2001 & $\begin{array}{l}\text { Pre announced crawling band around } \\
\text { US Dollar }\end{array}$ & Official band is $+/-7.5 \%$, de facto band is $+/-2 \%$. \\
\hline
\end{tabular}

Notes: reference currency is the US Dollar

\section{Zambia}

\section{Date}

$1891-1940$

1940- April 1, 1956

April 1, 1956- November 16, 1964

November 16, 1964- January 16, 1968

January 16, 1968-December 6, 1971

December 6, 1971-July 9, 1976

July 9, 1976-July 1983

October 1985-March 17, 1987

March 17, 1987-May 4, 1987

May 2, 1987-November 9, 1988

November 9, 1988-February 19, 1990

February 19, 1990-December 1998

January 1999-August 2001

August 2001-December 2001

Notes: Zambia was formerly northern Rhodesia. Reference currencies are the South African Rand, the SDR, the Pound Sterling and the US

Dollar.

\section{Zimbabwe}

\section{Date}

March 7, 1980-June, 1983

July 1983-April 1991

May 1991-July 2, 1994

July 2, 1994-November 1997

November 1997-March 31, 1999

March 31, 1999-December, 2001

January 2000-August 1, 2000

August 1, 2000-December, 2001

Classification:

Primary/Secondary/Tertiary

De facto crawling band around US

Dollar
Classification:

Primary/Secondary/Tertiary

Exchange arrangement with no

Peg to Pound Sterling/Currency Board

Peg to Pound Sterling

Peg to Pound Sterling

anaged floating/Parallel market

Freely falling/Freely floating/Parallel market

Market

Freely falling/Freely floating/Parallel market

Freely falling/Freely floating/Parallel

Freely falling/Dual Market/Freely

floating

Freely falling/Freely floating

Freely floating

\section{Comments}

Pound Sterling

Southern Rhodesia Pound replaces British Pound

Rhodesia and Nyasaland Pound replaces Southern

Rhodesia Pound

Zambia Pound replaces Rhodesia and Nyasaland Pound.

Exchange controls are introduced.

Kwacha replaces Zambia Pound

Official rate is pegged to the US Dollar.

Multiple rates are introduced in 1979. Official rate is

pegged to SDR. Through 1979 parallel market premia is in three digits.

Official rate is pegged to US Dollar. In November 1988 the parallel market premium reached $974 \%$.

Official rate is pegged to SDR In May 1989 the parallel premium reached an all-time high of $1,222 \%$.

There was a short-lived unification in 1997.

Notes: Reference currencies are the South African Rand and the US Dollar. Zimbabwe was formerly part of Rhodesia. 